\title{
Ilgtspējīga attīstība un sociālās inovācijas
}

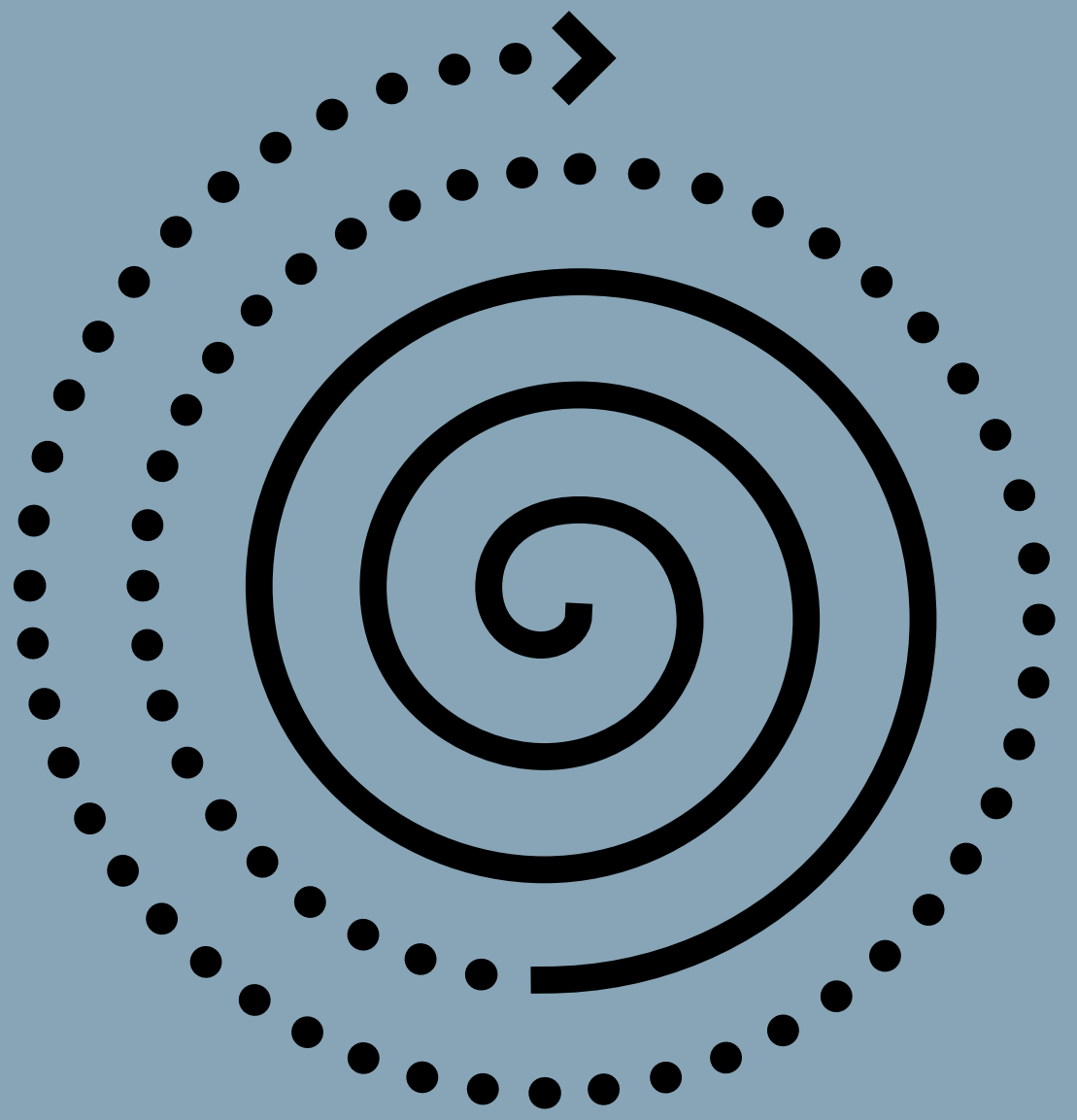

Zinātniskā redaktore

Dr. sc. soc. Baiba Bela 


\section{Ilgtspējīga attīstība un} sociālās inovācijas

Zinātniskā redaktore Dr. sc. soc. Baiba Bela 
IEVADS Ilgtspējìga attīstỉba, nabadzības un nevienlīdzības mazināšana un cienpilna dzive

\section{RECENZENTI:}

Dr. filoz. soc. darbā Signe Dobelniece, Latvijas Lauksaimniecības universitāte

Dr. sc. soc. Vladimirs Menšikovs, Daugavpils Universitāte

Kolektivā monogrāfija ir apstiprināta publicēšanai ar Latvijas Universitātes Sociālo zinātnu fakultātes Sociālo un politisko pētijumu institūta 02.03.2018. sēdes lēmumu (protokola Nr. SZF-V15.5/3).

\section{LITERĀRĀ REDAKTORE Gita Bērziṇ}

TULKOTĀJA Andra Damberga

Kolektīvā monogrāfija izstrādāta LU Sociālo zinātnu fakultātes Sociālo un politisko pētījumu institūtā ar Valsts pētījumu programmas «Inovācija un ilgtspējiga attīstība: Latvijas pēckrīzes procesi globālā kontekstā» (SUSTINNO) finansiālu atbalstu.

\section{SUSTINNO $\quad$ LATVIJAS}

ISBN 978-9934-18-306-5

1 ILGTSPĒ IIGAS ATTĪSTĪBAS TIESISKIE UN PĀRVALDES ASPEKTI

11 JĀNIS PLEPS Ilótspējigas attīstības konstitucionālā dimensija

1.2 ANITA KOVAḶEVSKA Sociāli atbildīgas valsts princips kā Latvijas Republikas valsts iekārtu raksturojošs princips

1.3 IVETA REINHOLDE Sociālās rīcībpolitikas pārvaldỉbas izaicinājumi un krizes mācības

1.4 MARTA TRIPĀNe Veselïbas stāvokḷa nevienlïdzỉba un veselïbas rīcībpolitika Latvijā

\section{CELĀ UZ CIENPILNU DZĪVI}

2.1 BaIBA BELA, JURIJS N NıKıŠıNS Ilgtspējas sociālā dimensija: vai virzāmies pretī labklājībai un cieņpilnai dzìvei?

2.2 BAIBA BELA Nabadzības strupceḷš: grūtību akumulācija un risinājumu meklējumi sieviešu pieredzes stāstos

\section{SOCIĀLĀS INOVĀCIJAS LABĀKAI DZİVEI}

3.1 ANETE VINGRE Sociālās inovācijas: valsts loma to sekmēšanā pasaulē un Latvijā

3.2 VINETA SILKĀNe Pavirzišanas iespējas veicināt dalību vēža savlaicīgas atklāšanas programmā

3.3 GUNA SPURAVA, BAIBA HOLMA Bibliotekāra kā mediatora loma bērnu un jauniešu digitālās pratības veicināšanā

AUTORI

ENGLISH SU M MARY Sustainable development, reduction of poverty and inequality, and a decent life

AUTHORS 


\section{Ilgtspējīga attīstība, nabadzības un nevienlìdzības mazināšana un cienpilna dzive}

Ilgtspējigas attīstības ideja tās mūsdienu formulējumā radās 20.gadsimta 8o.gados un kḷuva plaši pazīstama saistībā ar ziṇojumu «Mūsu kopīgā nākotne», ko radỉja ANO un 1987. gadā publicēja Norvêgijas kādreizējās premjerministres Grū Hārlemas Bruntlandes vadītā Pasaules Apkārtējās vides un attīstības komisija (WCED, 1987). Jau komisijas ziņojumā ilgtspējiga attīstība tika saistìta ne tikai ar resursiem un apkārtējo vidi, bet arī ar cilvēku spēju celt sabiedrības locekḷu labklājību un dzives kvalitāti, uzlabot piekluves iespējas izglitīibai un veselïbas aizsardzībai, garantēt minimālos drošības standartus un cilvēktiesību ievērošanu. 1995. gadā Apvienoto Nāciju Organizācijas rìkotajā Pasaules samitā par sociālo attīstību tika uzsvērts, ka attīstỉbas centrā jābūt cilvēkam un labklājībai, kas pieejama visiem (United Nations, 1995). Šādā skatijumā nabadzība un nevienlīdzība ir būtiskākie faktori, kas cilvēkiem liedz būt brīviem no bada, analfabētisma un slimībām, no kurām ir iespējams izvairīties. Visbūtiskāk nabadzība un nevienlīdzỉba ierobežo pozitīvo brīvību - brīvìbu dzivot ar cieņu un brīibu izvirzit un īstenot sev svarīgus mērḳus. Turklāt uz cilvēku brīvību vērsta attīstība ir îstenojama tādā veidā, lai tagadnes paaudžu dzīves apstākḷu uzlabošanās nenotiktu uz nākotnes paaudžu rēkina. Tā ir pieeja, kas iestājas par katra cilvēka tiesībām uz cieņpilnu dzìvi, ko nodrošina tāda ekonomiskā attīstība, kas ir lỉdzsvarā ar mūsu planētas ekosistēmu. Tā balstās uz atzinu, ka mēs dzìvojam pasaulē, kura klūst arvien sarežǵitāka un kurā lokālas un nacionālas norises arvien jūtamāk ir iesaistìtas globālo norišu tìklos.

Mūsdienu zinātnē un politikā arvien izteiktāka kḷūst spriedze starp vides un sabiedrības vajadzībām, kā arī nevienprātìba izpratnē par to, ko nozìmē attīstība, ilgtspēja un pamatnosacỉjumi cieṇpilnai dzivei visiem. Pasaules vadošie ilgtspējiggas attīstỉbas pētnieki uzdod divus loti būtiskus jautājumus - kā cilvēku vēlmi dzivvot labāk sabalansēt ar planētas ekosistēmas robežām un kā veidot taisnigāâku sabiedrību, kura mazina nevienlīdzību un kurā katram ir iespēja īstenot sev svarīgus mērḳus tā, lai neapdraudētu nākamo paaudžu iespējas isstenot vinu mērḳus (United Nations Development Programme, 2011). Tas ir arī jautājums par mūsu atbildỉbu nākamo paaudžu priekšā - vai mūsu mazmazbērniem arī būs laba dzīve un kāda tā būs, domājot gan par dabas resursiem un vidi, gan par sabiedrïbas uzbūvi un cilvēku savstarpējām attiecībām, kādas atstāsim mantojumā nākamajām paaudzēm. Apvienoto Nāciju Organizācija un ar to saistītie pētnieki pašlaik ir visspēcīgākie lobiji idejai, ka «tautas attīstība ietver tādu cilvēka brīvỉbu paplašināšanos kā brīvỉba dzìvot ilgu, veselīgu un radošu dzivi, sasniegt mērkus, kurus cilvēkiem ir iemesls uzlūkot par vērtīgiem, un aktīvi iesaistīties taisnigas un ilğtspējiggas attīstības veidošanā uz mūsu kopīgās planētas» (United Nations Development Programme, 2010, p. 2). Patlaban dominējošā pieeja, kas nosaka arì Latvijas politisko darba kārtỉbu un zinātnes pamatievirzi, ir balstìta uz 
pārliecību, ka ir iespējama ekonomiska izaugssme, kas nes labklājỉbu visiem un var tikt sabalansēta ar vides aizsardzỉbu un planētas ekosistēmu kapacitāti. Reizē arvien plašāk ilgtspējīgas attīstības pētnieku vidū nostiprinās atzinna, ka Rietumu attīstības modelis nav universāla izmēra T krekls, kas der visiem (Buch-Hansen \& Lauridsen, 2012). Tas pat nav ideāls, uz ko tiekties, kaut arī Pasaules Banka un Ekonomiskās attīstības un sadarbỉbas organizācija (OECD) joprojām Rietumvalstu dzīvesveidu un ekonomiskās attīstỉbas rādītājus lieto kā attīstības mērauklu (Banerjee, 2003).

L,oti nopietna pretruna un problēma slēpjas apstāklī, ka turpmākam iedzīvotāju labklājības kāpumam un valstu ekonomiskai izaugsmei ir nepieciešams kāpināt ražošanu un attiecīgi arī patērinu. Ekoloğiskās pēdas idejas izstrādātāji norāda, ka pašreizējā ražošanas attīstības pakāpe un zemeslodes iedzivotāju dzivesveids 1,7 reizes pārsniedz mūsu planētas ekosistēmas spēju šādu dzivesveidu uzturēt, bet 2030. gadā ekosistēmas iespēju robežas tiks pārsniegtas jau divas reizes (Ecological Footprint, n. d.). Te gan jāatzīmē, ka pastāv būtiskas globālas atšḳirības pieejā resursiem un to izmantošanā2013. gadā pasaulē vidēji ekoloğiskā pēda bija 1,82 ha, Āfrikā tikai o,82 ha, Eiropā-2,85 ha, bet Ziemelamerikā-5,05 ha (Ecological Footprint, n.d.). Lidz ar to jau tagad ir skaidrs, ka vienigi stingrākas vides aizsardzības prasības nav risinājums. Daudzi pētnieki uzskata, ka vārdu savienojums «ilgtspējīga attīstìba» apzīmē neiespējamu procesu, jo klimata pārmainas, dabas daudzveidības strauja samazināšanās, neatjaunojamo resursu izsmelšana, kā arī pieaugoša nevienlïdzìba liecina par ko citu -ir jāmaina dzìvesveids, transformējot kā ražošanu, tā patēriņu (Kallis, Demaria, \& D’Alisa, 2015). Jaunāko teoriju un vides aktīvistu kustību piedāvātiem pamatjēdzieniem vēl nav pat tulkojuma latviešu valodā-degrowth theory un degrowth movement varētu saukt par «izaugsmes samazināšanas teoriju» un «izaugsmes mazināšanas kustỉbu». Tās aizstāv radikālu dzīvesveida vienkāršošanu un atteikšanos no kapitālisma ekonomikas tās pašreizējā veidolā. Rūpes, dalīšanās, kopigga resursu apsaimniekošana, ienākumu zemākā sliekšņa un griestu noteikšana - tie ir tikai daži atslēgvārdi, kas raksturo nepieciešamo sistēmas transformāciju. Maksimāla peḷna un pārmērīgs patēriṇš kā ilgots stāvoklis ir izrādỉjušies maldinoši «ideāli», kas dažiem ir nesuši izšḳērdīgu dzivesveidu, bet citiem, kuru diemžēl ir vairākums, - trūkumu un postu. Pat vadošie pasaules ekonomisti beidzot runā par to, ka pašreizējā globālā finanšu sistēma un kapitālisms tā tagadējā formā ir radījuši aizvien nevienlīdzīgāku sabiedrību, kas ḷāvusi materiālos resursus sakoncentrēt šauru grupu rokās (Stiglitz, 2012).

Latvija ir neatkarīga valsts jau vairāk nekā divdesmit piecus gadus. Šajā laikā ir nostiprinātas nozimīgas brīivibas - runas brīìiba, pulcēšanās briviiba, pārvietošanās brīvība un citas. Mūsu ikdienas materiālā labklājība ir būtiski citāda nekā 9o. gadu sākumā. Padomju laika preču deficīts pastāv tikai stāstos, atceroties sviesta rindas, cukura rindas, šnabja talonus vai prieku nopirkt tualetes papīru. Jaunākā paaudze ir augusi Latvijā, kur nevajag atḷauju, lai aizbrauktu uz Kolkas ragu, vai vīzu celojumam uz Franciju, un tā nezina, ko nozimē tukši veikalu plaukti. Tajā pašā laikā ir tendence uzmanības priekšplānā izvirzìt nevis sasniegto, bet nesasniegto. Patiešām, statistikas dati liecina, ka Eiropas Savienības mērogā mūsu algas un pensijas ir zemākas, ienākumu nevienlīdzība lielāka, sociālais budžets un veselības nozares budžets (procentpunktos no IKP) atpaliek no Eiropas Savienības vidējā. Veikalu plaukti gan ir pilni, bet ne visi var atlauties nopirkt pat nepieciešamo. Patērina sabiedrības rūpnieciskās mākslas darbi luksusa preču veikalos spilgti atgādina par patērētāju vairuma pirktspējas deficìtu. Raugoties uz ikdienas dzives standartu Dānijā, Vācijā vai İrijā, neapšaubāmi rodas izjūta, ka mēs joprojām atpaliekam un neesam nokḷuvuši tur, kur «kaut pastalās, bet brīvi» gribējām nokḷūt. Sabiedrības apziṇā joprojām dominē pārliecība, ka nepieciešams «nokert Rietumus». Radikālās idejas par izaugsmes samazināšanu un patērina ierobežošanu kā vienīgo iespējamo atbildīgo rīcibu škiet pāragras Latvijā, kur līdzīgi kā daudzās valstīs, kuras cenšas noḳert Rietumus, attieksmi var raksturot ar metaforu: «Hei, jums bija ballite, bet mums tiks tikai pağiras!?!» Kaut arī globālajā politiskajā darba kārtībā zinātnieku un vides aktīvistu radikāāākās idejas vēl ir jaunas, loti iespējams, tuvākajās desmitgadēs tās pilnībā mainīs izpratni par vēlamiem rīcības scenārijiem un politiskajām nostādnēm.

Valsts pētījumu programmas «Inovācija un ilgtspējīga attīstība: Latvijas pēckrīzes procesi globālā kontekstā»(SUSTINNO) projekta «Ilgtspējīgas attīstības sociālā dimensija un sociālās inovācijas» pētnieku komanda pētija tieši ilgstspējigas attīstības sociālos jautājumus, kamēr ekonomisko un vides dimensiju pētija kolēgói citos SUSTINNo projektos. N̦emot vērā 2008.-2009. gada ekonomiskās krīzes dziḷumu un atziṇu, ka sociālajos jautājumos križu sekas ir jūtamas ilgāk nekā ekonomiskajos (Brigsa et al., 2014), pētnieku komandas mērḳis bija vēl šaurāks - pētìt tieši pēckrīzes attīstỉbas trajektorijas. Kā zinātnieki mēs piedāvājam raudzìties uz Latvijas ekonomiskās un sociālās attīstības procesiem no cita skatu punkta - no ilgtspējīgas attīstības perspektīvas. Projekta noslēguma kolektīvajā monogrāfijā iepazīstināsim ar galvenajiem pētijuma rezultātiem. Ievadā vispirms tiks raksturotas idejas par ilgtspējīgu attīstību, kas veido pētỉjuma konceptuālo pamatojumu, un pēc tam apskatìta nodalu struktūra, kas veidota ap trim lielajiem pētỉjuma jautājumiem, proti, kāds ir juridiskais ietvars un pārvaldes efektivitāte ilgtspējiggas attīstības nodrošināšanai, kā veicas ar ilgtspējigas sociālās attīstības galveno bremzētāju - nabadzības un nevienlīdzības mazināšanu - un kādas ir sociālo inovāciju iespējas risināt jaunus attīstības izaicinājumus un sociālas problēmas.

Tiesības uz cienpilnu dzivi, kas jānodrošina ilgtspējīgai attīstībai, ir būtiska grāmatas caurviju tēma. Gan starptautiski, gan Latvijā plašāk zināma 
ANO Vides un attīstỉbas konferences zinojumā «Mūsu kopịgā nākotne» formulētā definīcija: ilgtspējiga attīstība ir tāda attīstība, kurā cilvēku pašreizējās vajadzības tiek apmierinātas, neierobežojot nākamo paaudžu iespējas apmierināt vinu vajadzỉbas (WCED, 1987). Tā kā pētỉjumā ievērojām jaunāko pieeju, kas priekšplānā izvirza labklājības un brīvibas ideju, ìsi iepazistināšu ar argumentiem, kāpēc fokuss uz vajadzỉbu apmierināšanu jaunajā tūkstošgadē tiek uzskatîts par nepietiekamu. Izcilais ekonomists Amartija Sens (Amartya Sen) piedāvā skatīities uz attīstību kā uz cilvēka spēju un brīvību stiprināšanu, nevis vienkārši kā vajadzību apmierināšanu (Sen, 2001, 2013). Viṇš uzskata, ka cilvēkiem ir būtiski nevis koncentrēties tikai uz vajadzībām (jo vajadzỉbas cilvēkiem ir līdzīgas kā visām citām dzīvajām būtnēm), bet svarīga ir iespēja brīvi izlemt, ko vini vēlas (ieskaitot to, kuras vajadzības apmierināt), un dzīvot tādā veidā, kā vēlas (neatkarīgi no tā, vai izraudzìtais dzivesveids tiek uzskatîts par vajadzỉbu). Brīvības perspektivvas ieklaušana ilgtspējīgas attīstības definēšanā ir radījusi vispārīgas sekas - mēs redzam cilvēkus nevis vienkārši kā būtnes, kurām ir vajadzības, bet pirmkārt kā cilvēkus, kuru brīvibai ir nozīme un kuri paši var izlemt, kā identificēt dažādās vajadzības un noteikt to prioritātes. Jāuzsver, ka šādā skatijumā demokrātija iegūst vēl dziḷāku pamatojumu - diskusiju brīiỉba un politiskās līdzdalības brīvỉba ir ḷoti būtiskas, lai varētu runāt par demokrātisku attīstỉbu, nevis «no augšas diktētu» attīstỉbu. Vienošanās par sabiedrības mērkiem un vērtībām, prioritārajām vajadzībām, pat patēriṇa uzvedỉbu ir jābalsta uz publisko diskusiju. 2015. gadā ANO pieṇemtā rezolūcija «Mūsu pasaules pārveidošana: Ilgtspējīgas attīstības programma 2030. gadam» un ilgtspējigas attīstības mērki ir balstīti uz priekšstatiem par ieklaujošu attīstību, kas vērsta uz cilvēka brīvību paplašināšanu (United Nations, 2015).

SUSTINNO pētijuma mugurkaulu veido pienēemums par to, ka cilvēkiem ir tiesības dzīvot ilğu, veselīgu un radošu dzivi, isstenot sev svarīgus mērḳus, un šo mērḳu îstenošana nedrīkstētu ierobežot nākamo paaudžu iespējas izvirzìt un îstenot tām svarīgus mērḳus. Analizējot pašreizējos procesus Latvijas sabiedrībā, grāmata veidota kā platforma tālākai publiskai diskusijai par vērtībām, kas balsta mūsu valsts attīstību un tās virzību pretī nospraustajiem attīstības mērḳiem. Meklēsim atbildes uz pētijumā izvirzītajiem jautājumiem - kādas ir Latvijas pēckrīzes sociālās problēmas un to ietekme uz ilgtspējīgu sociālo un reg̛ionālo attīstību, vērtēsim sociālo problēmu pārvarēšanas iespējas, kā arī analizēsim tiesiskā ietvara noteiktos pienākumus ilgtspējigas attīstības nodrošināšanai un to, vai pārvaldes sistēma spēj efektivi risināt sociālās problēmas.

Kolektivās monogrāfijas pirmā dą̣a «Ilgtspējigas attīstības tiesiskie un pārvaldes aspekti» aplūko tiesiskā ietvara noteiktos pienākumus ilgtspējigigas attīstības nodrošināšanai un pārvaldes sistēmas spēju efektīvi risi-

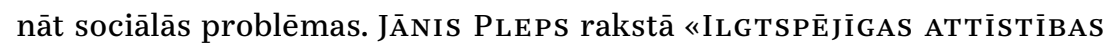

KONSTITUCIONĀLĀ DIMENSIJA» pievērsies jautājumam, vai Satversmē ir ietverts pietiekams ilgtspējigas attīstības jautājumu regulējums un kāda veida rīcību šajā jomā Satversme paredz. Autors analizē ilgtspējīgas attīstības principa attīstību Latvijas konstitucionālajā iekārtā, kā arī aplūko Satversmes normas, kurās ir ietverti atseviški ilgtspējigas attīstības principa elementi. N̦emot vērā, ka ilgtspējīgas attīstības sociālajā dimensijā izšḳiroša loma ir tādiem principiem kā cilvēka cieṇa, taisnīgums, vienlīdzība un solidaritāte, tiek pievērsta uzmanība arī jautājumam par valsts sociālo atbildīgumu. ANITA KovAḶEVSKA rakstā «SOCIĀLI ATBILDİGAS VALSTS PRINCIPS KĀ LATVIJAS REPUBLIKAS VALSTS IEKĀRTU RAKSTUROJOŠS PRINCIPS» iepazistina ar sociāli atbildīgas valsts idejas vēsturisko attīstību pasaulē un Latvijā, dzilāk analizē sociāli atbildīgas valsts principa saturu (valsts pienākumu nodrošināt cilvēka cienīgas eksistences minimālos priekšnoteikumus; valsts pienākumu nodrošināt aizsardzību sociāla riska gadỉjumā; valsts pienākumu rūpēties par sociālo taisnīgumu un cilvēka saistỉbu ar sabiedrību), kā arī skaidro no šĩ principa izrietošos pienākumus un tiesības Latvijas Republikai. Jāatzīst, ka Latvijā izveidotais tiesiskais ietvars ilgtspējigas un sociāli atbildīgas attīstības iedzīvināšanai neliek nekādus škēršlus, tāpēc iespējams diskutēt par izpratnes, zināšanu vai gribas trūkumu atbilstoši rīkoties. Tālāk pētỉjumā pievērsta uzmanība attīstības plānošanas sistēmas darbỉbas novērtējumam, kas varētu snieğt būtiskas atbildes uz jautājumu, kāpēc attīstìba buksē, par spîti labvēlīgam juridiskajam nodrošinājumam un plašam klāstam dažāda līmeṇa attīstības stratēgiju. IVETA REINHOLDE rakstā «SOCIĀLĀS RİCīBPoLITIKAS PĀRVALDİBAS IZAICINĀJUMI UN KRİZES MĀCīBAS» analizē spēkā esošos sociālās politikas plānošanas dokumentus Latvijā - pamatnostādnes, lai identificētu tajos ietverto redzējumu par sociālās jomas un pakalpojumu pārvaldību. Savukārt MARTA TRIPĀNE rakstā «VESELİBAS STĀVOKḶA NEVIENLİDZİBA UN VESELİBAS RİCİBPOLITIKA LATVIJĀ» aplūko veselïbas stāvokḷa nevienlïdzību un to ietekmējošos faktorus, kā arī salīdzina iedzivotāju izvirzìtās prioritātes ar prioritātēm veselības politikā.

Monogrāfijas otrajā dalā «Celā uz cienpilnu dzivi» analizēta nabadzība un sociālā atstumtība kā nozīmīgas sociālās problēmas Latvijā, iezīmējot to negatīvo ietekmi uz ilgtspējīgu sociālo un reğionālo attīstību. BAIBA BELA Un JURIJS NIKIŠINS rakstā «ILGTSPĒJAS SOCIĀLĀ DIMENSIJA: VAI VIRZĀMIES PRETİ LABKLĀJIIBAI UN CIENPILNAI DZİVEI?» apskata nabadzỉbas un sociālās atstumtības mērišanas metodiku un, padziḷināti analizējot mājsaimniecību materiālo nenodrošinātību, pievērš uzmanību iedzīvotāju iespējām sasniegt pienācīgu dzives līmeni kā nozimìgam sociālās ilgtspējas faktoram. Autori analizē ienākumu sliekšņus, pie kuriem Latvijas iedzìvotāji sastopas ar resursu deprivāciju un sociālo atstumtību. BAIBA BELA rakstā «NABADZİBAS STRUPCELŠ: GRŪTİBU AKUMULĀCIJA UN RISINĀJUMU MEKLĒJUMI SIEVIEŠU PIEREDZES STĀSTOS» pievēršas vienas seviški ievainojamas 
sociālas grupas pieredzes analīzei-sievietēm, kurām ir zema izglìīiba un kuras audzina bērnus vienas vai kopā ar problemātiskiem partneriem; rakstā pētìts, ko nozīmē dzìve ar ierobežotiem līdzekḷiem uz izaugsmi un patērinu vērstā sabiedrībā. Abos rakstos autori pieskaras pilsētu un lauku iedzīvotāju dzìves lìmeṇa, iespēju un pieejamo pakalpojumu atšḳirībām, kā arī apskata problēmu pārvarēšanas iespējas. Strādājošo nabadzỉbu un sociālās problēmas mājokḷu pieejamībā projekta pētnieki Mareks Niklass un Lỉga Rasnača aplūkos atseviškā izdevumā.

Monogrāfijas trešā daḷa «Sociālās inovācijas labākai dzīvei» aplūko valsts lomu inovāciju sekmēšanā un dziḷāk pievēršas diviem ḷoti atšḳirīgiem sociālo inovāciju piemēriem, kas katrs savā veidā ir saistìti ar cilvēka drošumspēju un dzives kvalitāti. ANETE VINGRE rakstā «SOCIĀLĀS INOVĀCIJAS: VALSTS LOMA TO SEKMĒŠANĀ PASAULĒ UN LATVIJĀ» iepazīstina ar diskusiju par valsts lomu sociālo inovāciju sekmēšanā, analizē starptautisko pieredzi saistībā ar valstu lietotajiem rīcībpolitikas instrumentiem sociālo inovāciju sekmēšanā, kā arī sniedz ieskatu Latvijas situācijā. VINETA SILKĀNE rakstā «PAVIRZİ̌̌ANAS IESPĒJAS VEICINĀT DALİBU VĒŽA SAVLAICİGAS ATKLĀŠANAS PROGRAMMĀ» pievēršas ar veselības uzvedỉbu saistìtam sociālo inovāciju lokam. Autore pēta, kādi pamudinājumi uzaicinātajām personām būtu nozīmīgi, lai tās ierastos uz veselības pārbaudi. Jautājums ir būtisks saistībā ar iedzivotāju drošumspēju veselības jautājumos - no vienas puses, mirstỉbai no onkoloğiskām slimỉbām ir augsti rādītāji (kaut gan mūsdienās onkoloğiskas saslimšanas var sekmīgi ārstēt), bet, no otras puses, iedzīvotāju atsaucība dalībai valsts finansētajā vēža savlaicigasas atklāšanas programmā ir zema. BAIBA HoLMA un GUNA SPURAVA rakstā «BIBLIOTEKĀRA KĀ MEDIATORA LOMA BĒRNU UN JAUNIEŠU DIGITĀLĀS PRATİBAS VEICINĀŠANĀ» pēta informācijpratības, un īpaši digitālās pratības, pilnveidošanas iespējas bērnu un jauniešu vecumgrupā, pievēršoties bibliotekāriem, jo Latvijā bērni un pusaudži lieto internetu bibliotēkās ievērojami vairāk nekā citviet Eiropā. N̦emot vērā arī to, ka no vecāku un pedagogu puses vērojams digitālās pratības mediācijas deficìts, autores skaidro, vai publisko bibliotēku bibliotekāri ir potenciāli gatavi pildìt jaunas sociālās lomas attiecībā uz bērnu un jauniešu digitālās pratîbas pilnveidošanu.

\section{Pateicības}

Monogrāfijas autori izsaka pateicību visiem, kuri snieguši atbalstu pētijuma procesā un grāmatas tapšanas gaitā. Izglìtības un zinātnes ministrijaipar valsts pētijumu programmas finansējumu, kas deva iespēju pētijumu veikt. LU Sociālo zinātnu fakultātes administrācijai - par nozimingo atbalstu visu praktisko un finansiālo jautājumu risināšanā. Tirgus un socioloğisko pètijumu centram «Latvijas Faktì - centrs 2015. gadā veica kvantitatîvu pētījumu «Socioloğiska aptauja par nabadzības un sociālās atstumtības riskiem». Socioloǵijas mağistra studiju programmas studentiem un kultūras un sociālās antropolog̣ijas bakalaura studiju programmas studentiem - vini 2015 un 2016. gadā veica dzivesstāsta intervijas ar cilvēkiem, kuri ir pieredzējuš grūtus dzīves apstākḷus, un 25 intervijas uzticēja arī SUSTINNo pētỉjumam. Pateicamies LU Akadēmiskajam apgādam par patiesām rūpēm grāmatas ceḷā pie lasīāja.

\section{Izmantotie avoti}

Banerjee, B. S. (2003). Who Sustains Whose Development? Sustainable Development and the Reinvention of Nature. Organization Studies, 24(1), pp.143-18o. Retrieved from http://datubazes.lanet.lv:2388/content/24/1/143. full.pdf + html

Brigsa, S., Broka, A., Rajevska, F., Ročāns, K., Romanovska, L., \& Zīverte, L. (2014). Krīze: izaicinājumi un iespējas sociālajai cilvēkdrošibai Latvijā. No J. Rozenvalds, A. Zobena (red.), Daudzveidīgāas un mainīgās Latvijas identitātes (149.-172.lpp.). Rīga: LU Akadēmiskais apgāds.

Buch-Hansen, M., \& Lauridsen, L. S. (2012). The Past, Present and Future of Development Studies. Forum for Development Studies, 39(3), pp. 293-300. doi:10.1080/08039410.2012.709985

Ecological Footprint (n.d.). Earth Overshoot Day. Global Footprint Network: Advancing the Science of Sustainability. Retrieved from http://www. footprintnetwork.org/our-work/ecological-footprint

Kallis, G., Demaria, F., \& D’Alisa, G. (2015). Introduction. Degrowth. In G.D’Alisa, F. Demaria, \& G. Kallis (Eds.), Degrowth:A Vocabulary for a New Era (pp.1-17) New York, London: Routledge. Retrieved from https://www.researchgate. net/publication/271506217_Introduction_of_Degrowth_A_Vocabulary_for_a_ New_Era_2015

Sen, A. (2001). Introduction: development as freedom. Development as freedom. Oxford: Oxford University Press, pp.3-12. Retrieved from https:// books.google.lv/books?id=NQs75PEa618C\&pg=PA3\&hl=lv\&source=gb $\mathrm{s}$ toc $\mathrm{r} \& \mathrm{cad}=3 \# \mathrm{v}=\mathrm{onepage} \& \mathrm{q} \& \mathrm{f}=$ false

Sen, A. (2013). The Ends and Means of Sustainability. Journal of Human Development and Capabilities: A Multi-Disciplinary Journalfor People-Centered Development, 14(1), pp. 6-20. doi:10.1080/19452829.2012.747492

Stiglitz, J.E. (2012). The Price of Inequality. New York, London: W. W. Norton \& Company. doi:dx.doi.org/10.17310/ntj.2015.2.09

United Nations (1995). Gateway to Social Policy and Development. Report of the World Summit for Social Development. A/CONF.166/9, Report adapted 
by UN Department of Economic and Social Affairs on 6-12 March 1995 Retrieved from http://www.un.org/esa/socdev/wssd/text-version/ agreements/poach $2 . h t m$

United Nations (2015). Transforming our world: the 2030 Agenda for Sustainable Development. A/RES/70/1, Resolution adapted by General Assembly on 25 September 2015. Retrieved from https://sustainabledevelopment.un.org/ post2015/transformingourworld

United Nations Development Programme (2010). The Real Wealth of Nations: Pathways to Human Development. Human Development Report. New York: United Nations Development Programme. Retrieved from http://hdr.undp. org/en/reports/global/hdr2010/chapters/

United Nations Development Programme (2011). Sustainability and Equity: A Better Future for All. Human Development Report. New York: United Nations Development Programme. Retrieved from http://hdr.undp.org/en/reports/ global/hdr2011/download/

WCED (1987). Report of the World Commission on Environment and Development: Our Common Future. Oxford, UK: Oxford University Press. Retrieved from http://www.un-documents.net/our-common-future.pdf 


\section{Ilgtspējīgas attīstības} tiesiskie un pārvaldes aspekti 


\section{Ilgtspējīgas attīstības konstitucionālā dimensija}

Šìs nodalas mērkis ir raksturot ilgtspējigas attīstības konstitucionālo dimensiju Latvijā, proti, noskaidrot, vai Satversmē ir ietverts pietiekams ilgtspējigas attīstības jautājumu regulējums un kāda veida rīcibu šajā jomā Satversme paredz. Lai sasniegtu šo mērḳi, autors analizēs ilgtspējigas attīstības principa attīstību Latvijas konstitucionālajā iekārtā, kā arī aplūkos Satversmes normas, kurās ir ietverti atsevišķi ilgtspējigas attīstības principa elementi. Autora izdarītie secinājumi pamatā balstitti uz Satversmes tiesas prakses analīzi, kas papildināta ar Latvijas tiesību zinātnē paustajiem viedokḷiem par analizējamo jautājumu un likumdevēja praksi.

Latvijas Republikas konstitucionālās iekārtas pamatu veido 1922.gada 15. februāra Latvijas Republikas Satversme (turpmāk - Satversme) (Satversmes sapulce, 1922). Satversmes kodifikācijas stilu varētu raksturot kā ekstrēmu lakonismu jeb tekstuālu skopumu, kas principiāli atšḳiras no izvērstajām politiskajām deklarācijām un sīkumainā tehniskā regulējuma, kāds raksturīgs mūsdienu konstitūcijām (Pleps, 2012, 53.-54.lpp.). Satversmes lakonisms nodrošina Satversmes nenovecošanu, jo pieḷauj Satversmes iztulkošanu atbilstoši laikmeta garam un prasībām, orientējoties uz modernas demokrātiskas tiesību sistēmas juridiskajām atzinām (Levits, 2000, 266.lpp.). Šo iemeslu dēḷ Satversmes tiesa ir uzsvērusi, ka «Satversme pēc savas būtỉbas ir ìss, lakonisks, tomēr komplicēts dokuments» (Satversmes tiesa, 2005). Savukārt tas nozimēe, ka Satversme regulē ikvienu aktuālu un sabiedrības dzivei būtisku jautājumu, paredzot noteiktu attiecīgā jautājuma risinājumu. Vajadzīgās atbildes atvasināmas no Satversmes tās iztulkošanas celā, kā arī likumdevējam ir iespēja grozìt vai papildināt Satversmes regulējumu, lai tas precīzāk un skaidrāk sniegtu sabiedrībai nepieciešamās atbildes.

Ilǵtspējiga attīstỉba ir bijis būtisks izaicinājums konstitucionālajām tiesībām aizvadītā gadsimta beigās un šajā gadsimtā. Konstitucionālo tiesību teorijā atzīts, ka konstitucionālo tiesību jēdzienu, normu un principu pabeigtība pat mūsdienu apstākḷos vēl joprojām ir nosacìta. Šajā ziṇā kā piemērs tradicionāli tiek minēti tieši vides aizsardzỉbas un ilgtspējīgas attīstības jautājumi, kas strauji attīstijjušies dažu gadu desmitu laikā (Кудинов, 2006, с.9-10). Ilgtspējīgas attīstības dimensija pašreizējos politiskajos lēmumos un tiesību praksē prasa vērtēt un nemt vērā nākamo paaudžu intereses, kas ir pietiekami liels izaicinājums konstitucionālajās tiesībās (Klepfers, 2003, pp. 325-327).

Latvijas gadỉjumā izškirošos lēmumus par ilgtspējigas attīstības ideju nozīmi konstitucionālajā iekārtā faktiski pienēma Satversmes tiesa, veico metodoloğiski korektu Satversmes iztulkošanu konkrētās lietās. Konceptuāla izškiiršanās par ilgtspējīgas attīstības ideju vietu notika Satversmes tiesa spriedumos, nevis mērktiecīgos Satversmes grozijumos, kurus būtu veicis likumdevējs. Satversmes normas noderēja tikai par pietiekamiem pieturas 
punktiem, lai Satversmes tiesa varētu atzìt, ka ilgtspējigas attīstïbas princips ir viens no Latvijas Republikas konstitucionālās iekārtas vispārējiem tiesību principiem (Satversmes tiesa, 2008a).

Satversmes tiesa gan nav izmantojusi ilgtspèjīgas attīstības principu, un jo īpaši tā elementus, kas saistìti ar sociāli atbildīgas valsts principa nodrošināšanu, lai iezimētu noteiktus valsts pienākumus sociālās nevienlīdzỉbas mazināšanā sabiedrībā. Atsevišķi Satversmes tiesas tiesneši ir aicinājuši katrā lietā, kas saistìta ar valsts atbalsta pasākumiem sociālo un ekonomisko tiesību jomā, definēt, kas ir minimālais apjoms, kurš valstij jānodrošina (Branta, 2006). Tas nozīmētu, ka Satversmes tiesa atbilstoši Satversmei un vispārējiem tiesību principiem noteiktu, cik liels apjoms katrā gadijumā valstij vismaz būtu jāsniedz, lai nodrošinātu atsevišḳu cilvēku vajadzības un îstenotu sociālo taisnīgumu.

Nozīmīgs faktors šajā gadījumā būtu cilvēka cieṇa kā viens no Latvijas konstitucionālās iekārtas pamatiem (Satversmes tiesa, 2017b. Sal.: Kovalevska, 2009). Tajā pašā laikā pozitīvi vērtējama tiesībsarga iniciatīva konsekventi izcelt valsts pienākumu nodrošināt personu sociālās un ekonomiskās tiesības, lai sekmētu sociāli atbildīgas valsts un ilghtspējīgas attīstības principu istenošanu (Matule, 2017). Šĩs jomas iezīmēšana kā viena no tiesībsarga darba prioritātēm un konsekventa uzturēšana dialogā ar Ministru kabinetu, Saeimu un Satversmes tiesu var klūt par svarīgu institucionālu mehānismu sociāli atbildīgas valsts un ilgtspējiggas attīstības principa prasību apzināšanā un ieviešanā.

\section{llgtspējīgas attīstïbas} idejas attīstība

Ilgtspējigas attīstības idejas izplatība pasaulē saistīta ar Apvienoto Nāciju Organizācijas 1992. gada jūnija konferences Riodežaneiro deklarāciju «Par vidi un attīstību» (UN, 1992) un tajā noteiktajiem principiem (Satversmes tiesa, 2008b). Ilgtspējigas attīstỉbas ideja pirmsākumos aptvēra vides aizsardzības un lìdzsvarotas ekonomiskās attīstības jomu (Čepāne \& Meiere, 2011, 718.-721.lpp.; Meiere, 2013, 73.-79.lpp.). Ilgtspējiga attīstība saistās ar rūpēm par nepieciešamību līdzsvarot tagadējās paaudzes rīcības pieḷaujamās robežas ar nākamo paaudžu interesēm. Kā atzinusi Satversmes tiesa, «tiesības uz attīstību ir jāisteno tā, ka tagadējo paaudžu attīstības un vides vajadzības taisnīgā veidā tiek saskaņotas ar nākamo paaudžu vajadzībām» (Satversmes tiesa, 2008b).

Ilgtspējīgas attīstības ideja paredz noteiktus standartus tagadējās paaudzes rīcībai ar pieejamajiem dabas resursiem, lai tās tiesības uz attīstību līdzsvarotu ar nākamo paaudžu interesēm. Pēc būtības tas nozīmē prasību pēc ilgtspējigas, saprātigas, racionālas un taisnigas pieejamo dabas resursu izmantošanas un vides aizsardzības apsvērumu integrācijas citās politikās

un attīstības plānos (Meiere, 2013, 78.lpp.). Tagadējās paaudzes un nākamo paaudžu iespējas dzivvot labvēlīgā vidē ir daudzējādā ziṇā atkarīgas no visu valstu gatavỉbas ìstenot ilgtspējigu attīstību (Satversmes tiesa, 2011a).

Lïdztekus līdzsvarotai ekonomiskajai attīstībai un vides aizsardzỉbai ANo ilgtspējigas attīstỉbas idejā ietvēra arī sociālo attīstỉbu. Sociālās attīstības perspektiva ḷâva atzìt, ka ilgtspējiga attīstība ir ietvars, kas l̦auj ikvienam sasniegt augstāku dzīves kvalitāti (Meiere, 2013, 79.lpp.). Sevišḳi skaidri tas iezīmējās ANO 1995. gada konferences Kopenhāgenā deklarācijā «Par sociālo attīstìbu» (UN, 1995). Laika gaitā ilgtspējiggas attīstības jēdziena saturs ir attisstijies, un tagad šis jēdziens tiek plaši lietots daudzās nozarēs, kurās tam ir sava specifiska nozīme (Satversmes tiesa, 2008b).

Ilgtspējiga attīstỉba Eiropas Savienībā ir definēta kā visaptverošs politikas mērḳis, kas nosaka visu Eiropas Savienības politiku un rīcību. Saskanā ar Lìguma par Eiropas Savienības darbỉbu 11. pantu ilgtspējịgas attīstìbas veicināšana ir viens no Eiropas Savienïbas mērkiem (ES, 2012a). Savukārt Lìguma par Eiropas Savienību preambulā pausta Eiropas Savienības dalībvalstu apnemšanās veicināt savu tautu ekonomisko un sociālo attīstìbu, ievērojot ilgtspējigas attīstības principu, kā arī istenot tādu politiku, kas reizē ar sasniegumiem ekonomikas integrācijā nodrošina attīstỉbu arī citās jomās. Ilgtspējigia attīstība saskaṇā ar Lỉguma par Eiropas Savienību 3. panta trešo dalu noteikta ari par vienu no Eiropas Savienības prioritātēm. Atbilstoši tam Eiropas Savienības darbība ir vērsta uz to, lai panāktu stabilu Eiropas attīstību, kuras pamatā ir lïdzsvarota ekonomiskā izaugsme, sociālā tirgus ekonomika ar augstu konkurētspēju, kā arī sociālā attīstība, vides augsta līmeṇa aizsardzība un tās kvalitātes uzlabošana. Eiropas Savienība paudusi apnēmību apkarot sociālo atstumtību, diskrimināciju un veicināt sociālo taisnīgumu, kā arī paaudžu solidaritāti (ES, 2012b).

Ilgtspējịga attīstība ir sabiedrības labklājỉbas, vides un ekonomikas integrēta un lỉdzsvarota attīstỉba, kas apmierina iedzivotāju pašreizējās sociālās un ekonomiskās vajadzības un nodrošina vides aizsardzības prasību ievērošanu, neapdraudot nākamo paaudžu vajadzību apmierināšanas iespējas, kā arī nodrošina bioloğiskās daudzveidỉbas saglabāšanu (Satversmes tiesa, 2008a). N Nemot vērā ilghtspējigas attīstỉbas regulējumu starptautiskajās tiesībās un Eiropas Savienības tiesībās, arì Latvijas Republikas konstitucionālās iekārtas kontekstā ilgtspējiggas attīstības idejām ir būtiska nozīme (Krūma \& Plepa, 2016, 192.lpp.).

Ilgtspējīga attīstība

Latvijas Republikas konstitucionālajā iekārtā
Ilogtspējiga attīstība konstitucionālo tiesību zinātnē līdz šim izvērsti nav tikus analizēta nedz kā Satversmē noteiktās Latvijas Republikas konstitucionālās 
iekārtas vispārējais tiesību princips, nedz arī kā konstitucionāla vērtība vai Latvijas Republikas politikas mērḳis (Konstitucionālo tiesību komisija, 2012; Pleps, 2013). Arī Satversmes tiesas praksē šis princips vēl līdz galam nav ticis izvērsts. Tomēr Satversmes tiesa ilgtspējigas attīstìbas principu ir atzinusi par Latvijas Republikas konstitucionālās iekārtas vispārējo tiesību principu (Satversmes tiesa, 2008a). Tas nozīmē, ka ilgtspējiggas attīstības princips ir juridiski saistoša tiesibu norma, kas paredz noteiktu rīcības modeli likumdevējam, tiesību piemērotājiem un ikvienam sabiedrības loceklim (Satversmes tiesa, 2009. Sal.: Rezevska, 2015, 146.-147.lpp.). Satversmes tiesa ilgtspējigas attīstỉbas principa elementus atvasinājusi no Satversmes 115. pantā ietvertajām ikvienas personas tiesībām dzīvot labvēlīgā vidē, kā arī konkretizējusi sociāli atbildīgas valsts principa prasības. Savukārt pēc Satversmes tiesas prakses nostiprināšanās pats likumdevējs atsevišḳus ilgtspējiggas attīstības principa elementus Satversmes tekstā ieklāvis ar 2014. gada 19. jūnija grozỉjumu, ar kuru tika izvērsts Satversmes ievads (preambula) (Saeima, 2014).

Būtiski, ka Satversmes tiesa ilgtspējīgas attīstības principa īstenošanu saistijjusi ar cilvēka cieņas kā konstitucionālas vērtības aizsardzỉbu un nodrošināšanu. Satversmes tiesa uzsvērusi, ka konstitucionāli aizsargājama ir tāda vide, kurā persona var pilnvērtīgi, cilvēka cieṇai atbilstoši funkcionēt un attīstìties (Satversmes tiesa, 2017b).

Satversmes tiesa ir norādījusi, ka mūsdienās ilgtspējigas attīstības modelim atbilst tāda attīstỉbas politika, kas sabalansē nepieciešamỉbu veicināt ekonomisko izaugsmi un uzlabot ikviena sabiedrïbas locekḷa dzives kvalitāti, kā arī nepieciešamību nosargāt dabisko vidi nākamajām paaudzēm (Satversmes tiesa, 2009). Pēc Satversmes tiesas ieskata, ilgtspējīgu risinājumu raksturo tā nepieciešamības rūpiggs izvērtējums un sociālais pamatojums (Satversmes tiesa, 2009). Tikai tāds attīstības risinājums, kas ir vispusīgi izvērtēts un pamatots, uzskatāms par ilgtspējīgu (Satversmes tiesa, 2014).

Satversmes tiesa uzsvērusi, ka ilgtspējiggas attīstības centieni ir vērsti uz cilvēkiem un viṇu tiesībām dzìvot veselīgu un produktīvu dzìvi saskaṇā ar dabu. Tādēẹ šajā kontekstā ir jāvērtē ekoloğiskās, ekonomiskās un sociālās ilgtspējas aspekti, kas ir savstarpēji ḷoti cieši saistīti (Satversmes tiesa, 2011a).

TIESİBAS UZ LABVĒLīGu VIDI Ilgtspèjīgas attīstības ideju attīstỉba sākotnēji izpaudās kā valsts pienākums nodrošināt vides un dabas aizsardzību un līdzsvarot ekonomisko attīstỉbu ar vides aizsardzibas interesēm. Tas atspogulojās vides aizsardzības atzīšanā par valsts politikas mērki un konstitucionālu vērtību (Klepfers, 2003, 322.-328.lpp.). Konstitucionālā regulējuma attīstỉba mūsdienās ḷauj runāt par ekoloğiskas valsts vai apkārtējai videi draudzīgas valsts principu kā valsts struktūras principu lỉdzās demokrātiskas, tiesiskas un sociāli atbildīgas valsts principam (Vildbergos, Messeršmits, \& Niedre,
2004, 20. lpp.). Vides aizsardzỉba, pastāvošās ekosistēmas saglabāšana kā konstitucionāla vērtỉba un nepieciešamība novērst apkārtējās vides apdraudējumus, ko rada cilvēka saimnieciskā darbība, bijusi par iemeslu straujai konstitucionālo tiesību attīstībai šajā jomā (Čepāne, 2010, 83.-86.lpp.).

Ar Satversmes grozijumiem 1998. gada 15. oktobrī likumdevējs Satversmē iekḷāva 115. pantu, kas garantēja ikvienas personas tiesības dzivot labvēlìgā vidē (Saeima, 1998). Satversmes 115. pants paredz tiesības dzìvot labvēlīgâa vidē kā t. s. trešās paaudzes jeb kolektivo tiesỉbu, kas ir novatorisks konstitucionāls risinājums. Komentējot Satversmes 115. panta projektu, Egils Levits atzina: «Tiesības uz labvēlīgu vidi vēl nav atzìtas kā piederošas pie cilvēktiesību «kanona», kaut gan par to tiek daudz diskutēts. [..] ja šādas avangardistiskas tiesības Latvijas praksē funkcionētu, tās vēlāk varētu būt paraugs citām valstīm.» (Levits, 1999, 37.lpp.) Vēl jo vairāk - tiesības dzīvot labvēlīgā vidē Satversmes tekstā formulētas nevis kā valsts politikas mērḳi vai pienākumi, bet gan kā subjektivvas personas tiesību garantijas, kuras persona nepieciešamības gadỉjumā var aizstāvēt tiesas ceḷā (Čepāne \& Meiere, 2011, 727.-731.lpp.). Satversmes tiesa secinājusi, ka tiesības dzīvot labvēlīgā vidē, lỉdzịgi kā pārèjās Satversmes 8. nodalạa ietvertās pamattiesības, ir piemērojamas tieši un nepastarpināti (Satversmes tiesa, 2007). Satversmes tiesa praksē plaši izvērsusi Satversmes 115. panta saturu, nodrošinot tā efektīvu piemērošanu Latvijas Republikas konstitucionālajā sistēmā.

Satversmes tiesa uzsvērusi nepieciešamību Satversmes 115. pantā noteiktās tiesības piemērot kopsakarā ar citām Satversmē nostiprinātajām pamattiesībām, tostarp sociālekonomiskajām tiesībām un attiecīgajām starptautiskajām saistībām. Raugoties no ilgtspèjigas attīstības perspektīvas, Satversmes tiesa atzinusi, ka Latvijai ir jāizpilda divi vienlīdz svarīgi un ḷoti sarežǵìiti uzdevumi: jāveicina ekonomiskā izaugsme un līdz ar to-sociālā labklāīiba, bet tajā pašā laikā jānodrošina apkārtējās vides aizsardzỉba un saglabāšana, kā arī personas tiesības dzīvot labvēlīgā vidē (Satversmes tiesa, 2011a). Gan atsevišķu privātpersonu, gan visas sabiedrības ekonomiskās intereses bieži vien prasa pārveidot apkārtējo vidi, tostarp kultūrvidi un dabu. Satversmes tiesa secinājusi, ka Satversmes 115. pants neparedz pastāvošās vides saglabāšanu un neliedz istenot ar ekonomiskajām interesēm saistìtus projektus. Satversmes 115. pants, tieši pretēji, prasa līdzsvarotu un atbildīgu apkārtējās vides uzlabošanu, kas ietver arì cilvēku dzivei piemērotu apstākḷu un sabiedrības labklājỉbas nodrošināšanu (Satversmes tiesa, 2008a). Lìdz ar to Satversmes 115. panta kontekstā pēc iespējas jālīdzsvaro sabiedrības ieinteresētība dzìvot labvēlīgā vidē, no vienas puses, un saimnieciskās attīstības veicināšana, no otras puses (Satversmes tiesa, 2008a).

Satversmes tiesa atzinusi, ka Satversmes 115. pants, pirmkārt, publiskās varas institūcijām uzliek pienākumu izveidot un nodrošināt efektīvu vides aizsardzības sistēmu; otrkārt, privātpersonai pieškiir tiesības 
normatīvajos aktos noteiktā kārtībā iegūt vides informāciju un līdzdarboties ar vides izmantošanu saistītu lēmumu pieṇemšanas procesā; treškārt, tiesībām dzìvot labvēlīgā vidē piešḳir pamattiesību rangu (Satversmes tiesa, 2007). Publiskās varas institūcijām ir pienākums nemt vērā vides aizsardzības intereses, ja notiek politikas mērḳu vai tiesību aktu izstrādāšana un pieṇemšana, kā arì tad, kad pieṇemtie tiesību akti tiek piemēroti un politikas mērḳi tiek istenoti (Satversmes tiesa, 2007).

Satversmes 115. pantā lietotais jēdziens «ikviens» aptver ne vien tagadējās paaudzes, bet arī nākamo paaudžu intereses dzīvot labvēlìgā vidē. Līdz ar to no Satversmes 115. panta izriet prasība visos ar vidi saistitajos jautājumos nemt vērā ne vien tagadējās paaudzes, bet arī nākamo paaudžu tiesības dzìvot labvēlīgā vidē (Satversmes tiesa, 2008b).

SOCIĀLI ATBILDĪGAS VALSTS PRINCIPS Sociāli atbildīgas valsts princips Satversmes tekstā tika ieklauts tikai ar 2014. gada 19.jūnija grozijumu, tiešā tekstā norādot, ka Latvija ir sociāli atbildīga valsts (Saeima, 2014). Tomēr jau ar 1998. gada 15. oktobra grozìjumiem likumdevējs Satversmē iekḷāva vairākas sociālās un ekonomiskās tiesības (Saeima, 1998). Tas bija par pamatu Satversmes tiesas secinājumam, ka Latvijas Republika ir sociāli atbildīga valsts. Satversmes tiesa norādijja: «Latvijas konstitucionālais likumdevējs Satversmē noteicis virkni sociālo tiesību. Tādējādi likumdevējs noteicis, ka Latvija ir sociāli atbildīga valsts, proti, tāda valsts, kas likumdošanā, pārvaldē un tiesas spriešanā cenšas iespējami plaši ìstenot sociālo taisnīgumu. Sociāli atbildīgas valsts mērḳis ir sabiedrībā izlīdzināt būtiskākās sociālās atškirības un katrai iedzivotāju grupai nodrošināt atbilstošu dzives standartu.» (Satversmes tiesa, 2006)

Sociāli atbildīga valsts uzṇemas atbildỉbu par sabiedrïbas eksistenci. Sociāli atbildīga valsts ir mehānisms, ar kura starpniecību tiek nodrošinātas vājāko sabiedrības locekḷu prasības pēc sociālā taisnīguma, pārdalot tiem par labu ekonomiskos labumus (Žilys, 2006, p.17). Sociāli atbildīgas valsts principa nepieciešamība parasti tiek saistita ar cilvēka cienu, taisnīgumu, vienlīdzību un solidaritāti. Cilvēks nedrīkstētu dzīvot tādos ekonomiskos apstākḷos, kas viṇu padarìtu par objektu. Ir jānodrošina vismaz minimāli apstākḷi, lai cilvēks varētu baudìt savas cilvēktiesības (Kovalevska, 2008, 7.lpp.). Valsts sev liek rūpēties par cilvēkiem liktena triecienos un nodrošināt kompensāciju citos dzives negadijumos (Cipeliuss, 1998, 275.lpp.).

No sociāli atbildigas valsts principa izriet valsts pienākums izveidot ilgtspējigu un sabalansētu politiku sabiedrības labklājības nodrošināšanai (Grigore-Bāra u.c., 2014, 214.lpp.). Sociāli atbildīga valsts ir valsts, kurai ir ne tikai tiesības, bet arī pienākumi būt aktivvai un iejaukties ar regulējumu sabiedrības dzīvē, lai nodrošinātu tās iedzìvotāju sociālo aizsardzību un îstenotu sociālo taisnīgumu (Kovalevska, 2013, 256. lpp.). Sociāli atbildìgas valsts princips nozìmē valsts pienākumu nodrošināt cilvēka cienīgu dzives līmeni, kas ietver sociālās palīdzības, pamatpakalpojumu, kā arī izglìtības, veselības un sociālās aprūpes, kultūras iestāžu pieejamības nodrošināšanu, un valsts pienākumu rūpēties par sociālo taisnīgumu, kas ietver rūpes par sociālo atškirību izlīdzināšanu, vājāko aizsardzību un iespēju vienlīdzību (Kovalevska, 2008, 10.-12.lpp.).

Satversmes tiesa uzsvērusi, ka valstij ar savām ekonomiskajām iespējām ir jāsamēro ne tikai personas tiesības sociālajā jomā, bet arī nepieciešamība nodrošināt visas sabiedrības labklājỉbu un jārada tāds tiesiskais regulējums, kas būtu vērsts uz valsts ilgtspējigu attīstību (Satversmes tiesa, 2010). Valstij ir jānodrošina sociālās drošības sistēmas ilgtspēja, garantējot, ka tiesības uz sociālo nodrošinājumu būs îstenojamas arī nākamajās paaudzēs (Satversmes tiesa, 2017a). Tāpat sociāli atbildỉgas valsts princips un ar to saistītās sociālās un ekonomiskās tiesības veido sistēmu, ar kuras palīdzību iespējams mazināt sabiedrībā pastāvošo nevienlīdzību un nodrošināt ikvienas personas (kā arī sabiedrības kopumā) tiesības uz attīstību (Pleps, Pastars, \& Plakane, 2014, 149.-152.lpp.).

SATVERSMES IEVADS Lai apstiprinātu pastāvošo konstitucionālo iekārtu, likumdevējs izšķīrās grozīt Satversmes ievadu (preambulu), lai tajā fiksētu būtiskākos konstitucionālās iekārtas elementus (Anotācija, 2014). Sākotnējā Satversmes ievada teksta piedāvājumā tā autors Egils Levits ietvēra trīs ilgtspējigas attīstỉbas idejas elementus. Pirmkārt, starp Latvijas valsts pamatuzdevumiem tika minēta vides un dabas aizsardzibas nodrošināšana, kā arī ekonomiskās attīstības salāgošana ar cilvēka humānajām vērtībām un vajadzībām. Otrkārt, tika piedāvāts noteikt atbildību par savu rīcību pret vidi, dabu un nākamajām paaudzēm kā ikviena pienākumu. Treškārt, tika paredzēts Latvijas pienākums piedalīties Eiropas un pasaules ilgtspējiggas attīstỉbas sekmēšanā (Levits, 2013a, 8.lpp.).

Komentējot savu Satversmes ievada piedāvājumu, Egils Levits atzina, ka vides un dabas aizsardzība, kā arī ekonomiskās attīstības un cilvēka humāno vērtību un vajadzību salāgošana ir jauns valsts pamatuzdevums, no kura neviena valsts globalizācijas procesu ietekmē nevarēs izvairīties (Levits, 2013b, 15.lpp.). Ilgtspējīgas attīstības kontekstā būtiska ir pašreizējās paaudzes atbildība pret nākamajām paaudzēm. «Atbildība pret nākamajām paaudzēm liedz cilvēkam rīkoties tā, ka viṇa rīcība apdraudētu vai apgrūtinātu nākamo paaudžu dzīvi.» (Levits, 2013b, 17.lpp.) Saeimai izsniegtajā Satversmes ievada grozijumu projektā tika saglabāta norāde uz ikviena pienākumu izturēties atbildīgi pret vidi, dabu un nākamajām paaudzēm, kā arī Latvijas pienākums dot pienesumu pasaules un vienotas Eiropas ilgtspējigai attīstîbai (Anotācija, 2014). Saeima likumdošanas procesā šos Satversmes ievada elementus apstiprināja bez izmainām (Saeima, 2014). 
Satversmes ievads pēc tā spēkā stāšanās ir juridiski saistoša konstitucionāla ranga tiesibu norma (Pleps, 2014, 4., 8.lpp.). Satversmes ievads paredz Latvijas Republikas pienākumu sekmēt ilgtspējīgu attīstību valsts, Eiropas un pasaules līmenī, kā arī atsevišķu personu (lìdz ar to arī pašreizējās paaudzes) konstitucionālos pienākumus šajā jomā (Balodis, 2014, 132.-133.lpp.), ieviešot atbildību nākamo paaudžu priekšā (Ījabs u. c., 2014, 114., 123.lpp.).

Satversmes ievads vēlreiz apstiprina Latvijas Republikai kā Eiropas Savienības dalībvalstij saistošo pienākumu rīkoties atbilstoši kopējiem Eiropas Savienības mērḳiem un principiem ilgtspējigas attīstības jomā. Tas Satversmes 68. pantā ietverts ar 2003. gada 8. maija grozijumiem, kas paredz Latvijas Republikas dalību Eiropas Savienībā (Saeima, 2003). Ar šiem grozijumiem Latvijas Republikas konstitucionālajā iekārtā ir ieviests Eiropas integrācijas princips (Balodis, 2004, 16.-17.lpp.). Šis princips nozīmē Satversmes atvērtību dalībai Eiropas Savienībā; tā ir konstitucionālā norma, kas pielauj Eiropas Savienības tiesību piemērojamību Latvijas tiesiskajā sistēmā. Savukārt tas nozīmē, ka «Eiropas Savienības tiesības ir kḷuvušas par neatnemamu Latvijas tiesību sastāvdaḷı» (Satversmes tiesa, 2008a).

Ilgtspējiga attīstîba ir būtisks Eiropas Savienības politikas mērḳis un Eiropas Savienības tiesiskās sistēmas elements. Lïdz ar to atbilstoši Eiropas integrācijas principam Latvijas Republikai tas ir saistošs kā Eiropas Savienības dalībvalstij (Satversmes 68. panta otrā un trešã dalą). Savukārt Satversmes ievads uzliek Latvijas Republikai aktīvu pienākumu dot savu pienesumu Eiropas Savienības ilgtspējigai attīstỉbai. Tāpat dalība Eiropas Savienībā neliedz Latvijas Republikai savā konstitūcijā noteikt augstākus personas pamattiesïbu aizsardzïbas standartus, tostarp ilgtspējigas attīstības principa piemērošanas jomā (Satversmes tiesa, 2011b).

\section{llgtspējīgas attīstības} perspektivas

Ilgtspējigas attīstības princips uzskatāms par Latvijas Republikas konstitucionālās iekārtas vispārēju tiesību principu, kas ilgtspējigu attīstību padara par Latvijas Republikas politikas mērḳi un paredz noteiktus pienākumus gan Latvijas Republikai, gan arī atsevišķām personām (un pašreizējai sabiedrībai kopumā). Satversmes tiesas prakse liecina, ka Latvijas Republikas konstitucionālajā iekārtā ir nodrošināta ekoloğiskā, ekonomiskā un sociālā ilgtspējiba.

Sociāli atbildīgas valsts princips paredz valsts pienākumu izveidot ilgtspējigu un sabalansētu politiku sabiedrỉbas labklājibas nodrošināšanai, kā arī mazināt sabiedrībā pastāvošo nevienlīdzību un nodrošināt ikvienas personas (kā arī sabiedrības kopumā) tiesības uz attīstību. Satversmes 115. pants specifiski atzīst apkārtējās vides aizsardzību par valsts politikas mērki un konstitucionālu vērtību, kuras nodrošināšanai ikviena persona var pieprasìt tiesības dzìvot labvēlīgā vidē. Savukārt Satversmes ievads paredz ikvienas personas pienākumu izturēties atbildīgi pret vidi, dabu un nākamajām paaudzēm, kā arì Latvijas Republikas pienākumu dot pienesumu pasaules un vienotas Eiropas ilgtspējigai attīstìbai.

No ilgtspējigas attistības principa izrietošās prasības ir saistošas likumdevējam, tiesību piemērotājiem un politikas veidotājiem, kā arī ikvienam sabiedrỉbas loceklim (tostarp sabiedrībai kopumā). Tas nosaka pieḷaujamās rīcības robežas tagadējai paaudzei, paturot prātā arī nākamās paaudzes intereses. Šo principu iedzivināšana un îstenošana ir atkarīga no politikas veidotājiem un likumdevēja, kā arī no pašām personām, proti, vai personas, kuras uzskata, ka atsevišǩs gadījumos netiek ievērotas ilgtspējigas attīstïbas principa prasības, būtu gatavas vērsties tā aizsardzībai tiesā.

Latvijas Republikas konstitucionālajā iekārtā ir pietiekami efektīi priekšnoteikumi ilgtspējīgas attīstības principa prasību aizsardzỉbai tiesā. Satversme paredz personas tiesības dzivot labvēlīgā vidē un personas sociālās un ekonomiskās tiesības kā tiesas ceḷā aizsargājamas personas pamattiesības, nevis tikai kā valsts politikas mērḳi vai konstitucionālu vērtību. Tas nodrošina iespēju Satversmes tiesai, izskatot konkrētu personu konstitucionālās sūdzības, veidot un attīstīt ilgtspējigigas attīstības principa saturu, kā arī padarìt tā prasības saistošas likumdevējam un politikas veidotājiem konkrētu lēmumu piennemšanā. Šajā jomā būtu sagaidāma Satversmes tiesas aktīva pozicija attiecībā uz valsts pienākumu apjoma definēšanu, proti, kāds ir minimālais apjoms atsevišķu sociālo un ekonomisko tiesību nodrošināšanā.

\section{Izmantotie avoti}

Anotācija (2014). Latvijas Republikas 11. Saeimas likumprojektam Nr. 1075/Lp11 «Grozijums Latvijas Republikas Satversmē». Izgūts no http://titania.saeima. lv/LIVS11/saeimalivs11.nsf/o/64D394CCE1123A42C2257C7Doo523485?OpenD ocument

Balodis, R. (2004). The Constitution of Latvia. Trier: Institut für Rechtspolitik an der Universität Trier.

Balodis, R. (2014). Latvijas Republikas Satversmes ievads. No Latvijas Republikas Satversmes komentāri. Ievads. I nodala. Vispārējie noteikumi. Autoru kolektivvs prof. R. Baloža zinātniskā vadỉbā. Rīga: Latvijas Vēstnesis.

Branta, A. (2006). Atsevišķās domas lietā Nr. 2006-10-03 «Par Ministru kabineta 2004.gada 7. decembra noteikumu Nr. 1003 «Kārtỉba, kādā piešḳir un izmaksā bērna kopšanas pabalstu un piemaksu pie bērna kopšanas pabalsta par dvinniem vai vairākiem vienās dzemdībās dzimušiem bērniem» 3.1. punktā un Ministru kabineta 2006. gada 8. augusta noteikumu Nr.644 «Noteikumi par bērna kopšanas pabalsta un piemaksas pie bērna kopšanas pabalsta 
par dvīniem vai vairākiem vienās dzemdībās dzimušiem bērniem apmēru, tā pārskatišanas kārtỉbu un pabalsta un piemaksas piešķiršanas un izmaksas kārtỉbu» 2.2. punktā ietvertās normas vārdu «un ne vairāk kā 392 lati mēnesī» atbilstïbu Latvijas Republikas Satversmes 91. pantam». Izgūts no

http://www.satv.tiesa.gov.lv/wp-content/uploads/2016/o2/2006-10-03 Atseviskas_domas.pdf

Cipeliuss, R. (1998). Vispārējē mācība par valsti. Rïga: AGB.

Čepāne, I. (2010). Sabiedribas tiesību aizsardzības efektivitāte teritorijas plānošanas lietās. No Aktuālās cilvēktiesību aizsardzības problēmas. Konstitucionālā südzïba. Satversmes tiesas 2008. un 2009. gada konferenču materiālu krājums. Rỉga: Tiesu namu ag̉entūra.

Čepāne, I., \& Meiere, S. (2011). Satversmes 115. pants. No Latvijas Republikas Satversmes komentāri. VIII nodala. Cilvēka pamattiesības. Autoru kolektīvs prof. R. Baloža zinātniskā vadībā. Rigga: Latvijas Vēstnesis.

Grigore-Bāra, E., Kovalevevska, A., Liepa, L., Levits, E., Mits, M., Rezevska, D., ... Sniedzite, G. (2014). Satversmes 1. pants. No Latvijas Republikas Satversmes komentāri. Ievads. I nodaḷa. Vispārējie noteikumi. Autoru kolektivss prof R. Baloža zinātniskā vadībā. Rīga: Latvijas Vēstnesis.

ES (2012a). Lìguma par Eiropas Savienības darbỉbu konsolidētā versija. Eiropas Savienības Oficiālais Vēstnesis, 55. sējums, 26.10.2012. Izgūts no https://www. ecb.europa.eu/ecb/legal/pdf/c_32620121026lv.pdf

ES (2012b). Lìguma par Eiropas Savienību konsolidētā versija. Eiropas Savienības Oficiālais Vēstnesis, 55. sējums, 26.10.2012. Izgūts no https://www.ecb.europa. eu/ecb/legal/pdf/c_32620121026lv.pdf

İjabs, I., Levits, E., Paparinskis, M., \& Pleps, J. (2014). Satversmes 2. pants. No Latvijas Republikas Satversmes komentāri. Ievads. I nodaḷa. Vispārējie noteikumi. Autoru kolektivss prof. R. Baloža zinātniskā vadībā (253.lpp.). Rīga: Latvijas Vēstnesis.

Klepfers, M. (2003). Vides aizsardziba konstitucionālajās tiesỉbās: Vācijas Pamatlikuma 2o.a pants. Likums un Tiesibas, 11.

Konstitucionālo tiesibu komisija (2012). Viedoklis «Par Latvijas valsts

konstitucionālajiem pamatiem un neaizskaramo Satversmes kodolu».

No Par Latvijas valsts konstitucionālajiem pamatiem un neaizskaramo Satversmes kodolu. Konstitucionālo tiesïbu komisijas viedoklis un materiāli. Rīga: Latvijas Vēstnesis.

Kovaḷevska, A. (2008, 26. aug.). Sociāli atbildīgas valsts princips. Jurista Vārds, 32. Kovalevska, A. (2009, 22. dec.). Tiesibas uz atbilstošu dzives limeni. Jurista Vārds, 51/52.

Kovalevska, A. (2013). Latvijas Republika kā sociāli atbildīga valsts. No Tiesību interpretācija un tiesību jaunrade $-k \bar{a}$ rast pareizo lìdzsvaru. Latvijas Universitātes 71. zinātniskās konferences rakstu krājums. Rīga: Latvijas Universitāte.
Krūma, K., \& Plepa, D. (2012). Constitutional Law in Latvia. The Netherlands: Kluwer Law International BV.

Levits, E. (1999). Piezīmes par Satversmes 8. nodaḷ - Cilvēka pamattiesỉbas. Cilvēktiesību Žurnāls, 9-12.

Levits, E. (2000). Samērīguma princips publiskajās tiesībās - jus commune europaeum un Satversmē ietvertais konstitucionāla ranga princips. Likums un Tiesības, 9.

Levits, E. (2013a, 24. sept.). Izvērstas Satversmes preambulas iespējamā teksta piedāvājums. Jurista Vārds, 39.

Levits, E. (2013b, 24. sept.). Izvērstas Satversmes preambulas teksta piedāvājuma komentārs. Jurista Vārds, 39 .

Matule, S. (2017). Vai tiesïbsarga darbam ir jēga un rezultāts. Intervija ar Juri Jansonu un Inetu Piḷāni. Jurista Värds, 6.

Meiere, S. (2013). Tiesïbas uz labvēlīgu vidi un to istenošanas tiesiskās problēmas Latvijā (promocijas darbs). Rịa: Latvijas Universitāte.

Pleps, J. (2012). Par Latvijas Republikas Satversmi: vēsture un mūsdienas. No R. Apsitis, J.Pleps (zin.red.), Latvijas Republikas Satversme. Rïga: Latvijas Vēstnesis.

Pleps, J. (2013). Latvijas valsts konstitucionālie pamati. No T.Jundzis, G. Zemîtis (zin. red.), Latvieši un Latvija. Akadēmiski raksti. III sëjums. Atjaunotä Latvijas valsts. Riga: Latvijas Zinātnu akadēmija.

Pleps, J. (2014, 5. aug.). Satversmes ievada piemērošana. Jurista Vārds, 30

Pleps, J., Pastars, E., \& Plakane, I. (2014). Konstitucionālās tiesības (papildināts un pārstrādāts izdevums). Rigaa: Latvijas Vēstnesis.

Rezevska, D. (2015). Vispārējo tiesību principu nozīme un piemērošana. Rīga: Daigas Rezevskas izdevums.

Saeima (1998, 23. okt.). Grozijumi Latvijas Republikas Satversmē. Latvijas Vēstnesis, $308 / 312$.

Saeima (2003, 22. maijs). Grozijumi Latvijas Republikas Satversmē. Latvijas Vēstnesis, 76 .

Saeima (2014, 8. jūl.). Grozijjums Latvijas Republikas Satversmē. Latvijas Vēstnesis, 131 .

Satversmes sapulce (1922, 30. jūn.). Latvijas Republikas Satversme. Ar grozijumiem, kas izsludināti lïdz 31.05.2016. Valdības Vêstnesis, 141. Konsolidēts Satversmes teksts izgūts no https://likumi.lv/doc.php?id=57980

Satversmes tiesa (2005, 20. dec.). Par Ministru kabineta 2005. gada 11. janvāra noteikumu Nr. 17 «Grozijumi likumā «Par nekustamā īpašuma piespiedu atsavināšanu valsts vai sabiedriskajām vajadzïbām»» un 2005.gada 9.jūnija likuma «Grozijjumi likumā «Par nekustamā īpašuma piespiedu atsavināšanu valsts vai sabiedriskajām vajadzībām»» atbilstibu Latvijas Republikas Satversmes 1. un 105. pantam: 16.12.2005. spriedums lietā Nr. 2005-12-0103. Latvijas Vēstnesis, 203. 
Satversmes tiesa (2006, 7.nov.). Par likuma «Grozijumi Valsts sociālo pabalstu likumā» 1. panta dạas, ar kuru Valsts sociālo pabalstu likumā ieviests jauns 7. panta pirmās dą̣as 3. punkts, un 2. panta atbilstibu Latvijas Republikas Satversmes 110. pantam: Satversmes tiesas 02.11.2006. spriedums lietā Nr. 2006-07-01. Latvijas Vēstnesis, 177.

Satversmes tiesa (2007, 28. dec.). Par Ādažu novada teritorijas plānojuma dalıas, kas paredz Lielā Baltezera applūstošās teritorijas apbūvi, atbilstiibu Latvijas Republikas Satversmes 115. pantam: 21.12.2007. spriedums lietā Nr. 2007-1203. Latvijas Vēstnesis, 207.

Satversmes tiesa (2008a, 23. janv.). Par Rīgas teritorijas plānojuma dạlas 2006.2018. gadam, kas attiecas uz Rīgas brìvostas teritoriju, atbilstỉbu Latvijas Republikas Satversmes 115. pantam: 17.01.2008. spriedums lietā Nr. 2007-1103. Latvijas Vēstnesis, 12.

Satversmes tiesa (2008b, 30. sept.). Par Rīgas domes 2006. gada 19. decembra saistošo noteikumu Nr.67 «Teritorijas Maskavas ielā 264 (kadastra Nr. 01000780413) un Maskavas ielā bez numura (kadastra Nr. 01000781004), izmantošanas un apbūves noteikumi» atbilstību Teritorijas plānošanas likuma 3.panta 1.punktam, Aizsargjoslu likuma 37. panta pirmās dą̣as 4. punktam un Latvijas Republikas Satversmes 115. pantam: 24.09.2008. spriedums lietā Nr. 2008-03-03. Latvijas Vēstnesis, 151.

Satversmes tiesa (2009, 8. jūl.). Par Jūrmalas pilsētas domes 2004.gada 28. aprïla saistošo noteikumu Nr. 8 «Grozỉjumi Jūrmalas pilsētas Attīstibas plānā (G̣enerālplānā)» un Jūrmalas pilsētas domes 2007.gada 12. jūlija saistošo noteikumu Nr. 19 «Par Jūrmalas Attīstības plāna (gீenerālplāna) grozijumu, grafiskās daḷas, teritorijas izmantošanas un apbūves noteikumu apstiprināšanu», ciktāl šie noteikumi attiecas uz teritoriju Dzintaros starp Meža prospektu, Edinburgas prospektu, Piestātnes ielu un Krišjānna Barona ielu, atbilstību Latvijas Republikas Satversmes 1. un 115. pantam un Jūrmalas pilsētas domes 2007.gada 30. augusta saistošo noteikumu Nr. 37 «Par detālplānojuma teritorijai Dzintaros starp Meža prospektu, Edinburgas prospektu, Indras ielu un Krišjāṇa Barona ielu projekta grafiskās dạas, teritorijas izmantošanas un apbūves noteikumu apstiprināšanu» atbilstibu Latvijas Republikas Satversmes 115. pantam: 06.07.2009. spriedums lietā Nr. 2008-38-03. Latvijas Vēstnesis, 106. Satversmes tiesa (2010, 17. marts). Par likuma «Par valsts pensiju un valsts pabalstu izmaksu laika periodā no 2009. gada lïdz 2012.gadam» 5. panta pirmās dalas atbilstïbu Latvijas Republikas Satversmes 1., 91. un 110. pantam: Satversmes tiesas 15.03.2010. spriedums lietā Nr. 2009-44-01. Latvijas Vēstnesis, 43.

Satversmes tiesa (2011a, 1. marts). Par Rucavas novada domes 2009. gada 3. novembra saistošo noteikumu Nr. 27 «Par Rucavas novada teritorijas plānojumiem» dạ̦ā par vēja enerğijas zonas noteikšanu Dunikas pagasta teritorijā atbilstibu Latvijas Republikas Satversmes 105. un 115. pantam: 24.02.2011. spriedums lietā Nr. 2010-48-03. Latvijas Vēstnesis, 33.
Satversmes tiesa (2011b, 21. okt.). Par Krediitiestāžu likuma 59.5 panta atbilstỉbu Latvijas Republikas Satversmes 1. un 105. pantam: 19.10.2011. spriedums lietā Nr. 2010-71-01. Latvijas Vēstnesis, 167.

Satversmes tiesa (2014, 10. okt.). Par Pāvilostas novada domes 2013. gada 3o. maija saistošo noteikumu Nr. 3 «Par Pāvilostas novada teritorijas plānojumu 2012.-2024. gadam Teritorijas izmantošanas un apbūves noteikumi un Grafiskā daḷa», ciktāl tie attiecas uz dabas liegumam «Pāvilostas pelēkā kāpa» piegulošo Zaḷalna mežu un dabas liegumam «Ziemupe» piegulošo Akmeṇraga meža dalıu, atbilstibu Latvijas Republikas Satversmes 115. pantam: 09.10.2014. spriedums lietā Nr. 2013-19-03. Latvijas Vēstnesis, 201.

Satversmes tiesa (2017a, 19.jūn.). Par likuma «Par valsts pensijām» 11. panta ceturtās dạ̦as atbilstibu Latvijas Republikas Satversmes 91.panta pirmajam teikumam un 109. pantam: 15.06.2017. spriedums lietā Nr. 2016-11-01. Latvijas Vēstnesis, 121.

Satversmes tiesa (2017b, 21. dec.). Par Ministru kabineta 2014. gada 7.janvāra noteikumu Nr. 16 «Trokšṇa novērtēšanas un pārvaldības kārtïba» 2. pielikuma 2. punkta atbilstibu likuma «Par piesārṇojumu» 2. panta 7. punktam, 18.1 panta trešajai dalai un Latvijas Republikas Satversmes 111. un 115. pantam, kā arī šo noteikumu 2.4.apakšpunkta, ciktāl tas attiecas uz publiskiem pasākumiem autosportā un motosportā, kas norisinās apdzīvotā vietā (pilsētā vai ciemā) izvietotā atklātā autosporta un motosporta bāzēe un kuriem Publisku izklaides un svētku pasākumu drošỉbas likumā noteiktajā kārtībā ir izsniegta aț̣auja publisku pasākumu rikošanai, atbilstỉbu likuma «Par piesārṇojumu» 2. panta 7. punktam un Latvijas Republikas Satversmes 111. un 115. pantam: 19.12.2017. spriedums lietā Nr. 2017-02-03. Latvijas Vēstnesis, 254.

UN (1992). Rio Declaration on Environment and Development. Retrieved from http:// www.unesco.org/education/pdf/RIO_E.PDF

UN (1995). Declaration and Programme for Action of the World Summit for Socia Development. Retrieved from http://www.unesco.org/education/pdf/ COPENHAG.PDF

Vildbergos, H.J., Messeršmits, K., \& Niedre, L. (2004). Pilsonis tiesiskā valstī. Vācu konstitucionālo un administratīvo tiesību pamati. Rīga: Latvijas Universitāte. Žilys, J. (2006). Socialinè valstybė konstitucinèje teisèje. Jurisprudencija, t.12. Кудинов, О.А. (2006). Конституционные проекты Белого движения и конституционно-правовье теории российской белоэмиграции (19181940-е г2.) или За что их расстреливали и депортировали (для тех, кто хочет понять смыссл права). Москва: Ось. 


\section{Sociāli atbildìgas valsts princips \\ kā Latvijas Republikas valsts iekārtu raksturojošs princips}

1 Šo principu Latvijā apzimē arī ar terminiem «socivalsts» (Kovalevska, 2008).

2 Šajā rakstā ir tālāk attistiti autores veiktie pētijum principu, huil as valsts loti iepriekšèjās publikācijās: Kovalevska, A. (2008, 26. aug.). Sociāli atbildigas valsts princips. Jurista Värds, 32(537): GrigoreBāra, E., Kovalevska, A. Liepa, L., Levits, E. Mits, M., Rezevska, D., ... Sniedzite,, . (2014). 1. pants. No Latvijas Republikas Satversmes komentäri. Ievads. 1. nodala. Vispārējie noteikumi. Auto kolektîvs R. Baloža zinātniskā vadibā (210.-223.lpp.). Rìga: Latvijas Vēstnesis.
Ar jēdzienu «valsts iekārta» apzīmē valsts varas institucionālo uzbūvi, valsts varas politisko leğitimāciju, valsts varas lēmumu pieñemšanas procesu un valsts varas darbības saturiskos pamatprincipus. Gan teorijā ir attīstìtas, gan arī praksē pastāv dažādas valsts iekārtas. Valsts iekārtas var klasificēt pēc vairākām pazìmēm. Piemēram, klasificējot valsts iekārtas pēc līdzdalības valsts pārvaldīšanā, tiek nodalïtas monokrātijas, oligarhijas un demokrātijas. Valstis var iedalīt arī monarhijās un republikās atkarībā no tā, vai valsts galva savu amatu iegūst mantošanas ceḷā. Atkarībā no leğitimācijas avota valstis var iedalīt demokrātijās, autoritāros un totalitāros režīmos (Grigore-Bāra u.c., 2014, 161.lpp.).

Mūsdienās Rietumu pasaules modernā valsts iekārta ir konstitucionāla demokrātija, kas nozimēè, ka valsts vara, no vienas puses, ir piesaistìta tiesībām, bet, no otras puses, tā ir piesaistīta tautas gribai. Arī konstitucionālu demokrātiju kā valsts iekārtu var iedalīt vairākos tipos - piemēram, tieša va reprezentatīva demokrātija, prezidentāla, semiprezidentāla vai parlamentāra demokrātija. Lìdz ar to katra konstitucionāli demokrātiska valsts veido savu konkrēto konstitucionālās demokrātijas modeli (Grigore-Bāra u. c., 2014, 172-172.lpp.).

Ja valsts iekārtu raksturo atkarībā no valsts varas darbības saturiskajiem pamatprincipiem, tad modernu attīstītu Rietumu tipa konstitucionāl demokrātisku valsti mūsdienās raksturo demokrātijas virsprincips un tiesiskas valsts virsprincips, jo šie principi ir konstitucionālās demokrātijas iekārtas pamats. Vismaz Eiropā konstitucionālas demokrātijas valsts iekārtu parasti raksturo arī sociāli atbildīgas valsts ${ }^{1}$ virsprincips (Katrougalos, 20122013, pp.105-106; Konstitucionālo tiesību komisija, 2012, 232. punkts; Levits, 2013, 91. lpp.). Tā kā Latvija juridiski normatīi orientējas uz modernas, attīstìtas Rietumu tipa Eiropas demokrātiskas valsts modeli, tad Latvijas demokrātisko valsts iekārtu raksturo šādi četri valsts varas darbibas saturiskie pamatprincipi: 1) demokrātijas virsprincips, 2) tiesiskas valsts virsprincips, 3) sociāli atbildīgas valsts virsprincips, 4) nacionālas valsts virsprincips (Grigore-Bāra u.c., 2014, 178.lpp.; Konstitucionālo tiesibu komisija, 2012, 375. punkts).

Nodalas mērkis ir analizēt sociāli atbildīgas valsts virsprincipu kā Latvijas Republikas valsts iekārtu raksturojošu principu. Lìdz ar to šajā nodạāā apskatīta sociāli atbildīgas valsts idejas vēsturiskā attīstība gan pasaulē, gan arī Latvijā, definēts šì principa saturs Latvijā, kāa arī sīkāk skaidrots, kādi pienākumi un tiesības Latvijas Republikai izriet no ši principa. ${ }^{2}$ 


\section{Sociāli atbildīgas valsts} idejas vēsturiskā attīstība

SOCIĀLI ATBILDīcas VALSTS IDEjas VĒsTURISKĀ ATTİsTīBa PASAULĒ Sociāli atbildīgas valsts princips nozimē to, ka atškirības un aizsargājot sociāli vājākos (Maunz \& Dürig, 2014, S. 7; Muckel, 2009, S. 27). Sociāli atbildīgai valstij ir jāveicina tādi apstākḷi, kas sekmē indivìdu un sabiedrības grupu patiesu un efektīvu vienlïdzỉbu, kā arī nodrošina to, ka indivīds ne tikai teorētiski, bet arī praktiski var istenot savas brīibas (Roca, 2012-2013, p. 217; Maunz \& Dürig, 2014, S. 8). Tādējādi tiek atzìts, ka valstij mūsdienās ir aktīva loma, nevis tikai «naktssarga loma».

Sociāli atbildīgas valsts princips balstās uz tādiem konceptiem kā cilvēka cienna, taisnīgums un vienlīdzỉba, kā arī solidaritāte. Cilvēka cienas garantēšana prasa rūpēties, lai tiktu nodrošināti cilvēka cienīgas eksistences minimālie priekšnoteikumi un lai cilvēkam nebūtu jādzīvo tādos ekonomiskos apstāklos, kas vinu padarītu par objektu. No taisniguma izriet prasība, lai cilvēkiem ne tikai formāli tiktu nodrošināta vienlīdzība, bet arī lai faktiski tiem būtu vienlīdzịgas iespējas realizēt savas tiesības. Savukārt solidaritāte nozīmè, ka cilvēkiem ir pienākums cits citam palīdzēt. İpaši nozimiğga solidaritāte ir industrializētās sabiedrībās, kur pastāv darba dalī̌ana, jo šādos apstākḷos cilvēki ir īpaši atkarīgi cits no cita (Saaremäel-Stoilov, 2007, pp. 83-93; Maunz \& Dürig, 2014, S.13; Muckel, 2009, S. 28; Campanelli, n.d., paras 1-10).

Sociāli atbildīgas valsts idejas pirmsākumi tiek saistīti ar 19. gadsimta sociālajām, ekonomiskajām un politiskajām pārmaiṇām. Industrializācija radijja nepieciešamỉbu aizsargāt darbiniekus pret ekspluatāciju. Turklāt tradicionālās labklājības nodrošināšanas formas izzuda, attīstoties kapitālismam, industrializācijai, urbanizācijai un pieaugot iedzivotāju skaitam, kā arī sabiedrības sekularizācijas rezultātā, un tas radỉja lielu nabadzību. Taču vienlaikus industrializācija palielināja produktivitāti, kas lāva atvēlēt noteiktus resursus sociālo problēmu risināšanai (Mathieu, 2012-2013, p.177; Castles et al., 2010, pp. 3-4). Lìdz ar to arī attīstijjās ideja, ka valstij ir pienākums rūpēties par tās iedzìvotājiem, regulējot sociālo un ekonomikas jomu.

Par šĩs idejas pamatlicēju uzskata vācu ekonomistu un juristu Lorencu fon Šteinu (Lorenz von Stein) (Hеinig, 2008, S. 56; Калашников, 2002, с. 61), kurš jau 19. gadsimta vidū veica pamatīgu un vispusīgu analīzi par to, kāpēc nepieciešama valsts iejaukšanās sociālajos apstākḷos, lai regulētu škiru pretrunas (Kaufmann, 2012, p. 89). Jau šajā laikā, runājot par valsti, viṇš lietoja terminu «sociāla demokrātija», bet vēlāk - arī terminu «sociāla valsts» (Ritter, 1991, S. 11). Lorencs fon Šteins secināja, ka liberāla kapitālisma apstākḷlos dažādu sabiedrības šķiru konflikts ir neizbēgams un var novest pie pilsoṇu kara. Kā risinājumu viṇš piedāvāja sociālās reformas, kas balstītas uz valsts atbildỉbu. L. fon Šteins uzskatijja, ka sociālas valsts uzdevums ir gan aizsargāt privātīpašuma pastāvēšanai nepieciešamos apstākḷus, tādējādi veicinot patstāvīgas komercdarbības kapacitātes attīstību, gan arī uzlabot strādājošo darba un dzìves apstākḷus (Kaufmann, 2012, pp.66-67). Valstij, izmantojot savu varu, jāveicina visu savu pilsonu ekonomiskā un sociālā attīstība, jo viena pilsona attīstiba ir priekšnoteikums otra pilsona attistibai (Ritter, 1991, S. 11; Калашников, 2002, с. 61). Vienlaikus viņš uzskatija, ka arì sociāla valsts tomēr nedrīkst būt pārāk aktīva un valstij sava loma pašai ir jāierobežo. Proti, viṇš norādija, ka valsts nedrīkst nekādos apstākḷos piedāvāt neko vairāk kā tikai radīt personiskai, ekonomiskai un sociālai attīstībai nepieciešamos pstāklus, kurus indivìds nevar pats sev nodrošināt, un tad tai jālauj pašam indivīdam realizēt savu brīvo gribu savas dzives veidošanai un attīstî̌sanai, izmantojot šos apstākḷus (Kaufmann, 2012, pp. 67-68).

Sociāli atbildīgas valsts ideja 19. gadsimtā ne tikai tika attīstīta teorētiski, bet arī tika uzsākta tās praktiska realizācija. Viena no šādām jomām bija bērnu darba ierobežošana. Piemēram, Lielbritānijā mēǵinājumi regulēt bērnu darbu sākās jau 19. gadsimta sākumā. Taču pirmais bērnu darbu ierobežojošais likums, kurā bija paredzēts arī tā îstenošanas uzraudzības mehānisms, tika pieṇemts 1833. gadā. Šajā likumā tika aizliegts nodarbināt bērnus, jaunākus par 9 gadiem. Bērniem vecumā no 9 līdz 13 gadiem darba laiks nedrīkstēja pārsniegt 8 stundas, bet bērniem vecumā no 13 lĩdz 18 gadiem - 12 stundas. Turklāt strādājošiem bērniem vecumā līdz 13 gadiem bija jānodrošina pamata izglitības sniegšana vismaz 2 stundas dienā (UK Parliament Website, n. d.). Vācijā lïdzīgs likums, kas tiek uzskatìts par pirmo normatīvo tiesību aktu, kurā ir îstenota sociāli atbildīgas valsts ideja, tika pienemts 1839.gadāa (Maunz \& Dürig, 2014, S. 8). 19. gadsimta otrajā pusē valstis sāka pieṇemt likumus par sociālo apdrošināšanu, un šis process lavinveidigi turpinājās ar 20. gadsimta sākumā (Калашников, 2002, с. 63-66). Par pirmo valsti, kas pienēma šādus likumus, tiek uzskatìta Vācija, kur 19.gadsimta 80.gados Oto fon Bismarks (Otto von Bismarck) ieviesa sociālo apdrošināšanu slimības, darba negadijjumu, invaliditātes un vecuma gadījumā (Castles et al., 2010, p. 35; Mucenieks, 1934, 14.lpp.). Savukārt Lielbritānijā, lai arī zināmi valsts mēğinājum rūpēties par iedzīvotāju sociālo nodrošinājumu pastāvēja jau agrāk, sociāl atbildīgas valsts ideja tiek saistìta ar lorda Viljama Beveridža (William Beveridge) 1942. gada zinojumu par sociālo drošỉbu (Ideju vārdnīca, b. g., 295. lpp.).

Lai arī valstis jau 19. gadsimtā sāka realizēt politiku, kuras pamatā ir sociāli atbildīgas valsts ideja, tomēr tikai 1949. gadā Vācija kḷuva par pirmo valsti, kuras konstitūcijā tika skaidri noteikts, ka tā ir sociāli atbildīga valsts (Калашников, 2002, c. 70). ${ }^{3}$ Vācijas Federatīvās Republikas konstitūcijā (Parliamentary Council, 1949) norādīts, ka Vācija ir sociāla federāla valsts, un ir minēts arì sociālas tiesiskas valsts princips (20. un 28. pants). Pirms tam Vācijas konstitūcijās bija ieklauti tikai atseviški noteikumi, kurus varēja saistīt 
ar sociāli atbildīgas valsts ideju. Tā Vācijas 1849. gada konstitūcijā vienīgās normas, kuras kaut kādā mērā varēja saistīt ar sociāli atbildīgas valsts ideju, bija normas par valsts pienākumu nodrošināt bezmaksas izglitību. Vācijas 1871. gada konstitūcijas ievadā tika norādīts, ka valsts uzdevums ir Vācijas tautas labklājības veicināšana. Savukārt 1919. gada konstitūcijā sociāli atbildīgas valsts ideja bija atspoguḷota jau daudz plašāk, paredzot atbalstu ǵimenēm, sociālu aizsardzību daudzbērnu ğimenēm un mātēm, bērniem aizsardzību no ekspluatācijas, plašas vienlīdzības garantijas, valsts nodrošinātu bezmaksas izglìtību, noteikumu par īpašuma kalpošanu arī sabiedrības interesēm, darba aizsardzības un darba tiesību regulēšanu ar likumiem, arodbiedrību brīvību, sociālo apdrošināšanu. Turklāt šis konstitūcijas 151. pants noteica, ka valsts ekonomiskajai sistēmai ir jābūt balstìtai uz taisnīgumu, lai visiem nodrošinātu cilvēka cienīgu eksistenci (Zacher, 2008, S.10-11).

Mūsdienās sociāli atbildīgas valsts princips konstitūcijās var būt nostiprināts divos veidos. Pirmkārt, ir valstis, kuru konstitūcijās, lietojot dažādus formulējumus, tieši noteikts, ka tās ir sociāli atbildīgas valstis. Piemēram, Francija tās konstitūcijā (The Constitution of France, 1958) ir raksturota kā sociāla republika (1. pants), bet Krievija (The Constitution of the Russian Federation, 1993) un Spānija (The Constitution of Spain, 1978) - kā sociālas valstis (attiecigi 7. un 1.pants). Polijas konstitūcijā (The Constitution of the Republic of Poland, 1997) ir noteikts, ka Polijas Republika ir demokrātiska tiesiska valsts, kas realizē sociālā taisnīguma principu (2. pants). Otrkārt, ir valstis, kuru konstitūcijās nav tieši noteikts, ka tās ir sociāli atbildỉgas valstis, tomēr šāds secinājums izriet no cita konstitūcijā ietvertā regulējuma. Pie šādām valstīm pieder, piemēram, Igaunija, Lietuva un Itālija. Igaunijas konstitūcijā nav noteikts, ka Igaunija ir sociāli atbildīga valsts, taču tās ievadā ir norādìts, ka valsts sola gan tagadējām, gan nākamajām paaudzēm sociālu progresu un labklājību. Konstitūcijā ir ietverts arī plašs sociālo un ekonomisko tiesību klāsts, savukārt tās 10. pantā ir minēts uz sociālo taisnigumu balstìtas valsts princips (The Constitution of the Republic of Estonia, 1992). Igaunijas Republikas Augstākā tiesa ir atzinusi, ka tas ir konstitucionāls princips, kurš valstij jāievēro (Constitutional Review Chamber of the Supreme Court, 2004, paras 14 and 16). Savukārt Lietuvas konstitūcijā (The Constitution of the Republic of Lithuania, 1992) sociāli atbildīgas valsts princips vispār nav minēts. Tomēr Lietuvas Republikas Konstitucionālā tiesa ir norādījusi, ka atbilstoši konstitūcijai Lietuva ir sociāli orientēta valsts, un tas ir atspoguḷots dažādos konstitūcijas noteikumos par ekonomiskajām, sociālajām un kultūras tiesībām, kā arī pilsoniskajām un politiskajām tiesībām, valsts un sabiedrības attiecībām, sociālo palīdzību un sociālo drošỉbu, valsts ekonomiskās darbības regulēšanas un organizēěanas principiem, valsts institūciju organizāciju un darbību u.c. (Constitutional Court of the Republic of Lithuania, 2004; Constitutional Court of the Republic of Lithuania, 2012). Arī Itālijas konstitūcijā sociāli atbildīgas valsts princips nav
4 Jāatzimēe, ka valsts var arì 4 ratificèt nevis visu Eiropas Sociālo hartu, bet noteiktu skaitu tās pantu.

5 1922. gada Satversmes II dalas projekta 107. panta otrais teikums: «Valsts un pašvaldỉbas iestāǎu uzturētās obligatoriskās mācỉbu iestādēs māciba visiem skolēniem bez maksas un trūcgu vecāku bërniem bez tan briva ari bariba, apgeêrbs un mācības lïdzeklị.» minēts tieši, taču konstitūcija uzliek valstij pienākumu nodrošināt plašu sociālo un ekonomisko tiesību klāstu. Turklāt tās 2. pants paredz valstij pienākumu nodrošināt politisku, ekonomisku un sociālu solidaritāti, bet 3. pants - pienākumu likvidēt visus ekonomiskos un sociālos škēeršlus, kuri, ierobežojot pilsoṇu brīiibu un vienlīdzỉbu, kavē pilnīgu individa attīstïbu un strādājošo līdzdalību valsts politiskajā, ekonomiskajā un sociālajā organizācijā (Constitutent Assambley, 1947).

Starptautiskā līmenī sociāli atbildīgas valsts ideja guva nostiprinājumu 20. gadsimtā. 1919. gadā tika nodibināta Starptautiskā Darba organizācija. Tã jau ir pienēmusi gandrīz 200 konvencijas, kas noteic dalībvalstu pienākumus tādās jomās kā darba apstākḷi, darba līgumu slēgšana, arodbiedrību brīvī-

ba, sociālā drošỉba u. tml. (International Labour Organization, n. d.). 1948. gadā tika pienemta ANO Vispārējā cilvēktiesību deklarācija, kurā ir ietvertas arī ekonomiskās, sociālās un kultūras tiesības (United Nations, 1948). Savukārt 1966. gadā tika pieṇemts ANO Starptautiskais pakts par ekonomiskajām, sociālajām un kultūras tiesībām, un no tā dalībvalstīm izriet dažādi pienākumi ekonomisko, sociālo un kultūras tiesību jomā (United Nations, 1966). Pašlaik paktu ir ratificējušas 165 valstis (The Office of the United Nations High Commissioner for Human Rights, n. d.). Eiropas limenī 1961.gadā tika pieṇemta Eiropas Sociālā harta, kuru ratificēja 27 valstis (Council of Europe, 1961), ${ }^{4}$ savukārt 1996. gadā tika pieṇemta Pārskatītā Eiropas Sociālā harta, kuru ir ratificējušas jau 34 valstis (Council of Europe, 1996).

SOCIĀLI ATBILDīGAS VALSTS IDEJAS VĒstURISKĀ ATTīstība LATVIJĀ Pirmajā neatkarības posmā ne pagaidu satversmēs, ne arī 1922. gadā pienemtajā Latvijas Republikas Satversmē nebija noteikts, ka Latvija ir sociāli atbildīga valsts (Kovalıevska, 2013, 257.lpp.). Latvijas Republikas Satversme šajā posmā nesaturēja arī tādas normas, no kurām varētu izsecināt, ka valstij ir konstitucionāls pienākums īstenot sociāli atbildīgas valsts ideju. Atškiirībā no Vācijas 1919. gada konstitūcijas pat Latvijas Republikas Satversmes II nodaḷas «Pamatnoteikumi par pilsoṇu tiesībām un pienākumiem» projektā, kurš netika pieņemts un līdz ar to nestājās spēkā, nebija iekḷauts plašs sociālo un ekonomisko tiesību klāsts. Ar sociāli atbildīgas valsts ideju varētu saistīt vienīgi projekta normas, kuras paredzēja, ka Latvijas pilsoṇu fiziskais un garīgais darbs un viṇu ražojumi atrodas valsts aizsardzībā, ka valsts nodrošina bezmaksas izglììibu lìdz 18 gadu vecumam, kā arī to, ka valsts un pašvaldību uzturētās mācību iestādēs trūcīgu vecāku bērniem bez maksas jānodrošina ēdiens un apgoèrbs. ${ }^{5}$

Lai arī pirmajā neatkarības posmā Latvijā konstitucionāli nebija nostiprināts pienākums īstenot sociāli atbildīgas valsts ideju, tomēr konceptuāli š̄i 
ideja tika atbalstīta. Piemēram, profesors Kārlis Dišlers norādīja, ka viens no valsts uzdevumiem ir «pacelt kultūru un veicināt tautas labklājību ar pozitīvu darbību» (Dišlers, 2004, 30.lpp.). Savukārt deputāts Kārlis Dēḳens, diskutējot par Latvijas Republikas Satversmes II nodalas projektu, norādīja: «Obligatoriska mācība nav nodrošināta, ja trūcīgo vecāku bērniem nav garantēta barība, apg̛ērbs un mācību līdzekḷi. Bērns nevar apmeklēt skolu, ja vinamam nav apavu. Ja nav ko mugurā vilkt, nav ko ēst, tad bērns nevar skolu apmeklēt [..].» (Latvijas Satversmes Sapulces, 2006, 60o.lpp.) Tādējādi deputāts pēc būtības atbalstijja ideju, ka ir nepieciešams nodrošināt to, lai personām faktiski būtu vienlīdzịgas iespējas realizēt savas tiesības. Arī valsts ìstenotā politika atbilda sociāli atbildīgas valsts idejai, jo šajā laikā tika pienemti likumi par sociālo palīdzību, sociālo nodrošināšanu un sociālo apdrošināšanu (Kovaḷevska, 2013, 257.lpp.). Latvijas Republika pirmajā neatkarības periodā pienēma vairākus likumus darba tiesību un darba aizsardzỉbas jomā, kā arī ratificēja vairākas Starptautiskās Darba organizācijas konvencijas darba tiesību un sociālā nodrošinājuma jomā (Mucenieks, 1934, 18.-21., 26.lpp.). Savukārt tiesu praksē tika atzîts tāds sociāli atbildīgas valsts principa elements kā vājāko aizsardzība (Strupišs, 2015, 45.lpp.).

Posmu pēc neatkarības atjaunošanas var iedalìt trīs dạ̣ās-1) no neatkarỉbas atjaunošanas lïdz 1998. gada 5. novembrim, 2) no 1998. gada 6. novembra līdz 2014. gada 21. jūlijam, 3) no 2014. gada 22. jūlija lïdz šim brīdim. Pirmajā posmā Latvijas Republika turpināja realizēt sociāli atbildīgas valsts idejai atbilstošu politiku. To apliecina, piemēram, tas, ka tika pieņemti likumi par sociālo aizsardzību (Koval̦evska, 2013, 259.lpp.). Šajā posmā konstitucionālā līmenī joprojām nebija tieši noteikts, ka Latvija ir sociāli atbildīga valsts. Tomēr ir iespējams argumentēt, ka Latvijas Republikai jau šajā posmā bija konstitucionāls pienākums īstenot sociāli atbildīgas valsts idejai atbilstošu politiku. 1990. gada 4. maijā tika atjaunota Latvijas Republikas Satversmes 1. panta darbība (Augstākā Padome, 1990a). Šis pants noteica, ka Latvija ir neatkarīga, demokrātiska republika. 199o. gada 4. maijā Latvijas Republika arī atzina sev par saistošiem daudzus cilvēktiesību dokumentus, tostarp ANO Vispārējo cilvēktiesību deklarāciju un ANo Starptautisko paktu par ekonomiskajām, sociālajām un kultūras tiesībām (Augstākā Padome, 199ob). 1991. gada 10. decembrì tika pieņemts konstitucionālais likums «Cilvēka un pilsona tiesības un pienākumi», kurā bija ietverts arī plašs sociālo un ekonomisko tiesību katalogs (Augstākā Padome, 1992). 20. gadsimta 90. gados modernu Rietumu tipa demokrātisku valsti raksturoja tas, ka tā ievēro cilvēktiesības. Turklāt mūsdienu Eiropā demokrātiskas valstis parasti vismaz minimālā apmērā rūpējas par cilvēka cienīgu dzìves līmeni, sociālo apdrošināšanu, vājāko aizsardzību un citiem tamlīdzīgiem jautājumiem. Tas lielā mērā ir saistîts ar cilvēktiesību standartu attīstìbu, kas prasa valstīm nodrošināt arī ekonomiskās, sociālās un kultūras tiesības (Kovalevska, 2008; Pleps,
6 «1918. gada 18. novembri proklamētā Latviijs valsts ir izveidota, [.] lai [.] nodrošinātu Latvijas tautas un ikviena brivibu un sekmētu labkläjibu.»
Pastars, \& Plakane, 2014, 147.lpp.). Lỉdz ar to var secināt, ka no Latvijas Republikas Satversmes 1. panta kopsakarā ar Latvijas Republikas uzṇemtajām starptautiskajām saistībām un konstitucionālajā likumā «Cilvēka un pilsoṇa tiesības un pienākumi» noteiktajiem pienākumiem izrietēja tas, ka Latvijas Republikai jau 20. gadsimta 9o. gados bija konstitucionāls pienākums ievērot sociālās un ekonomiskās tiesības (Grigore-Bāra u.c., 2014, 174.-177.lpp.; Kūtris, 2009; Konstitucionālo tiesību komisija, 2012, 141. punkts; Levits, 2013, 93. lpp.; Augstākā tiesa, 2008, 9. punkts). Tātad Latvijas Republikai bija arī konstitucionāls pienākums istenot sociāli atbildīgas valsts idejai atbilstošu politiku. Tas nozīmē, ka jau šajā posmā sociāli atbildīgas valsts principam Latvijā bija konstitucionāls rangs.

1998. gada 15. oktobrī tika pieñemti un 1998. gada 6. novembrī stājās spēkā grozijjumi Latvijas Republikas Satversmē, ar kuriem Latvijas Republikas Satversme tika papildināta ar vIII nodalu «Cilvēka pamattiesības» (Saeima, 1998). Tā kā šajā nodalāā ir iekḷauts arī plašs sociālo un ekonomisko tiesỉbu klāsts, tad no 1998. gada 6. novembra Latvijas Republika nepārprotami piederēja pie to valstu loka, kurās sociāli atbildīgas valsts principam bija konstitucionāls rangs. Šajā posmā arī Satversmes tiesa pirmo reizi tieši norādīja, ka Latvija ir sociāli atbildīga valsts. Satversmes tiesa 2006. gada 2. novembra spriedumā lietā Nr. 2006-07-01 secināja: «Latvijas konstitucionālais likumdevējs Satversmē noteicis virkni sociālo tiesību. Tādējādi likumdevējs noteicis, ka Latvija ir sociāli atbildīga valsts, proti, tāda valsts, kas likumdošanā, pārvaldē un tiesas spriešanā cenšas iespējami plaši ìstenot sociālo taisnīgumu. Sociāli atbildīgas valsts mērkis ir sabiedrībā izlīdzināt būtiskākās sociālās atšķiirības un katrai iedzìvotāju grupai nodrošināt atbilstošu dzives standartu.» (Satversmes tiesa, 2006b, 18. punkts) Jāatzimēe gan, ka arī pirms šì sprieduma Satversmes tiesas spriedumos bija iedzivināti sociāli atbildīgas valsts principa elementi, lai arī spriedumos sociāli atbildīgas valsts princips tieši minēts nebija (Kovalıevska, 2008).

Pēdējo attīstības posmu ievadỉja tas, ka 2014.gada 22. jūlijā stājās spèkā grozijumi Latvijas Republikas Satversmē, ar kuriem tika izvērsts Latvijas Republikas Satversmes ievads (Saeima, 2014). Latvijas Republikas Satversmes ievada 4.rindkopā ir noteikts: «Latvija kā demokrātiska, tiesiska, sociāli atbildīga un nacionāla valsts balstās uz cilvēka cienu un brīvỉbu, atzīst un aizsargā cilvēka pamattiesības un ciena mazākumtautības.» Līdz ar to no 2014. gada 22. jūlija Latvija pieder pie to valstu loka, kurās konstitūcijā jau ir tieši noteikts, ka attiecīgā valsts ir sociāli atbildīga valsts. Ar sociāli atbildīgas valsts principu ir saistīts arī Latvijas Republikas Satversmes 1.rindkopā minētais valsts pienākums sekmēt labklājỉbu. ${ }^{6}$ Kā ir norādījusi Satversmes tiesa, no sociāli atbildīgas valsts principa izriet valsts pienākums izveidot ilgtspējīgu un sabalansētu politiku sabiedrības labklājības nodrošināšanai (Satversmes tiesa, 
2010b, 22.punkts). Savukārt ievada 4. un 5.rindkopā ir ietverti koncepti, uz kuriem balstās sociāli atbildìgas valsts ideja - cilvēka cieņa, taisnīgums, vienlīdziba un solidaritāte. ${ }^{7}$

Sociāli atbildīgas valsts principa kontekstā nozīmīgs ir arī Latvijas Republikas Satversmes ievada 5.rindkopā noteiktais, ka «[i]kviens rūpējas par sevi, saviem tuviniekiem un sabiedrïbas kopējo labumu, izturoties atbildīgi pret citiem, nākamajām paaudzēm, vidi un dabu». No vienas puses, šajā

teikumā ietvertais pienākums rūpēties par sabiedrības kopējo labumu atspoguḷo solidaritātes ideju, uz kuras balstās sociāli atbildīgas valsts princips, proti, cilvēku savstarpējo saistību un līdz ar to arī pienākumu cits citam palīdzēt. No otras puses, šajā teikumā norādìtais, ka cilvēkam ir pienākums rūpēties pašam par sevi un tuviniekiem, atspoguḷ subsidiaritātes principu un iezīmē sociāli atbildīgas valsts principa robežas. Subsidiaritātes princips palīdz nodrošināt lïdzsvaru starp brīvỉbu un vienlīdzìbu sociāli atbildīgā valstī, jo valsts aktīvā darbība sociālo atšķirìbu izlīdzināšanā vienlaikus gan sekmē personas brīiību, gan arī ierobežo to. Sociāli atbildīgas valsts princips prasa nodrošināt iespēju vienlïdzību, tādējādi sekmējot personas brīvỉbu realizāciju. Taču sociāli atbildīgas valsts princips arī ierobežo personas brīibu, jo palīdzíba personai var tikt sniegta, pieprasot no personas pretī arì kāda konkrēta pienākuma izpildi. Tāpat sociāli atbildīgas valsts princips var pamatot vienu personu tiesību ierobežošanu, lai nodrošinātu aizsardzību citām - vājākām personām (Maurer, 2007, S. 235-236). Subsidiaritātes princips nosaka to, ka arī gadijumos, kad briviibas istenošanai ir nepieciešama valsts palīdzība iespēju vienlīdzības nodrošināšanā, primārai jābūt personas pašas atbildībai par sevi un savas dzives apstākḷiem (Hufen, 2007, S. 8-9), tādējādi samazinot to gadijumu skaitu, kad valstij ir pienākums iejaukties. Personas pašas atbildību par primāro atzina gan Lorencs fon Šteins 19. gadsimtā, gan arī Satversmes tiesa 21. gadsimtā, norādot, ka mūsdienu valstij jāspēj rūpēties par sociālo taisnìgumu, cilvēka cienīgiem dzìves apstākḷiem un vispārējo labklājību, saglabājot pēc iespējas plašu darbibas telpu radošai personības attīstibai (Satversmes tiesa, 2006c, 13.3. punkts).

\section{Sociāli atbildīgas valsts} principa saturs

SOCIĀLI ATBILDĪGAS VALSTS PRINCIPA ELEMENTI UN VALSTS PIENĀKUMI SOciāli atbildigas valsts princips tiek skaidrots dažādi. Tiek arī norādīts, ka tā saturs ir visai neskaidrs (Roca, 2012-2013, p. 216; Maunz \& Dürig, 2014, S. 7). Tomēr, izanalizējot juridiskajā literatūrā izteiktos viedokḷus, kā arì Satversmes tiesas nolēmumus, var secināt, ka Latvijas Republikā sociāli atbildīgas valsts princips ietver sevī šādus četrus elementus: 1) valsts pienākumu nodrošināt cilvēka cienīgas eksistences minimālos priekšnoteikumus, 2) valsts pienākumu nodrošināt aizsardzību sociāla riska gadījumā, 3) valsts pienākumu rūpēties par sociālo taisnīgumu, 4) cilvēka saistību ar sabiedrïbu (Kovalevska, 2008).

Sociāli atbildīgas valsts princips uzliek pienākumus visiem trīs valsts varas atzariem (Satversmes tiesa, 2006b, 18. punkts). Primārā atbildỉba par šā principa realizāciju ir likumdevējam, kam normatîvajos aktos jākonkretizē sociāli atbildīgas valsts princips. Likumdevējam jānoteic, kam, kādos apstāklos un kāda veida sociālā palīdzỉba pienākas, kā darbojas sociālās apdrošināšanas sistēma, kādās nozarēs un ar kādiem līdzekḷiem tiek aizsargātas vājākās personas, kā notiek sociālo atšḳirību izlīdzināšana u. tml. Likumdevējs nevar aprobežoties tikai ar sociālā nodrošinājuma jomu, jo sociāli atbildīgas valsts princips darbojas arī civiltiesībās, procesuālajās tiesībās, sodu izpildes tiesībās, izglìiibas tiesībās, nodokḷu tiesībās u. c. (Maurer, 2007, S. 232). Sociāli atbildīgas valsts princips uzliek pienākumu likumdevējam rūpēties par noteiktu mērku sasniegšanu, taču šis princips nenosaka precīzi, ar kādiem līdzekḷiem šie mērḳi ir sasniedzami. Līdz ar to likumdevējam ir plaša rīcības brīvība, kuru var ietekmēt arī pieejamo resursu daudzums (Maunz \& Dürig, 2014, S. 11). Taču jāatceras, ka likumdevēja rīcības brīivibas robežas nosaka Latvijas Republikas Satversme un Latvijas starptautiskās saistības.

Arī izpildvarai un tiesu varai ir zināma atbildība par sociāli atbildīgas valsts principa îstenošanu. Izpildvarai un tiesu varai šis princips jāizmanto tiesību normu interpretācijā un piemērošanā (Roca, 2012-2013, p. 217; SchmidtBleibtreu \& Klein, 1995, S. 512). İpaši nozīmīgs šis princips var būt situācijās, kad valsts pārvaldei ir pieškirta rīcibas brīviba un jāapsver lietderība vai kad ar saturu jāpiepilda nenoteiktais tiesību jēdziens (Maurer, 2007, S. 233).

Visiem valsts varas atzariem ir jāṇem vērā arī tas, ka sociāli atbildīgas valsts darbïbai jānorit atbilstoši tiesiskas valsts principam, ievērojot cilvēktiesības, tiesisko vienlīdzïbu, samērīguma principu un procesuālo taisnìgumu (Maurer, 2007, S. 236-237; sk. arī Kūtris, Ķinis \& Osipova, 2012, 5. punkts).

Attiecībā uz to, vai no sociāli atbildígas valsts principa izriet arī indivìda subjektīvās tiesības prasìt no valsts konkrētu rīcību, vācu juridiskajā literatūrā tiek atbildēts noliedzoši (Jarass \& Pieroth, 2007, S. 506; Maurer, 2007, S. 233; Sodan \& Ziekow, 2007, S. 78). Kā izṇēmums tiek norādìts tas, ka persona ir subjektīvas tiesības prasīt nodrošināt eksistencei nepieciešamo minimumu, taču arī šajā iznēmuma gadījumā subjektīvās tiesības rada sociāli atbildīgas valsts princips kopsakarā ar cilvēka cieņas nodrošināšanas principu (Sodan \& Ziekow, 2007, S. 80). Latvijā šim jautājumam nav lielas praktiskas nozimes, jo Latvijas Republikas Satversmē ir nostiprināts plašs ekonomisko, sociālo un kultūras tiesību klāsts, kas rada individam arī noteiktas subjektīvas tiesības pret valsti. Līdz ar to Latvijā indivīds var prasīt noteiktu, no sociāli atbildīgas valsts principa izrietošu valsts pienākumu izpildi, balstoties uz konkrētām cilvēktiesību normām. 
CILVĒKa CIENíGas eKSISTENCES MINIMĀLIE PRIEKŠNOTEIKUMI Viens no sociāli atbildīgas valsts principa elementiem ir valsts pienākums nodrošināt cilvēka cienīgas eksistences minimālos priekšnoteikumus, kas ietver sociālās palīdzības sniegšanu, pamatpakalpojumu nodrošināšanu, kā arī izglìtības, veselības un sociālās aprūpes, kultūras iestāžu pieejamības nodrošināšanu (Kovaḷevska, 2008).

Šis sociāli atbildīgas valsts principa elements ir cieši saistits ar dažādām cilvēktiesībām. Pirmkārt, tas ir cieši saistits ar ANo Vispārējās cilvēktiesību deklarācijas 25. pantā un ANo Starptautiskā pakta par ekonomiskajām, sociālajām un kultūras tiesībām 11. pantā ietvertajām tiesībām uz atbilstošu dzìves lïmeni. Šie panti garantē personai tiesības uz viṇas un viņas ǵimenes veselības uzturēšanai un labklājibai atbilstošu dzives līmeni, ieskaitot uzturu, apǵêrbu, mājokli, medicīnisko aprūpi un nepieciešamos sociālos pakalpojumus. Otrkārt, tiesības uz sociālo palīdzību izriet no Latvijas Republikas Satversmes 109. pantā un ANO Starptautiskā pakta par ekonomiskajām, sociālajām un kultūras tiesībām 9. pantā garantētajām tiesībām uz sociālo drošību jeb sociālo nodrošinājumu. Savukārt pienākums nodrošināt izglìīibas, veselības un sociālās aprūpes, kultūras iestāžu pieejamību izriet attiecīgi no tiesībām uz izglìitību, tiesībām uz veselību, tiesībām uz sociālo nodrošinājumu un tiesībām piedalīties kultūras dzīvē (Committee on Economic, Social and Cultural Rights, 1999, para. 6; Committee on Economic, Social and Cultural Rights, 2000, para.12; Committee on Economic, Social and Cultural Rights, 2009, para. 16).

Valsts pienākuma - nodrošināt cilvēka cienīgas eksistences minimālos priekšnoteikumus - kontekstā problemātisks ir jautājums, kas tieši ietilpst šajos minimālajos priekšnoteikumos. Absolūtais minimums būtu pārtika, apg̛ērbs, mājoklis un medicīniskā palīdzība, kas nepieciešami elementāras izdzivošanas garantēšanai jebkuram cilvēkam. Pie šĩ minimuma būtu pieskaitāma arī pamatizglìtỉbas nodrošināšana (Konstitucionālo tiesību komisija, 2012, 317. punkts). Taču ar cilvēka cienigas eksistences minimālajiem priekšnoteikumiem nedriksstētu saprast tikai apstākḷus, kas nepieciešami vienigi «kailai izdzìvošanai» (Vildbergs, Messeršmits, \& Niedre, 2004, 123.lpp.). Satversmes tiesa ir skaidrojusi, ka sociālās drošỉbas pasākumiem ir ne tikai ekonomiskā funkcija - aizstāt ienākumu zudumu, bet arī sociālā funkcija nodrošināt indivìdu iespējas saglabāt pilnvērtīga sabiedrības locekḷa statusu (Satversmes tiesa, 2002, secinājumu dalas 3.1.3. punkts; 2004b, 7. punkts). Pilnvērtīga sabiedrības locekḷa statusa saglabāšanai kalpo, piemēram, valsts pienākums nodrošināt pieeju kultūras iestādēm. Lìdz ar to arī sociālajai palīdzībai būtu jābūt tādai, lai persona, pirmkārt, varētu nodrošināt sev un savai ğimenei pārtiku, apğērbu, mājokli un medicīnisko palīdzību, kas nepieciešami elementāras izdzīvošanas garantēšanai jebkuram cilvēkam, kā arī pamatizglìīibu. Otrkārt, sociālajai palīdzībai būtu jālauj arī saglabāt personai pilnvērtiga sabiedrïbas locekla statusu.
Līdz šim nav izstrādāta viena pasaulē vispāratzìta metode, kā noteikt, vai valsts sniegtā sociālā palīdzība atbilst šìm prasībām. Atbilstoši Satversmes tiesas norādītajam, lai noskaidrotu, kāds konkrētajā gadījumā ir sociālā nodrošinājuma minimālais līmenis, valstij jāizvēlas starp vairākām metodēm, ko lieto dažādas starptautiskās organizācijas. Izvēle par labu noteiktai metodei ir atkarīga no izpratnes par vērtībām un apsvērumiem par mājsaimniecỉbu patērina minimālajām vajadzībām. Šie apsvērumi ietekmēs rezultātus. Izvēloties konkrētu metodi, ir svarīgi apzināties tās potenciālo ietekmi uz nevienlīdzību un nabadzību, nabadzìgo iedzīvotāju skaitu un sastāvu. N̦emot vērā to, ka rezultāti var atšḳirties atkarībā no izraudzītās metodes, tieši Latvijas situācijai vispiemērotākās metodes argumentēta izvēle ir likumdevēja politiskās izškiršanās jautājums (Satversmes tiesa, 2009b, 31.2. punkts).

Šì atziṇa rada jautājumu, vai likumdevējam šajā ziṇā ir neierobežota rīcības brīvỉba un vai likumdevēja veikto izvēli var paklaut kādai pārbaudei. Diemžēl Satversmes tiesas nolēmumi nedod skaidru atbildi uz šo jautājumu. Taču, piemēram, Vācijas Federālā Konstitucionālā tiesa ir atzinusi: lai arī likumdevēja prerogatīva ir noteikt minimālo pabalstu un pensiju apmēru un likumdevējam ir rīcības brīibiba, tomēr tiesa var pārbaudīt: 1) vai likumdevējs, nosakot minimālo apmēru, ir izvērtējis to, ka mērḳim ir jābūt cilvēka cienīgas eksistences nodrošināšanai; 2) vai likumdevējs ir izvēlējies pēc būtības piemērotu metodi iztikas minimuma noteikšanai; 3) vai likumdevējs ir pilnīgi un korekti ieguvis metodes piemērošanai nepieciešamos faktus; 4) vai likumdevējs ir rīkojies konsekventi un visās aprēḳina stadijās ir ievērojis izvēlēto metodi un tās strukturālos principus. Turklāt likumdevējam ir jāsniedz detalizēta informācija un skaidrojums par aprēkiniem. Ja likumdevējs to nespēj pienācīgi izdarìt, tad noteiktais pabalstu un pensiju apmērs nav atbilstošs konstitūcijai (Vācijas Federālā konstitucionālā tiesa, 2010, 143.-144. punkts).

Lai nodrošinātu cilvēka cienīgas eksistences minimālos priekšnoteikumus, valstij ir tiesības arī ierobežot citu personu tiesības. Satversmes tiesa, piemēram, ir norādījusi, ka valstij ir tiesības pienemt likumus, ko tā uzskata par nepieciešamiem, lai kontrolētu ippašuma izmantošanu saskanāa ar vispārējām interesēm. Šādi likumi ir îpaši vajadzịgi mājokḷu jomā, kura mūsdienu sabiedrībā ir nozīmīga sociālās un ekonomiskās politikas sastāvdaḷa (Satversmes tiesa, 2014, 22. punkts). Dzìvoklu tiesību jomā svarīgs ir cilvēku sociālās aprūpes elements. Lìdz ar to, ievērojot sabiedriskās intereses, telpu îres tiesības iegūst ne vien privātu, bet arī publisku tiesību raksturu, un normatīvie akti var paredzēt noteiktus īpašuma tiesību ierobežojumus dzivojamo telpu izīrētājiem (Satversmes tiesa, 1999, secinājumu dalas 5.punkts). Tāpat Satversmes tiesa atzinusi, ka valsts ir tiesīga ierobežot īres maksas apmēru, lai aizsargâtu trūcīgos un maznodrošinātos îrniekus apstākḷos, kad pastāv lētu dzivojamo telpu trūkums (Satversmes tiesa, 2006a, 15.4. punkts). Savukārt 
citā lietā Satversmes tiesa vērtēja tiesību normu, kura noteica, ka tām personām, kuru mācības rezidentūrā finansē valsts, ir pienākums trīs gadus pēc rezidentūras beigšanas strādāt noteiktās ārstniecības iestādēs vai atmaksāt to apmācībai izlietotos valsts budžeta līdzeklus. Satversmes tiesa konstatēja, ka šāda kārtība noteikta, lai valsts spētu nodrošināt vienlīdzigu veselības aprūpes pakalpojumu pieejamību visā valsts teritorijā, un atzina, ka ir piel̦aujams šādā veidā ierobežot ārstu tiesības brīvi izvēlēties darbavietu (Satversmes tiesa, 2012c).

Tomēr valsts pienākums rūpēties par cilvēka cienīgas eksistences minimālo priekšnoteikumu nodrošināšanu nenozīmē to, ka valstij ir jāuzṇemas pilnīga atbildỉba par personu un tās aprūpi. Satversmes tiesa, atsaucoties uz profesoru Reinholdu Cipeliusu (Reinhold Zippelius), ir norādijusi, ka cilvēkā slēpjas ar pašcieṇu cieši saistita vajadzība pēc patstāvỉbas, ka cilvēks vairāk bauda paša iegūto nekā pieškiirto un ka totāla aprūpe ir pretēja cilvēka dabai (Satversmes tiesa, 2006c, 13.3. punkts). Arī Augstākā tiesa ir norādījusi, ka valsts un pašvaldības pienākums palīdzēt personai pastāv tiktāl, ciktāl persona pati vai personas, kas var tai palīdzēt, nespēj personu pietiekami nodrošināt. Valsts un pašvaldỉbas sniegta sociālā palīdzība vienmēr ir tikai subsidiārs sociālā atbalsta avots. Tās visupirms ir pašas personas tiesības un reizē arī pienākums - veidot savu dzīvi un labklājỉbu, gādāt par saviem bērniem, saviem vecākiem. Valsts kā personu juridiskās organizācijas forma jau savos pamatos pastāv tādēl, lai sniegtu atbalstu iedzivotājiem tajos jautājumos, ar ko individuāli vai mazākās organizētās kopībās sabiedrība pati netiek galā (Augstākā tiesa, 2011a, 8. punkts). Šìs tiesu atzinas spilgti ilustrē Latvijas Republikas Satversmes ievada 5.rindkopā ietverto subsidiaritātes principu un no tā izrietošo cilvēka pienākumu rūpēties pašam par sevi un tuviniekiem.

Balstoties uz šīm atzinām, Augstākā tiesa ir atzinusi, ka iespēja sanemt palīdzību no tuviniekiem var būt pamats atteikumam piešḳirt sociālo palīdzību. Piemēram, kādā lietā Augstākā tiesa secināja: tas, ka pieteicēja saṇem atbalstu no sava dēla, var būt pamats atteikumam piešḳirt maznodrošinātas personas statusu (Augstākā tiesa, 2011a, 8. punkts). Tāpat personai var atteikt piešḳirt palīdzību dzīvokḷa jautājuma risināšanā, ja persona lieto dzīvokli viṇas dēliem piederošā īpašumā, jo personai šādā gadijjumā pašvaldības palīdzība dzīvokla jautājuma atrisināšanai nav nepieciešama (Augstākā tiesa, 2011b, 10. punkts). Augstākā tiesa ari ir atzinusi: tas, ka bērnu vecākiem pieder nekustamais īpašums, var būt pamats, kāpēc pašvaldība atsaka sociālās palīdzības pieškiršanu g̛̣imenei. Par bērniem primāri ir jārūpējas tām personām, kuras bērnus ir radījušas, tas ir, vecākiem. Tā ir ğimenes attiecỉbu aksioma, kas nav tālāk iztirzājama (Augstākā tiesa, 2010b, 9. punkts).

Tiesu praksē ir atzìts arī tas, ka cilvēkam ir pienākums rūpēties par sevi. Lìdz ar to personai piederošs īpašums, piemēram, zeme, mežs vai ēkas, var būt šḳērslis sociālās palīdzības sanemšanai. Tomēr tiesas ir arī norādījušas, ka pašvaldỉbu saistošajos noteikumos ietverto normu par īpašumu kā šķērsli sociālās palīdzības saṇemšanai nevar tulkot tikai gramatiski, jo īpašumam arī faktiski ir jābūt tādam, kurš var dot papildu ienākumu (Administratĩvā apgabaltiesa, 2013a, 12. punkts; 2013b, 10. punkts) vai kuru var citādā veidā izmantot savu pamatvajadzību nodrošināšanai

Piemēram, kādā lietā tiesas atzina: tas, ka persona tika apstiprināta mantojuma tiesībās uz vienu pusi domājamās dalas no trīsistabu dzivokḷa (tā kadastrālā vērtība bija 954 lati un 17 santīmi), nevar būt pamats, lai personai liegtu palīdzību dzivokḷa jautājuma risināšanā. Konkrētajā gadỉjumā dzīvoklis bija izdemolēts, divām istabām bija izlauztas durvis ar visām eņgóēm, logi bija aizsisti ar dẹliem, vannas istabā nebija vannas, virtuvē bija izjaukta plīts, dzīvoklis nebija apkurināms, jo centrālā apkure nedarbojās un radiatori bija iznnemti. Lìdz ar to tiesas ieskatā, lai šo dzivokli padarītu par dzīvošanai derīgu, būtu nepieciešams izveidot autonomu apkures sistēmu (krāsni ar skursteni), virtuvē pārbūvēt plīti, vannas istabā ierìkot higiēnas prasībām atbilstošu tualetes podu un dušu vai vannu, un, tā kā ir atslēgta elektrība un ūdens, būtu jānodrošina arī šo pamatpakalpojumu pieslēgšana. Tiesas norādỉja, ka visi iepriekš minētie pasākumi acīmredzami prasa tādus ieguldijjumus, kādu konkrētajai personai nav. Proti, tie ir nesamērīgi lieli ar tāda cilvēka ienākumiem, kuram nekas cits nepieder, kurš vēl mācās skolā, dzīvo pie aizbildṇa un kuru uztur aizbildnis. N̦emot vērā dzivokḷa zemo kadastrālo vērtỉbu, tiesa secināja, ka dzīvokḷa izremontēšanai nepieciešamos lỉdzekḷus personai nav arì iespējams iegūt kā bankas aizdevumu, jo ar šādu dzīvokli nav iespējams nodrošināt kredītsaistības. Lìdz ar to tiesa atzina, ka pašvaldībai ir pienākums reǵistrēt personu palidzības saṇemšanai dzīvojamās telpas izīrēšanai (Administratīvā rajona tiesa, 2012; Administratīvā apgabaltiesa, 2012).

Ja personai pieder ipašums, tad tai ir pienākums aktīi līdzdarboties sava materiālā stāvokḷa uzlabošanā un tā nevar gaidīt atbalstu no sabiedrības, jo sociālā palīdzība ir sniedzama tikai situācijās, kad personām nav citas iespējas pašām nodrošināt savu pamatvajadzību îstenošanu. Līdz ar to citā lietā tiesa, konstatējot, ka pieteicējas ǵimenei pieder zemesgabali, kuriem bija gan materiālā vērtība (tuvu Rīgai, ir būvniecības iespējas, kopējā kadastrālā vērtība pārsniedza 5000 latus), gan arī apsaimniekošanas vērtība (piemēram, izmantošana dārzkopībai), un pieteicējas ğimene, pieliekot attiecīgas pūles, tādā vai citādā veidā varēja gūt no šiem îpašumiem ienākumus, atzina, ka šai ğimenei nav tiesību sanemt sociālo palīdzību (Administratîvã apgabaltiesa, 2013a, 14. punkts)

Tiesas ir arī atzinušas, ka nav nozīmes tam, vai persona reāli izmanto tai piederošos îpašumus ienākumu gūšanai, jo tikai no pašas personas griba un rīcības ir atkarīgs tas, kā vina izmanto vai neizmanto to labumu, ko var 
gūt no îpašuma. İpašnieka gribas trūkums izmantot īpašumu nevar būt par pamatu secinājumam, ka īpašums ienākumu gūšanai nav izmantojams. Līdz ar to tiesa secināja, ka personai nav sniedzama sociāā palīdzība, jo tai piederošos zemesgabalus var nodot lietošanā par atlīdzỉbu citai personai vai arī tos var atsavināt, iegūto naudu izmantojot savu dzives apstākḷu uzlabošanai (Administratīiāa apgabaltiesa, 2013d, 16. punkts).

Tātad sociāli atbildīgas valsts princips ir jāinterpretē kopsakarā ar cilvēka pienākumu rūpēties pašam par sevi un tuviniekiem. Lìdz ar to sociāli atbildīgas valsts princips neliedz valstij prasìt no personas aktīvu iesaistīšanos savu sociālo problēmu risināšanā, tostarp līdzdarbību, ja persona vēlas sanemt sociālo palīdzību. Taču, tā kā no cilvēka cienas principa izriet nepieciešamỉba dot personai iespēju apgādāt pašai sevi un nebūt atkarīgai no valsts sniegtās palīdzības, tad valsts nedrīkst pati veikt un piel̦aut, ka citi veic no personas algas, pensijas vai cita veida ienākumiem ieturējumus tādā apmērā, ka personas rīcībā nepaliek pamatvajadzỉbu apmierināšanai nepieciešamie lïdzekḷi (Kovaḷevska, 2009). Tas attiecas arī uz nodokḷiem. Piemēram, Vācijas Federālā konstitucionālā tiesa ir norādījusi, ka ar ienākuma nodokli nedrikst aplikt summu goimenes iztikas minimuma apmērā un nodoklu maksātājam pēc ienākuma nodokḷa nomaksas no viṇa ienākumiem ir jāpaliek tik daudz, lai viṇš varētu uzturēt sevi un savu ğimeni (Vācijas Federālā konstitucionālā tiesa, 1990, 104.-105. punkts; Vācijas Federālā konstitucionālā tiesa, 1992, 64. punkts).

Kā jau tika norādīts, valsts pienākums nodrošināt cilvēka cienīgas eksistences minimālos priekšnoteikumus ietver ne tikai pienākumu sniegt sociālo palīdzību, bet arī pienākumu nodrošināt pamatpakalpojumus un izglìīibas, veselības un sociālās aprūpes, kultūras iestāžu pieejamību. Ar pieejamības nodrošināšanu ir jāsaprot dažādi pieejamības aspekti, piemēram, finansiālā pieejamība un fiziskā pieejamība (Committee on Economic, Social and Cultural Rights, 1999, para.6; Committee on Economic, Social and Cultural Rights, 2000, para.12; Committee on Economic, Social and Cultural Rights, 2009, para.16).

Finansiālā pieejamība nozīmē to, ka ir jānodrošina, lai maksa par izglītību, veselības aprūpi un dalību kultūras dzìvē nebūtu nesamērīga salīdzinājumā ar personas ienākumiem (Committee on Economic, Social and Cultural Rights, 1999, para. 6; Committee on Economic, Social and Cultural Rights, 2000, para.12; Committee on Economic, Social and Cultural Rights, 2009, para.16). Lai to nodrošinātu, piemēram, Latvijas Republikas Satversmes 112.pantā ir noteikts, ka valsts nodrošina iespēju bez maksas iegūt pamatizglìïibu un vidējo izglìīibu.

Fiziskā pieejamība nozīmē to, ka attiecīgajām èkām ir jābūt tādām, lai arì visdažādākā vecuma personas un personas ar invaliditāti varētu ieklūt un pārvietoties tajās (Committee on Economic, Social and Cultural Rights, 1999, para. 6; Committee on Economic, Social and Cultural Rights, 2000, para. 12; Committee on Economic, Social and Cultural Rights, 2009, para.16). Piemēram, kādā lietā Augstākā tiesa atzina, ka, nenodrošinot personai, kas pārvietojas ratin krēslā, ieklūšanu ārstniecības iestādē, kur šì persona vēlējās sanemt ǵ̛imenes ārsta pakalpojumu, ir pieḷuta prettiesiska rīcība (Augstākā tiesa, 2010a) Fiziskā pieejamỉba nozīmē arī to, ka valsts attiecīgajām iestādēm jābūt personām sasniedzamām, t.i., vai nu sasniedzamā attālumā, vai arī sasniedzamām, izmantojot dažădas tehnoloǵijas (Committee on Economic, Social and Cultural Rights, 1999, para. 6; Committee on Economic, Social and Cultural Rights, 2000, para.12; Committee on Economic, Social and Cultural Rights, 2009, para.16). Līdz ar to no pienākuma nodrošināt izglītỉbas, veselības un sociālās aprūpes, kultūras iestāžu pieejamību, kā arī no pienākuma nodrošināt pamatpakalpojumus izriet valsts pienākums rūpēties par infrastruktūru, tostarp par celiem, sabiedriskā transporta sistēmu, ūdensapgādes un kanalizācijas sistēmu un elektroapgādes sistēmu (Schmidt-Bleibtreu \& Klein, 1995, S. 511; Maunz \& Dürig, 2014, S.10.).

Eiropas Savienības Tiesas tiesnesis un bijušais Eiropas Cilvēktiesību tiesas tiesnesis Dr.iur.h.c. Egils Levits ir norādīijis, ka no sociāli atbildīgas valsts principa izriet arī valsts pienākums nodrošināt augstvērtīgas informācijas infrastruktūru, kas sniedz individam iespējami objektivvu, plašu un dzilu informāciju par dažādām politiskajām, sociālajām un kultūras norisēm, lai individs varētu pilnvērtīgi piedalīties sabiedrības dzivē. Šādas informācijas pieejamìba ir būtiska, jo moderna sabiedrība un katrs individs ir eksistenciāli atkarīgs no tās. Ja augstvērtīgas informācijas piedāvājums kḷūst stipri ierobežots, tas apdraud gan visas sabiedrỉbas attīstību, tās globālo politisko un ekonomisko konkurētspēju, gan arī ierobežo potenciāli ieinteresētā indivìda intelektuālās iespējas (Levits, 2009).

AIZSARDZīBa SOCIĀLA RISKA GADījumā Pienākums nodrošināt aizsardzību sociāla riska gadỉjumā kā sociāli atbildīgas valsts principa elements ir nostiprināts Latvijas Republikas Satversmes 109. un 110. pantā, kuri garantē tiesības uz sociālo nodrošinājumu. Šie panti paredz valsts pienākumu nodrošināt sociālo aizsardzību vecuma, darbnespējas, bezdarba un citos likumā noteiktos gadījumos, kā ari īpašu aizsardzību ğimenēm un bērniem. Šajos pantos konstitucionāli ir nostiprinātas pamattiesības, kas saistītas ar sabiedrības locekḷu solidaritāti sociālajā jomā, jo sociālā nodrošinājuma shēmas ir sabiedrības un tās mazāk aizsargāto locekḷu solidaritātes izpausme (Satversmes tiesa, 2010c, 6.3. un 8. punkts). Proti, persona sociālā riska iestāšanās gadijumā saṇem sociālo aizsardzību parasti pensijas vai pabalsta veidā no līdzekḷiem, kurus nodrošina tobrīd strādājošās personas. Tādējādi personas îsteno Latvijas Republikas Satversmes ievada 5.rindkopā minēto pienākumu rūpēties par sabiedrības kopējo labumu. 
Tiesības uz sociālo nodrošinājumu Latvijā ir konkretizētas vairākos tiesību aktos, veidojot sociālā nodrošinājuma jeb sociālās drošības sistēmu, kas aptver plašu sociālā nodrošinājuma pasākumu un pakalpojumu klāstu. Sociālā nodrošinājuma sistēmas būtiskākās dalas ir valsts sociālā apdrošināšana, sociālā palīdzība un pakalpojumi un sociālais atbalsts, it ịpaši valsts sociālo pabalstu veidā. Aizsardzību noteiktu sociālo risku iestāšanās gadijjumā personai sniedz galvenokārt valsts sociālās apdrošināšanas sistēma. Kā ir skaidrojusi Augstākā tiesa, sociālās apdrošināšanas būtība ir apdrošināt personas risku zaudēt darba ienākumus saistībā ar sociālā riska jeb apdrošināšanas gadijjuma iestāšanos. Tas nozīmē, ka sociālās apdrošināšanas sistēmā personai tiek izmaksāts sociālās apdrošināšanas pabalsts, kas sedz dalu no personas gūtajiem ienākumiem, kādi tai bija sociālā riska iestāšanās brīdī un kurus tā nespēj iegūt sociālā riska iestāšanās dẹḷ (Augstākā tiesa, 2013a, 9. punkts; Augstākā tiesa, 2013b, 7. punkts).

Parasti ar likumu tiek noteikts, ka dalïba sociālās apdrošināšanas sistēmā, kas nozīmē arī pienākumu veikt sociālās apdrošināšanas iemaksas, ir obligāta (sk., piemēram: Saeima, 1997). Valsts tiesības uzlikt personām šādu pienākumu izriet no sociāli atbildīgas valsts principa un solidaritātes principa, jo, no vienas puses, cilvēkiem ir pienākums cits citam palīdzēt, bet, no otras puses, valstij ir pienākums nodrošināt aizsardzību sociāla riska gadījumā. Līdz ar to valsts, pildot savu pienākumu nodrošināt aizsardzību sociāla riska gadỉjumā, tiesību normās nostiprina cilvēku pienākumu savstarpēji palīdzēt un nosaka kārtību, kādā šis pienākums ir pildāms.

Pienākums nodrošināt aizsardzību sociāla riska gadījumā nozīmē, ka valstij ir jānodrošina sociālās nodrošinājuma sistēmas esība, adekvātums un pieejamība un tās radītajai sociālā nodrošinājuma sistēmai ir jābūt efektīvai, taisnīgai un ilgtspējigai. Sociālās nodrošinājuma sistēmas esība nozìmē, pirmkārt, to, ka šai sistēmai jāpastāv un turklāt jābūt ilgtspējigai, lai nodrošinātu, ka tiesības uz sociālo nodrošinājumu var istenot gan pašreizējās, gan arī nākamās paaudzes. Otrkārt, tas nozīmē, ka šai sistēmai jāaptver visi būtiskie gadījumi jeb riski. Par būtiskajiem gadijumiem jeb riskiem ir atzistami šādi deviṇi gadijjumi: 1) medicīniskā aprūpe, 2) ienākumu zaudējums slimības dēḷ, 3) vecums, 4) bezdarbs, 5) darba negadỉjumi un arodslimỉbas, 6) atbalsts ğimenēm un bērniem, 7) maternitāte, 8) invaliditāte, 9) apgādnieka zaudējums. Sociālās nodrošinājuma sistēmas adekvātums prasa, lai sociālais nodrošinājums būtu adekvātā apmērā un ilgumā. Sociālā nodrošinājuma sistēmai jābūt arī pieejamai. Ar pieejamību jāsaprot gan finansiālā pieejamỉba, gan fiziskā pieejamība, gan citu veidu pieejamība. Tas nozīmē, ka sociālā nodrošinājuma sistēmai jāaptver pietiekami plašs personu loks bez jebkādas diskriminācijas. Nosacỉjumiem sociālā nodrošinājuma iegūšanai ir jābūt pamatotiem, samērīgiem un caurskatāmiem (Kovaḷevska, 2011, 562.-566.lpp.).
Likumdevējam ir arī pienākums pakāpeniski pilnveidot sociālā nodrošinājuma sistēmu, tostarp palielinot sociālā nodrošinājuma apmēru. Taču iznēemuma gadijjumā valsts ir tiesīga samazināt sociālā nodrošinājuma līmeni (Kovalevska, 2011, 566.-567.lpp.). Par šādu iznēmuma gadijumu uzskatāma arī situācija, kad ir nepieciešams nodrošināt sociālās apdrošināšanas speciālā budžeta līdzsvarošanu, jo līdzsvarots budžets ir sociālā nodrošinājuma sistēmas ilgtspējas pamats (Satversmes tiesa, 2009a, 18.1. punkts). Lìdz ar to sociālā nodrošinājuma līmena samazināšanu šādā gadijjumā attaisno Latvijas Republikas Satversmes ievada 5. rindkopā minētais cilvēku pienākums izturēties atbildīgi pret citiem cilvēkiem un nākamajām paaudzēm. Tomēr pat straujas ekonomiskās lejupslīdes apstākḷos valstij saglabājas noteikts pamatpienākumu kopums, no kuriem tā nav tiesīga atkāpties. Ja valsts nav spējiga nodrošināt šo minimālo līmeni visām riska grupām, tai jānoteic, kuras sociālās grupas ir ipaši mazaizsargātas, un vismaz šīm grupām jāgarantē sociālais nodrošinājums (Kovaḷevska, 2011, 566.-568.lpp.).

SOCIĀLAIS TAISNĪGUMS Sociāli atbildiggas valsts principa elements ir arī valsts pienākums rūpēties par sociālo taisnīgumu, kas ietver rūpes par sociālo atšḳirību izlīdzināšanu, vājāko aizsardzību un iespēju vienlīdzību.

Sociảlo atšķiirību izlīdzināšana nozìmē materiālo un dạ̣ejii arī nemateriālo labumu pārdali no turīgākajiem par labu trūcīgākajiem, jo sociāli atbildỉga valsts atbalsta vājos, ierobežojot stipros (Levits, 2012, 39.lpp.; Pleps u.c., 2014, 150.lpp.). Šādas izlīdzinošas politikas istenošanas intensitāte ir valsts ziṇā, tomēr tas nepieḷauj labumu pārdali no trūcīgākajiem par labu turīgākajiem. Proti, nav pielaujams atnemt kādu valsts piedāvātu labumu trūcīgākajiem, lai turīgākajiem paliktu vairāk (Levits, 2012, 39. lpp.). Sociālo atšķirību izlīdzināšana parasti tiek îstenota ar valsts nodokḷu sistēmas starpniecỉbu. Kā norādijjusi Satversmes tiesa, «nodokla pamatfunkcija ir fiskālā funkcija, kas nodrošina ieṇēmumus valsts budžetā un pašvaldību budžetos. Ar šo ieṇēmumu palīdzību ir iespējams finansēt prioritārus sociālos un ekonomiskos pasākumus, kā arī mazināt personu ienākumu un labklājības līmeṇa nevienlīdzību. Tādējādi valsts nodokḷu politiku izmanto arī sociālās politikas mērķu sasniegšanai» (Satversmes tiesa, 2007c, 23. punkts). Valsts pienākum izlīdzināt sociālās atšḳirības ir pamatojums tam, kāpēc par tiesiskās vienlïdzības principam atbilstošu var atzīt progresīvo ienākuma nodokḷa likmi (Grigore-Bāra u.c., 2014, 219.lpp.).

Valsts pienākumu izlīdzināt sociālās atškiirības Satversmes tiesa uzsvēra vienā no lietām par bērna kopšanas pabalstu. 2006. gada 2. novembra spriedumā lietā Nr. 2006-07-01 Satversmes tiesa norādijja: «Tādējādi ğimenes, kurās materiālu apstākḷu dēḷ persona, kas kopj bērnu, var ațlauties nestrādāt, sanem lielāku valsts atbalstu, savukārt trūcīgākās ğimenes ir spiestas sanem bērna kopšanas pabalstu ierobežotā apmērā. Šāds Satversmes 110. pantā 
paredzēto tiesību konkretizējums ir pretrunā ar sociāli atbildīgas valsts principu, kas liek valstij iespēju robežās gādāt par sociālo atšķirību izlīdzināšanu, tas ir, gādāt, lai saprātiga valsts palìdzība tiktu sniegta visiem bērniem, kam tā nepieciešama.» (Satversmes tiesa, 2006b, 18.2. punkts) Tā kā apstrīdētās normas rezultātā veidojās situācija, ka turīgākās ğimenes saṇem lielāku atbalstu no valsts, bet trūcīgākās ớimenes mazāku atbalstu, tad Satversmes tiesa atzina, ka norma neatbilst Satversmei (Grigore-Bāra u.c., 2014, 219.lpp.).

Valstij no sociāli atbildīgas valsts principa izriet arī pienākums rūpēties par vājāko aizsardzību. Satversmes tiesa ir norādījusi, ka, piemēram, ekonomiskās krīzes situācijā slogs, kas gulstas uz sabiedrỉbas locekḷiem, ir jāsadala, gan ievērojot sabiedrības loceklu solidaritāti, gan arī nemot vērā nepieciešamību aizsargāt vājākos sabiedrības locekḷus (Satversmes tiesa, 2011c, 19.3. punkts). Valsts, rūpējoties par vājāko aizsardzỉbu, var pakḷaut stingrai regulācijai arī tādas jomas, kas pieder pie privāttiesībām, ja šajās jomās tiesisko attiecību dalībnieki faktiski nav vienlīdzīgi. Šādos gadījumos tiek ierobežota līgumu brīvibas principa darbỉba (Schmidt-Bleibtreu \& Klein, 1995, S. 512). Satversmes tiesa 2005. gada 17. janvāra spriedumā lietā Nr. 2004-10-01 atzina, ka darba tiesības ir nozare, kurā tiek uzskatits, ka viena no līguma pusēm - darbinieks - atrodas ekonomiskajā ziṇā vājākā pozīcijā. Satversmes tiesa šajā lietā uzskatīja, ka līdzīgi apsvērumi attiecas arī uz patērētājiem. Turklāt spriedumā norādīts, ka Patērētāju tiesību aizsardzības likuma nodrošinātā patērētāju aizsardzība ir plašāka, nekā dažkārt tiek uzskatīts, jo arī, piemēram, patērētāju kreditēšanas (līzinga) un lielākoties īres līgumi esot uzskatāmi par patērētāju līgumiem. Savukārt konkurences tiesību normas nodrošina aizsardzību gadỉjumā, kad viena vai vairāku tirgus dalībnieku ekonomiskais stāvoklis ḷautu uzspiest tādus līguma noteikumus, kuriem citos apstākḷos pārējie darijumu dalībnieki nepiekristu (Satversmes tiesa, 2005a, 9.3. punkts).

Tātad Satversmes tiesa ir atzinusi, ka darba tiesības, patērētāju tiesības, kas vismaz daḷēji attiecināmas arī uz dzīvojamo telpu īres tiesībām, un konkurences tiesības ir tās jomas, kur valstij jānodrošina vājāko aizsardzība. Arī citos spriedumos Satversmes tiesa atzinusi, ka darba ṇēmēji ir sociāli vājākas personas, kam nepieciešama īpaša sociāla aizsardzība (Satversmes tiesa 2001; Satversmes tiesa, 2015b, 16. punkts), un ka patērētājs ir ekonomiski nesalīdzināmi vājāks līdzējs nekā kredīta devējs, kuram būtu neierobežotas iespējas diktēt līguma noteikumus, ja nebūtu spēkā patērētāju aizsardzības tiesību normās noteiktie ierobežojumi (Satversmes tiesa, 2011a, 19. punkts).

Satversmes tiesa ir norādijjusi, ka ari teritorijas plānojuma izstrādāšanas procedūra ir saistīta ar vājāko personu aizsardzību. Proti, teritorijas plānojuma izstrādāšanas procedūra ir reglamentēta, lai varētu identificēt un izsvērt dažādas intereses un noteikt, kurām no tām plānojumā dodama prioritāte. Šajā procesā jāpanāk visu iesaistìto pušu interešu līdzsvarošana, vājāko dalībnieku aizsardzība un valdības pārstāvēto visas sabiedrības interešu nodrošināšana (Satversmes tiesa, 2004a, 5.1. punkts).

Vienlaikus Satversmes tiesa, atsaucoties uz Polijas Konstitucionālo tribunālu, ir atzinusi, ka valsts, rūpējoties par vājāko personu aizsardzību, nevar visu atbildības nastu uzvelt vienai sabiedrības grupai. Konkrētajā lietā tika norādìts, ka valstij jānodrošina taisniggs līdzsvars starp izīrētāju un îrnieku interesēm, taču iedzīvotāju finansiālo grūtību novelšana tikai uz īpašnieku pleciem nav uzskatāma par taisnīgu. Ja valsts sociālo atbalstu uzskata par vajadzīgu, tam saskaṇā ar pareizu sociālās solidaritātes principa izpratni jātiek sniegtam no visas sabiedrïbas, t.i., valsts lïdzekliem (Satversmes tiesa, 2006a, 15.8. punkts). Satversmes tiesa ir arī atzinusi, ka nepieciešamība aizsargāt darbinieku kā vājāko personu tomēr nevar sniegties tik tālu, ka darba devējam tiek liegtas tiesības sprieduma izpildišanas pagrieziena rezultātā atgūt ar nekavējoties izpildìtu spriedumu bez tiesiska pamata piedzìtos naudas līdzekḷus. Konkrētajā lietā par Latvijas Republikas Satversmei neatbilstošu tika atzìta norma, kas paredzēja, ka darbinieks, ja vien viņš tiesai nav sniedzis nepatiesas ziņas vai iesniedzis viltotus dokumentus, var neatmaksāt no darba devēja vinam par labu ar nekavējoties izpildītu tiesas spriedumu piedzìtos nepieciešamos iztikas līdzekḷus. Satversmes tiesa norādijja, ka vājākās personas aizsardzība tiesas procesā tiek paredzēta, lai panāktu taisnīgu tiesvedības procesa rezultātu, taču apstrīdētā norma to nenodrošina (Satversmes tiesa, 2011a, 19. punkts).

Sociālais taisnīgums prasa valstij rūpēties arī par iespēju vienlīdzības nodrošināšanu. Tas nozīmē, ka valstij jārūpējas, lai faktiski visiem tiktu radīti vienlīdzịgi apstākli materiālu un nemateriālu labumu iegūšanai. Tātad valstij nevis jānodrošina ikvienam šie materiālie vai nemateriālie labumi vienādā daudzumā, bet gan jānodrošina vienlīdzịgas iespējas tos iegūt. Iespēju vienlïdzības nodrošināšanas kontekstā ìpaši nozìmīgi ir nodrošināt vienlīdzīgas iespējas iegūt izglìtỉbu un vienlīdzīgas tiesības izvēlēties nodarbošanos. Izglìtība un darbs lielā mērā ir pamats tam, lai varētu runāt par vienlīdzīgām iespējām iegūt pārējos labumus (Kovalevska, 2008).

Satversmes tiesa iespēju vienlīdzības kontekstā ir izteikusies tikai par augstāko izglīīibu, atzīstot: principā ir pieḷaujams noteikt, ka stipendijas tiek piešķirtas tikai sociāli mazaizsargātiem augstskolu studentiem. Satversmes tiesa, atsaucoties uz Eiropas Komisiju, norādijja, ka studentu atbalsta pasākumi ir nepietiekami, lai nodrošinātu vienādas iespējas gūt panākumus studentiem, kuru sociālā un materiālā situācija tiek uzskatīta par salīdzinoši sliktāku. Izcilību mācībās un pētniecībā var būt grūti sasniegt, ja dalai personu sociālekonomisku faktoru dēḷ pieeja studijām vai ar pētniecību saistitai karjerai ir ierobežota (Satversmes tiesa, 2011b, 13.5. punkts).

lespēju vienlïdzības nodrošināšanas kontekstā nozīmịgs ir arī Latvijas Republikas Satversmes 91. pants, jo tiesiskās vienlīdzỉbas princips ir viens 
no sociāli atbildīgas valsts principa îstenošanas instrumentiem (Levits, 2011, 76.lpp.). Pirmkārt, būtiska nozīme ir šajā pantā nostiprinātajam diskriminācijas aizliegumam. Piemēram, Konvencija par personu ar invaliditāti tiesībām paredz dalībvalstu pienākumu sekmēt universālā dizaina ${ }^{8}$ izmantošanu un pieejamību ēkām, ceḷiem, transportam, informācijas, sakaru un citiem pakalpojumiem, tādējādi veicinot to, lai visas personas ar invaliditāti varētu pilnībā îstenot visas cilvēktiesības un pamatbrīvỉbas bez jebkāda veida diskriminācijas invaliditātes dēl (ANO, 2010, 4. panta pirmās daḷas «f» punkts un 12. pants). ${ }^{9}$ Universālais dizains un pieejamības nodrošināšana ir tādi pasākumi, no kuriem labumu gūst noteiktas sabiedrības grupas. Taču konvencija paredz arī to, ka var būt nepieciešams veikt pasākumus, kas attiecas uz konkrētu indivìd un vina iespējām vienlīdzịgi îstenot cilvēktiesības (Committee on the Rights of Persons with Disabilities, 2014, para. 25). Proti, atbilstoši šis konvencijas 5. panta trešajai dalaia, lai veicinātu vienlïdzību un likvidētu diskrimināciju, dalībvalstis veic visus atbilstošos pasākumus, lai nodrošinātu, ka tiek veikti saprātīgi pielāgojumi. Saprātīgs pielāgojums nozìmē vajadzịgās un atbilstošās izmainas un korekcijas - ja tās konkrētā gadỉjumā ir nepieciešamas un neuzliek nesamērīgu vai nepamatotu slogu -, lai nodrošinātu, ka personas ar invaliditāti vienlīdzīgi ar citiem var izmantot vai istenot visas cilvēktiesības un pamatbrīivibas. Saprātīgs pielāgojums var ietvert tādus pasākumus kā lifta vai uzbrauktuves ierikkošana un tualetes pielāgošana personām ratinkrēeslā. Tas var nozīmēt arī to, ka personai ar redzes traucējumiem var būt nepieciešams piešķirt ilgāku laiku pārbaudījuma kārtošanai (Eiropas diskriminācijas novēršanas, 2011, 36.-37.lpp.). Savukārt personu ar garīgu atpalicību gadỉjumā saprātīgs pielāgojums var izpausties tā, ka var būt nepieciešams dot šìm personām ilgāku laiku nekā citiem, lai tās iesniegtu tādus apdrošināšanas stāžu pierādošus dokumentus, kas nepieciešami vecuma pensijas pieškiršanai un aprēkināšanai (Administratīiā apgabaltiesa, 2013c, 14. punkts).

Otrkārt, iespēju vienlīdzību var saistìt arī ar prasību, kas izriet no Latvijas Republikas Satversmes 91. panta, proti, nodrošināt ne tikai vienādu attieksmi pret personām, kas atrodas vienādos apstāklos, bet arī atškirìgu attieksmi pret personām, kas atrodas atšḳirīgos apstākḷos. Konkrēts šīs prasības pārkāpums tika konstatēts Satversmes tiesas 2007. gada 21. janvāra spriedumā lietā Nr. 2006-08-01: «Apstrīdētajā normā ietvertā ierobežojuma piemērošanas gadījumā kopējais pabalstu apmērs kḷūst vienāds gan bērniem invalīdiem ar mēreni izteiktiem organisma sistēmu funkciju traucējumiem, gan bērniem invalīdiem ar smagiem fiziskiem un funkcionāliem traucējumiem. Lìdz ar to netiek sasniegts mērkis nodrošināt papildu atbalstu bērniem invalīiem ar smagiem fiziskiem un funkcionāliem traucējumiem un atškiirīgām personu grupām netiek nodrošināta atškirīga attieksme.» Tādējādi šajā lietā faktiski ir atzīts, ka dažādām personu grupām netiek nodrošināta iespēju vienlïdzība. Tā kā šo ǵ̛imenu faktiskais stāvoklis atškiras, tad, nodrošinot vienādu palīdzību no valsts, netiek nodrošinātas vienlīdzīgas iespējas šīm ớimenēm goū dzivei nepieciešamos labumus (Grigore-Bāra u.c., 2014, 221.lpp.).

Satversmes tiesa ir atzinusi valsts pienākumu nodrošināt iespēju vienlīdzību arī tajos gadỉjumos, kad tā runā par valsts pienākumu ne tikai garantēt tiesības formāli, bet arī nodrošināt efektīvu to ìstenošanu praksē. Piemēram, Satversmes tiesa 2008. gada 9. maija spriedumā lietā Nr. 2007-24-01 norādīja, ka valstij ir pienākums maksāt par ieslodzìto personu saraksti, kas saistìta ar pieeju tiesai, gadijjumos, kad personas rīcībā nav finanšu lỉdzeklu sarakstes izdevumu segšanai (Satversmes tiesa, 2008b, 12. punkts). Tādējād šajā lietā Satversmes tiesa atzina, ka valstij ir pienākums nodrošināt vienlìdzīgas iespējas attiecībā uz pieeju tiesai, lai tās nebūtu atkarīgas tikai no personu finansiālā stāvokḷa. Līdz ar to no sociāli atbildīgas valsts principa un pienākuma nodrošināt iespēju vienlīdzību izriet arī valsts pienākums paredzēt iespēju samazināt valsts nodevu vai drošìbas naudu, kas jāmaksā par dažādu dokumentu iesniegšanu tiesā, kā arī citus tiesāšanās izdevumus (Schmidt-Bleibtreu \& Klein, 1995, S. 511). Satversmes tiesa, piemēram, konstatēja tiesību uz taisnīgu tiesu pārkāpumu gadỉjumā, kad tiesību normas neparedzēja iespēju samazināt maksātnespējas procesa depozìta iemaksu darbiniekiem, kuru vienīgais tiesību aizsardzības līdzeklis ir darba devēja pasludināšana par maksātnespējigu (Satversmes tiesa, 2012b).

CILVĒKA PIENĀKUMI PRET SABIEDRĪBU Sociāli atbildīgas valsts princips nozīmē arì to, ka indivìds ir saistīts ar sabiedrību un līdz ar to tam ir arī pienākumi pret sabiedrību. Tāpēc indivìdam jāsamierinās ar vina rīcības brīvibas ierobežojumiem, kas tiek noteikti, lai veicinātu sociālo kopdzivi (Vildbergs u.c., 2004, 121.lpp.).

Šì ideja ir cieši saistīta ar solidaritātes principu, un tā ir atspoguḷota arī Latvijas Republikas Satversmes ievada 5.rindkopā ietvertajā ikvienas personas pienākumā rūpēties par sabiedrības kopējo labumu un arī pienākumā izturēties atbildīgi pret nākamajām paaudzēm. Šis sociāli atbildīgas valsts principa elements ir konkretizēts arī Latvijas Republikas Satversmes 116. pantā, kurš paredz, ka leğitīms mērḳis pamattiesību ierobežošanai ir sabiedrības labklājība. Kā norāda Egils Levits, sabiedrības labklājība «aptver vispirms sabiedrības kopējās materiālās labklājības aspektus. Tādēl te pieder dažādi pasākumi, kas vērsti uz sabiedrības kopējo materiālo labumu palielināšanu vai pārdalī̌̌anu starp sabiedrỉbas locekḷiem. To vidū centrāla loma ir nodoklu un sociālajai likumdošanai, kas tādējādi var leớitīmi ierobežot, piemēram, Satversmes 105. pantā garantētās individa īpašumtiesỉbas. 
Taču jēdziens «sabiedrības labklājiba» aptver arī nemateriālus aspektus, kas nepieciešami pēc iespējas harmoniskākai sabiedrības funkcionēšanai. Šeit pieder, piemēram, pienākums sūtīt bērnus skolā, kas ierobežo Satversmes 110. pantā garantētās vecāku tiesības» (Levits, 2000, 286.-287. lpp.).

Satversmes tiesa ir atzinusi, ka ieṇēmumi no nodokḷiem veido būtisku un neatṇemamu kopējo valsts budžeta ieṇēmumu dalı, nodrošinot valsts spēju pildīt savas funkcijas, arī savus pienākumus pamattiesỉbu nodrošināšanas jomā. Ar šo ieneèmumu palīdzību ir iespējams finansēt prioritārus sociālos un ekonomiskos pasākumus, kā arī mazināt personu ienākumu un labklājỉbas līmeṇa nevienlīdzỉbu. Lìdz ar to personas tiesību uz īpašumu ierobežošana, paplašinot ar nodokli apliekamo objektu loku (piemēram, uzsākot no kapitāla pieauguma gūtos ienākumus aplikt ar iedzìvotāju ienākuma nodokli), kalpo sabiedrïbas labklājibas nodrošināšanai (Satversmes tiesa, 2010d, 9. punkts). Tā kā valstij ir pienākums sabiedrības labklājības interesēs izveidot efektīvu nodokḷu iekasēšanas sistēmu, tad arī tiesību normas, kas paredz atbildỉbu par nodokḷu likumu pārkāpšanu vai priekšnoteikumus atbrīvošanai no šādas atbildības, ir noteiktas sabiedrības labklājības interesēs (Satversmes tiesa, 2008a, 7. un 15. punkts). Sabiedrības labklājība tiek veicināta arī ar normu, kas paredz izslēgt no turpmākas dalības publiskā iepirkuma procedūrā pretendentus, kuri pilnībā nepilda nodokḷu maksāšanas saistības, jo tā stimulē uzṇēmējus maksāt nodokḷus un tādējādi sekmē pilnvērtīgu nodokḷu iekasēšanu (Satversmes tiesa, 2011d, 19. punkts).

Satversmes tiesa vairākos spriedumos ir izmantojusi šo sociāli atbildỉgas valsts principa elementu, lai izvērtētu un arī attaisnotu noteiktos ierobežojumus personas tiesībām uz sociālo nodrošinājumu. Satversmes tiesa šajās lietās ir norādījusi, ka valstij jāsamēro ar savām ekonomiskajām iespējām ne tikai personas tiesības sociālajā jomā, bet arī nepieciešamība nodrošināt visas sabiedrības labklājību un jārada tāds tiesiskais regulējums, kas būtu vērsts uz valsts ilgtspējigu attīstỉbu. Ekonomiskās lejupslīdes apstākḷos, izvērtējot apstrīdētās normas atbilstỉbu Satversmei un vispārējiem tiesību principiem, par kritēriju noder tas, vai likumdevēja izraudzìtais risinājums ir sociāli atbildīgs. Sociāli atbildīgs risinājums ir tāds risinājums, kura rezultātā atsevišķu personu tiesiskās intereses tiek saskaṇotas ar visas sabiedrības interesēm (Satversmes tiesa, 2010b, 22. punkts; Satversmes tiesa, 2011e, 24. punkts; Satversmes tiesa, 2012a, 11. punkts). Ekonomiskās krīzes situācijā slogs, kas gulstas uz sabiedrības locekḷiem, jāsadala, ievērojot sabiedrības locekḷu solidaritāti. Sociālā solidaritāte ekonomiskās krīzes apstākḷos nozīmē to, ka ikviens pilsonis uznemas proporcionālu atbildību par smago krīzes seku novēršanu (Satversmes tiesa, 2010a, 10.3. punkts; Satversmes tiesa, 2011c, 19.3. punkts). Tādējādi Satversmes tiesa ir norādỉjusi, ka personai jābūt gatavai arī paciest zināmus ierobežojumus, ja tas ir nepieciešams sabiedrības labklājības nodrošināšanai (Grigore-Bāra u. c., 2014, 223.lpp.).
Tas, ka individam var būt pienākumi pret sabiedrību, izriet arī no citiem Satversmes tiesas spriedumiem. Kā piemēru var minēt Satversmes tiesas spriedumu par valsts tiesībām noteikt kriminālatbildību par narkotiku lietošanu. Šajā spriedumā Satversmes tiesa norādỉja, ka tiesības uz privāto dzivi var ierobežot arī tad, ja indivìda rīcība ir vērsta pret pašas personas veselību, par ko sabiedrība jūt atbildību. Spriedumā uzsvērts, ka indivīda veselībai ir ne tikai personiska, bet arī sociāla vērtība (Satversmes tiesa, 2005b, 11. un 14.1. punkts). Satversmes tiesa ir arī atzinusi, ka sabiedrỉbas labklājības interesēs ir pieḷaujams ierobežot tiesības streikot. Šajā lietā apstrīiētā tiesību norma paredzēja, ka streiku nedrīkst uzsākt, kamēr tiesa nav izskatījusi pieteikumu par šā streika atzišanu par nelikumīgu. Satversmes tiesa secināja, ka streika dēl tiek kavēta ražošana un uzṇēmuma darbs, un tā rezultātā darba devējam rodas zaudējumi. Turklāt streiks var negatīvi skart nestreikojošos un citas trešās personas, kā arī sabiedrỉbu. Lìdz ar to streika gadijumā var tikt nodarìts kaitējums arī sabiedrības ekonomiskajai labklājībai. Tāpēc apstrīdētās normas mērḳis ir ne tikai darba devēja interešu un tiesỉbu aizsardzība, bet arī sabiedrïbas labklājības aizsardzība (Satversmes tiesa, 2007b, 10. punkts). Tāpat Satversmes tiesa ir atzinusi, ka sabiedrỉbas labklājības aizsardzībai kalpo tiesību normās noteiktais pienākums maksāt dabas resursu nodokli par ūdens kā sabiedrībai svarīga resursa izmantošanu saimnieciskajā darbỉbā, jo ūdenim kā resursam ir neatsverama nozīme ilgtspējiggas attīstības nodrošināšanā (Satversmes tiesa, 2015a, 19. punkts). Savukārt likumdevēja dotais pilnvarojums Ministru kabinetam uz noteiktu laiku apturēt tiesību piešķiršanu ražotājiem kvalificēties saražotās elektroenerǵijas pārdošanai obligātā iepirkuma ietvaros aizsargā sabiedrības labklājỉbu, nepielaujot nesamērīgu elektroenerǵijias kopējās cenas pieaugumu (Satversmes tiesa, 2015c, 14. punkts).

Tipisks piemērs ir arī Satversmes tiesas 2007. gada 26. aprịla spriedums lietā Nr. 2006-38-03 par tiesỉbu uz ỉpašumu ierobežojumiem, kas tika noteikti ar Limbažu pilsētas teritorijas plānojumu. Satversmes tiesa norādīja, ka īpašums modernajās civiltiesībās tiek uzskatīts ne tikai par individuālu kategoriju, bet arī par sociālu vērtību. Sociālā funkcija uzliek katram īpašniekam par pienākumu rēķināties ar citu interesēm. Īpašuma tiesības diezgan bieži tiek ierobežotas vispārības labā, kaimiṇu interesēs, kas atṇem tām antisociālo raksturu. Satversmes 105. pantā šo ideju izteic otrais teikums -ipašumu nedrīkst izmantot pretēji sabiedrības interesēm (Satversmes tiesa, 2007a, 10. punkts). Tātad īpašuma sociālās funkcijas mērḳis ir panākt taisnīgu līdzsvaru starp sabiedrības interesēm un indivīda pamattiesībām (Satversmes tiesa, 2014, 20. punkts). Tāpat Satversmes tiesa ir atzinusi, ka iespējami arī tādi gadījumi, kad valstij, atsavinot personai piederošo ippašumu nolūkā panākt lielāku sociālo taisnigumu, nav pienākuma maksāt pilnu īpašuma tirgus cenu, piemēram, ippašuma reformas apstākḷos (Satversmes tiesa, 2005c, 22.3. punkts). 


\section{Kopsavilkums}

Sociāli atbildīgas valsts virsprincips ir viens no principiem, kas raksturo konstitucionālas demokrātijas valsts iekārtu Eiropā. Sociāli atbildīgas valsts idejas pirmsākumi meklējami 19. gadsimtā un ir saistìti ar industrializācijas un kapitālisma izraisītajām sociālajām, ekonomiskajām un politiskajām pārmaiñām. Šìs idejas pamatlicējs ir vācu ekonomists un jurists Lorencs fon Šteins, kurš jau 19. gadsimtā pamatoja, kāpēc nepieciešama valsts iejaukšanās sabiedrības sociālajos un ekonomiskajos apstāklos, un izmantoja terminu «sociāla valsts». 19. gadsimtā valstis sāka realizēt arī sociāli atbildīgas valsts ideju, pieņemot likumus gan darba aizsardzības jomā, gan arī sociālās drošỉbas jomā. 1949. gadā Vācija bija pirmā, kura savā konstitūcijā tieši noteica, ka tā ir sociāla valsts. Mūsdienās sociāli atbildīgas valsts princips konstitūcijās var būt nostiprināts divos veidos. Pirmkārt, ir valstis, kuru konstitūcijās, lietojot dažādus formulējumus, ir tieši noteikts, ka tās ir sociāli atbildīgas valstis. Otrkārt, ir valstis, kuru konstitūcijās nav tieši noteikts, ka tās ir sociāli atbildỉgas, tomēr šāds secinājums izriet no cita konstitūcijā ietvertā regulējuma.

Latvijas Republikā pirmajā neatkarības posmā konstitūcijās nebija tieši noteikts, ka Latvija ir sociāli atbildīga valsts, un tas neizrietēja arì no konstitūcijās ietvertā regulējuma. Tomēr Latvijas Republika isstenoja sociāli atbildīgas valsts idejai atbilstošu politiku. Posmu pēc neatkarības atjaunošanas var iedalīt trīs dạ̣ās -1) no neatkarības atjaunošanas līdz 1998. gada 5. novembrim, 2) no 1998. gada 6. novembra līdz 2014. gada 21. jūlijam, 3) no 2014. gada 22. jūlija līdz šim brīdim. Pirmajā posmā Latvijas Republika turpināja realizēt sociāli atbildīgas valsts idejai atbilstošu politiku, un ir pamats uzskatît, ka Latvijas Republikai jau šajā posmā bija konstitucionāls pienākums isstenot sociāli atbildīgas valsts idejai atbilstošu politiku. Otro posmu ievadija grozijumu izdarišana Latvijas Republikas Satversmē, papildinot to ar VIII nodalu «Cilvēka pamattiesibas». Lìdz ar to no 1998. gada 6. novembra Latvijas Republika nepārprotami piederēja pie to valstu loka, kurās sociāli atbildīgas valsts principam bija konstitucionāls rangs. Nozīmīgs notikums bija arī tas, ka Satversmes tiesa pirmo reizi tieši savā spriedumā norādīja, ka Latvija ir sociāli atbildīga valsts. Trešo posmu ievadỉja vēl vienu grozijjumu izdarī̌šna Latvijas Republikas Satversmē, izvēršot tās ievadu. Ievada 4. rindkopā ir noteikts, ka Latvija ir sociāli atbildīga valsts. Lìdz ar to no 2014.gada 22.jūlija Latvija pieder pie to valstu loka, kuru konstitūcijā ir tieši noteikts, ka attiecīgā valsts ir sociāli atbildīga valsts.

Latvijas Republikā sociāli atbildīgas valsts princips ietver sevī šādus četrus elementus: 1) valsts pienākumu nodrošināt cilvēka cienigas eksistences minimālos priekšnoteikumus, kas ietver sociālās palīdzības sniegšanu, pamatpakalpojumu nodrošināšanu, kā arì izglìtības, veselības un sociālās aprūpes, kultūras iestāžu pieejamības nodrošināšanu; 2) valsts pienākumu nodrošināt aizsardzību sociāla riska gadījumā, kas nozīmē, ka valstij ir jānodrošina sociālās nodrošinājuma sistēmas esamība, adekvātums un pieejamība un tās radītajai sociālā nodrošinājuma sistēmai ir jābūt efektīvai, taisnīgai un ilgtspējiggai; 3) valsts pienākumu rūpēties par sociālo taisnīgumu, kas ietver rūpes par sociālo atškiirību izlīdzināšanu, vājāko aizsardzību un iespēju vienlīdzību; 4) cilvēka saistību ar sabiedrību. Tas uzliek pienākumu visiem trīs valsts varas atzariem. Primārā atbildība par šā principa realizāciju ir likumdevējam, kam normatīvajos aktos jākonkretizē sociāli atbildīgas valsts princips. Savukārt izpildvarai un tiesu varai šis princips jāizmanto tiesību normu interpretācijā un piemērošanā.

\section{Izmantotie avoti}

Administratīvā apgabaltiesa (2012). 10.09.2012. spriedums lietā Nr.A421016109. Izgūts no https://manas.tiesas.lv/eTiesasMvc/nolemumi

Administratīīā apgabaltiesa (2013a). 26.03.2013. spriedums lietā Nr. A420460211. Izgūts no https://manas.tiesas.lv/eTiesasMvc/nolemumi

Administratīvā apgabaltiesa (2013b). 31.05.2013. spriedums lietā Nr.A420653311. Izgūts no https://manas.tiesas.lv/eTiesasMvc/nolemumi

Administratīvā apgabaltiesa (2013c). 27.09.2013. spriedums lietā Nr.A420528911. Izgūts no https://manas.tiesas.lv/eTiesasMvc/nolemumi

Administratīiā apgabaltiesa (2013d). 28.11.2013. spriedums lietā Nr. A420615810. Izgūts no https://manas.tiesas.lv/eTiesasMvc/nolemumi

Administratīiā rajona tiesa (2012). 28.04.2012. spriedums lietā Nr. A421016109. Izgūts no https://manas.tiesas.lv/eTiesasMvc/nolemumi

ANO (2010, 17. febr.). Konvencija par personu ar invaliditāti tiesībām: starptautisks ligums. Latvijas Vēstnesis, 27.

Augstākā Padome (1990a, 17. maijs). Par Latvijas Republikas neatkarības atjaunošanu: Latvijas Republikas Augstākās Padomes deklarācija. Latvijas Republikas Auğstākās Padomes un Valdības Ziṇotājs, 20.

Augstākā Padome (199ob, 24. maijs). Par Latvijas Republikas pievienošanos starptautisko tiesību dokumentiem cilvēktiesỉbu jautājumos: Latvijas Republikas Augstākās Padomes deklarācija. Latvijas Republikas Auğstākās Padomes un Valdības Ziñotājs, 21.

Augostākā Padome (1992, 30.janv.). Konstitucionālais likums «Cilvēka un pilsona tiesības un pienākumi»: Latvijas Republikas likums. Latvijas Republikas Auğstākāa Padomes un Valdības Ziṇotājs, 4.

Augstākā tiesa (2008). 12.05.2008. spriedums lietā Nr. SKA-247/2008. Izgūts no https://manas.tiesas.lv/eTiesasMvc/nolemumi

Augstākā tiesa (2010a). 08.07.2010. lēmums lietā Nr. SKA-635/2010. Izgūts no http:// at.gov.lv/lv/judikatura/judikaturas-nolemumu-arhivs/senata-administrativolietu-departaments/hronologiska-seciba/2010-hronologiska-seciba/ 
Augstākā tiesa (2010b). 16.09.2010. lēmums lietā Nr. SKA-548/2010.

Augstākā tiesa (2011a). 25.03.2011. spriedums lietā Nr. SKA-75/2011. Izgūts no https:// manas.tiesas.lv/eTiesasMvc/nolemumi

Augstākā tiesa (2011b) 20.05.2011. spriedums lietā Nr. SKA-102/2011. Izgūts no https://manas.tiesas.lv/eTiesasMvc/nolemumi

Augstākā tiesa (2013a). 09.07.2013. spriedums lietā Nr. SKA-334/2013. Izgūts no https://manas.tiesas.lv/eTiesasMvc/nolemumi

Augstākā tiesa (2013b). 23.10.2013. spriedums lietā Nr. SKA-492/2013. Izgūts no https://manas.tiesas.lv/eTiesasMvc/nolemumi

Campanelli, D. (b.g.). Principle of Solidarity. In Max Planck Encyclopedia of Public International Law. Retrieved from http://opil.ouplaw.com/view/10.1093/ law:epil/9780199231690/law-9780199231690-e2072?rskey=402wYD\& result $=1 \&$ prd $=$ EPIL

Castles, F. G., Leibfried, S., Lewis, J., Obinger, H., \& Pierson, C. (Eds.) (2010). The Oxford Handbook of the Welfare State. Oxford: Oxford University Press.

Committee on Economic, Social and Cultural Rights. General Comment No.13 (1999). The right to education (article 13 of the Covenant). Retrieved from http://tbinternet.ohchr.org/_layouts/treatybodyexternal/TBSearch.aspx? Lang $=$ en\& TreatyID $=9 \&$ DocTypeID $=11$

Committee on Economic, Social and Cultural Rights. General Comment No. 14 (2000). The right to the highest attainable standard of health (article 12 of the International Covenant on Economic, Social and Cultural Rights). Retrieved from http://tbinternet.ohchr.org/_layouts/treatybodyexternal/TBSearch.as px?Lang $=$ en $\&$ TreatyID $=9 \&$ DocTypeID $=11$

Committee on Economic, Social and Cultural Rights. General comment No. 21 (2009). Right of everyone to take part in cultural life (art.15, para.1 (a), of the International Covenant on Economic, Social and Cultural Rights). Retrieved from http://tbinternet.ohchr.org/_layouts/treatybodyexternal/TBSearch.as px? Lang $=$ en\& TreatyID $=9 \&$ Doc TypeID $=11$

Committee on the Rights of Persons with Disabilities. General comment No. 2 (2014). Article 9: Accessibility. Retrieved from http://daccess-dds-ny.un.org/ doc/UNDOC/GEN/G14/o33/13/PDF/G1403313.pdf?OpenElement

Constitutent Assambley (1947). The Constitution of the Italian Republic. Retrieved from http://www.senato.it/documenti/repository/istituzione/costituzione_ inglese.pdf

The Constitution of France (1958). Retrieved from http://www.assemblee-nationale. $\mathrm{fr} /$ english/index.asp

The Constitution of Spain (1978). Retrieved from http://www.congreso.es/portal/ page/portal/Congreso/Congreso/Hist_Normas/Norm/const_espa_texto_ ingles_o.pdf

The Constitution of the Republic of Estonia (1992). Retrieved from https://www. riigiteataja.ee/en/eli/530102013003/consolide
The Constitution of the Republic of Lithuania (1992). Retrieved from http://www3. Irs.lt/home/Konstitucija/Constitution.htm

The Constitution of the Republic of Poland (1997). Retrieved from http://www.sejm. gov.pl/prawo/konst/angielski/kon1.htm

The Constitution of the Russian Federation (1993). Retrieved from http://www. constitution.ru/en/10003000-01.htm

Constitutional Court of the Republic of Lithuania (2004). Ruling, case No.44/01, 05.03.2004. Retrieved from http://www.lrkt.lt/en/court-acts/search/170/ ta126o/content

Constitutional Court of the Republic of Lithuania (2012). Ruling, case No.46/2010-47/2010-48/2010-49/2010-51/2010-52/2010-70/2010-77/201082/2010-83/2010-84/2010-85/2010-86/2010-87/2010-94/2010-100/2010101/2010-109/2010-114/2010-123/2010-124/2010-128/2010-129/2010-133/2010134/2010-142/2010-143/2010-1/2011-2/2011-5/2011-8/2011-16/2011-21/201123/2011-25/2011-29/2011-32/2011-37/2011-39/2011, 06.02.2012. Retrieved from http://www.lrkt.lt/en/court-acts/search/170/ta1073/content

Constitutional Review Chamber of the Supreme Court (2004). Judgment case No. 3-4-1-7-03, 21.04.2004. Retrieved from http://www.nc.ee/?id=412

Council of Europe (1961). European Social Charter. Retrieved from http://www.coe. int/en/web/conventions/search-on-treaties/-/conventions/treaty/o35

Council of Europe (1996). European Social Charter (revised). Retrieved from http:// www.coe.int/en/web/conventions/search-on-treaties/-/conventions/treaty/163

Dišlers, K. (2004). Latvijas valsts varas orgāni un vin,u funkcijas. Rīga: Tiesu namu ağentūra.

Eiropas diskriminācijas novēršanas tiesību rokasgrgāmata (2011). Luksemburga: Eiropas Savienības Publikāciju birojs.

Grigore-Bāra, E., Kovaḷevska, A., Liepa, L., Levits, E., Mits, M., Rezevska, D., ... Sniedzite, G. (2014). 1. pants. No Latvijas Republikas Satversmes komentāri. Ievads. I nodaḷ. Vispārējie noteikumi. Autoru kolektīvs R. Baloža zinātniskā vadībā. Rīga: Latvijas Vēstnesis.

Heinig, H. M. (2008). Der Sozialstaat im Dienst der Freiheit. Zur Formel vom «sozialen» Staat in Art. 20 Abs. 1 GG. Tübingen: Mohr Siebeck.

Hufen, F. (2007). Staatsrecht II. Grundrechte. München: Verlag C. H. Beck.

Ideju vārdnīca (b.g.). Rìga: Zvaigzne ABC.

International Labour Organization (n. d.). Conventions. NOR MLEX Information System on International Labour Standards. Retrieved from http:// www.ilo.org/dyn/normlex/en/f?p=100o:1200o:3821381116919762:::: P12O0O INSTRUMENT SORT:4

Jarass, H.D., \& Pieroth, B. (2007). Grundgesetz für die Bundesrepublik Deutschland. Kommentar. München: Verlag C.H.Beck.

Katrougalos, G. (2012-2013). The Crisis of the European Social State. In Annuaire International des droits de l'homme, VII. 
Kaufmann, F.X. (2012). European Foundations of the Welfare State. New York, Oxford: Berghahn Books.

Konstitucionālo tiesību komisija. Par Latvijas valsts konstitucionālajiem pamatiem un neaizskaramo Satversmes kodolu. Rïga, 2012. gada 17. septembris.

Izgūts no http://www.president.lv/images/modules/items/PDF/17092012 Viedoklis_2.pdf

Kovalevevska, A. (2008, 26. aug.). Sociāli atbildīgas valsts princips. Jurista Vārds, 32(537). Kovalevska, A. (2009, 22. dec.). Tiesïbas uz atbilstošu dzives lïmeni. Jurista Vārds, $51 / 52(594 / 595)$.

Kovalevska, A. (2011). 109. pants. No Latvijas Republikas Satversmes komentäri. VIII nodaḷa. Cilvēka pamattiesības. Autoru kolektīvs R. Baloža zinātniskā vadībā. Rīga: Latvijas Vēstnesis.

Kovaḷevska, A. (2013). Latvijas Republika kā sociāli atbildīga valsts. No Tiesību interpretācija un tiesïbu jaunrade - kā rast pareizo lïdzsvaru. Latvijas Universitātes 71.zinātniskās konferences rakstu krājums. Rīga: LU Akadēmiskais apgāds.

Kūtris, G. (2009, 18. aug.). Tiesiskās paḷāvibas un sociāli atbildỉgas valsts principi. Jurista Värds, 33(576).

Kūtris, G., Ķinis, U., \& Osipova S. (2012). Satversmes tiesas tiesnešu 02.01.2012. atsevišķās domas lietā Nr. 2011-03-01. Izgūts no www.satv.tiesa.gov.lv.

Latvijas Satversmes Sapulces stenogrammu izvilkums (1920-1922). Latvijas Republikas Satversmes projekta apspriešana un apstiprināšana (2006). Rīga: Tiesu namu ağentūra.

Levits, E. (200o). Cilvēktiesību piemērošanas pamatjautājumi Latvijā. No Cilvēktiesības pasaulē un Latvijā. Rīgā: Izglitỉibas solì.

Levits, E. (2009, 21. apr.). Valsts oficiāāās informācijas pasniegšanai nedrìkst pieiet formāli. Jurista Vārds, 16(559). Izgūts no http://www.juristavards.lv/doc/190718valsts-oficialas-informacijas-pasniegsanai-nedrikst-pieiet-formali/

Levits, E. (2011). 91. pants. No Latvijas Republikas Satversmes komentäri. vIII nodala. Cilvēka pamattiesības. Autoru kolektīvs R. Baloža zinātniskā vadībā. Riga: Latvijas Vēstnesis.

Levits, E. (2012). Par veselïbas aprūpes reformas plānu, kas paredz izslēgt no veselïbas aprūpes sistēmas valsts trūcigākos iedzivotājus. No Konstitucionālās politikas seminārs. Semināra materiālu krājums. Bīrinịi.

Levits, E. (2013). 2. pants. Likuma pamatmērki. No J. Briede (red.), Administratīva procesa likuma komentāri. A un B daḷa. Rịga: Tiesu namu ağentūra.

Mathieu, B. (2012-2013). Principes constitutionnels de l'Etat social dans une perspective comparative. Annuaire International des droits de l'homme, VII.

Maunz, T., \& Dürig, G. (Begr.) (2014). Grundgesetz-Kommentar (Loseblatt), Bd. III. München: Verlag C. H. Beck, Stand: December, Art. 2O, VIII. Die Sozialstaatlichkeit.

Maurer, H. (2007). Staatsrecht I. München: Verlag C. H. Beck
Mucenieks, P. (1934). Sociālā likumdošana. I daḷa. Ievads un sociālās likumdošanas vispārējā mācì̉ba. II dala. Darba tiesības. (B. v.): Latvijas universitātes studentu padome.

Muckel, S. (2009). Sozialrecht (3. Auflage). München: Verlag C. H. Beck.

The Office of the United Nations High Commissioner for Human Rights (n.d.). Status of Ratification. Interactive Dashboard. Retrieved from http:// indicators.ohchr.org/

Parliamentary Council (1949). Basic Law for the Federal Republic of Germany. Retrieved from https://www.gesetze-im-internet.de/englisch_gg/index.html

Pleps, J., Pastars, E., \& Plakane, I. (2014). Konstitucionālās tiesïbas. Rīga: Latvijas Vēstnesis.

Ritter, G. A. (1991). Der Sozialstaat:Entstehung und Entwicklung im internationalen Vergleich. München: Oldenbourg Verlag.

Roca, J. G. (2012-2013). Taking Social Rights Seriously: Principle of Financial Sustainability. Annuaire International des droits de l'homme, VII.

Saaremäel-Stoilov, K. (2007). How to Handle a Double-edges Sword Safely: Protection of the Elements of the Principle of the Social State in the Constitutiona Jurisprudence of the Supreme Court of Estonia. Juridica International, 2

Saeima (1997, 21. okt.). Par valsts sociālo apdrošināšanu: Latvijas Republikas likums. Latvijas Vēstnesis, $274 / 276$.

Saeima (1998, 23. okt.). Grozijumi Latvijas Republikas Satversmē: Latvijas Republikas likums. Latvijas Vēstnesis, 308/312.

Saeima (2014, 8. jūl.). Grozijums Latvijas Republikas Satversmē: Latvijas Republikas likums. Latvijas Vēstnesis, 131 (5191).

Satversmes tiesa (1999). Par valsts akciju sabiedribas «Valsts nekustamā īpašuma ag̉entūra» «Nolikuma par kārtỉbu, kādā izīēejami brīvie dzivokḷi Valsts nekustamā īpašuma ağentūras pārvaldī̌anā esošajos namīpašumos» atbilstïbu likuma «Par valsts un pašvaldibu palïdzỉbu dzivokḷa jautājumu risināšanā» 2., 10. un 11. pantam, likuma «Par dzivojamo telpu îri» 40. pantam un likuma «Par valsts un pašvaldỉbu dzivojamo māju privatizāciju» pārejas noteikumu 4. punktam. 09.07.1999. spriedums lietā Nr.04-03(99). Izgūts no www.satv.tiesa.gov.lv

Satversmes tiesa (2001). Par likuma «Par valsts sociālo apdrošināšanu» Pāreja noteikumu 1. punkta atbilstibu Latvijas Republikas Satversmes 1. un 109. pantam, 1966. gada 16. decembra Starptautiskā pakta par ekonomiskajām, sociālajām un kultūras tiesībām 9. pantam un 11. panta pirmajai daḷai. 13.03.2001. spriedums lietā Nr. 2000-08-0109. Izgūts no www.satv.tiesa.gov.lv

Satversmes tiesa (2002). Par likuma «Par valsts pensijām» pārejas noteikumu 26. punkta atbilstibu Satversmes 91. un 109. pantam: 19.03.2002. spriedums lietā Nr. 2001-12-01. Izgūts no www.satv.tiesa.gov.lv

Satversmes tiesa (2004a). Par reǵionālās attīstības un pašvaldību lietu ministra 2003. gada 27. maijā pienemtā rīkojuma Nr. 2-02/57 «Par Jūrmalas pilsētas 
domes 24.10.2001. saistošo noteikumu Nr.17 «Par detālo plānojumu Jūrmalā, teritorijai starp Bulduru prospektu, Rotas ielu, 23. un 25.linijām» darbïbas apturēšanu», 2003. gada 2. jūnijā pieṇemto rìkojumu Nr. 2-02/60 «Par Jūrmalas pilsētas domes 09.10.2002. saistošo noteikumu Nr.10 «Par detālā plānojuma apstiprināšanu Jūrmalā, sabiedriskajam centram Vaivaros» darbïbas apturēšanu» un Nr. 2-02/62 «Par Jūrmalas pilsētas domes 07.11.2001. saistošo noteikumu Nr. 18 «Par detālā plānojuma apstiprināšanu Jūrmalā, zemesgabalam Bulduri 1001» darbibas apturēšanu» atbilstību Latvijas Republikas Satversmes 1.pantam. 09.03.2004. spriedums lietā Nr. 2003-16-05. Izgūts no www.satv.tiesa.gov.lv

Satversmes tiesa (2004b). Par likuma «Par obligāto sociālo apdrošināšanu pret nelaimes gadījumiem darbā un arodslimībām» 17. panta piektās daḷas atbilstibu Latvijas Republikas Satversmes 91. un 109. pantam. 26.03.2004. spriedums lietā Nr. 2003-22-01. Izgūts no www.satv.tiesa.gov.lv

Satversmes tiesa (2005a). Par Civilprocesa likuma 132. panta pirmās daḷas 3. punkta un 223. panta 6. punkta atbilstību Latvijas Republikas Satversmes 92. pantam. 17.01.2005. spriedums lietā Nr. 2004-10-01. Izgūts no www.satv.tiesa.gov.lv

Satversmes tiesa (2005b). Par Latvijas Republikas Krimināllikuma 253.2 panta pirmajā dạ̣ā iekḷautās normas «narkotisko un psihotropo vielu lietošana bez ārsta nozīmējuma» atbilstību Latvijas Republikas Satversmes 96. pantam. 26.01.2005. spriedums lietā Nr. 2004-17-01. Izgūts no www.satv.tiesa.gov.lv

Satversmes tiesa (2005c). Par Ministru kabineta 2005. gada 11.janvāra noteikumu Nr. 17 «Grozijumi likumā «Par nekustamā īpašuma piespiedu atsavināšanu valsts vai sabiedriskajām vajadzībām» » un 2005. gada 9. jūnija likuma «Grozijjumi likumā «Par nekustamā īpašuma piespiedu atsavināšanu valsts vai sabiedriskajām vajadzībām» » atbilstiibu Latvijas Republikas Satversmes 1. un 105. pantam. 16.12.2005. spriedums lietā Nr. 2005-12-0103. Izgūts no www. satv.tiesa.gov.lv

Satversmes tiesa (2006a). Par 2004.gada 20. decembra likuma «Grozijumi likumā «Par dzīvojamo telpu îri»» 13. panta atbilstību Latvijas Republikas Satversmes 1., 91. un 105. pantam. 08.03.2006. spriedums lietā Nr. 2005-16-01. Izgūts no www.satv.tiesa.gov.lv

Satversmes tiesa (2006b). Par likuma «Grozijumi Valsts sociālo pabalstu likumā» 1. panta dalas, ar kuru Valsts sociālo pabalstu likumā ieviests jauns 7.panta pirmās dalıas 3. punkts, un 2. panta atbilstibu Latvijas Republikas Satversmes 110. pantam. 02.11.2006. spriedums lietā Nr. 2006-07-01. Izgūts no www.satv. tiesa.gov.lv

Satversmes tiesa (2006c). Par Ministru kabineta 2004.gada 7. decembra noteikumu Nr. 1003 «Kārtība, kādā piešḳir un izmaksā bērna kopšanas pabalstu un piemaksu pie bērna kopšanas pabalsta par dviniem vai vairākiem vienās dzemdībās dzimušiem bērniem» 3.1. punktā ietvertās normas vārdu «un ne vairāk kā 392 lati mēnesī» atbilstibu Latvijas
Republikas Satversmes 91. pantam. 11.12. 2006. spriedums lietā Nr. 2006-1003. Izgūts no www.satv.tiesa.gov.lv

Satversmes tiesa (2007a). Par Limbažu pilsētas domes 2006.gada 25.janvāra saistošo noteikumu Nr. 4 «Limbažu pilsētas teritorijas plānojuma grafiskā dalıa un teritorijas izmantošanas un apbūves noteikumi» plānojuma, ar kuru zemes gabals Cēsu ielā 24 iekḷauts Limbažu pilsētas teritorijas Izmantošanas un nekustamo îpašumu lietošanas mērḳu grupas dabas pamatnes teritorijas vai brivās izbūves teritorijas mežaparku un parku teritorijā, atbilstību Latvijas Republikas Satversmes 105. pantam. 26.04.2007. spriedums lietā Nr. 2006-38-03. Izgūts no www.satv.tiesa.gov.lv

Satversmes tiesa (2007b). Par Streiku likuma 24. panta trešās dalas atbilstỉbu Latvijas Republikas Satversmes 108. pantam. 16.05.2007. spriedums lietã Nr. 2006-42-01. Izgüts no www.satv.tiesa.gov.lv

Satversmes tiesa (2007c). Par likuma «Par iedzivotāju ienākuma nodokli» 13. panta pirmās dalas 2. punkta vārdu «līdz 1996. gada 1.janvārim» un 13.panta pirmās daḷas 3. punkta atbilstību Latvijas Republikas Satversmes 91. pantam. 08.06.2007. spriedums lietā Nr. 2007-01-01. Izgūts no www.satv.tiesa.gov.lv

Satversmes tiesa (2008a). Par likuma «Par nodokliem un nodevām» (2000.gada 13. aprịla likuma redakcijā) 33.1. panta pirmās dạ̣as vārdu «ne biežāk kā vienu reizi trijos gados» atbilstību Latvijas Republikas Satversmes 1. pantam. 03.04.2008. spriedums lietā Nr. 2007-23-01. Izgūts no www.satv.tiesa.gov.lv

Satversmes tiesa (2008b). Par Latvijas Sodu izpildes kodeksa 50. panta otrās dạlas otrā teikuma atbilstibu Latvijas Republikas Satversmes 92. pantam. 09.05.2008. spriedums lietā Nr. 2007-24-01. Izgūts no www.satv.tiesa.gov.lv

Satversmes tiesa (2009a). Par 2009. gada 12. marta likuma «Grozijumi likumā «Par valsts pensijām»» 2. panta vārdu «valsts pensijas 2009. gadā pārskatitas netiek» atbilstibu Latvijas Republikas Satversmes 1. un 109. pantam. 26.11.2009. spriedums lietā Nr. 2009-08-01. Izgūts no www.satv.tiesa.gov.lv

Satversmes tiesa (2009b). Par likuma «Par valsts pensiju un valsts pabalstu izmaksu laika periodā no 2009. gada līdz 2012. gadam» 2. panta pirmās dạlas atbilstibu Latvijas Republikas Satversmes 1. un 109. pantam un 3. panta pirmās daḷas atbilstỉbu Latvijas Republikas Satversmes 1., 91., 105. un 109. pantam. 21.12.2009. spriedums lietā Nr. 2009-43-01. Izgūts no www.satv. tiesa.gov.lv

Satversmes tiesa (2010a). Par likuma «Par tiesu varu» pārejas noteikumu 7.punkta otrā teikuma un 17. punkta (2008. gada 14. novembra likuma redakcijā) atbilstibu Latvijas Republikas Satversmes 1., 83. un 107.pantam. 18.01.2010. spriedums lietā Nr. 2009-11-01. Izgūts no www.satv.tiesa.gov.lv

Satversmes tiesa (2010b). Par likuma «Par valsts pensiju un valsts pabalstu izmaksu laika periodā no 2009. gada līdz 2012. gadam» 5. panta pirmās daḷas atbilstỉbu Latvijas Republikas Satversmes 1., 91. un 110. pantam. 15.03.2010. spriedums lietā Nr. 2009-44-01. Izgūts no www.satv.tiesa.gov.lv 
Satversmes tiesa (2010c). Par likuma «Par obligāto sociālo apdrošināšanu pret nelaimes gadījumiem darbā un arodslimībām» 20. panta devitās daḷas atbilstibu Latvijas Republikas Satversmes 1., 91., 105. un 109.pantam, šã likuma 14. panta septîtās daḷas, kā arī likuma «Par obligāto sociālo apdrošināšanu pret nelaimes gadijumiem darbā un arodslimībām» 20. panta devitās dạ̦as (likuma redakcijā no 2004. gada 25. novembra līdz 2009. gada 16. jūnijam) un likuma «Grozijumi likumā «Par obligāto sociālo apdrošināšanu pret nelaimes gadijumiem darbā un arodslimỉbām»» 6. panta pirmās dạlas atbilstỉbu Latvijas Republikas Satversmes 1., 91. un 109. pantam. 29.10.2010. spriedums lietā Nr. 2010-17-01. Izgūts no www.satv.tiesa.gov.lv

Satversmes tiesa (2010d). Par 2009.gada 1. decembra likuma «Grozijumi likumā «Par iedzīvotāju ienākuma nodokli»» 6. panta (dạ̣ā par likuma «Par iedzivotāju ienākuma nodokli» 9. panta pirmās dạ̣as 3. punkta izslēgšanu) un likuma «Par iedzìvotāju ienākuma nodokli» 8. panta trešās dalas 13. punkta un 16.1 panta devītās dalas atbilstibu Latvijas Republikas Satversmes 1. un 105. pantam. 06.12.2010. spriedums lietā Nr. 2010-25-01. Izgūts no www.satv. tiesa.gov.lv

Satversmes tiesa (2011a). Par Ministru kabineta 2008. gada 25. augusta noteikumu Nr. 692 «Noteikumi par patērētāja kreditēšanas līgumu» 30. punkta atbilstību Latvijas Republikas Satversmes 64. un 105. pantam. 08.04.2011. spriedums lietā Nr. 2010-49-03. Izgūts no www.satv.tiesa.gov.lv

Satversmes tiesa (2011b). Par Ministru kabineta 2009. gada 2.jūnija noteikumu Nr. 511 «Grozijumi Ministru Kabineta 2004. gada 24. augusta noteikumos Nr. 740 «Noteikumi par stipendijām»» 1.1. punkta atbilstibu Latvijas Republikas Satversmes 91. un 112. pantam. 06.05.2011. spriedums lietā Nr. 2010-57-03. Izgūts no www.satv.tiesa.gov.lv

Satversmes tiesa (2011c). Par Kredītiestāžu likuma 59.5 panta atbilstïbu Latvijas Republikas Satversmes 1. un 105.pantam. 19.10.2011. spriedums lietā Nr. 201071-01. Izgūts no www.satv.tiesa.gov.lv

Satversmes tiesa (2011d). Par Publisko iepirkumu likuma 39. panta pirmās dalą 6. punkta atbilstïbu Latvijas Republikas Satversmes 91. un 105. pantam. 03.11.2011. spriedums lietā Nr. 2011-05-01. Izgūts no www.satv.tiesa.gov.lv

Satversmes tiesa (2011e). Par likuma «Par valsts sociālo apdrošināšanu» 5. panta ceturtās dạ̦as un 21. panta 2.1 dalas atbilstỉbu Latvijas Republikas Satversmes 1. un 109. pantam. 19.12.2011. spriedums lietā Nr. 2011-03-01. Izgūts no www. satv.tiesa.gov.lv

Satversmes tiesa (2012a). Par Valsts fondēto pensiju likuma 4. panta pirmās dalas atbilstibu Latvijas Republikas Satversmes 1. un 109. pantam. 25.01.2012. spriedums lietā Nr. 2011-08-01. Izgūts no www.satv.tiesa.gov.lv

Satversmes tiesa (2012b). Par Maksātnespējas likuma 62. panta pirmās daḷas un Civilprocesa likuma 363.2 panta otrās dalas normām, ciktāl tās neparedz tiesas tiesỉbas atbrivot personas no depozìta iemaksas, atbilstibu Latvijas
Republikas Satversmes 92. pantam. 20.04.2012. spriedums lietā Nr. 2011-16-01. Izgūts no www.satv.tiesa.gov.lv

Satversmes tiesa (2012c). Par Ministru kabineta 2001. gada 13. marta noteikumu Nr. 120 «Rezidentu sadales un rezidentūras finansēšanas noteikumi» 3.1 5. apakšpunkta un 11. punkta un Ministru kabineta 2009. gada 25. augusta noteikumu Nr. 972 «Rezidentu sadales un rezidentūras finansēšanas noteikumi» 11. punkta atbilstibu Latvijas Republikas Satversmes 91. un 106.pantam. 03.05.2012. spriedums lietā Nr. 2011-14-03. Izḡūts no www.satv.tiesa.gov.lv

Satversmes tiesa (2014). Par likuma «Par dzivojamo telpu îri» 8. panta pirmā teikuma atbilstibu Latvijas Republikas Satversmes 105. pantam. 07.07.2014. spriedums lietā Nr. 2013-17-01. Izgūts no www.satv.tiesa.gov.lv

Satversmes tiesa (2015a). Par Dabas resursu nodokḷa likuma 3. panta pirmās daḷas 1.punkta «f» apakšpunkta, 19.1 panta un Ministru kabineta 2014.gada 14. janvāra noteikumu Nr. 27 «Grozijumi Ministru kabineta 2007.gada 19. jūnija noteikumos Nr. 404 «Dabas resursu nodokḷa aprēḳināšanas un maksāšanas kārtība un kārtība, kādā izsniedz dabas resursu lietošanas ațlauju»» atbilstibu Latvijas Republikas Satversmes 105. pantam. 25.03.2015. spriedums lietā Nr. 2014-11-0103. Izgūts no www.satv.tiesa.gov.lv

Satversmes tiesa (2015b). Par Civilprocesa likuma 635. panta sestās daḷas, ciktāl tā attiecas uz sprieduma izpildišanas pagriezienu lietās par darba samaksas piedziṇu, atbilstibu Latvijas Republikas Satversmes 92. panta pirmajam un trešajam teikumam. 16.04.2015. spriedums lietā Nr. 2014-13-01. Izgūts no www.satv.tiesa.gov.lv

Satversmes tiesa (2015c). Par Ministru kabineta 2010.gada 16. marta noteikumu Nr. 262 «Noteikumi par elektroenerǵijas ražošanu, izmantojot atjaunojamos energoresursus, un cenu noteikšanas kārtỉbu» 100. punkta atbilstību Latvijas Republikas Satversmes 64. pantam. 14.10.2015. spriedums lietā Nr. 2015-05-03. Izgūts no www.satv.tiesa.gov.lv

Schmidt-Bleibtreu, B., \& Klein, F. (1995). Kommentar zum Grundgesetz (8. Auflage). Neuwied, Kriftel, Berlin: Luchterhand.

Sodan, H., \& Ziekow, J. (2007). Grundkurs öffentliches Recht. München:Verlag C.H.Beck. Strupišs, A. (2015). Privāttiesỉbas un to principi Senāta judikatūrā: vispārīgs pārskats. No Bïrinuu vasaras skolas 2015 materiālu krājums «Vispārējie tiesību principi-tapšana, tvērums, piemērošana». Bïrini.

UK Parliament Website (n.d.). The 1833 Factory Act. Retrieved from http:// www.parliament.uk/about/living-heritage/transformingsociety/ livinglearning/19thcentury/overview/factoryact/

United Nations (1948). Universal Declaration of Human Rights. Retrieved from http://www.ohchr.org/EN/UDHR/Pages/Language.aspx?LangID=eng

United Nations (1966). International Covenant on Economic, Social and Cultural Rights. Retrieved from http://www.ohchr.org/EN/ProfessionalInterest/ Pages/CESCR.aspx 
Vācijas Federālā konstitucionālā tiesa (1990). 1990. gada 29. maija spriedums lietā Nr. 1 BvL 20, 26, 184, 4/86 (BVerfGE 82, 60). Izgūts no http://www.servat.unibe. $\mathrm{ch} / \mathrm{dfr} / \mathrm{bvo8} 206 \mathrm{o}$.html

Vācijas Federālā konstitucionālā tiesa (1992). 1992. gada 25. septembra spriedums lietā Nr. 2 BvL 5, 8, 14/91 (BverfGE 87,153). Izgūts no http://www.servat.unibe. $\mathrm{ch} / \mathrm{dfr} / \mathrm{bvo87153.html}$

Vācijas Federālā konstitucionālā tiesa (2010). 2010. gada 9. februāra spriedums lietā Nr. 1 BvL 1/o9, 1 BvL 3/o9, 1 BvL 4/o9 (BVerfGE 125, 175). Izgūts no http://www. bundesverfassungsgericht.de/SharedDocs/Entscheidungen/DE/2010/o2/ ls20100209_1bvlooo109.html

Vildbergs, H.J., Messeršmits, K., \& Niedre, L. (2004). Pilsonis tiesiskā valstī (mācību līdzeklis). Rīga: Latvijas Universitāte.

Zacher, H.F. (2008). Abhandlungen zum Sozialrecht II. Heidelberg: C.H. Müller Verlag. Калашников, С. В. (2002). Функииональная теория соииального государства. Москва: Экономика. 


\section{Sociālās rīcībpolitikas pārvaldības izaicinājumi un krīzes mācības}

Analizējot sociālo jomu, pētnieki parasti aplūko sociālo politiku kā tādu rīcībpolitiku, kas vērsta uz sociālo pakalpojumu sniegšanu. Tomēr cita sociāāās politikas izpratne paredz krietni plašāku skatỉjumu, sociālo politiku skatot kā lēmumu, rīcību un programmu kopumu, kas ir vērsts uz visu iedzīvotāju labklājības un dzīves kvalitātes palielināšanu. Šajā skatỉjumā sociālā politika kḷūst par visaptverošu kopumu, kur ir svarīgi katrā atsevišķā rīcibpolitikas jomā izcelt tās aktivitātes, kas ir vērstas uz minēto mērku sasniegšanu (piemēram, Walsh, Stephens, \& Moore, 2000). Proti, nodokḷu palielināšana vai samazināšana nav tikai valsts budžeta un fiskālās politikas jautājums, bet vistiešāk skar dažādas iedzivotāju grupas. Uzṇēmējiem nodoklu izmainas var ietekmēt izvēlēto biznesa stratēgoiju, savukārt indivīdiem nodokḷu izmaiṇas vistiešāk ietekmē personigo labklājību. Tas nozīmē, ka persona var nebūt sociālo pakalpojumu klients, bet vienlaikus var būt sociālās politikas subjekts.

Šìs nodalas mērkịis ir apskatìt sociālo rīcībpolitiku no pārvaldības un ekonomiskās krīzes perspektīvas, ḷajot identificēt izaicinājumus un gūtās mācības. Nodaḷas sākumā tiks izskaidrots publisko pakalpojumu jēdziens un dažādas pārvaldības pieejas. Pēc tam tiks veikta sociālās politikas galveno attīstības plānošanas dokumentu analīze no pārvaldības perspektīvas, tā identificējot pašreizējos un nākotnes izaicinājumus. Politikas plānošanas dokumentu analīze balstīsies uz vairākiem kritērijiem. Pirmkārt, kāda ir sociālo jomu reglamentējošās pamatnostādnēs ietvertā izpratne par pārvaldỉbu. Otrkārt, kāds ir attīstības plānošanas dokumentos ietvertais redzējums par attiecigās jomas politikas attīstïbu. Treškārt, kā tiek mērìts rīcībpolitikas progress. Tā kā pārvaldības jēdziens ir daudzškautnains, tad atseviškā sadalā izskaidrots Latvijas un Lietuvas sociālās jomas darbinieku skatijums uz šis jomas pārvaldību krīzes laikā, lai izprastu rīcībpolitikas ilgtermina ietekmi ne tikai Latvijā, bet Baltijas valstīs kopumā.

Vispārējās nozīmes

pakalpojumu principi

Eiropā un Latvijā

Eiropas Zalajā grāmatā par vispārējās nozīmes pakalpojumiem (Green Paper on Services of General Interest, 2003, pp.1620) ir definēti galvenie vispārējās nozī-

mes pakalpojumu principi-universālisms, pēctecība, pakalpojuma kvalitāte, pieṇemama un saprātīga cena, kā arī lietotāju aizsardzība. Balstoties uz šiem principiem, ir arī noteiktas vispārējās nozīmes pakalpojumu svarīgākie nosacījumi - tiem ir jābūt labi funkcionējošiem, pieejamiem, par saprātīgu cenu un kvalitativiem (European Commission, 2004, p.3).

Universālisms nosaka: pakalpojumi ir pieejami visiem iedzīvotājiem visā valsts teritorijā par saprātīgu cenu (Green Paper on Services of Genera Interest, 2003, p. 16). Pēctecība Zalās grāmatas izpratnē ir tas, ka vispārējās 
nozīmes pakalpojums tiek sniegts bez pārtraukumiem, ierobežojumiem vai situācijām, kurās pakalpojums vispār nav pieejams (Green Paper on Services of General Interest, 2003, p. 17). Pakalpojumu kvalitātes princips Zaḷās grāmatas izpratnē nozīmē, ka pakalpojumu kvalitātes līmenis tiek regulāri mērìts, izmantojot attiecīgus rezultatìvos rāditājus. Visbeidzot, pieņemama cena kā princips ir attiecināma uz tiem vispārējās nozīmes pakalpojumiem, par kuriem iedzīvotāji maksā tiešā veidā - skaidrā vai bezskaidrā naudā. Pieņemamās cenas princips arī noteic, ka publiskās pārvaldes sniegtie pakalpojumi nedrīkst būt tik dārgi, ka tos nevar baudīt visas iedzivotāju grupas.

Pēc būtỉbas vispārējās nozīmes pakalpojumiem ir jāveicina sociālā un teritoriālā kohēzija, lai panāktu labklājības lìmeṇa pieaugumu un sociālās nevienlīdzības mazināšanu (European Parliament, 2010, p. 14). Sociālā kohēzija ir nevis izolēta rīcībpolitika, bet gan sabiedrības un publiskās pārvaldes kopējā spēja un prasme nodrošināt labklājību visiem tās locekliem. Tādēl vispārējās nozīmes pakalpojumi ir vērsti uz to, lai tiktu samazināta polarizācija starp iedzīvotājiem un lai, palīdzot vienai mērḳgrupai, nepasliktinātu citas stāvokli (European Parliament, 2010, p. 22).

Vispārējās nozīmes pakalpojumi Latvijā visbiežāk tiek apzīmēti ar terminu «publiskie pakalpojumi», pieņemot, ka tos sniedz valsts pārvaldes iestādes un pašvaldỉbas (Valsts kanceleja, 2006). Taču precīza definīcija, kas ir «publiskais pakalpojums» un kādam tam ir jābūt, Latvijā nav pieejama, un tas sniedz plašas interpretācijas iespējas nozarēs (Reinholde, 2012, 163.194.lpp.). Arī Eiropas Savienības dalïbvalstīs pastāv dažādi skatijumi par to, kas ir pakalpojumi un kas nav, un šādas atškirīgas interpretācijas izriet no atškirīgām administratīvām tradīcijām. Tiesa, 2017. gada 4. jūlijā tika pieņemti Ministru kabineta noteikumi Nr. 399 «Valsts pārvaldes pakalpojumu uzskaites, kvalitātes kontroles un sniegšanas kārtỉba», kuros definēts, ka valsts pārvaldes pakalpojums ir «secīgu darbibu kopums, kas dod guvumu vai ir obligāts privātpersonai un ko sniedz valsts pārvaldes pakalpojuma turētājs, îstenojot valsts pārvaldes funkcijas saskaṇā ar ārējiem normatīvajiem aktiem vai saskanāa ar deleǵêtiem valsts pārvaldes uzdevumiem».

ES tiek lietoti četri dažādi termini, runājot par vispārējās nozīmes vai publiskajiem pakalpojumiem. Šie termini ir: «vispārējās nozīmes pakalpojumi» (services of general interest -SGI), «vispārējās nozīmes ekonomiskie pakalpojumi» (services of general economic interest-SGEI), «vispārējās nozimes neekonomiskie pakalpojumi» (non economic services of general interest-NESGI) un «vispārējās nozīmes sociālie pakalpojumi» (social services of general interest-SSGI) (CEEP, 2010). Vispārējās nozìmes sociālie pakalpojumi ir vissvarīgākie sociālās labklājības nodrošināšanai. Vispārējās nozimes neekonomiskie pakalpojumi ietver valsts pienākumus tieslietu un iekšlietu jomās, un katra dalībvalsts pati regulē šo pakalpojumu sniegšanu (Commission of the European Communities, 2007). Vispārējās nozīmes sociālie pakalpojumi ES tiek dalīti divās dalās - 1) obligātā un brīvprātīgā valsts sociālas apdrošināšanas sistēma un 2) citi pakalpojumi, kurus tieši saṇem persona, kad tā ir palikusi bez darba, sasniegusi pensijas vecumu vai saslimusi (Commission of the European Communities, 2006).

Jāatzīst, ka Sociālo pakalpojumu un sociālās palīdzības likums sniedz gana skaidru vispārējās nozīmes sociālo pakalpojumu definīciju, kas ḷauj izprast šo pakalpojumu dabu. Respektīvi, likuma mērḳis ir «noteikt sociālā darba, karitatīvā sociālā darba, sociālās aprūpes, sociālās rehabilitācijas, profesionālās rehabilitācijas pakalpojumu (turpmāk - sociālie pakalpojumi) un sociālās palīdzības sniegšanas un saṇemšanas principus, to personu loku, kurām ir tiesības sanemt šos pakalpojumus un palīdzību, kā arī sociālās aprūpes, sociālās rehabilitācijas un profesionālās rehabilitācijas pakalpojumu samaksas un finansēšanas principus» (Saeima, 2002). Taču aktuāls ir jautājums, vai Latvijā kādā normatīvā aktā ir noteikti labklāīibas mērkị? Vai labklājỉbas mērkiem ir jābūt definētiem normatīvajos aktos? Varbūt ir pietiekami ar to, ka Latvija ir apṇēmusies ieviest sociāli atbildīgas valsts principus, kas ietverti Satversmè?

\section{Sociālās jomas izaicinājum}

Reaǵèjot uz jauna tipa problēmām režìma transformācijas procesā, 90. gadu sākumā valdība nolēma veidot sociālās drošỉbas sistēmu, kuras centrā būtu pašvaldību izveidoti sociālie dienesti (Moors, 2007, 10.-13. lpp.). Jāṇem vērā tas, ka 9o.gadu sākumā Latvija piedzīvoja trīskāršu transformāciju. Politiskās sistēmas maina notika paralēli ekonomiskām reformām un administratīviem pārkārtojumiem. Arī ekonomiskā situācija bija ārkārtīgi sarežğìta, jo iedzivotājiem nācās pielāgoties jaunām parādībām, kā cenu celšanās, inflācija un bezdarbs. Tādējādi valdības lēmums palīdzēt iedzīvotājiem tikt gaalā ar komunālo maksājumu slogu bija svariggs gan no labklājibas politikas veidošanas perspektīvas, gan arī no pārvaldības perspektīvas. Šãds lēmums bija kā signāls tam, ka varētu veidoties labklājibas politika, kas palīdzētu krīzē nonākušiem indivìdiem. Taču uzsākto sociālās politikas attīstību satricināja 2008. gada ekonomiskā krīze.

Tieši labklājības jomā 2008. gads iezīmēja būtiskas izmainas, jo ekonomiskās lejupslīdes rezultātā valdībai nācās samazināt valsts budžeta izdevumus. Vienlaikus ekonomiskās lejupslīdes dēl strauji pieauga bezdarba apjoms, un jau 2009. oktobrī tas sasniedza 19,7\% atzīmi (Latvijā augstākais, 2017). Tobrìd Latvijas ekonomika tika dēvēta par «vienu no slimākajām ekonomikām Eiropā» (BBC, 2009) un ekonomiskās problēmas vistiešākajā veidā ietekmēja sociālo politiku. «Latvijas ekonomikas stabilizācijas un izaugsmes atjaunošanas programma» (Ministru kabinets, 2008) bija galvenais dokuments sarunu procesā ar Starptautisko Valūtas fondu (SVF) un Eiropas 
Komisiju (EK) par starptautiskās palīdzības sanemšanu, lai sabalansētu valsts izdevumus ar ieņēmumiem. Programma paredzēja «.. izglìtības, veselības un citu publisko pakalpojumu sektoru reformas, dalēji samazinot, dalēji pārstrukturējot šajos sektoros nodarbinātos cilvēkresursus» (Ministru kabinets, 2008). Tomēr programmā tika uzsvērts, ka jāsaglabā sociālās aizsardzības pasākumi «iedzìvotāju miera stiprināšanai» (Ministru kabinets, 2008, 2.lpp.). Tādējādi pat situācijā, kad nepieciešami radikāli valsts budžeta taupišanas pasākumi, valdība tomēr apzinājās, ka noteikts sociālā atbalsta pasākumu līmenis ir jāsaglabā gan sociālās drošỉbas nodrošināšanai, gan arī kā kompensācija par citās jomās samazinātajiem publiskajiem pakalpojumiem.

Nodomu vēstulēs SVF un Saprašanās memorandā ar EK ieḷautās apnemšanās ir jāskata kontekstā ar politikas plānošanas dokumentos ietverto, tā laujot skaidrāk izprast pārvaldỉbas modeli labklājības attīstìbai. Tā 2008. gada nogalē Latvijas valdība nosūtija SVF nodomu vēstuli, kurā līdzās aiznēmuma pieškiršanas lūgumam tika iekḷautas arì Latvijas puses apnemšanās veikt vairākas darbības, kurām vajadzētu stabilizēt finanšu situāciju (Finanšu ministrija, 2008). Lai arī jēdziens «strukturālās reformas» publiskajā telpā ir ieguvis negatīvu nozīmi un ar to tiek apzīmēti tikai jau notikuši tehniski budžeta samazināšanas pasākumi, tomēr sākotnēji šis jēdziens tika lietots, lai uzsvērtu nepieciešamību mainīt lïdzšinējo rīcībpolitiku ieviešanas praksi. Tādējādi teorētiski līdz ar finanšu samazināšanu pastāvēja iespēja arī mainìt rīcībpolitiku stilu un pieeju - tas kaut kādu iemeslu pēc netika darìts iepriekš. Latvijas valdība apnēmās veikt plašas reformas izglìitibas, veselības aprūpes, civildienesta un valsts pārvaldes sistēmā (Finanšu ministrija, 2009b, 2.-3.lpp.). Šajā gadijjumā neatkarīgi no reformu satura un apjoma tika skarti publiskie pakalpojumi attiecīgajās jomās. Turklāt iezīmējās Latvijā jau zināmā situācija, ka ikvienas nozares pārvaldība ir pietiekami izolēta un nesaistīta ar citu nozari, aizmirstot to, ka nav iespējams rīcibpolitikas mākslīgi nodalīt.

Jau 2009. gada vidū valdība bija samazinājusi neapliekamo minimumu (no 90 līdz 35 latiem), uzsākusi reformas izglitiibas un veselības aprūpes jomā, kā arī samazinājusi sociālos izdevumus (piemēram, pensijas, maternitātes pabalstus) (Finanšu ministrija, 2009a, 5. lpp.). Tiesa, vienlaikus tika piedāvāts arī kompensācijas mehānisms - sociālās drošības tîkls, kuram bija jāakumulēe ekonomiskās lejupslīdes trieciens iedzīvotājiem ar zemiem ienākumiem. 2010. gada vidū valdỉba bija gatava palielināt sociāāās drošības tìkla stratēǵijai paredzētos izdevumus, tā veicinot aktivitāti darba tirgū, kaut gan tika arī veiktas izmainas sociālo pabalstu sistēmā, tā iezimējot atsevišḳu pabalstu samazināšanu (piemēram, pabalstu bezdarba vai slimỉbas gadijumāā) (Finanšu ministrija, 2010, 4.lpp.). Tajā pašā laikā iestāžu lēmums krizes laikā pāriet uz četru dienu darba nedēḷ ${ }^{1}$, tā kompensējot darbinieku atalgojuma
2 Šeit un turpmāk viedās pārvaldibas paziOrganization (2011).

samazinājumu, ir jāskata arī no pašu iestāžu darbinieku labklājības perspektīvas. 2011. gadā valdība sniedza pārskatu SVF un EK par paaugstinātajiem nodokḷiem (pievienotās vērtỉbas nodokli, dienesta autotransporta nodokli, darbinieku sociālās apdrošināšanas iemaksām, nekustamā īpašuma nodokli) un pensiju otrā līmeṇa samazinājumu (Finanšu ministrija, 2011, 5.lpp.). Turklāt turpinājās arì budžeta līdzekḷu subsīdiju samazinājums veselības, sociālās aizsardzības un izglitīibas jomā (Finanšu ministrija, 2011, 5.lpp.). Eiropas Parlaments tika norādījis, ka vispārējās nozìmes pakalpojumi ekonomiskās lejupslīdes laikā var būt kā efektîvs buferis, lai nodrošinātu pakalpojumu sanemšanu visiem iedzìvotājiem par saprātīgu cenu (European Parliament, 2010, p. 22), tādēl tajā mirklī sociālās drošỉbas tîkls bija instruments, kā radìt līdzsvaru starp labklājỉbas zudumu vienā jomā un vienai sociālai grupai par labu citām sociālām grupām.

Pārvaldība sociālajā jomā:

formālais skatijums

Vienlaikus jebkuras rīcibpolitikas formulēšana un ieviešana saistās ar noteiktu pārvaldības sistēmu. Šajā gadījumā svarīgss ir jautājums, vai Latvijā izveidotā pārvaldības sistēma veicina drošību un labklājību? Uz šo jautājumu var atbildēt, aplūkojot dažādus datus. Pirmkārt, ir svarīgs pats sociālajā sistēmā strādājošo viedoklis. Otrkārt, analizējot labklājības jomu, ir jāapskata svarīgākie rīcībpolitikas plānošanas dokumenti, kuri piedāvā formalizētu redzējumu par nākotni. Tiesa, ne vienmēr rīcībpolitikas plānošanas dokumentos ietvertais tiek realizēts.

Skaidrības labad jānorāda, ka Latvijā vēl arvien daudz biežāk runā par labu pārvaldību, nevis viedu pārvaldību tā vienkāršā iemesla dẹl, ka laba pārvaldība kā jēdziens ir iedzīvojusies birokrātiskajā diskursā, kamēr viedā pārvaldība šķiet svešāds un mazliet nesaprotams jēdziens (Reinholde, 2013, 22.-27.lpp.). Tiesa, jēdzienu «viedā pārvaldība» lieto gan Pasaules Veselības organizācija, gan Eiropas Savienība, uzsverot, ka valstij procesi ir jāorganizē tā, lai iedzivotāji un uznēemumi sanemtu valsts sniegtos pakalpojumus efektīvi (World Health Organization, 2011; European Commision, 2012). Respektivi, viedā pārvaldỉba pienem, ka, jau veidojot rīcībpolitikas, ir jānodrošina starpinstitucionāla perspektīva un sadarbỉba, lai galapatēēētājs iegūtu tādu pakalpojumu, kas nodrošina kompleksu problēmu risinājumu (World Health Organization, 2011; European Commision, 2012). Turpretī laba pārvaldība vairāk koncentrējas uz to, lai process, kurā veidojas pakalpojumi, ir atbilstoši organizēts.

Lai noteiktu, vai Latvija tuvojas viedai pārvaldībai, ir vērts pievērst uzmanību sešām viedās pārvaldības pazīmēm. ${ }^{2}$ Pirmā pazime: viedā pārvaldība jāsaista ar to, ka rīcībpolitikās ir ietverts tālredzịgs skatỉjums. Otrā pazìme: lēmumu pienemšana balstās uz pierādijjumiem un evidencēm. Trešā 
pazīme: iestādes un institūcijas ir spējigas vienoties par kopīgu rīcību sarežġitas problēmas risināšanai neatkarīgi no resoriskās padotības. Ceturtā viedās pārvaldības pazīme: pirms kārtējo rīcỉbpolitikas plānošanas dokumentu izstrādes tiek novērtēti iepriekšějie dokumenti. Piektā pazīme: apstiprinātas rīcībpolitikas dokumenta ieviešanas gaitā tiek veikta uzraudzība un nepieciešamās korekcijas. Visbeidzot, sestā pazime: rīcībpolitikā tiek aplūkoti vairāku, nevis tikai vienas vai divu dominējošo sociālo grupu ieguvumi un zaudējumi attiecīgajā jomā.

Teorētiskā perspektîvā tagad runā par jauno publisko pārvaldību (New Public Governance), ko veido piecas sastāvdalas: sociālpolitiskā pārvaldība, rīcībpolitiku pārvaldība, administratīvā pārvaldỉba, līgumu pārvaldība un tīklu pārvaldība (Osborne, 2010, pp. 8-9). Katra no jaunās publiskās pārvaldības sastāvdaḷām koncentrējas uz atsevišḳu jomu, kas var ietekmēt pārvaldību. Tā sociālpolitiskā pārvaldība koncentrējas uz iestāžu attiecībām ar sabiedrību, bet rīcībpolitiku pārvaldỉba aplūko, kā rīcibpolitiku veidotāji savstarpēji sadarbojas, lai nodrošinātu rīcibpolitiku procesu (Osborne, 2010, pp. 8-9). Attiecīgi administratīvās pārvaldỉbas uzmanības centrā ir efektīvu rīcībpolitiku ieviešana un publiskās pārvaldes spēja un prasme reağēt uz mūsdienu sarežğìtajām problēmām, bet līgumu pārvaldība ir jāsaista ar līgumattiecībām iestāžu starpā, lai sniegtu publiskos pakalpojumus. Visbeidzot, tikklu pārvaldība apzīmē starpinstitūciju tìklu un sadarbības lomu publisko pakalpojumu sniegšanai.

Nacionālais attīstỉbas plāns (NAP) 2007--2013.gadam (Reǵionālās attīstības un pašvaldību lietu ministrija, 2006) paredzēja pārvaldỉbas mehānismus, ar kuru palīdzību varētu sasniegt tajā noteiktos mērkus. Konkrēti, 2006. gadā bija skaidrs, ka publiskās pārvaldes iestādēm jādarbojas tā, lai to darba organizācijā tiek nodrošināta publisko pakalpojumu pieejamỉba un kvalitāte (Reğionālās attīstïbas un pašvaldību lietu ministrija, 2006, 26.lpp.). NAP 2007.-2013. gadam tika definētas arī citas labas pārvaldības pazìmes - komunikācija ar sabiedrību, ilgtermiṇa plānošana un resursu kontrole. NAP 2007.-2013. gadam paredzēja «visa veida pakalpojumu «minimālā groza» izstrādi», radot gan priekšnoteikumus šo pakalpojumu saṇemšanai, gan arī mazinot reğionālās atškiirības (Reğionālās attīstības un pašvaldību lietu ministrija, 2006, 38. lpp.). Nacionālajā attīstïbas plānā bija stratēgiskais virziens «Cilvēka labklājības kāpums», kur veselïbas aprūpe, ieklaujošs darba tirgus un sakopta apkārtējā vide aplūkota savstarpējā sinerğijāa, lai nodrošinātu labklājības kāpumu. Tas mudina secināt, ka ar tīklu pārvaldības palīdzību izvirzìtie mērḳi tiktu sasniegti.

Savukārt «Latvijas Nacionālais attīstības plāns 2014.-2020. gadam» akcentē indivìda atbildību savas labklājibas veidošanā, uzsverot, ka bezdarba gadījumā būs «pieejams îss, koncentrēts un stimulējošs valsts atbalsts», un nosakot, ka valsts un pašvaldỉbu iestāžu sniegtie pakalpojumi būs pieejami elektroniski un vienotajos klientu apkalpošanas centros (Pārresoru 3 Šis piecas spēkā esošãs nostādnes sociālo pakalpojumu attistīibai 2014.2020. gadam», «Ieklaujošas nodarbinātibas pamatnostādnes 2015.-2020. gadam «Apvienoto Nāciju Organizācijas Konvencijas par personu ar invaliditāti tiesibām istenošanas pamatnostādnes 2014-2020.gadam", «Profesionāla sociālā darba attistibas pamatnostādnes 2014.-2020.gadam", «Darba aizsardzibas politikas pamatnostādnes 2016.-2020. gadam». koordinācijas centrs, 2012, 9. lpp.). Šajāa attīstības plānā ir formulēta prioritāte «Cilvēka drošumspēja», kas ietver gan publiskos pakalpojumus, gan iestāžu koordinētu darbību labklājības veicināšanai. Turklāt šis attīstỉbas plāns runā arī par tik svarīgu parādību kā ienākumu plaisas samazināšana starp dažādām sociālām grupām un par ienākumu pietiekamību, kas ir būtiski gan subjektīvai drošỉbai, gan arī objektīvs pamats dzìvei bez sociālās palīdzības. Tādēl attīstības plānā iezìmētie rīcības virzieni «Cienīgs darbs», «Stabili pamati tautas ataudzei», «Kompetenču attīstiba», «Vesels un darbspējigs cilvēks» un «Cilvēku sadarbïba, kultūra un pilsoniskā līdzdalība kā piederības Latvijai pamats» (Pārresoru koordinācijas centrs, 2012, 34.lpp.) ieskicē to, ka labklājības politika ir kompleksa un būtu jāuzskata par horizontālo prioritāti.

Labklājības jomā ir politikas plānošanas dokumenti, kas nosaka rīcību sociālās politikas, sociālās apdrošināšanas un sociālo pakalpojumu sfērā. Tieši fragmentētas pieejas dēl, izlasot politikas plānošanas dokumentu, ir diezgan grūti uzzīmēt nākotnes labklājības politikas modeli un tã pārvaldības shēmu. Ministru kabineta noteikumi Nr. 300 «Ministru kabineta kārtības rullis» nosaka gan rīcībpolitiku sadalījumu jomās, gan arī rīcībpolitikas plānošanas dokumentu savstarpējo saistỉbu un hierarhiju (Ministru kabinets, 2009). Minētie Ministru kabineta noteikumi labklājības jautājumus skata kā «nodarbinātības un sociālo politiku» ar vairākām rīcībpolitika nozarēm - darba politiku, sociālo aizsardzību, dzimumu līdztiesību, sociālo ieklaušanos, bērnu un ǵimenes politiku. Turklāt saskanā ar Ministru kabineta noteikumiem ir paredzētas arī rīcībpolitikas apakšnozares. Tā, piemēram, darba politikai ir vairākas apakšnozares - darba tiesiskās attiecības un sociālais dialog̣s, minimālā darba alga, nodarbinātības veicināšana un bezdarba mazināšana, kā arī darba aizsardzība. Savukārt sociālās aizsardzības nozares apakšnozares ir sociālā apdrošināšana, valsts sociālie pabalsti, sociālā aprūpe, sociālā rehabilitācija, profesionālā rehabilitācija, tehniskie palīglīdzekḷi, sociālais darbs, sociālā palīdzība un invalīdu vienlīdzīgas iespējas.

Konstatēts, ka 2015.gada 1. oktobrī datubāzē polsis.mk.gov.lv ir pieejamas piecas pamatnostādnes ${ }^{3}$, kurām būtu jāieskicē turpmākais attīstỉbas scenārijs šajā jomā. Visas atlasītās pamatnostādnes tika analizētas pēc vienotiem kritērijiem, pievēršot uzmanību tam, cik detalizēti un precīi ir noteikts pakalpojumu apjoms, tas, kāda ir pārvaldības sistēma un redzējums pārvaldības attīstībai, vai pamatnostādnēs ir noteikta progresa mērī̌sanas sistēma.

Kopumā jāsecina: lai arī pamatnostādnes ir vidēja termiṇa plānošanas dokuments, tās diemžēl nesniedz redzējumu par to, kādus labumus sabiedrība varētu sagaidīt pēc septiniiem gadiem. Sociālās politikas plānošanas dokumenti ir tendēti sociālos pakalpojumus definēt jau pierastā 
institucionālā sociālās jomas ietvarā. «Pamatnostādnes sociālo pakalpojumu attīstībai 2014.-2020. gadam» veltītas sociālo pakalpojumu attīstībai kontekstā ar vispārējās nozīmes pakalpojumu izpratni un pieeju Eiropā. Turklāt šis ir tās pamatnostādnes, kas pietiekami skaidri iezimē redzējumu par to, ka ir jāmaina vērtējums par sociālo pakalpojumu lomu un nozīmi sabiedrībā. Respektīivi, pamatnostādṇu skatijumā sociālo pakalpojumu vērtējums ir jābalsta uz to, cik lielā mērā, saṇemot sociālos pakalpojumus, indivìds ir spējis iekḷauties sabiedrībā, darba tirgū, izglìtības sistēmā.

Savukārt no pārvaldības perspektīvas rīcībpolitikas plānošanas dokumentos valda jomas attīstỉbai svarīga tendence, ka attīstās un aktīvi strādā dažādas sabiedriskās organizācijas, biedrības, nodibinājumi, kas dod savu ieguldījumu sociālās politikas veidošanā. Tajā pašā laikā Labklājības ministrijas rīcībā paliek uzraudzība un kontrole, izmantojot pārskatus un pārbaudes. Liels skaits iesaistito institūciju nodrošina interešu lïdzsvarošanu, bet vienlaikus veicina institucionālo fragmentāciju, kur katra institūcija primāri lūkojas uz problēmām no savas kompetenču perspektīvas. Pamatnostādnes atzìst arī to, ka atbildība sociālo pakalpojumu plānošanā, sniegšanā un uzraudzībā ir sadalìta starp valsti un pašvaldībām, kaut arī komunikācija starp dažādiem pārvaldes līmen̦iem pieklibo. «Iekḷaujošas nodarbinātỉbas pamatnostādnes 2015.-2020. gadam» ietver teorētiski pareizu, bet grūti realizējamu principu - nodrošināt efektīvu darba tirgus un sociālās aizsardzības sistēmu pārvaldību, ietverot politiku īstenošanas monitoringu, analīzi un rezultātu novērtēšanu.

Lai arī pamatnostādṇu aprakstošajā daḷā ir ietverts vairāk vai mazāk detalizēts skaidrojums un nākotnes redzējums, nonākot līdz rezultatīvo rādītāju sadalaiai, nākotnes redzējums pazūd ḷoti fragmentētos rezultatīvajos rādītājos, ar kuru palīdzību būtu jāveic monitorings un uzraudzība. Diemžèel ari šìs jomas pamatnostādnes nespēj pèc diviem trim svarịgākajiem rādìtājiem prognozēt, kāda būs šìs jomas politika pēc septiniiem gadiem. Parasti pamatnostādnēs progress tiek mērìts ar rezultatīvajiem rādītājiem, kas ir vērsti uz administratìvo pūlu un resursu novērtēšanu, tomēr galu galā ir grūti pateikt, kāda ir bijusi pievienotā vērtība no attiecīgā dokumenta. Šajā kontekstā ir jāuzsver arī tāds iestāžu rīcības formulējums kā «izvērtēt iespēju» vai «ieviest iespēju», kas drīzāk liecina par kopēju sistēmas maldīšanos, jo šādi uzdevumi būtu jāveic attiecīgās rīcībpolitikas izstrādes posmā, nevis tad, kad jau ir izstrādātas pamatnostādnes, kuras pieprasa noteiktu darbošanos.

Pārvaldība sociālajā jomā: sociālo darbinieku skatījums
Sociālie darbinieki un sociālās jomas profesionāli ievieš izstrādātās rīcībpolitikas, tādēl vinu skatījums un viedoklis var
1. tabula. Sociālās jomas darbinieku attieksme pret darbu $(n=66)$

\begin{tabular}{|c|c|c|c|}
\hline Darba apstākḷi & Apgalvojums & Latvija & Lietuva \\
\hline \multirow[t]{6}{*}{$\begin{array}{l}\text { Normativais } \\
\text { rāmis }\end{array}$} & $\begin{array}{l}\text { Manam rīcības plānam un rīcībai, veicot } \\
\text { pienākumus, ir jābūt racionāliem un jābalstās } \\
\text { uz vienlīdzīgu attieksmi pret visiem }\end{array}$ & 67,7 & 81,8 \\
\hline & Man ir jāciena mana darba profesionālās vērtības & 78,2 & 77,7 \\
\hline & $\begin{array}{l}\text { Likuma varas cienīšana ir katra indivìda } \\
\text { pienākums sabiedrībā }\end{array}$ & 66,4 & 77,4 \\
\hline & $\begin{array}{l}\text { Es jūtu līdzi cilvēkiem, kas atrodas grūtā situācijā, } \\
\text { un tāpēc cenšos darìt visu, lai palīdzētu klientiem }\end{array}$ & 71,2 & 62,8 \\
\hline & $\begin{array}{l}\text { Man ir jāciena sabiedrības viedoklis, definējot un } \\
\text { nosakot, kādus pakalpojumus sniegt }\end{array}$ & 63,7 & 69,9 \\
\hline & $\begin{array}{l}\text { Man ir būtisks tas, ka es varu piedalīties labākas } \\
\text { sabiedrības veidošanā }\end{array}$ & 67,7 & 78,2 \\
\hline \multirow{3}{*}{$\begin{array}{l}\text { Attiecības } \\
\text { darbavietā }\end{array}$} & Man ir jāsaglabā labas attiecības ar kolēgiem & 65,7 & 66,6 \\
\hline & $\begin{array}{l}\text { Man ir jāprot ilgstoši sadarboties un saglabāt } \\
\text { labas attiecības ar citām iestādēm }\end{array}$ & 71,9 & 64,0 \\
\hline & $\begin{array}{l}\text { Es varu tikt sodìts par nepareizu lēmumu } \\
\text { pieṇemšanu }\end{array}$ & 61,1 & 39,7 \\
\hline $\begin{array}{l}\text { Ekonomiskie } \\
\text { ierobežojumi }\end{array}$ & $\begin{array}{l}\text { Man ir jārīkojas tā budžeta ietvaros, kas ir } \\
\text { pieejams iestādei }\end{array}$ & 68,0 & 54,8 \\
\hline $\begin{array}{l}\text { Administrativie } \\
\text { ierobežojumi }\end{array}$ & $\begin{array}{l}\text { Man ir jāsamierinās ar manas iestādes } \\
\text { administratīvo kapacitāti paveikt visus tai } \\
\text { uzdotos uzdevumus }\end{array}$ & 68,0 & 78,9 \\
\hline
\end{tabular}

Piezīme: vērtējumi, kas ir augstāki par 50, rāda, ka respondenti piekrit apgalvojumam. Savukārt vērtējumi zem 50 rāda, ka respondenti nepiekrit vērtējumam. Izmantots Kraskola-Valisa (Kruskal-Wallis) tests, lai salīdzinātu dažādas grupas. (Kjorstad, Tufte, \& Koht, 2014) 
atklāt tendences, kuras ir būtiskas, lai nodrošinātu sekmīgu $\quad 4$ Intervijas sākotnēji tika rīcībpolitikas ieviešanu. Uzreiz pēc krīzes, 2010.-2012. gadā, veiktas NOBA projekta Latvijā un Lietuvā tika veiktas intervijas ar sociālās jomas $\quad \begin{aligned} & \text { ietvaros 2010.-2012.gadā. } \\ & \text { Intervijas Latvijā veica }\end{aligned}$ darbiniekiem, lai izprastu krīzes ietekmi no rīcībpolitikas Iveta Reinholde, bet Lieieviesēju skatỉjuma un salīdzinātu situāciju divās kaimiṇval- tuvā-Dangis Gudelis un stīs. Intervijās ${ }^{4}$ izkristalizêjās vispārējā tendence, ka sociālajā Vida Lukamskiene. Kopējo jomā strādājošie pozitivi vērtē vadības sistēmu, kas ir izvei- interviju skaits Latvijā-39,

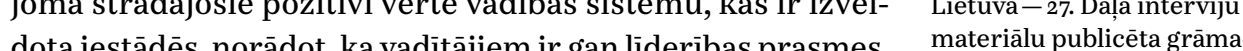
gan arī kompetence. Turklāt sociālo darbinieku skatijumā ie- tā: Kjorstad, M., \& Tufte, C.G. stāžu vadītāji pamazām papildina pakalpojumu standartus ar (2014). Challengesfrom an praktiskas darbibas piemēriem. Šāda nostādne atbilst Eiro- professionalism and pracpas vispārējās nozīmes pakalpojumu nosacijumiem par to, ka tical ethis in carefor older pakalpojuma saṇemšanas standarti ir būtiski pakalpojuma and Norway. Rigga: Zinātne. izaugsmes mērī̌sanai. Kāds sociālās jomas darbinieks norā- kā ari šis grămatas rakstā dỉja: «Vadībai ir būtiska loma sociālo pakalpojumu kvalitātes Reinholde, I. (2014).Adminis un efektivitātes noteikšanā. Tieši sociālās politikas attīstība tration of Local Servicesfor

pratnes.» Turklāt sociālās jomas darbinieki jo ỉpaši uzsvēra

komandas darbu kā vienu no lielākajām profesionālajām vērtībām gan sociālajos dienestos, gan sadarbībā ar citām institūcijām.

Viens no galvenajiem pārvaldības sistēmas elementiem ir normatīvu kopums, pēc kura organizācijas un indivīdi strādā. Kopumā Latvijas sociālās jomas darbinieki respektē valstī iedibināto normatīvo kārtību un izprot to, ka vinu darbošanās notiek saskanāa ar normatīviem. Lỉdzịga situācija ir arī Lietuvā - tas apliecina, ka abas valstis ir lỉdzịgā attīstības stadijā. Latvijas sociālie darbinieki ne tikai atbalsta likuma varu un profesionālās vērtỉbas, bet arī atzīst misijas apziṇas lomu, palīdzot klientiem. Savukārt attiecības darbavietā vairs nav tik vienkāršas. Latvijā sociālās jomas darbinieki daudz vairāk salïdzinājumā ar Lietuvas kolēgiiem raizējas par to, ka nepareiza lēmuma gadījumā viṇi tiks sodīti. Tajā pašā laikā, salīdzinot abas valstis, var konstatēt arī to, ka Lietuvas kolēǵiem sava rīcība un rīcỉbas plāni ir jāizstrādā detalizētāk un pamatotāk nekā Latvijas kolēǵiem. Tas l̦auj secināt, ka droši vien Latvijas sociālās jomas darbiniekiem bieži vien ir mazāk laika, ko veltìt darbu plānošanai un ieviešanai, līdz ar to palielinās bailes, ka nepareiza rīcība tiks sodìta. Turklāt bailes par sodu, visticamāk, nav tikai pienēmumi, bet gan pieredze.

Neapšaubāmi, gan Latvijas, gan Lietuvas sociālās jomas darbinieki lielākoties piekrīt tam, ka vadības kultūra un kopigas vērtïbas ir svarīgas, lai sasniegtu ne tikai iestādes mērkus, bet arì rīcibpolitikas mērkłus.

Lai arī kopumā atškiirības starp vērtējumiem nav lielas, ḷaujot secināt, ka kopumā Latvijā un Lietuvā sociālās jomas darbinieki domā līdzịgi, tomēr ir vêrts norādīt uz dažām interesantām niansēm, kas lautu detalizētāk saprast tieši Latvijas situāciju. Pirmkārt, neapšaubāmi ir jāievēro Latvijas
2. tabula. Darbinieku vērtējums par vadības sistēmu iestādē $(n=66)$

\begin{tabular}{|c|c|c|c|}
\hline Darba apstākḷi & Apgalvojums & Latvija & Lietuva \\
\hline \multirow{8}{*}{$\begin{array}{l}\text { Vadības } \\
\text { kvalitāte }\end{array}$} & Es ticu savai iestādei & 77,4 & $76, c$ \\
\hline & $\begin{array}{l}\text { Man un manam vadītājam ir kopīga izpratne par to, } \\
\text { kas ir «labi paveikts» darbs mūsu jomā }\end{array}$ & 71,6 & 66,6 \\
\hline & Manas iestādes darbinieki sadarbojas, lai paveiktu darbu & 77,5 & 76,4 \\
\hline & $\begin{array}{l}\text { Maniem kolēǵgiem ir nepieciešamās prasmes un } \\
\text { iemaņas darbu veikšanai }\end{array}$ & 72,7 & 73,1 \\
\hline & Mana vadība ir atradusi kopigu valodu ar darbiniekiem & 76,0 & 81,4 \\
\hline & Mans vadītājs rūpigi izvērtē manu darbu & 70,0 & 65,1 \\
\hline & $\begin{array}{l}\text { Iestādē ierosinātās disciplinārpārbaudes ir taisnīgas } \\
\text { un pamatotas }\end{array}$ & 69,2 & 61,6 \\
\hline & Man ir diezgan liela rīcības brīvība manā darbavietā & 72,2 & 66,6 \\
\hline \multirow[t]{5}{*}{$\begin{array}{l}\text { Apmierinātība } \\
\text { ar darbu }\end{array}$} & $\begin{array}{l}\text { Savā darbā es jūtu, ka esmu paveicis kaut ko } \\
\text { patiešām vērtīgu }\end{array}$ & 74,8 & 74,7 \\
\hline & $\begin{array}{l}\text { Nav lielu iespēju mainìt situāciju šajā vietā } \\
\text { (novadā, reĝionā) }\end{array}$ & 63,3 & 41,5 \\
\hline & Mani darba pienākumi ir izaicinājumu pilni & 55,8 & 57,6 \\
\hline & Kopumā man patīk darbs, ko daru & 74,4 & 73,6 \\
\hline & Es smagi strādāju, veicot savus pienākumus & 69,6 & $47, \mathrm{C}$ \\
\hline $\begin{array}{l}\text { Ekonomiskie } \\
\text { labumi }\end{array}$ & $\begin{array}{l}\text { Esmu apmierināts ar to algu, ko saṇemu, zinot, } \\
\text { ko cilvēki saṇem par līdzīgu darbu valsts pārvaldē }\end{array}$ & 71,8 & 37,4 \\
\hline
\end{tabular}

Piezīme: vērtējumi, kas ir augstāki par 5o, rāda, ka respondenti piekrit apgalvojumam. Savukārt vērtējumi zem 50 rāda, ka respondenti nepiekrìt vērtējumam. Izmantots (Kjorstad, Tufte, \& 
sociālās jomas darbinieku salīdzinoši lielā apmierinātība ar atalgojumu. Lai arī Lietuvas kolēǵi ir neapmierināti un pat sliecas uzskatît, ka viṇu atalgojums nav konkurētspējiğss, Latvijā situācija ir pretēja. Tiesa, šie dati tika iegūti 2010. gadā burtiski pēc krīzes, un tas lauj secināt, ka tajā mirklī bija daudz svarīgāk būt nodarbinātam, kad kopumā valstī ir ārkārtīgi liels bezdarbs.

No vadības perspektīvas situāciju sociālajā jomā var raksturot ḷoti vienkārši. Sociālās jomas darbinieku skatījumā darbs ir izaicinājumu pilns, tajā var paveikt sabiedrībai būtiskas lietas, lai arī ir jāstrādā smagi. Turklāt Latvijā sociālās jomas darbinieki labi saprotas gan ar kolẹógiem, gan ar vadību un tiem ir diezgan liela rīcibas brīiviba, pildot savus pienākumus. Grūtāk ir izskaidrot to, ka Lietuvas kolēğu skatījums ir pesimistiskāks, jo Lietuvas kolēǵi tomēr nav apmierināti ar atalgojumu, viṇos valda zināma bezspēcība, jo nav iespējams mainìt situāciju valstī. Lietuvā sociālās jomas darbinieku rīcības brīìiba ir ierobežotāka.

Sociālās jomas darbinieku viedoklis ieskicē pārvaldỉbas sistēmas vājos punktus - darbinieku bailes no soda par pārkāpumu, bet visas iespējamās situācijas sociālajā jomā nav iespējams uzmodelēt un paredzēt normatīvajos aktos, jo sevišķi krīzes situācijas. Faktiski tas ir jautājums par sociālās jomas darbinieku minimālās rīcības brīiibas ațlaušanu, lai sasniegtu svarīgāko mērḳi-sniegt palīdzību personai, kura ir krīzes situācijā, nevis mēógināt visas iespējamās problēmas ietērpt normatīvo aktu lỉkločos. Tā kā situācija pasaulē strauji mainās un parādās arvien vairāk kompleksu problēmu, turpmāk sociālās politikas veidotājiem un ieviesējiem arvien vairāk būs jābūt gataviem meklēt starpinstitucionālus risinājumus.

\section{Secinājumi}

Kopumā jāsecina, ka sociālās politikas jomā, tāpat kā citos sektoros, pastāv vairāki rīcībpolitikas plānošanas dokumenti, kur katrs koncentrējas uz noteiktu un specifisku problēmu risināšanu. Vienlaikus ir manāmas grūtības šos dokumentus harmoniski ieviest, un beigās ir pat jākonstatē, ka plānotie rezultāti nav sasniedzami. Līdz ar to politikas plānotājiem nākas gan radoši taisnoties, kādēḷ nav sasniegti pašu dokumentos ierakstîtie rezultāti, gan arī meklēt idejas, kā sabiedrībai un politiḳiem izskaidrot, kāpēc plānotās rīcības nav veiktas vai arì ir nesušas gluži citas sekas. Tādēl skaidrs mērka definējums, plašas diskusijas ar sabiedrību, ko vēlamies sasniegt kā sociāli atbildīga valsts, un apṇemšanās ieviest visaptverošo rīcibpolitiku pieeju ir svarīgi soḷi ceḷā uz pārmaiṇām.

Apskatītajos rīcībpolitikas plānošanas dokumentos var identificēt vēl vienu tendenci, kas jau ir nostiprinājusies Latvijas rīcībpolitikas plānošanas praksē,-koncentrēšanos uz attiecīgās politikas jomu, minimāli aplūkojot vai nemaz neapskatot rīcỉbpolitiku mijiedarbỉbu un mijiedarbïbas sekas.
Tas, savukārt, ietver risku, ka labiem nodomiem vienā rīcībpolitikas jomā var būt negatīvas sekas citā jomā.

Vienlaikus, skatoties no rīcibpolitiku ieviešanas perspektīvas, var secināt, ka sociālās jomas darbinieki gan izprot normatīvo nosacỉjumu iespējas un ierobežojumus, gan arī bažìjas par sodu nepareiza lēmuma gadỉjumā. Tik mainīgā un izaicinājumu pilnā politikas jomā kā sociālā politika dažkārt ir grūti noteikt robežu starp pareizu un nepareizu lēmumu, jo katrs lēmums ir saistìts ar indivìdu un drīzāk jāvērtē kā atbilstošs vai neatbilstošs attiecīgajai situācijai.

\section{Izmantotie avoti}

BBC (2009, 09 Oct.). Latvia to find more budget cuts. Retrieved from http://news.bbc. co.uk/2/hi/business/8298272.stm

CEEP (2010). Public services in the European Union \& in the 27 member states. Statistics, organisation and regulations.

Commission of the European Communities (2006). Communication from the Commission - Implementing the Community Lisbon programme - Social services of general interest in the European Union $\{\operatorname{SEC}(2006) 516\} / *$ COM/2006/o177 final. Retrieved from http://eur-lex.europa.eu/LexUriServ/ LexUriServ.do?uri=COM:2006:0177:FIN:EN:HTML

Commission of the European Communities (2007). Communication from the Commission to the European Parliament, the Council, the European Economic and Social Committee and the Committee of the Regions accompanying the Communication on «A single market for 21st century Europe»-Services of general interest, including social services of general interest: a new European commitment \{COM(2007) 724 final\} \{SEC(2007) 1514\} \{SEC(2007) $1515\}\{\operatorname{SEC}(2007) 1516\} /$ COM/2007/0725 final. Retrieved from http://eur-lex. europa.eu/LexUriServ/LexUriServ.do?uri=COM:2007:0725:FIN:EN:html

European Commision (2004). Communication from the Commission to the European parliament, the Council, The European Economic and Social Committee and the Committee of Regions. White Paper on services of general interest. Brussels, 12.5.2004., СOM(2004) 374 final.

European Commission (2012). Smart regulation-Questions and Answers. Retrieved from http://europa.eu/rapid/press-release_MEMO-12-974_en.htm

European Parliament (2010). The interrelationship between the structural funds and the provision of services of general (economic) interests and the potential for cross-border service delivery, p.14.

Finanšu ministrija (2008). Nodomu protokols Starptautiskajam Valūtas fondam 2008. gada 18. decembrī. Izgūts no http://www.fm.gov.lv/files/files/Nodomu vestule_SVF_2008-12-18.pdf 
Finanšu ministrija (2009a). Latvija: Nodomu protokols Starptautiskajam Valūtas fondam 2009. gada 27.jūlijā. 5.lpp. Izgūts no http://www.fm.gov.lv/files/files/ Nodomu_vestule_SVF_2 julijs_2009.pdf

Finanšu ministrija (2009b). Saprašanās memorands starp Eiropas kopienu un

Latvijas Republiku. 28.01.2009., 2.-3.lpp. Izgūts no http://www.fm.gov.lv/files/ files/MoU_LV_tulkojums.pdf

Finanšu ministrija (2010). Latvija: Nodomu vēstule. Rīgā, 05.07.2010., 4.lpp. Izgūts no http://www.fm.gov.lv/files/files/Nodomu_vestule_SVF_2010-07-05.pdf

Finanšu ministrija (2011). Latvija: Nodomu vēstule. Rīgā, o9.05.2011., 5.lpp. Izgūts no http://www.fm.gov.lv/files/files/Nodomu_vestule_SVF_2011-06-08.pdf

Green Paper on Services of General Interest (2003). Brussels, 21.05.2003., COM(2003) 270 final.

Kjorstad, M., Tufte, C. G., \& Koht, H. (2014). Deciding Individual Cases in Care for Older People - the Vignette Study. In M. Kjorstad, C. G. Tufte, Challenges from an ageing population: Legality, professionalism and practical ethis in care for older people in Latvia, Lithuania, and Norway. Rīga: Zinātne.

Latvijā augstākais bezdarba līmenis ES (2017). Izgūts no http://www.ekonomika.lv/ latvija-augstakais-bezdarba-limenis-es/

Ministru kabinets (2008). Ekonomikas stabilizācijas un ekonomikas izaugsmes atjaunošanas programma. Apstiprināta Ministru kabinetā 09.12.2008. Izgūts no http://www.mk.gov.lv/lv/mk/tap/?pid=40102497\&mode $=$ mk\&date $=2008$ 12-09

Ministru kabinets (2009, 16. apr.). Ministru kabineta noteikumi Nr. 300 «Ministru kabineta kārtỉbas rullis». Pieṇemts 07.04.2009. Latvijas Vēstnesis, 28. 3. pielikums, 2.1. punkts.

Moors, M. (2007) Sociālā darbinieka profesionālās identitātes veidošanās problēmas. Sociālais darbinieks, 2(23), 10.-13.lpp. Izgūts no http://www. socialwork.lv/resursi/materiali/sd-biedribas-raksti/197-sd-prof-identitatesveosanas-problemas

Osborne, S. P. (2010). The New Public Governance?: Emerging Perspectives on the Theory and Practice of Public Governance. Routhledge.

Pārresoru koordinācijas centrs (2012). Latvijas Nacionālais attīstības plāns 2014.2020. gadam. Apstiprināts ar Latvijas Republikas Saeimas lēmumu 20.12.2012. Izgūts no http://www.pkc.gov.lv/images/NAP2O2O dokumenti/20121220_ NAP2O2O apstiprinats Saeima.pdf

Reğionālās attisstỉbas un pašvaldỉbu lietu ministrija (2006). Latvijas Nacionālais attīstības plāns 2007-2013. Latvijas Republikas Reğionālās attīstïbas un pašvaldibu lietu ministrija. Izgūts no http://www.innovation.lv/wp-content/ uploads/2013/10/Latvijas_Nacionalais_attistibas_plans_2007-2013.pdf

Reinholde, I. (2012). Cilvēkdrošǐba iekšpolitikā: vispārējās nozīmes pakalpojumi kā cilvēkdrošibas indikators. No Ž. Ozolina (red.), Cilvēkdrošǐba Latvijā un pasaulē: No idejas līdz praksei. Rỉga: Zinātne.
Reinholde, I. (2013). Pārvaldïba: laba vai vieda? Latvijas intereses Eiropas Savienībā, 4, 22.-27.lpp.

Saeima (2002, 19. nov.). Sociālo pakalpojumu un sociālās palīizzỉbas likums. Pienemts 31.10.2002. Latvijas Vēstnesis, 168. Izgūts no http://www.likumi.lv/ doc.php?id $=68488$

Valsts kanceleja (2006) ES fondu vārdnīca. Izgūts no http://mk.gov.lv/lv/ esstrukturfondi/atbildigaiestade/resursi/es-fondu-vardnica/

Walsh, M., Stephens, M., \& Moore, S. (2000). Social Policy and Welfare. Nelson Thornes.

World Health Organization (2011). Governance for health in the 21st century: a study conducted for the wHO Regional Office for Europe. EUR/RC61/Inf. Doc./6. 18 August. Retrieved from http://www.euro.who.int/_data/assets/ pdf_file/o010/148951/RC61_InfDoc6.pdf 


\section{Veselības stāvokḷa nevienlīdzība un veselības rīcỉbpolitika Latvijā}

Mūsdienās līdz ar zinātnu attīstību cilvēka mūža ilgums pieaug. Līdztekus pozitīvām tendencēm rodas jauni un klūst aktuāli citi veselības jomas jautājumi, piemēram, veselības stāvokḷa nevienlīdzība. Turklāt var pieṇemt, ka attīstība vienlaikus var pastiprināt negativvas tendences. Piemēram, tiek uzskatìts, ka sabiedrības attīstība var radìt nevienlīdzîbas pieauguma iespējamību, jo sabiedrỉbas attīstỉba ir priekšnoteikums nevienlīdzỉbas apstākliiem. Veselības stāvoklis un veselïbas stāvokḷa nevienlídzība ir daudzdimensionāli fenomeni, jo tie ietekmē daudzus aspektus un tos ietekmē daudzi aspekti. Tie var ietekmēt kā sociālos, tā ekonomiskos procesus, un dažādi sociālie un ekonomiskie faktori var būt priekšnoteikumi veselības stāvoklim un veselïbas stāvokḷa nevienlīdzỉbai.

Pētijumi par sociālekonomiskās labklājỉbas ietekmi uz veselības stāvokli ir būtiski rīcībpolitikas îstenotājiem valstīs, kur pastāv demogrāfiskie apstākḷi, kas negatīvi ietekmē ekonomisko attīstību dažādās jomās, un kur ir ierobežoti resursi un kritiska situācija, nodrošinot ar veselību saistìtos labumus ar pašreizējiem veselības aprūpes resursiem (Fotso \& Kuate-Defo, 2005). Veselības stāvokḷ sociālekonomiskā nevienlīdzība pastāv lielākajā dalā pasaules reǵionu, kaut arī ir vērojami tirgus uzlabojumi attiecībā uz veselību un dzives standartiem (OECD, 2008). «Tiesības uz veselību ir viena no cilvēka pamattiesībām. Arī Latvijas Republikas Satversmes 111. pantā ir noteikts, ka «valsts aizsargā cilvēku veselïbu». Eiropas Kopienas dibināšanas līguma 152. pantā teikts, ka «nosakot un īstenojot visu Kopienas politiku un darbības, ir jānodrošina augsts cilvēku veselības aizsardzības līmenis».» (Ministru kabinets, 2014)

Mūsdienās ir mainījušās pieejas rīcībpolitikas veidošanai gan veselỉbas, gan citās rīcībpolitikās. Sabiedrība arvien vairāk uzmanības pievērš labas un viedas pārvaldïbas principiem, rīcibpolitiku pamatotỉbai, skaidriem rīcībpolitiku ietekmes novērtējumiem, un aizvien biežāk daudzi jautājumi tiek identificēti kā piederīgi starpsektoru rīcībpolitikai. Arī veselības stāvoklis tā daudzdimensionālās dabas dēḷ paredz rīcībpolitiku starpsektoru pieeju un starpdisciplinaritāti šì jautājuma pētniecībā.

Veselïbas jautājumu aktualitāti Latvijā apstiprina statistika, kur Latvijas veselības aprūpes sistēmai ir viens no sliktākajiem novērtējumiem Eiropā, vidējais paredzamais mūža ilgums ir 72,2 gadi, kas ir otrs zemākais Eiropas Savienībā. Latvijā sabiedrība saskaras ar nopietnām veselības problēmām, piemēram, ir augssta saslimstība ar HIV, alkohola patēriṇš un viens no augstākajiem pašnāvību rādītājiem pasaulē (EuroHealthNet, n. d.), vieni no augstākajiem mirstības rādìtājiem Eiropā, paredzamais mūža ilgums ir zemāks nekā vidējais ES, vairāk nekā 10\% iedzìvotāju savu veselību vērtē kā sliktu vai loti sliktu, ir viena no lielākajām zīdainu mirstības proporcijām pret jaundzimušo skaitu, viens no augstākajiem smēḳējošo jauniešu rādītājiem ES (European Commission, 2013). Taču statistika liecina arī par jautājuma 
daudzdimensionalitāti, jo, kontrolējot citus mainīgos, var konstatēt, ka pastāv atšķiriibas starp sociālekonomisko mainīgo grupām un veselỉbas stāvokli raksturojošo statistiku (Monden, 2004; European Commission, 2013).

Sistemātiskai veselības stāvokḷa nevienlīdzības un veselības rīciibpolitiku izpētei ir formulēti trīs pētnieciskie jautājumi: 1) kāda veselības stāvokḷa nevienlīdzība pastāv Latvijā starp iedzìvotājiem (iekḷauto demogrāifisko mainigo kontekstā); 2) kāds ir visbūtiskākais sociālekonomiskais faktors veselības stāvokla nevienlïdzībai Latvijā (rada iespēju identificēt būtiskākos un mazāk būtiskos sociālekonomiskos faktorus); 3) vai Latvijas Republikas Veselības ministrijas rīcībpolitikas ir saskaṇā ar konstatētajām veselības stāvokla nevienlïdzības tendencēm Latvijāa (nodrošina savstarpējās salīdzināšanas iespējas starp aptaujas analīzes rezultātiem un rīcībpolitikas dokumentiem). Formulētie jautājumi, runājot par veselības stāvokli, saskan ar izvirzìto izpētes mērki: izprast un analizēt, pirmkārt, kāda veida nevienlīdzība pastāv Latvijā, otrkārt, kādiem faktoriem ir vislielākā ietekme, un, treškārt, sniegt analïtisku vērtējumu par provizoriskajām rīcībpolitikām un lēmumiem. Pētijjums veikts vairākās daḷās atbilstoši izvirzìtajam mērḳim un izpētes jautājumiem.

Šajā nodaḷā uzmanība vērsta uz individuālā veselības stāvokḷa pašnovērtējuma izpēti, izlases reprezentativitātes dēḷ rezultātus attiecinot uz Latvijas sabiedrību. Pētīta arī veselības rīcībpolitika, identificējot kopỉgo un atšḳirīgo starp formulētajām rīcībpolitikām un veselības stāvokḷa pašnovērtējumu. Lìdzịgu pētijuma ideju pamatā ir indivĩdu veselības stāvokl̦a identificēšana un esošo vai bijušo atšķirīibu noteikšana starp dažādiem sociālekonomiskajiem mainīgajiem (Fuchs, 2004). Taču pamata grūtỉbas rīcībpolitikās rodas jautājumā par to, kā ietekmēt noteikto indivīdu grupu, novēršot veselības stāvokḷa riskus. Veselības stāvokḷa nevienlīdzìba nav fiksēta situācija, to ietekmēe dažādas atškirības starp indivīdiem, un tā mainās, mainoties laikam (Brownson et al., 2004, p. 184). Tādēḷ arī ir nepieciešama elastīga rīcibpolitiku reakcija.
Veselības stāvok!̣a pašnovērtējums, veselības stāvoklis, tā nevienlīdzība un veselību ietekmējošie faktori

Veselības stāvoklis var tikt uztverts arì kā sociālo zinātṇu priekšmets vairāku iemeslu dēl. Indivìdu sociālo un ekonomisko apstākḷu atšḳirības ietekmē veselības stāvokli. Evidences* norāda uz to, ka medicīna vairs nav spējiga pilnvērtīgi skaidrot veselības stāvokli un veselības stāvokḷa problemātiku, jo vairākas veselības problēmas ir saistītas ar sociālajiem un ekonomiskajiem apstākḷiem un priekšnoteikumiem. Sociālo zinātṇu pētỉjumos par veselības stāvokḷa nevienlīdzību tiek meklēti iemesli tam, kādēẹ viens indivìds vai sabiedrības daḷa ir veselāka par otru, kā
* Tiek nošķirti jēdzieni «evidence» (no anglu val. evidence) un therdijumse (no anglu val prob). Evidences ir fakti, liecinäjumi, kas atspogulo pienozimēe, ka pienēēmuma atbilstiba patiesibai ir pamatota. Pierădijums ir pamatojums, kas norāda uz kaut kā atbilstīibu patiesỉbai, un pierādišanas veids, kad tiek pārbaudita pienēēmuma atbilstiba patiesibai. Pierādijums ietver evidenču un citu pamatojumu izmantošanu, apstiprinot kaut kā patiesumu (McKeown, 2014). Pierādijums nozīmē, ka pieñēmums ir patiess. Evidences variē atkarỉbă no patiesibas izpratnes un atkarỉbā no konkrētās jomas zināšanu attistibas pakāpes. Evidencēm ir divas izpratnes: 1) evidenceem ir jabut saskaṇā ar noteiktiem zinătniskiem priekšstatiem un konstrukcijām, 2) ikviens novêrojums par noteikto jautājumu var tikt uzskatits par evidenci. Evidence vairākumā gadijumu ir neatkarīgs un pārbaudām novêrojums ar pärliecinošu saturu, pretêjā gadìjumã tă ir interpretăcija (Nutley, Davies, \& Smith, 2000). Evidence pamato, un pierādijums apliecina to, vai izteiksme ir vai nav pierādita (Twining, 1985). Evidences pilda atbalsta funkciju t. s. rīcibpolitikās. Evidences ir bütiskas vairäkos rīcibpolitikas aspe tos, t. sk. nodrošinot cilvēku vēlmju un vajad

atspoguḷojumu (King's College London, n. d.).

Pastâv divas evidenču perspektivas: objektivā un ricibibpolitikām (Killoran \& Kelly, 2010, p.148). nèmuma patiesumu (Best, 2009, p. 105). Evidence
Objektivā evidence ir atkārtoti pārbaudāma un nav ietekmēta no personas pieredzes vai priekšstatiem, tā izriet no faktiem vai matemātiskām katkulācijām. Subjektivā evidence ne vienmēr ir atkārtoti pārbaudāma, jo ietver arì personas objektîvo pieredzi vai priekšstatus, tā ir saistita ar objektiviem pamatiem realitātē un atspogulo arì personas realitātes redzējumu (Achinstein, 2005). ties, kur zināšanu, izpratnes un evidenču esamïba nosaka părvaldibas pamatotibu. Ja netiek ievēroti sie priekšnoteikumi, tad parvaldiba nav vêrsta uz ilgtspējigu attisstibu un cilvēku dzives kvalitāti, kas var büt pretrunā visparrejâs attistibas principiem un pretrună sabiedribas vềmèm un vajadzibām. amatotibu un uz zinãšanām balstitu speju rikoes skaidro uz evidencem balstitas ricibpolitikas pieeja. Pieeja nodrošina izpratni par rīcibpolitikas vidi un tās izmaināanm; palìdz izvềrtēt iespējamo ricibpolitiku ietekmi, nodrošinot labākās rīcibpotikas strategijas izveles iespejas, saskanaa ar parestarp stratêǵgiskās darbỉbas virzienu un paredzamajiem rezultātiem, ricībpolitikas mērḳiem, kas nodrošina skaidru argumentāciju; nosaka to, kas ir jādara, lai sasniegtu rīcibpolitiku stratếgís kos mērķus vai starprezultātus; ietekmē citus, iesaistot mèr,ạa sasniegšanā, nodrošna kvalitativu komunikāciju (Shaxson, 2005); palìdz pieṇem Pārvaldība ir uz zināšanām balstita spēja rikkozamajām sekām un rezultātiem; atspogulo saikn

iespējams uzlabot veselības stāvokli vai samazināt tā nevienlīdzỉbu. Pētniecības rezultātā tiek iegūtas zināšanas par veselïbas stāvokḷa problēmu un tā nevienlīdzības sociālajiem iemesliem. Būtiskākais sociālo zinātṇu pètỉjumos ir mēǵinājums skaidrot, kā sociālie un ekonomiskie procesi ietekmē veselības stāvokli. Viena no pieejām veselības stāvokḷa izpētē paredz atteikties no formālām diagnozēm un pievērsties veselības stāvokla evidences subjektīvajai perspektīvai. Ar veselības stāvokḷa evidences subjektīvo perspektīvu šajā pētỉjumā tiek saprasts veselības stāvokḷa pašnovērtējums.

Veselības stāvokḷa pašnovērtējuma pētniecības būtiskumu apstiprina vairāki argumenti. Veselības stāvokḷa pašnovērtējums var būt kā mainịgais, prognozējot un nosakot cilvēku veselības aprūpes sistēmas iespēju izmantošanu, mirstību un citus būtiskus mainīgos (DeSalvo et al., 2005). Veselības stāvokla pašnovērtējums ietver visus aspektus, kas raksturo veselības stāvokli, atškirīibā no daudziem objektīvajiem mainīgajiem, piemēram, mirstības rādītāji neatspoguḷo veselības stāvokḷa aspektus, kas nerada letālas sekas. Tāpa subjektīvā pašsajūta ietekmē veselības stāvokli, arī daudzos medicinisk rakstura pētijumos ir pierādīts, ka subjektīvā uztvere ietekmē objektīvos ar 
veselības stāvokli saistitos fizioloğiskos procesus. Vairāki pētijumi atspogulo, ka veselības stāvokḷa pašnovērtējums norāda uz veselïbas problēmām, ir mirstības paredzēšanas mainigais (Ginzler, 2010) un tiek klasificēts kā «spēcīgā̀) evidence (Fayers \& Hays, 2005, p. 314; McFadden et al., 2008). Vairāki pētỉjumi arī apstiprina, ka veselības stāvokḷa pašnovērtējumam ir tikpat nozimīga ietekme uz veselību un ar veselību saistītu uzvedību kā objektīvajiem mainiggajiem, taču šì ietekme nereti var būt atšķirìga, piemēram, negatìva iepretī pozitivai (Mossey \& Shapiro, 1982).

Veselības stāvoklis ir slimỉbas un vājuma neesamība, kā arī pilnīgs mentālās un fiziskās labklājības stāvoklis (World Health Organization, 1946). Veselības stāvokli ietekmē daudzi faktori: vecums, dzimums, iedzimtie faktori, individuālie dzives jeb individuālās uzvedības faktori, sociālie un kopienas tìklu faktori, strukturālie faktori, sociālekonomiskie, kultūras un vides apstākḷi (Eyal et al., 2013, p. 6). Šo faktoru atšǩirības starp individdiem rada veselïbas stāvokla nevienlïdzỉbu. Veselïbas stāvokla nevienlïdzìba atspogulo veselības statusa variācijas individuālā, reğionālā vai citā lìmenī. Veselības stāvokḷa nevienlīdzības jēdziens tiek izmantots, lai atspoguḷotu veselības statusa atškirības starp individiem vai grupām (Kawachi, Subramanian, \& Almeida-Filho, 2002). Jēdziens «veselības stāvoklis» ir plašs, to ir grūti operacionalizēt, nosakot laba un slikta veselības stāvokḷa robežškirintni.

Šajā pētījumā jēdziens «veselības stāvokla nevienlīdzỉba» lietots divu pamata iemeslu dēḷ. Pirmkārt, tas risina operacionalizācijas ierobežojumus. Citiem vārdiem sakot, ir sarežǵîiti identificēt, kas ir veselība, laba vai slikta veselība izmērāmās indikācijās, taču ir vienkāršāk, savstarpēji salīdzinot, identificēt, kas ir labāks vai sliktāks veselības stāvoklis. Otrkārt, tiek lietoti dažādi jēdzieni, piemēram, «veselības stāvokḷa atšķiirības» (Braveman, 2006), «veselības stāvokḷa variācijas», taču jēdziens «veselības stāvokḷ nevienlïdziba» ietver sociālo un ekonomisko nevienlïdzỉbu, ar kuru šìs veselības stāvokḷa atšḳiriibas ir saistîtas (Graham, 2009), un iekḷauj arī ietekmējošo faktoru izpratni. Veselības stāvokḷa nevienlīdzības jēdziens visbiežāk tiek lietots, lai aprakstītu sakarību, kur indivìdu sociālās un ekonomiskās atškirības saistītas ar vinu veselības stāvokla atškirībām (Andresen \& DeFries Bouldin, 2010).

Rīcībpolitikām būtiski ir ne tikai noskaidrot, vai un kāda veselïbas stāvokla nevienlīdzība pastāv, bet arì identificēt cēlonus, noteikt tos ietekmējošos faktorus (Novick \& Morrow, 2002). Visbiežāk veselības stāvokḷa pētỉjumos un veselības stāvokḷa ietekmējošo faktoru identificēšanai tiek izmantots Jērana Dālgrēna (Göran Dahlgren) un Margaretas Vaithedas (Margaret Whitehead) veselïbas stāvokli ietekmējošo faktoru modelis (Dahlgren \& Whitehead, 1991). Modelis atspoguḷo individuālo un vides faktoru mijiedarbỉbu, kuras centrā ir cilvēks ar tam piemītošajām īpašībām, kas nav ietekmējamas, bet kurā būtu jānem vērā četru līmenu faktori, kas attiecas uz individuālo dzivesveidu jeb

individuālo uzvedību, sociālajiem un kopienas tìkliem, strukturālajiem apstākḷiem, sociālajiem, ekonomiskajiem, kultūras un vides apstākḷiem.

Tāpat, lai skaidrotu veselības stāvokḷa nevienlīdzību un identificētu veselības stāvokli ietekmējošos faktorus, bieži tiek izmantotas četras pieejas: uzvedības/kultūras, materiālistu, psihosociālā un dzīves gājuma pieeja (Bartley, 2004). Katra pieeja piedāvā savu cēloṇsakarību skaidrojumu par veselības stāvokḷa nevienlīdzību. Uzvedības/kultūras pieejā tiek pieṇemts, ka veselības stāvokla nevienlīdzību veicina atškirības sociālo škiru uzvedībā, savukārt materiālistu pieejā - ka veselības stāvokḷa nevienlīdzību veicina nabadzība, cilvēku finansiālais stāvoklis un tā atšķirības. Psihosociālajā pieejā tiek pienemts, ka sociālā nevienlīdzība var ietekmēt to, kā cilvēki jūtas psiholoğiski, un tas var ietekmēt un arì ietekmē fiziskā ḳermena procesus. Dzīves gãjuma pieeja paredz, ka visas sociālās, psihosociālās, bioloğiskās priekšrocības vai ierobežojumi ietekmē veselības stāvokḷa nevienlīdzỉbu, skatot individuālās pieredzes kontekstā (Bartley, 2004). Visas minētās pieejas un J. Dālgrēna un M.Vaithedas modelis piedāvā konkrētus veselïbas stāvokli ietekmējošus faktorus, kas izmantoti šo faktoru operacionalizācijā arī šajā pētijumā.

Empīiskās dalas metodologijia un veselības stāvokla nevienlídzība: to skaidrojošais apkopotais modelis
Par pamatu metodoloğijas konstrukcijai un izpētē iekḷaujamo indikatoru identificēšanai izmantots J. Dālgrēena un M.Vaithedas izveidotais veselïbas stāvokli ietekmējošo faktoru modelis (Dahlgren \& Whitehead, 1991) un četras veselības stāvokla nevienlīdzibu skaidrojošās pieejas: uzvedības/kultūras, materiālistu, psihosociālā un dzīves gājuma pieeja (Bartley, 2004). Ir identificēti modeḷa līmeņiem un pieejām atbilstošie faktori, konceptuālie pienēmumi un izveidots apkopojošais modelis, kas atspogulo izpētē iekḷujamos indikatorus.

Pētījumā izmantotas kvantitatīvās un kvalitatīvās izpētes metodes. Balstoties uz izstrādāto modeli ar identificētajiem indikatoriem, tika izveidota aptaujas anketa un veikta aptauja. Pētijuma metode ir anketēšana tiešās aptaujas respondentu dzīvesvietās, ǵenerālā kopa - Latvijas iedzivotāji. Izlase -1007 respondenti saskanāa ar statistisko kḷudu, kas ir ap $\pm 3 \%$ (Manheim \& Rich, 2006, p. 391). Respondentu skaits noteikts proporcionāli iedzivotāju skaitam statistiskajos reǵionos, republikas pilsētās un novados. Izlase tika veidota saskaņā ar nejaušās izlases veidu un maršruta metodi. Aptauja veikta 2014. gadā. Kvantitativā datu analizze veikta, izmantojot aptaujas datu rezultātus un analīzi SPSS programmā. Kvalitatīvā datu analīze veikta NVivo programmā, iekḷaujot Latvijas Republikas Veselības ministrijas rīcībpolitikas dokumentu kontentanalīzi. Analīzē ietverti visi pieejamie attīstības plānošanas dokumenti, kas ir pieejami identiskā laika posmā, kad tika veikta anketēšana, 
1. attēls. Veselības stāvokḷa nevienlīdzību skaidrojošais

\section{apkopotais modelis ar izpētē iekḷaujamajiem indikatoriem}

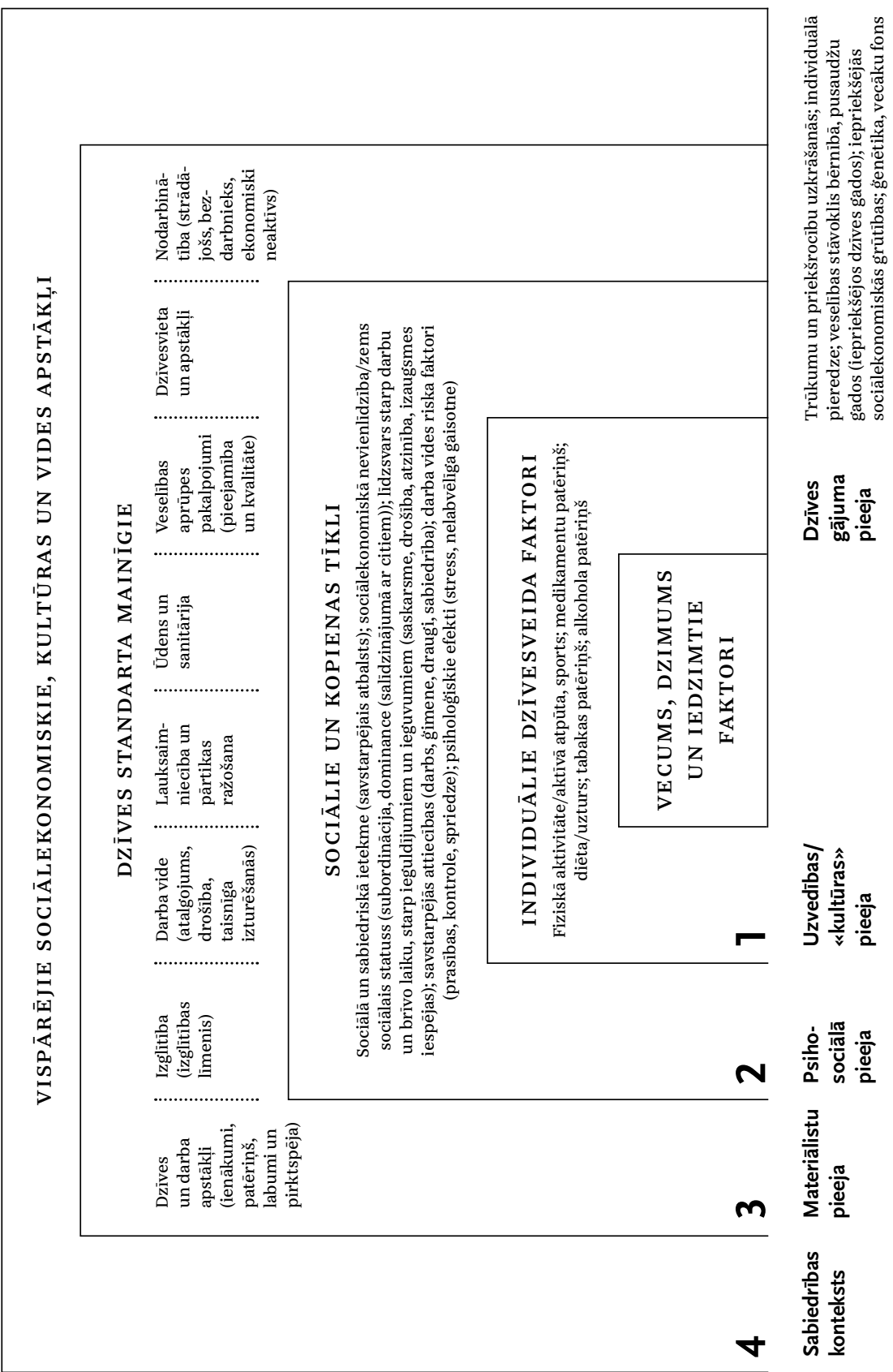

un tie dokumenti, kas attiecas uz aktuālu plānošanas periodu. Izpēte veidota trīs dalāās, kur katrai daḷai konstruētas saistošās izpētes metodes.

Pirmajā izpētes posmā ir identificēti būtiskākie demogrāfiskie mainīgie attiecībā uz veselības stāvokla nevienlīdzību pašnovērtējuma kontekstā. Otrajā izpētes posmā identificēti veselības stāvokla nevienlīdzìbu ietekmējošie sociālekonomiskie faktori pašnovērtējuma kontekstā. Izpētes trešajā posmā veikta gan kvantitatīvā, gan kvalitativā datu analīze, savstarpēji salìdzinātas konstatētās tendences rīcībpolitikas dokumentos un otrās izpētes dalas rezultātos. Konstatēto tendenču savstarpējā salīdzinājuma rezultātā tika konstruētas rekomendācijas rīcibpolitikām. Rezultātu, secinājumu un rekomendāciju apkopojums atspogulots izpētes dalās. Tas nodrošina to secīgumu, pārskatāmību un konsekvenci atbildēs uz izvirzìtajiem izpētes jautājumiem.

\section{Veselības stāvok!̣a nevienlïdzība un \\ demogrāfiskie mainīgie}

Pirmajā izpētes daḷā tiks rasta atbilde uz jautājumu - kāda iedzīvotāju veselības stāvokḷa nevienlīdzība pastāv Latvijā? At-

bilde rodama, analizējot konstatētās tendences starp veselības stāvokḷa pašnovērtējumu un demogrāfiskajiem mainīgajiem. Izpētē ir iekḷauti šādi demogrāfiskie mainīgie: valoda (aizpildītās anketas valoda), dzivesvieta (plānošanas reǵiionu sadalījums), vecums, dzimums, mājsaimniecībā dzīvojošo personu skaits, ğimenes stāvoklis, augstākā pabeigtā izglìīiba, vidējie mēneša ienākumi, nodarbinātība (strādājošs, bezdarbnieks, ekonomiski neaktīvs), pastāvigā dzivesvieta (pilsētas centrā, pilsētas teritorijāārpus centra, apkaimē ārpus pilsētas teritorijas, mazapdzīvotāā lauku teritorijāā). Atbilstoši katram mainigajam konstatētas šādas tendences:

- atsevišşos gadijumos krievvalodīgie savu veselïbas stāvokl novērtē nedaudz sliktāk;

— dzivesvietai (plānošanas reğionos) un ǵimenes stāvoklim nav saistības ar veselïbas stāvokḷa pašnovērtējumu;

— vecumam pārsvarā ir saistỉba ar veselības stāvokl pašnovērtējumu - jo vecāks cilvēks, jo sliktāks ir vina veselïbas stāvokḷa pašnovērtējums

— atseviškos gadījumos sievietes savu veselības stāvokli novērtē kā sliktāku nekā vīrieši;

— daḷā gadījumu cilvēki ar lielāku mājsaimniecībā dzīvojošo cilvēku skaitu novērtē savu veselības stāvokli kā labāku;

- lielā dalā gadijjumu - jo zemāks ir cilvēka izglìtības līmenis un ienākumi, jo sliktāk vinš novērtē savu pašreizējo veselības stāvokli;

— cilvēki, kuru kuri pārstāv bezdarbniekus un ekonomiski neaktīvos iedzivotājus, sliktāk novērtē savu pašreizējo veselïbas stāvokli; 
— dala no tiem, kas dzīvo tālāk no pilsētas, nedaudz sliktāk novērtē savu veselības stāvokli.

Tika noteikta mainīgo nozīmīguma secība, lai identificētu būtiskākās un mazāk būtiskās sakarības starp demogrāfiskajiem mainīgajiem un veselības stāvokḷa pašnovērtējumu. Tas nodrošina ne tikai atbildi uz izvirzìto izpētes jautājumu, bet ir būtiski rīcibpolitiku prioritāšu noteikšanai. Iekḷauto demogrāfisko pazìmju secība pēc nozīmìguma (no būtiskākās uz mazāk būtisko) un pēc koeficientu vidējām moduḷ vērtībām ir šāda (sk. 1.tabulu): 1) vecums, 2) nodarbinātība, 3) izglìtības līmenis, 4) ienākumi, 5) mājsaimniecībā dzīvojošo personu skaits, 6) dzimums, 7) pastāvigās dzīvesvietas atrašanās vieta, 8) valoda, 9) ğiimenes stāvoklis, 10) dzīvesvieta (plānošanas reğions).

Saskaṇā ar veselības stāvokḷa nevienlïdzību skaidrojošo apkopojošo modeli demogrāfiskās pazimes ir cilvēkam piemitošās pazimes, kas nav ietekmējamas, bet tās būtu jānem vērā rīcỉbpolitikās. Tajās būtu jānem vērā

1. tabula. Demogrāfisko pazīmju nozīmīguma secība atbilstoši koeficientu vidējām moduḷu vērtībām

\begin{tabular}{|c|c|c|}
\hline Demogrāfiskās pazīmes & Koeficientu vidējās moduḷu vērtības & \\
\hline Dzīvesvieta (plānošanas reğions) & IIII & 0,02 \\
\hline Ģimenes stāvoklis & IIIII & 0,03 \\
\hline Valoda & IIIIIIIIIII & 0,07 \\
\hline Pastāvīgās dzīvesvietas atrašanās vieta & $|I| I|I| I||||||$ & 0,09 \\
\hline Dzimums & $|\||||||||||||||||$ & 0,10 \\
\hline Mājsaimniecībā dzīvojošo skaits & |||||||||||||||||||| & 0,12 \\
\hline Ienākumi & |||||||||||||||||||||||||||||| $\mid$ & 0,18 \\
\hline Izglitīibas limenis & |||||||||||||||||||||||||||||||||| & 0,20 \\
\hline Nodarbinātība & |||||||||||||||||||||||||||||||||||||||||||| $\mid$ & 0,26 \\
\hline Vecums & |||||||||||||||||||||||||||||||||||||||||||||||||||||||||||||||||||| & 0,38 \\
\hline
\end{tabular}

demogrāfisko pazīmju nozīmīguma secība, nosakot rīcībpolitiku prioritātes, un primārās demogrāfiskās grupas, uz kurām rīcībpolitikas ir attiecināmas vai vērstas. Visbūtiskāk veselības stāvokḷa pašnovērtējumu ietekmē vecums, nodarbinātība, izglìtỉbas līmenis un ienākumi. Gimenes stāvoklim un dzivesvietai plānošanas reǵionos nav saistības ar veselības stāvokla pašnovērtējumu, bet tas var būt būtisks arguments reğionālajās rīcībpolitikās.

\section{Veselības stāvokḷa}

nevienlïdzība un sociāl-

ekonomiskie faktori

Otrajā izpētes daḷā tiks rasta atbilde uz jautājumu - kāds ir visbūtiskākais sociālekonomiskais faktors veselības stāvokḷa nevienlīdzībai Latvijā? To nodrošina konstatētās tendences starp veselības stāvokḷa pašnovērtējumu un veselības stāvokli ietekmējošajiem sociālekonomiskajiem faktoriem. Izpētē ir ieklauti visi konstruētā veselības stāvokla nevienlīdzỉbu skaidrojošā apkopojošā modeḷa sociālekonomiskie faktori (sk. 1.att.). Modelī ir ietvertas vairākas pieejas un līmeṇi-faktoru grupas, kas ietver dažādu skaitu atšḳirīgu sociālekonomisko faktoru. Atbilstoši katrai faktoru grupai konstatētas noteiktas tendences.

\section{UZVEDİBAS PIEEJAS UN MODELA INDIVIDUĀLĀ DZİVESVEIDA FAKTORI}

- Runājot par diētu un uzturu, pastāv pretrunīga tendence: lielā dalā gadỉjumu cilvēki, kas biežāk uzturā lieto neveselīgu pārtiku, savu veselības stāvokli novērtē kā labāku. Kontrolējot vecuma mainīgo,

ir redzams, ka pārsvarā neveselīgu pārtiku lieto jaunāki cilvēki, un tieši vecuma mainīgais ir būtiski ietekmējis šo sakarību.

- Tabakas un alkohola patēriņam nav saistïbas ar veselïbas stāvokla pašnovērtējumu.

— Pārsvarā tie, kas biežāk patērē medikamentus, savu veselības stāvokli vērtē kā sliktāku. Homeopātisko medikamentu patēriṇš salīdzinoši mazāk ietekmē veselības stāvokla pašnovērtējumu.

— Lielā dalā gadijumu tie, kuru brīvā laika nodarbēm raksturīga lielāka fiziskā piepūle, savu veselības stāvokli novērtē kā labāku.

\section{PSIHOSOCIĀLĀs PIEEJAS UN MODELA SOCIĀLO UN KOPIENAS}

\section{TĪKLU FAKTOR।}

— Dạā gadījumu tie cilvēki, kas biežāk saskaras ar savstarpējo atbalstu darba kolēĝu vidū, savu veselïbas stāvokli novērtē kā labāku un tie, kas biežāk saskaras ar stresu un nelabvēlīgu gaisotni darbā, savu pašreizējo veselības stāvokli vērtē kā sliktāku. Tieši darba kolēǵiem ir nozime attiecỉbā uz veselības stāvokla pašnovērtējumu, nevis ǵiimenei, draugiem vai sabiedrībai. 
- Pārsvarā tie, kuru darba ikdienā ir lielāks līdzsvars starp ieguldījumiem un ieguvumiem, savu pašreizējo veselības stāvokli novērtē kā labāku un tie, kas biežāk saskaras ar prasībām, kontroli un spriedzi darba vidē, savu veselības stāvokli novērtē kā sliktāku.

\section{MATERIĀLISTU PIEEJAS UN MODELA TREŠĀ LĪMEN̦A FAKTOR।}

- Cilvēki ar zemāku izglìīibas līmeni un zemākiem ienākumiem savu pašreizējo veselības stāvokli vērtē kā sliktāku.

— Pārsvarā tie cilvēki, kuru darbam raksturīgāka smagāka fiziskā piepūle, kuri ir bezdarbnieki vai ekonomiski neaktīvi, savu pašreizējo veselības stāvokli vērtē kā sliktāku.

— Dạā gadijjumu tie, kuri biežāk izmanto veselības aprūpes pakalpojumus, tos vērtē kā mazāk pieejamus un mazāk kvalitatīvus, bet savu pašreizējo veselības stāvokli vērtē kā sliktāku.

- Nepastāv sakarības starp veselības stāvokḷa pašnovērtējumu un dažādiem dzivesvietas apstākḷiem un pakalpojumiem, izṇemot veselības aprūpes pakalpojumus.

\section{VISPĀRĒjO SOCIĀLEKONOMISKO, KULTŪRAS, VIDES APSTĀKL̦U UN} MODELA CETURTĀ LĪMENA FAKTORI

— Cilvēki, kas vērtē sabiedrības vispārējos sociālekonomiskos apstākḷus kā sliktākus, savu pašreizējo veselības stāvokli vērtē kā sliktāku.

\section{DZİVES GÃJUMA PIEEJAS UN MODELA VISU LITMENU FAKTORI}

\section{DZİVES GĀJUMA KONTEKSTĀ}

- Cilvēki, kuru lïdzsvars starp darbu un brīvo laiku, starp ieguldijjumiem un ieguvumiem ir uzlabojies, savu pašreizējo veselības stāvokli vērtē kā labāku.

— Dạ̄ā gadỉjumu tie, kuri savu veselības stāvokli iepriekšējos dzìves gados novērtē kā sliktāku, arī savu pašreizējo veselības stāvokli novērtē kā sliktāku.

— Iepriekšējām sociālekonomiskajām grūtībām un vecāku fonam nav saistības ar veselības stāvokḷa pašnovērtējumu.

Tika noteikta mainīgo nozīmīguma secība, lai identificētu būtiskākās un mazāk būtiskās sakarības starp sociālekonomiskajiem faktoriem un veselības stāvokḷa pašnovērtējumu. Tas nodrošina ne tikai atbildi uz izvirzìto izpētes jautājumu, bet ir būtiski rīcībpolitiku prioritāšu noteikšanai. Sociālekonomisko faktoru nozīmīguma secība (no būtiskākā uz mazāk būtisko) pēc koeficientu vidējām modulu vērtībām ir šāda (sk. 2.tabulu): 1) medikamentu patēriņš, 2) nodarbinātība (strādājošs, bezdarbnieks, ekonomiski neaktīvs), 3) veselības aprūpes pakalpojumi (pieejamība un kvalitāte), 4) dzīves un darba apstākḷi (ienākumi, patēriņšs, labumi, pirktspēja), 5) izglìtība, 6) veselības stāvoklis iepriekšējos dzīves gados, 7) psiholoğiskie aspekti (stress, nelabvēlīga gaisotne), 8) līdzsvars starp darbu un brīvo laiku, starp ieguldijjumiem un ieguvumiem (saskarsme, drošỉba, atzinība, izaugsmes iespējas), 9) fiziskās aktivitātes, aktīvā atpūta un sports, 10) sociālekonomiskā nevienlīdzība, zems sociālais statuss (subordinācija, citu dominance), 11) sociālā un sabiedrïbas ietekme (savstarpējais atbalsts), 12) darba vides riska faktori (prasības, kontrole, spriedze), 13) darba vide (atalgojums, drošǐba, taisniga izturēšanās), 14) savstarpējās attiecības (darbs, ğimene, draugi, sabiedrība), 15) dzīvesvieta un apstākḷi, 16) vispārējie sociālekonomiskie, kultūras un vides apstākli, 17) diēta un uzturs, 18) trūkumu un priekšrocību uzkrāšanās, individuālā pieredze, 19) tabakas patērinš, 20) vecāku fons, 21) alkohola patēriṇš, 22) iepriekšējās sociālekonomiskās grūtības.

Saskaṇā ar veselības stāvokḷa nevienlīdzību skaidrojošo apkopojošo modeli visi izpētē ieklautie sociālekonomiskie faktori ir ietekmējami, rīcībpolitiku piemērošana var veicināt faktoru un to ietekmes izmaiņas. Rīcībpolitikās būtu jāṇem vērā faktoru nozīmīguma secība attiecībā uz veselības stāvokḷa pašnovērtējumu, nosakot rīcibpolitiku prioritātes. Visbūtiskāk veselības stāvokḷa pašnovērtējumu ietekmē medikamentu patēriņš, nodarbinātība, veselības aprūpes pakalpojumu pieejamỉba un kvalitāte, dzives un darba apstākḷi. Faktoru ietekmes būtiskuma secība lauj secināt ne tikai par vēlamajām prioritātēm, bet arī par maznozīmīgākajiem faktoriem veselības stāvokḷa pašnovērtējuma ietekmē. Taču, ja rīcībpolitikās tiek izmantota identificētā faktoru būtiskuma secība, tā nevar tikt nošķirta no veselības stāvokla daudzdimensionālās dabas. Veselības stāvokḷ daudzdimensionālā daba paredz to, ka pastāv grūtības noteikt ietekmes virzienu - kurš kuru ietekmē. Piemēram, medikamentu patēriņš ir būtiskākais faktors, taču netiek identificēts, vai lielāks medikamentu patērinš paredz sliktāku veselības stāvokḷ pašnovērtējumu, vai sliktāks veselības stāvokḷa pašnovērtējums paredz lielāku medikamentu patēriņu. Attiecīgi rīcibpolitikās būtu jāṇem vērā faktoru būtiskums un arì ietekmes daudzdimensionalitāte.

\section{Konstatētās tendences un} veselības rīcibpolitika ar konstatētajām veselības stāvokḷa nevienlīdzības tendencēm Latvijāe Šajā izpētes daḷā veikta Veselības ministrijas rīcibpolitikas dokumentu kontentanalize, identificējot esošo rīcibpolitiku prioritātes pēc kodēto atsauču 
2. tabula. Sociālekonomisko faktoru nozīmīguma secība atbilstoši koeficientu vidējām moduḷu vērtībām

\begin{tabular}{|c|c|c|}
\hline Sociālekonomiskie faktori & Koeficientu vidējās moduḷu vērtības & \\
\hline Iepriekšējās sociālekonomiskās grūtības & IIIIIII & 0,036 \\
\hline Alkohola patēriņš & IIIIIIIIIII & 0,062 \\
\hline Vecāku fons & \|\|\|\||||||| & 0,063 \\
\hline Tabakas patēriṇš & ||||||||||||| & 0,071 \\
\hline Trūkumu un priekšrocību uzkrāšanās, individuālā pieredze & ||IIIIIIIIIII & o,076 \\
\hline Diēta un uzturs & ||||||||||||||||| & 0,087 \\
\hline Vispārējie sociālekonomiskie, kultūras un vides apstākḷi & |||I|IIIIIIIIII| & o,088 \\
\hline Dzīvesvieta un apstākḷi & |||||||||||||||| $\mid$ & 0,098 \\
\hline Savstarpējās attiecibas (darbs, ğimene, draugi) & $|\||||||||||||||||$ & 0,098 \\
\hline Darba vide (atalgojums, drošǐba, taisnīga izturēšanās) & |||||||||||||||||||||||| $\mid$ & 0,134 \\
\hline Darba vides riska faktori (prasïbas, kontrole, spriedze) & |||||||||||||||||||||||||| & 0,145 \\
\hline Sociālā un sabiedrïbas ietekme (savstarpējais atbalsts) & |||||||||||||||||||||||||||| & 0,149 \\
\hline Sociālekonomiskā nevienlïdziba & |||||||||||||||||||||||||||| & 0,150 \\
\hline Fiziskās aktivitātes, aktivā atpūta un sports & $|\|||||||||||||||||||||||||| \mid$ & 0,151 \\
\hline Lïdzsvars starp darbu un brīvo laiku & |||||||||||||||||||||||||||| & 0,152 \\
\hline Psiholoğiskie aspekti (stress, nelabvēliga gaisotne) & |||||||||||||||||||||||||||||||||||| & 0,185 \\
\hline Veselïbas stāvoklis iepriekšējos dzives gados & |||||||||||||||||||||||||||||||||||| & 0,193 \\
\hline Izglitiba & |||||||||||||||||||||||||||||||||||| $\mid$ & 0,198 \\
\hline Dzives un darba apstākḷi & |||||||||||||||||||||||||||||||||||||||| $\mid$ & 0,207 \\
\hline Veselïbas aprūpes pakalpojumi (pieejamība un kvalitāte) & |||||||||||||||||||||||||||||||||||||||||||||||||||| & 0,250 \\
\hline Nodarbinātība & ||||||||||||||||||||||||||||||||||||||||||||||||||||| & 0,259 \\
\hline Medikamentu patēriņš & |||||||||||||||||||||||||||||||||||||||||||||||||||||||||||||||||||||| & 0,335 \\
\hline
\end{tabular}

(Tripāne, 2014)
3. tabula. Veselības rīcībpolitiku prioritātes pēc kodēto atsauču skaita ar pozitīvu rīcībpolitiku satura vērtību

\begin{tabular}{|c|c|c|}
\hline \multirow{2}{*}{$\begin{array}{l}\text { Sociālekonomiskie faktori } \\
\text { Lìdzsvars starp darbu un brivo laiku }\end{array}$} & \multicolumn{2}{|l|}{ Kodēto atsauču skaits } \\
\hline & & $\mathrm{o}$ \\
\hline Darba vide (atalgojums, drošǐa, taisnīga izturēšanās) & & $\circ$ \\
\hline Dzives un darba apstākḷi & & $\circ$ \\
\hline Iepriekšèjās sociālekonomiskās grūtības & & $\mathrm{o}$ \\
\hline Izglitiba & & o \\
\hline Dzīvesvieta un apstākḷi & & $\circ$ \\
\hline Psiholoğiskie aspekti (stress, nelabvēliga gaisotne) & & $\circ$ \\
\hline Savstarpējās attiecibas (darbs, ğimene, draugi, sabiedriba) & & $\circ$ \\
\hline Sociālā un sabiedrỉbas ietekme (savstarpējais atbalsts) & & $\circ$ \\
\hline Nodarbinātiba & II & 2 \\
\hline Darba vides riska faktori (prasibas, kontrole, spriedze) & II & 2 \\
\hline Fiziskās aktivitātes, aktivāa atpūta un sports & ॥ & 2 \\
\hline Vecāku fons & ॥ & 2 \\
\hline Tabakas patēriṇš & II & 2 \\
\hline Trūkumu un priekšrocību uzkrāšanās, individuālā pieredze & IIII & 4 \\
\hline Diēta un uzturs & IIIIII & 6 \\
\hline Veselïbas stāvoklis iepriekšējos dzives gados & IIIIII & 6 \\
\hline Medikamentu patēriṇš & IIIIIIII & 8 \\
\hline Sociālekonomiskā nevienlïdzība & IIIIIIII & 8 \\
\hline Vispārējie sociālekonomiskie, kultūras un vides apstākḷi & IIIIIIII & 8 \\
\hline Alkohola patēriṇš & |IIIIIIIIIII & 14 \\
\hline Veselïbas aprūpes pakalpojumi (pieejamība un kvalitāte) & |||||||||||||||||||||||||||||||||||||| $\mid$ & 69 \\
\hline
\end{tabular}

(Tripāne, 2014) 
skaita ar pozitīvu rīcībpolitiku satura vērtību. Lai rastu atbildi uz trešajā izpētes dạ̦ā formulēto jautājumu, tika salīdzinātas otrajā izpētes dạ̣ā konstatētās tendences ar esošo rīcibpolitiku prioritātēm pēc kodēto atsauču skaita (sk. 3.tabulu).

Salīdzinot otrajā izpētes daḷā konstatētās tendences ar rīcībpolitiku prioritātēm pēc kodēto atsauču skaita, tika rasti secinājumi ar rekomendējošu raksturu provizoriskajām rīcībpolitikām un rīcībpolitiku prioritātēm. Respondenti kā būtiskākos sociālekonomiskos faktorus attiecībā uz veselības stāvokḷa pašnovērtējumu norāda medikamentu patēriṇu, nodarbinātību, veselības aprūpes pakalpojumu pieejamību un kvalitāti, dzives un darba apstāklus. Iepretī tiem kā nebūtiski rīcibpolitikas dokumentos visbiežāk norādīti tādi faktori kā veselības aprūpes pakalpojumu pieejamība un kvalitāte, alkohola patēriṇš, vispārējie sociālekonomiskie un kultūras apstākḷi un sociālekonomiskā nevienlīdzība, zems sociālais statuss.

Nemot vērā arī pārējo faktoru secīgumu, tiek konstatēts: kaut gan lielā dạ̣ā gadỉjumu respondentu un rīcībpolitikas dokumentu prioritātes attiecībā uz veselības stāvokli ir tuvas, taču pārsvarā to secīgums pēc būtiskuma nesakrìt. Piemēram, respondentu norādìtais nodarbinātības faktors (strādājošs, bezdarbnieks, ekonomiski neaktīvs) vai dzìves un darba apstākḷu faktors, kas iekḷaujas piecos būtiskākajos, nav starp rīcibpolitikas dokumentos biežāk minētajiem. Piemēram, rīcībpolitikas dokumentos biežāk norādītie faktori ir sociālekonomiskā nevienlīdzība, vispārējie sociālekonomiskie, kultūras un vides apstākḷi, kā arī alkohola patēriņšs, taču respondentu atbildēs tie atrodas nebūtiskāko starpā.

Svarīgi ir atzīmēt būtisku tendenci, ka liela daḷa faktoru vispār netiek ņemti vērā formulētajās rīcībpolitikās, piemēram, dzīves un darba apstākḷi (atrodas starp respondentu norādītajiem būtiskākajiem), izglìitibas līmenis, psiholoğiskie aspekti, līdzsvars starp darbu un brīvo laiku, sociālā un sabiedrības ietekme, darba vide, savstarpējās attiecības, dzìvesvieta un apstākḷi, iepriekšējās sociālekonomiskās grūtības. Attiecīgi rỉcỉbpolitikās būtu jāpievēršas faktoriem, ne tikai nosakot prioritātes, bet arī iekḷaujot prioritātes rīcībpolitiku dokumentos un ietekmes laukā.

Veselības stāvokḷa pašnovērtējums ir būtisks aspekts veselïbas rīcībpolitikās, jo veselības rīcibpolitikas ir vērstas uz cilvēku un veselības stāvokḷ pašnovērtējums ietver cilvēku objektīvo pieredzi, priekšstatus, kas ir saistîti ar objektīviem pamatiem realitātē un atspoguḷo arī personas realitātes redzējumu. Gadījumā, ja rīcībpolitikās netiek ṇemts vērā veselības stāvokḷa pašnovērtējums (subjektīvā evidenču perspektīva), pastāv būtisks rīcībpolitiku risks, jo netiek n,emta vērā viena no divām (objektīvā un subjektīvā) veselības stāvokḷa perspektīvām. Piemēram, cilvēki var justies labi, kaut gan objektivie faktori vinu dzivē to neparedz. Subjektivo faktoru lietojums balstās uz pienēmumu, ka labklājỉba pamatā ir atkarīga no indivìdu pašnovērtējuma, jo individds vislabāk spēj novērtēt to, kas vinam ir būtiskākais, kas ir labi un kas ir slikti (Noll, 2000). Veselības stāvokla pašnovērtējuma analīze un ieklaušana rīcībpolitikās nodrošina skatījumu par indivìda izpratni un uztveri, vina pozīciju saistībā ar fizisko un mentālo veselību (Phillips, 2006), labas dzīves priekšstatiem, subjektīvajiem priekšnoteikumiem rīcībai un apmierinātībai ar veselību un citiem dzìves aspektiem. Veselības stāvokḷa pašnovērtējums var būt kā mainīgais, prognozējot un nosakot veselības aprūpes sistēmas iespēju izmantošanu, mirstību un citus būtiskus mainīgos (DeSalvo et al., 2005). Veselības stāvokḷa pašnovērtējums iekḷauj visus veselības stāvokli raksturojošos aspektus, un subjektīvā pašsajūta ietekmē veselības stāvokli. Veselības stāvokḷa pašnovērtējums norāda uz veselības problēmām, ir mirstības paredzēšanas mainīgai (Ginzler, 2010) un tiek klasificēts kā «spēcīgā» evidence (Fayer \& Hays, 2005; McFadden et al., 2008). Vairāki pētỉjumi apstiprina, ka veselības stāvokl pašnovērtējumam ir tikpat nozimīga ietekme uz veselỉbu un ar veselību saistītu uzvedību kā objektīvajiem mainigajiem, taču šĩ ietekme nereti var būt atšḳirìga (Mossey \& Shapiro, 1982). Tādēḷ rīcībpolitikās ir būtiski ṇem vērā cilvēku noteiktās prioritātes, ieklaujot norādītās prioritātes un ievērojot norādīto prioritāšu secību. Rīcībpolitiku prioritātes pēc prioritāšu iekḷaušanas biežuma rīcībpolitikas dokumentos absolūti atšķiras no respondentu norādītajām. Atšķirigia ir prioritāšu noteikšana un noteikto prioritāšu būtiskuma secība.

Veselības stāvokḷa nevienlīdzība liecina, ka veselïbas aprūpes pakalpojumi neaizsargā cilvēkus no veselības stāvokla sekām, kas ir saistītas a dažādiem sociālekonomiskajiem faktoriem (Bakker \& Mackenbach, 2004, p. 35). Veselības stāvokḷa nevienlīdzības novēeršana rīcībpolitikās ir sarežǧîits mērḳis, jo nevienlīdzībai nereti ir cieša saikne ar tādiem faktoriem kā labklājība, izglìtỉba, ienākumi, vide un citiem, kas nevar tikt novērsti vienkāršā veidā, îstenojot noteiktas rīcībpolitikas veselības aprūpes sistēmā (Killoran \& Kelly, 2010). Taču rīcībpolitikām var būt izšḳiroša loma nevienlīdzības radīto, potenciālo un postošo seku vai iemeslu novēršanā vai likvidēšanā (Eurostat, 2015). Sabiedrības rīcībpolitikām ir jābūt formulētām tā, lai tās varētu ietekmēt indivīdu dzīves realitāti, un viens no būtiskiem indivìda dzīves realitātes aspektiem ir pašnovērtējums. Tas norāda uz to, ka veselības stāvokḷa nevienlīdzība ir starpsektoru rīcībpolitikas jautājums, jo veselības stāvokla nevienlīdzību ir iespējams ietekmēt, «sinhronizējot» dažāda līmeṇa, dažādu jomu rīcībpolitikas un dažādus rīcỉbpolitiku aspektus, kuriem var būt gan tieša, gan netieša, gan pastarpināta ietekme uz cilvēku veselības stāvokli. Veselỉbas rīcībpolitikas, bez šaubām, ietekmē cilvēku veselïbas stāvokli un dažādos ar to saistītos aspektus, bet tieši tāpat kā šis nodaḷas konstruētais veselïbas stāvokla nevienlīdzību skaidrojošais apkopojošais modelis ietver daudzus veselības stāvokli ietekmējošos faktorus vairākos modela līmenos, 
arī dažāda līmena, dažādu jomu rīcībpolitikas un dažādi rīcībpolitiku aspekti ir savstarpēji saistīti, ietekmējot cilvēku veselības stāvokli. Piemēram, izglītỉbas rīcībpolitikas ietekmē izglìtỉbas pieejamību un kvalitāti, tā ietekmējot izglìtības līmeni; sociālās rīcībpolitikas ietekmē un nosaka daudzus sociālās un ekonomiskās aizsardzības aspektus, piemēram, nodarbinātību, ğimenes aizsardzību, un tas savukārt var ietekmēt veselības stāvokli. Tādēl arì veselïbas stāvoklis, veselības stāvokḷa nevienlïdzỉba un veselïbas stāvokḷa pašnovērtējums ir būtiska dala no kopējās rīcībpolitiku sistēmas.

\section{Izmantotie avoti}

Achinstein, P. (2005). Scientific Evidence: Philosophical Theories and Applications. Baltimore: JHU Press, pp. 38-39.

Andresen, E., \& DeFries Bouldin, E. (2010). Public Health Foundations: Concepts and Practices. USA: John Wiley \& Sons, pp. 388-389.

Bakker, M., \& Mackenbach, J. (2004). Reducing Inequalities in Health: A European Perspective. USA: Routledge, p. 35 .

Bartley, M. (2004). Health Inequality: An Introduction to Theories, Concepts and Methods. Cambridge: The Policy Press.

Best, A. (2009). Evidence: Examples \& Explanations. Frederick: Aspen Publishers Online, p. 105.

Bjorner, J., Fayers, P., \& Idler, E. (2005). Self-rated health. In P. M. Fayers, R. D. Hays, Assessing Quality of Life in Clinical Trials: Methods and Practice (pp. 309-324) (2nd ed.). New York: Oxford University Press.

Braveman, P. (2006). Health disparities and health equity: Concepts and Measurement. Public Health, 27, pp. 167-194.

Brownson, R.C., Baker, E. A., Leet, T. L., Gillespie, K. N., \& True, W. R. (2004). Evidence-Based Public Health. Oxford: Oxford University Press, p.184.

Dahlgren, G., \& Whitehead, M. (1991). Policies and strategies to promote social equity in health. Stockholm: Institute for Future Studies.

DeSalvo, K. B., Fan, V. S., McDonell, M. B., \& Fihn, S. D. (2005). Predicting Mortality and Healthcare Utilization with a Single Question. Health Services Research, 40(4), pp. 1234-1246.

EuroHealthNet (n.d.). Latvia. Retrieved from http://www.health-inequalities.eu/ HEALTHEQUITY/EN/about_hi/health_inequalities/latvia/

European Commission (2013). Health inequalities in the EU. Retrieved from http://ec.europa.eu/health/social_determinants/docs/ healthinequalitiesineu_2013_en.pdf

Eurostat (2015). Life expectancy at birth, by sex. Retrieved from http://ec.europa.eu/ eurostat/tgm/table.do?tab=table\&plugin=1\&language $=$ en\&pcode $=$ tpsooo25
Eyal, N., Hurst, S. A., Norheim, O.F., \& Wikler, D. (2013). Inequalities in Health: Concepts, Measures, and Ethics. New York: Oxford University Press, p. 6.

Fayers, P. M., \& Hays, R. D. (2005). Assessing Quality of Life in Clinical Trials: Methods and Practice (2nd ed.). New York: Oxford University Press, p. 314

Fotso, J.C., \& Kuate-Defo, B. (2005). Measuring socioeconomic status in health research in developing countries: should we be focusing on households, communities or both? Social Indicators Research, 72(2), pp.189-237.

Fuchs, V.R. (2004). Reflections on the socio-economic correlates of health. Journal of Health Economics, 23(4), pp. 653-661.

Ginzler, E. M. (2010). Systemic Lupus Erythematosus, Rheumatic Disease Clinics of North America. Elsevier Health Sciences, p. 20.

Graham, H. (2009). Understanding Health Inequalities (2nd ed.). Berkshire: Open University Press.

Kawachi, I., Subramanian, S. V., \& Almeida-Filho, N. (2002). A glossary for health inequalities. The Journal of Epidemiology and Community Health, 56(9), pp. 647-652.

Killoran, A., \& Kelly, M.P. (2010). Evidence-based Public Health: Effectiveness and Efficiency. Oxford: Oxford University Press, pp. 63-64, p. 148.

King's College London (n.d.). The Importance of Evidence-Based Policy Making. Retrieved from http://www.kcl.ac.uk/aboutkings/facts/

Manheim, J.B., \& Rich, R.C. (2006). Empirical political analysis. New York: The Lehigh Press, p. 391.

McFadden, E., Luben, R., Wareham, N., Kinmonth, A. L., \& Khaw, K. T. (2008). Social inequalities in self-rated health by age: Cross-sectional study of 22457 middle-aged men and women. BMC Public Health, 8(230).

McKeown, P. (2014). Evidence. Oxford: Oxford University Press, pp. 6-7.

Ministru kabinets (2014, 17. okt.). Par Sabiedrïbas veselības pamatnostādnēm 2014.-2020. gadam. Latvijas Vēstnesis, 206. Izgūts no http://polsis.mk.gov.lv/ LoadAtt/fileg234.doc

Monden, C.W. S. (2004). Socioeconomic health inequalities in Latvia: a crosssectional study. Scandinavian Journal of Public Health, 32(3), pp. 217-223.

Mossey, J.M., \& Shapiro, E. (1982). Self-rated health: a predictor of mortality among the elderly. American Journal of Public Health, 72(8), pp. 800-808.

Noll, H.H. (2000). Social indicators and social reporting: the international experience. Retrieved from http://www.ccsd.ca/noll1.html

Novick, L.F., \& Morrow, C. B. (2002). Defininig public health: historical and contemporary developments. Jones and Bartlett Publishers, pp.1-31.

Nutley, S. M., Davies, H.T. O., \& Smith, P.C. (2000). What Works? Evidence-Based Policy and Practice in Public. Bristol: The Policy Press.

OECD (2008). Inequalities in Health Care Use in OECD countries. Retrieved from http://www.oecd.org/health/inequalities 
Phillips, D. (2006). Quality of Life: Concept, Policy and Practice. New York: Routledge, pp. 15-39.

Shaxson, L. (2005). Is your evidence robust enough? Questions for policy makers and practitioners. Evidence \& Policy: A Journal of Research, Debate and Practice, 1(1), p.102.

Tripāne, M. (2014). Veselības stāvokḷa nevienlīdzìba Latvijā. Rỉga: Latvija Universitāte.

Twining, W.L. (1985). Theories of Evidence: Bentham and Wigmore. Stanford: Stanford University Press, pp. 66-69.

World Health Organization (1946). Official Records of the World Health Organization, p.100. 


\section{Ceḷā uz cieṇpilnu dzīvi}




\section{Ilgtspējas sociālā dimensija:
vai virzāmies pretī labklājỉbai \\ Ilğtspējas sociālā dimensija:
vai virzāmies pretī labklājíbai un cien,pilnai dzivei?}


Nabadzības samazināšanas

un pienācīgas dzīves politiskais nozīmigums un zinātniskā interpretācija
Jau 1992. gadā ANO Riode- 1 Neoficiāls biedribas žaneiro konferencē par «LAPAS» tulkojums, kas lievidi un attīstỉbu pienēèma tots arī Pārresoru koordi deklarāciju «Rīcības plāns 21. gadsimtam», kurā no- stiprināja izpratni par ilgtspējigas attistibas principiem un pirmo izvirzīja nabadzības mazināšanas jautājumu. Deklarācijas centrā ir ideja par labāku pasauli tagad un arī nākošajām paaudzēm - uzsverot nepieciešamỉbu apmierināt pamata vajadzības un uzlabot dzives standartus visiem, vienlaikus aizsargājot dabas ekosistēmas, lỉdzsvarojot un integrējot vides un attīstïbas jautājumus (United Nations Conference, 1992). Kopš tā laika visu līmeṇu attīstības plānošanā (starptautiskā, nacionālā un lokālā mērogā) arvien detalizētāka uzmanība pievērsta sociālās attīstības jautājumiem - nabadzỉbas un nevienlīdzības mazināšanai, pamata pakalpojumu pieejamībai un sociālās drošības nostiprināšanai. No vides aizsardzības un humānisma ideālu vizzijas pamazām attīstijies sazarots ilgtspējigas attīstības mērḳu tỉkls ar konkrētiem rezultātu mērišanas indikatoriem. 2015. gada septembrī Apvienoto Nāciju Organizācija pieñēma rezolūciju «Mūsu pasaules pārveidošana: Ilgtspējigas attīstības programma 2030. gadam ${ }^{1}$, kuras pamata ideja ir samazināt nabadzìbu, aizsargāt planētu un nodrošināt labklājỉbu visiem. Būtiski mērḳi ir veidot pasauli, kas ir iekḷaujoša un sniedz iespēju ikvienam dzivot ar cieṇu, isstenojot cilvēktiesību pamatvērtības (United Nations General Assambly, 2015).

Mūsdienu ilgtspējīgas attīstības izpratnei būtiskas ir ekonomista Amartijas Sena (Amartya Sen) idejas, saskanāa ar tām attīstība nozīmē cilvēka brīvïbu paplašināšanos, nevis vienkārši iekšzemes kopprodukta vai personisko ienākumu kāpumu, kas ir tikai lïdzekḷi brīiibas îstenošanai (Sen, 1999). Pētnieka skatījumā brīiviba ir attīstības priekšnosacijums - attīstỉba ir iespējama tikai kā cilvēku brīvas darbības rezultāts. Savukārt attīstībai ir jāsniedz brīvība no nabadzības, brīvība no sistemātiskas sociālas deprivācijas, kā arī brīvỉba no citiem ierobežojumiem. Var teikt, ka nabadzības mazināšanas izškirirošã nozime balstās uz nepieciešamỉbu veidot labvēligus priekšnoteikumus cilvēka brīvai attīstỉbai, kas savukārt ir cilvēktiesību centrā.

Arvien aktuāls ir jautājums par nabadzības definēšanu un zinātniski pamatotu metodoloǵiju nabadzỉbas izpētē, lai noskaidrotu, vai mēs kā sabiedrība efektīvi samazinām nabadzību, sociālo atstumtību un materiālo nenodrošinātỉbu, kā sasniedzam izvirzitos mērḳus labklājības paaugstināšanai visiem iedzīvotājiem. Plaši lietotajā relatīvās nabadzỉbas mērīšanas pieejā cilvēks tiek uzskatîts par nabadzigu, ja ekvivalentais vina rīcībā esošais ienākums ir zem 60\% no nacionālā ekvivalentā personas rỉcỉbā esošā ienākuma mediānas, - tā ir skaidra, relatīvi vienkārša pieeja, un ar tās palīdzību var iegūt starptautiski salīdzināmus rāditājus. Tomēr ir viena problēma - šis rādītājs ir piesaistīts vidējiem ienākumiem valstī un faktiski neparāda, kādu dzives kvalitāti ar mājsaimniecības rīcỉbā esošiem lídzekliem tā var nodrošināt. Zinātnieki uzskata, ka ienākumu un nodarbinātības rādītāji paši par sevi ir nepietiekami, lai pamatoti izmērītu nabadzību un sociālo atstumtību (Gordon et al., 2000). Pētnieki uzskata, ka dzilāka izpratne un kompleksāka pieeja nabadzības, nenodrošinātības un sociālās atstumtības izpausmju mērīšanā var palīdzēt veidot efektīvāku rīcībpolitiku šo nevēlamo sociālo parādību mazināšanai un novēršanai.

Nabadzības un sociālās atstumtības izpratne politikas plānošanā un zinātnē būtiski atšḳiras. Valsts statistiskajos rādītājos un politikas plānošanas vajadzībām pamatā lieto relatīvās nabadzības mērīšanas pieeju un trīs indikatorus, kurus visus kopā mēdz apzīmēt ar nabadzības vai sociālās atstumtības riska jēdzienu - nabadzības riska slieksnis, materiālā nenodrošinātība un mājsaimniecības darba intensitāte.

lenākumu dimensijā par nabadzigiem uzlūko cilvēkus, kuru ienākum ir zem vidèjā ienākumu rādītāja valstī. Eiropas Savienībā statistikas vajadzībām pieṇem, ka nabadzības slieksnis ir «60\% no rīcībā esošo ienākumu mediānas, pārrēḳinātas uz ekvivalento patērētāju skaitu mājsaimniecībā» (Centrālā statistikas pārvalde, 2017a). Apsekojumā «Eiropas Savienības statistika par ienākumiem un dzìves apstākḷiem» (EU SILC) materiālā nenodrošinātība tiek definēta kā iemeslu kopums, kas mājsaimniecībai liedz pieeju noteiktiem materiāliem labumiem. Šie iemesli ir naudas trūkums, neapmierinoši mājokḷa apstākḷi un piespiedu atteikšanās izmantot ilglietošanas sadzives priekšmetus. Materiālās nenodrošinātības indekss raksturo tādu personu īpatsvaru, kurām piemīt vismaz trīs materiālās nenodrošinātības pazimes, kas saistìtas ar finansiālu iespēju trūkumu 1) segt komunālos maksājumus, ìri vai atmaksāt kredītu, 2) finansiāli aț̣auties uzturēt mājokli siltu, 3) seg pēkšṇus, neparedzētus izdevumus no pašu līdzekḷiem, 4) ēst gaḷu, putnu galu vai zivis (vai atbilstošu veǵetāro maltīiti) katru otro dienu, 5) katru gadu vienu nedēḷu doties brīvdienās ārpus mājām (nepaliekot pie radiniekiem), 6) lietot savām vajadzībām vieglo auto, 7) iegādāties veḷas mazgājamo mašīnu, 8) iegādāties krāsu televizoru, 9) iegādāties telefonu (Centrālā statistikas pārvalde, 2017a). Savukārt darba intensitāte ir darbspējas vecuma mājsaimniecības locekḷu nostrādāto mēnešu skaita attiecība pret kopējo mēnešu skaitu, ko mājsaimniecības locekḷi teorētiski varēja nostrādāt periodā, par kuru tiek veikta izpēte. Tiek uzskatīts, ka persona dzīvo mājsaimniecībā ar zemu darba intensitāti, ja visu tās darbspējas vecuma mājsaimniecības locekḷu pārskata periodā nostrādāto mēnešu skaita attiecība pret kopējo mēnešu skaitu, ko mājsaimniecības locekli teorētiski varēja nostrādāt, ir zem 20\% (Labklājibas ministrija, 2014a).

Sociālajās zinātnēs tiek piedāvāts niansētāks skatījums uz nabadzības problēmu, kas ietver daudzdimensionālu nenodrošinātības izpratni, līdzās materiālo un finanšu resursu trūkumam aplūkojot arī prasmju, fizisko spēju, 
rīcībspējas un pašcienas deprivāciju, kas kopumā traucē ieklauties sabiedrībā (Lāce, 2012). Sociālajās zinātnēs dod priekšroku plašākajam sociālās atstumtības jēdzienam, kas vairāk akcentē sociālās attiecības un nespēju piedalīties sabiedrības dzivēe. Arī Apvienoto Nāciju Organizācijas nabadzỉbas izpratne, kas definēta Pasaules sociālajā samitā 1995. gadā, ir samērā plaša:

Nabadzībai ir dažādas izpausmes, kas ietver ienākumu trūkumu un tādu produktīvu resursu trūkumu, kas nenodrošina ilgtspējigu dzivotni, bet ietver izsalkumu un nepietiekošu pārtiku, sliktu veselỉbu, ierobežotu pieeju vai pieejas trūkumu izglitïbai un citiem pamata pakalpojumiem, paaugstinātu mirstỉbu un mirstïbu no slimībām; bezpajumtniecību un neatbilstošus mājokḷa apstākḷus, nedrošu apkaimi, kā arī sociālo diskrimināciju un atstumtỉbu. To raksturo arī līdzdalības trūkums lēmumu pieṇemšanā, pilsoniskajā, sociālajā un kultūras dzivē (United Nations, 1995, p. 38).

Arī Eiropas Savienībā pieṇemtā nabadzỉbas definīcija ietver kompleksu skatijumu uz daudzveidīgajiem ierobežojumiem, kas liedz cilvēkiem pilnvērtīgi piedalīties sabiedrības dzivē un dzìvot atbilstoši dzīves līmenim, kuru par normu uzlūko konkrētā sabiedrībā:

Var uzskatît, ka cilvēki dzīvo nabadzībā, ja vinu ienākumi un resursi nav atbilstoši, lai varētu atlauties tādu dzives standartu, kāds tiek uzlūkots par pieṇemamu sabiedrībā, kurā viṇi dzīvo. Savas nabadzỉbas dēl viṇi var piedzìvot dažādas grūtības (disatvantages), kā bezdarbu, zemus ienākumus, sliktu mājokla kvalitāti, neatbilstošu veselïbas aprūpi un ierobežotu pieeju mūžizglitỉbai, kultūrai, sportam un atpūtai. Viṇi ir izstumti no līdzdalības ekonomiskajās, sociālajās un kultūras aktivitātēs, kuras citi cilvēki uzlūko kā normu, un arī vinu tiesibu istenošana var būt ierobežota (Council of the European Union, 2004, p. 8).

Diskusijās par piemērotākajiem rādītājiem nabadzības un sociālās atstumtības mērišanai pētnieki uzsver, ka būtiski ir aptvert visus dzīves aspektus. Lìdz šim statistikā plašāk lietotie rādītāji (kurus aplūkojām iepriekš) ir pamatā fokusēti uz materiālajiem resursiem un minimāli ietver pat fokusu uz nodarbinātỉbu. Tie nelauj saprast, vai ar savā rīcībā esošajiem ienākumiem cilvēki var nodrošināt pieṇemama dzìves līmeṇa minimumu, kas ietver arī sociālās, pilsoniskās un kultūras aktivitātes. Zinātnieki norāda, ka, līdzigi kā globālās sasilšanas gadijjumā ir izstrādāti precīzi indikatori un sliekšņi, kas l̦auj spriest par riskiem siltumnīcefekta pieaugumam, arī attiecībā uz nabadzību vajadzētu izstrādāt kritērijus, kas palīdz noteikt, pie kāda ienākumu sliekšṇa ir augsts risks, ka cilvēki sastapsies ar dažādām nenodrošinātības formām (Gordon et al., 2000).
Tāda skatījuma iegūšanai, kas aptvertu visus dzives aspektus, pamatā tiek lietotas divas pieejas - dzìves kvalitātes mērỉjumi un mājsaimniecību patēriṇa grozu aprēḳini. Atkarībā no izvēlētās konceptuālās pieejas, tiek lietoti jēdzieni «atsauces budžets», «iztikas minimuma patēriṇa grozs» un «pienācīgas dzīves patērina grozs». Vienojošais ir tas, ka visos gadijumos tiek pētîts, kādā veidā matemātiski pieṇemtie ienākumu sliekšṇi saistās ar mājsaimniecību reālajām patēriṇa vajadzībām. Atškirīigais ir tas, vai tiek pievērsta uzmanība minimālo vajadzību nodrošināšanai vai pienācịga dzīves lïmeṇa nodrošināšanai nepieciešamajiem labumiem, pakalpojumiem un aktivitātēm. Piemēram, Somijā zinātnieku un politikas veidotāju vidū valda pārliecība, ka 21. gadsimtā labklājības valstīs nevajadzētu runāt tikai par izdzīvošanas vajadzību apmierināšanu, bet jāskatās uz pieṇemamu dzìves standartu kā atsauces normu (Lehtinen et al., 2011).

Pastāv uzskats, ka tieši cilvēktiesību deklarācijā pirmo reizi ir sniegts pārskats par to, kas ikvienam cilvēkam ir nepieciešams labas dzīves minimumam vai pienācīgai dzìvei (decent life) (Buchanan, 2005). Vispārējās cilvēktiesības ietver tiesỉbas uz sociālo drošìbu un cilvēka pašciennas uzturēšanai un personības brivai attīstībai nepieciešamo tiesību îstenošanu ekonomiskajā, sociālajā un kultūras jomā (ANo Vispārējā cilvēktiesību deklarācija, 1948). Praksē pētnieki retāk veido uz cilvēktiesībām balstītu pamatojumu pienācīgas dzīves konceptualizācijai un drīzāk pieiet lietiški, kā kritēriju izvirzot priekšstatus par dzives standartu, kuru par normu uzskata konkrētā sabiedrībā. Zinātnieki norāda, ka priekšstati par precēm, pakalpojumiem un aktivitātēm, kas piederas pienācīgas dzīves nodrošināšanai, ir laika gaitā mainīgi arī vienā sabiedrībā (Suter \& Iglesias, 2005; Lehtinen et al., 2011).

Ir būtiski pievērst uzmanību gan tam, ko cilvēki var ațlauties, gan tam, ko vini nevar atlauties. Lielbritānijā 1998. gadā tika uzsākts liela apjoma pētījums, kurā nabadzības izpētes operacionalizācijā tika integrēts ANo definētais plašais skatijjums uz nabadzỉbu kā daudzdimensionālu parādību un iedzìvotāju priekšstati par mūsdienīgas dzives standartu. Pētījuma pirmajā kārtā tika noskaidroti iedzivotāju priekšstati par mūsdienīga brita ikdienas dzīves nepieciešamībām (piedāvājot plašu sarakstu ar lietām, pakalpojumiem un aktivitātēm, kas ietver visas dzīves dimensijas - sākot ar patērina precēm un pakalpojumiem, beidzot ar lídzdalïbu sabiedrības ekonomiskajā, sociālajā, politiskajā un kultūras dzīvē). Pētijuma otrajā kārtā tika noskaidrots, kuras lietas, pakalpojumi vai aktivitātes iedzivotājiem ir nepieciešami, bet to trūkst (Gordon et al., 2000). Tāāāk pētnieki skatīiās, pie kādiem ienākumu sliekšņiem iedzīvotāji sastopas ar būtiskiem ierobežojumiem dzīvot tādu dzīvi, kādu vairums uzskata par normu. Šãda pieeja lauj aplūkot ierobežojumu raksturu ievērojami niansētāk, nekā to ḷauj statistikā lietotā pieeja, un lauj analizēt, kā mājsaimniecību vajadzības saskaṇojas ar iespējām. 
SUSTINNO pētijumā pēckrīzes trajektoriju un iedzīvotāju dzives līmena analīzē ierobežoto līdzekḷu dẹḷ netika pilnībā atkārtota Gordona un kolēğu izstrādātā metodoloğija, tomēr iespēju robežās izmantots komplekss skatījums, kas, mūsuprāt, lauj precīzāk aplūkot mājsaimniecību vajadzību un iespēju attiecỉbas. Plašāk SUSTINNo pētỉjumā lietotā metodoloǵija aplūkota tam veltītajā apakšnodạ̣ā, bet vispirms tiks raksturotas sociālās problēmas Latvijā pēc ekonomiskās krīzes.

Pēckrīzes trajektorijas nabadzības un materiālās nenodrošinātības rādìtāi
Profesors Mihails Hazans rakstu par Latvijas darba tirgu krīzes laikā sāk ar vārdiem «Esam dziḷā bedrē un uz ilgu laiku» (Hazans, 2012, 254.lpp.). Kamēr daudzi tu krīzes pārvarēšanā (Oslunds \& Dombrovskis, 2012), tikmēr ne visas nozares atkopjas sekmigi (piemēram, veselības nozare, zinātne un augstākā izglìīiba), kā arī ne visi iedzīvotāji jūt ienākumu pieaugumu savos maciņos. Noteikti jāuzsver pozitiviais - 2015. gadā vairums Latvijas iedzīvotāju varēja atḷauties nodrošināt visas pamatvajadzības: ēdienu ( $81 \%$ var ațauties ēst gaḷu, zivis vai atbilstošu veǵetāru maltiti katru otro dienu), pajumti ( $83 \%$ nav bijuši parādi par īri, komunālajiem maksājumiem vai hipotekārā kredīta maksājumiem) un apơēerbu (64\% var atlauties novalkātās drēbes nomainìt pret jaunām, nevis no lietoto preču veikala). Vairumam mājsaimniecību ir pieejams telefons $(98 \%)$, televizors ( $97 \%$ ), velas mazgājamā mašina $(88 \%)$ un dators (68\%), pusei mājsaimniecību ir pieejama arī mašīna, un nedaudz vairāk kā puse mājsaimniecỉbu (58\%) pat var atḷauties katru gadu vienu nedēḷ doties brīvdienās ārpus mājām (Centrālā statistikas pārvalde, 2016). Salīdzinot rādītāju dinamiku kopš 2009. un 2010. gada, redzams, ka bezdarba rādītāji normalizējas (2010. gada pirmajā ceturksnī bezdarbs sasniedza pat $20 \%$, kamēr 2017. gada pirmajā ceturksnī-9\% (Hazans, 2012; Centrālā statistikas pārvalde, 2017c)), arī vidējā darba samaksa valstī lēnām kāpj pēc ekonomiskās krīzes (2010. gada pirmajā ceturksnì vidējā darba samaksa bija 620 eiro, kamēr 2017. gada pirmajā ceturksnī - 886 eiro (Centrālā statistikas pārvalde, 2017d) ). Lìdz ar to mājsaimniecību grūtības savilkt galus ar katru gadu patiešām klūst mazākas.

Tomēr ar vidējiem rādītājiem ienākumu un dzīves līmeṇa jautājumos ir tāpat kā ar gada vidējo temperatūru. Tāpat kā temperatūras svārstības mūsu klimata joslā dažādos gadalaikos ir būtiski atškirīgas, tā ienākumu un dzīves apstākḷu rādỉtāji dažādām sociālām grupām, kā arī reǵ̛ionālā griezumā ir būtiski atškiirīgi. Tāpēc tālāk pievērsīsimies reğionālajām un sociālo grupu atšķirībām, kuras lạuj spriest par to, kā virzāmies pretī vienlīdzīgām dzīves iespējām visā Latvijā un stabilam vidusslānim. Iesāksim arī diskusiju par pienācīgas dzives iespējām un nabadzỉbas un sociālās atstumtības riskiempārliecinošs vairākums iedzīvotāju var apmierināt savas pamata vajadzības (pēc pārtikas, mājokḷa un apgeēerba) un atḷauties tādas ilglietošanas preces kā televizors un telefons, taču situācija vairs nav tik laba, tikko jautājumi skar citas pienācīgai dzivei nepieciešamas preces, pakalpojumus un aktivitāšu daudzveidību. Piemēram, iespējas nomainìt nolietotās mēbeles, veikt mājokl̦a remontu, kad tas ir nepieciešams, vai aț̣auties apmeklēt ārstu un iegādāties ārsta izrakstîtās zāles. Kā parādīsim noslēdzošajā apakšnodalā, seviški satraucoša ir smagā preču, pakalpojumu un aktivitāšu deprivācija, kas aptver visas dzives jomas un ar ko sastopas iedzivotāji ar zemiem ienākumiem. Ja smagi apstākli skar atsevišķus cilvēkus, tad var runāt par individuāliem gadijumiem, ko raksturo nespēja uznemties atbildỉbu par savu dzivi un ǵimenes labklājibu. Ja vairāk nekā piektā dạ̣a sabiedrības sastopas ar smagiem apstākḷiem un ierobežotām iespējām visās dzìves jomās, tad tomēr jārunā par sistēmiskām problēmām sabiedrības līmenì. Patlaban situācija skaidri liecina, ka lỉdzšinējā sociālā politika, nodarbinātības politika, nodokḷu politika un veselības politika nedarbojas savstarpēji papildinoši un integrēti un nav spējušas efektivi aizsargāt un atbalstīt visơrūtākajā situācijā esošos Latvijas iedzìvotājus.

Iespējas nodrošināt pienācīgu dzìves līmeni un sociālā drošība sākas ar drošìbu darba tirgū un iespēju saṇemt cienīgu atalgojumu. Kaut gan strādājošo mēneša vidējā darba samaksa ir kāpusi kopš smagā darba algu līmena krituma, kas tika piedzìvots ekonomiskās krīzes laikā, saglabājas nozīmīgu reǵionālo atšķiiību tendence. Rīgā atalgojums ir ievērojami augstāks nekā citos reǵionos, turklāt Latgalē vidējā darba samaksa pat sešus gadus pēc krīzes ir zemāka nekā vidējā darba samaksa Rịgā krīzes laikā (sk. 1. tabulu). Atšḳirības starp pašvaldībām ar augstākajiem un zemākajiem vidējās darba samaksas rādītājiem ir vēl lielākas (Centrālā statistikas pārvalde, 2017e). 2016. gadā starp lielajām pilsētām aug̛stākā strādājošo mēneša vidējā darba samaksa (bruto/pavisam, bez privātā sektora komersantiem ar nodarbināto skaitu virs 50) bija Rīgā-1047 eiro, kamēr zemākā Daugavpilī - tikai 631 eiro Starp novadiem ar augstāko un zemāko mēneša vidējo darba samaksu (bruto/pavisam, bez privātā sektora komersantiem ar nodarbināto skaitu virs 50) atšķirība ir vairāk nekā divas reizes lielāka-Stopiṇu novadā 1091 eiro, kamēr Dundagas novadā vien 483 eiro. Tikai dažos novados ap Rīgu vidējā darba samaksa mēnesī ir virs 1000 eiro (nerēkinot vidējo darba algu, ko maksā vidējie un lielie komersanti), un darba samaksa paliek mazāka, attālinoties no Rīgas vai dažām lielajām pilsētām, tiesa, ar dažiem izṇēmumiem (tāds ir Jaunjelgavas novads, pateicoties diviem lieliem ražojošiem uznēmumiem). Pierigas plānošanas reǵiona statistiku «novelk» uz leju novadi, kas neatrodas Rīgas ietekmes areālā (piemēram, Alojas un Limbažu novads, kā arī Jaunpils un Kandavas novads ar vidējo darba samaksu mēnesī ap 650 eiro). Jāuzsver, ka vidējās darba samaksas rādītāii jāvērtē piesardzīgi. Kā intervijā «Latvijas 
1. tabula. Strādājošo mēneša vidējā darba samaksa

Latvijas regionos (bruto, EUR)

\begin{tabular}{lccccccc}
\hline Reǵions & 2010 & 2011 & 2012 & 2013 & 2014 & 2015 & 2016 \\
\hline Pavisam & 633 & 660 & 685 & 716 & 765 & 818 & 859 \\
\hline Riga & 724 & 757 & 778 & 815 & 869 & 925 & 971 \\
\hline Pieriga & 603 & 622 & 649 & 677 & 721 & 770 & 806 \\
\hline Vidzeme & 485 & 518 & 528 & 560 & 598 & 643 & 675 \\
\hline Kurzeme & 544 & 559 & 598 & 608 & 651 & 693 & 716 \\
\hline Zemgale & 508 & 547 & 571 & 597 & 645 & 683 & 725 \\
\hline Latgale & 440 & 468 & 475 & 490 & 522 & 564 & 592 \\
\hline
\end{tabular}

(Centrālā statistikas pārvalde, 2017f)

2. tabula. Nabadzības riska indekss Latvijas reǵionos

\begin{tabular}{lcccccc} 
Reğions & 2010 & 2011 & 2012 & 2013 & 2014 & 2015 \\
\hline Pavisam & 19,0 & 19,2 & 19,4 & 21,2 & 22,5 & 21,8 \\
\hline Rìga & 11,9 & 12,9 & 10,7 & 13,7 & 13,8 & 13,5 \\
\hline Pierīga & 15,3 & 15,5 & 17,3 & 19,6 & 17,5 & 18,6 \\
\hline Vidzeme & 23,5 & 27,8 & 30,7 & 26,8 & 28,2 & 29,2 \\
\hline Kurzeme & 20,4 & 19,8 & 19,6 & 21,2 & 22,9 & 21,7 \\
\hline Zemgale & 23,9 & 22,2 & 22,3 & 24,6 & 27,1 & 23,0 \\
\hline Latgale & 30,2 & 28,6 & 30,5 & 33,0 & 40,4 & 39,2 \\
\hline
\end{tabular}

(Centrālā statistikas pārvalde, 2016, 2017g)
Vēstneša» portālam norāda Centrālās statistikas pārvaldes Darba samaksas statistikas dalas vadītāja Lija Luste, tas ir makroekonomikas rāditājs. Iedzīvotāju dzīves līmeni un labklājību daudz precīzāk raksturo viṇu rīcībā esošie ienākumi uz mājsaimniecību vai iedzivotāju. Precīzāk tipisku vidējo algu raksturotu ienākumu mediānas aprēḳins, kurā galējās vērtības (ḷoti lielās un ḷoti mazās algas) netiktu ṇemtas vērā (Helmane, 2017).

Nākamais svarīgais rādītājs ir nabadzības riska indekss. Tā kā tas ir saistīts ar vidējiem ienākumiem valstī, pēckrīzes rādītāja trajektorija liecina par to, ka, augot vidējiem ienākumiem, šo kāpumu visi neizjūt vienādā mērā. Trūcīgāko iedzivotāju ienākumu kāpums atpaliek no labāk nodrošināto iedzìvotāju ienākumu kāpuma, tāpēc arī nabadzības riskam pakḷauto iedzivotāju ippatsvars visumā saglabājas vai pat nedaudz pieaug. Rādītājs, kam patiešām jāpievērš uzmanība, ir nozīmīgās atšķirības nabadzības riskam pakḷauto iedzīvotāju īpatsvarā reǵiionu griezumā (sk. 2.tabulu). Nabadzības riska indekss starp Rīgu un Latgali atškiras trīs reizes, un to nevar uzlūkot par pieņemamu rādītāju. Reğionālā griezumā vienīgi Rīgā nabadzības rādītāji ir zem vidējiem Eiropas Savienībā, kas 2015. gadā bija 17,3\% (Eurostat, 2016).

Sociāli mazāk aizsargāto iedzīvotāju iespējas sanemt atbalstu arī vērtējamas kritiski. Pastāv būtiskas atšķirības gan lielo pilsētu un pārējo pašvaldỉbu griezumā, gan arī starp pašvaldībām. Analizējot Labklājības ministrijas datus par pašvaldỉbu izdevumiem sociālajai palīdzỉbai, jāuzsver, ka pilsētās uz mazāku skaitu trūcīgu personu ir pieejams nozimīgi lielāks finansējums. Līdzịga aina vērojama arī attiecībā uz visiem pašvaldību sociālās palīdzības izdevumiem kopā. Piemēram, 2015. gadā devinās lielajās pilsētās 80334 personas sanēma sociālo palīdzību 22157459 eiro apmērā, kamēr pārējos 110 novados kopā 106455 personas saṇēma tikai 16378255 eiro lielu palīdzỉbu (Labklājibas ministrijas, 2016). Pastāv arī ievērojamas atšķirīibas starp pašvaldību budžeta izdevumiem sociālajam atbalstam uz vienu iedzivotāju. Atbilstoši Reğionālās attīstības indikatoru modulī (RAIM) pieejamiem aprēḳiniem 2016. gadā divas dāsnākās pašvaldỉbas sociāāā atbalsta ziṇā uz vienu iedzīvotāju bija Aknisstes novads (57,0o eiro) un Alojas novads ( 62,85 eiro), savukārt divas skopākās - Tērvetes novads (9,30 eiro) un Apes novads (6,40 eiro) (RAIM, 2017). N̦emot vērā ienākumu rādītājus, nodarbinātỉbas rādìtājus, iedzīvotāju skaitu un pensijas vecuma iedzivotāju îpatsvaru minētajās pašvaldībās, tās ir samērā līdzịgas, tāpēc bez dzilākas gadijumu izpētes atškirības nav izskaidrojamas un noteikti nav pamata domāt, ka šo pašvaldību mazāk sociāli aizsargāto iedzīvotāju vajadzības tik nozimīgi atškirirtos.

Šis piemērs spilgti izgaismo problēmu, kas raksturīga arī citām pašvaldībām - iedzivvotājiem pieejamā sociālā palīdzība un pakalpojumi nav tik daudz saistīti ar viṇu vajadzībām, cik ar pašvaldības pieeju sociālā atbalsta nodrošināšanā. Arī pašvaldỉbu noteiktie ienākumu sliekšni maznodrošinātā statusa iegūšanai ir loti dažādi. Piemēram, 2015. gadā dažās pašvaldībās tas ir 
3. tabula. Ekonomiskā spriedze mājsaimniecībās (\%)

\begin{tabular}{lcccccc}
\hline Reǵions & 2010 & 2011 & 2012 & 2013 & 2014 & 2015 \\
\hline Pavisam & 66,3 & 68,9 & 65,7 & 58,3 & 53,0 & 47,1 \\
\hline Riga & 61,6 & 59,7 & 57,9 & 51,5 & 45,6 & 38,9 \\
\hline Pierīga & 69,6 & 74,7 & 67,9 & 56,3 & 56,3 & 49,6 \\
\hline Vidzeme & 70,6 & 78,3 & 70,0 & 69,3 & 61,5 & 54,1 \\
\hline Kurzeme & 65,5 & 70,4 & 67,3 & 63,6 & 51,1 & 46,4 \\
\hline Zemgale & 68,0 & 67,5 & 68,0 & 63,1 & 57,5 & 52,7 \\
\hline Latgale & 70,0 & 76,8 & 74,8 & 61,0 & 58,5 & 54,5 \\
\hline
\end{tabular}

(Centrālā statistikas pārvalde, 2017f)

tikai nedaudz virs valstī vienotā trūcīgas personas statusa iegūšanai noteiktā ienākumu sliekšṇa, kas ir 128,06 eiro, citās pašvaldỉbās maznodrošinātas personas ienākumu slieksnis pārsniedza trūcīgas personas ienākumu slieksni trīs reizes. Piemēram, Rīgā ienākumu līmenis, kāds noteikts maznodrošinātai ǵimenei (personai), bija 400 eiro, bet Jūrmalā, kas atrodas netālu no Rìgas, - tikai 178 eiro (Labklājības ministrijas, 2016). Varam pieṇemt, ka vidèjā darba samaksa un dzives dārdzība Rīgã un Jūrmalā loti būtiski neatškiras, un sociālās problēmas, ar kurām sastopas iedzivvotāji, varētu būt samērā līdzīgas. Tomēr Rīga sociālajam atbalstam atvēl 42,28 eiro uz iedzìvotāju, kamēr Jūrmala-26,34 eiro (RAIM, 2017). Šie piemēri parāda, ka, cienot pašvaldību autonomiju, tomēr ir nepieciešami vienoti nosacijjumi sociālā atbalsta sniegšanai pašvaldībās (dzilāk neaplūkosim citus kritērijus un atšķirības pieejamās palīdzības un pakalpojumu grozā). Pretējā gadijjumā problēma, uz kuru Labklājības ministrija norādỉjusi jau iepriekš, proti, ka cilvēkiem līdzịgās problēmsituācijās atkarībā no dzīvesvietas ir pieejams atšḳirìgs palīdzības un pakalpojumu grozs (Labklājibas ministrija, 2014b),-tikai turpināsies. LIAS 2030 un «Latvijas Nacionālajā attīstības plānā 2014.-202O.gadam» (NAP 2020) izvirzītie mērḳi par reǵionālo atšķirību izlīdzināšanu un līdzvērtīgu dzìves iespēju nodrošināšanu visā Latvijas teritorijā nav îstenojami kaut vai tâpēc vien, ka sociāli mazāk aizsargātie iedzivvotāji patlaban nevar pat cerēt uz līdzīgu atbalstu līdzīgās situācijās.
Tomēr viens no ticamākajiem rādītājiem, kas vistiešāk raksturo dzives līmeni, kādu iedzīvotāji var atḷauties ar tiem ienākumiem, kas ir viṇu rīcībā, ir mājsaimniecību ekonomiskās spriedzes indekss. Šo indeksu aprēḳina ar vairāku jautājumu palīdzību, kuros respondentiem jānovērtē mājsaimniecības spēja segt izmaksas piecās jomās:

segt komunālos maksājumus, îri un kredītu (t. sk. līzinga maksājumus par pirkumiem uz kredīta); uzturēt mājokli siltu; atlauties segt neparedzētus izdevumus no pašu lïdzekḷiem; ēst gạu, putnu gaḷu vai zivis, vai lïdzvērtīgu veğetāro maltiti katru otro dienu; katru gadu vienu nedẹlu doties brìvdienās ārpus mājām. Mājsaimniecỉbas, kuras vismaz uz diviem jautājumiem sniedz noraidošu atbildi, tiek uzskatītas par paklautām ekonomiskajai spriedze (Centrālā statistikas pārvalde, 2015).

Minētos ikdienas izdevumus var uzlūkot kā Eiropā pienemta pienācīga dzīves standarta minimumu, jo līdzās pamatvajadzībām tiek mērītas arì iespējas segt neparedzētus izdevumus, parasti neto minimālās mēnešalgas apmērā, un apcelot kaut vai dzimto zemi (aptaujā nav norādīts, vai domāts ceḷojums uz ārzemēm vai nedēḷu ilğs ceḷojums savā zemē). Kaut arī pēc ekonomiskās krīzes ekonomiskās spriedzes rādìtāji ievērojami uzlabojas ar katru gadu, tomēr tie labi parāda, ka iedzīvotāju ienākumi pret pienācīga dzìves standarta izmaksām joprojām ir pieticīgi, kā arī Rỉgas rādītāji ir ievērojam labāki nekā citos reǵ̛ionos (sk. 3. tabulu).

Vairāk nekā trešā dala rīdzinieku, gandrīz puse Kurzemes un Pierīgas iedzīvotāju, bet Vidzemē, Zemgalē un Latgalē vairāk nekā puse iedzivotāju joprojām sastopas ar ekonomisko spriedzi-tātad viṇu ienākumi neḷauj segt Eiropā pieṇemta pienācīga dzives standarta minimumu. Ja raugāmies uz LIAS 2030 un NAP 2020 izvirzitajiem mērkiem vidusškiras stiprināšanai, tad varam apgalvot, ka tur, kur ir ekonomiskā spriedze, nav vidusškiras.

Nenodrošinātības noteikšanas metodologija: no ienākumiem uz vajadzību apmierināšanu

Tradicionālās metodes labklājỉbas vai trūciguma lìmeṇa mērīšanai apsekojumos balstās uz ienākumu līmena noteik-

šanu: parasti mājsaimniecībai, retāk pašai personai, kura tiek aptaujāta. Kaut gan šai pieejai ir šḳietami universāls raksturs, tai ir nopietni ierobežojumi. Pirmais un būtiskākais ir tas, ka tā nesniedz pilnīgu informāciju par cilvēka un mājsaimniecības izdevumu struktūru un vajadzībām, arī nemot vērā ienākumus uz katru mājsaimniecības locekli. Lai arī visiem cilvēkiem parast jāiegādājas pārtika, jānosedz komunālie maksājumi, jānorēkininās par medicīniskiem pakalpojumiem un zālēm, laiku pa laikam jāatjauno apgoēèbs un 
mēbeles utt., šie izdevumi var būt krasi atšķirīgi atkarībā no respondenta un/vai mājsaimniecības konkrētiem dzīves apstākḷiem un vajadzībām. Otrais iemesls ir tas, ka aptaujās cilvēki bieži vien nelabprāt atklāj savus vai savas mājsaimniecības ienākumus vai nenorāda tos loti precīzi, turklāt neatbildētības līmeni jautājumiem par ienākumiem var sasniegt 25-30\%. Šis apstāklis acīmredzami mazina ienākumu kā labklājības un nabadzības rādītāja ticamỉbu. Piemēram, SUST INNO aptaujā 29,5\% respondentu nesniedza atbildi uz jautājumu par mājsaimniecības ienākumiem.

Cita pieeja, kuru pārstāv, piemēram, starptautiski izmantotais materiālās nenodrošinātības indekss, nabadzịgo personu īpatsvaru raksturo, ņemot vērā tādu personu īpatsvaru, kurām ir grūtības iegādāties noteiktas preces vai pakalpojumus, kā arī segt noteiktas izmaksas (sk. 111.lpp.). Lai gan šì pieeja fokusējas uz izdevumu struktūru un tādējādi ir būtisks solis uz priekšu salīdzinājumā ar ienākumu kā nodrošinātỉbas rādītāja izmantošanu, arì tai piemit noteikti ierobežojumi. Piemēram, ne visiem ir nepieciešams lietot vai turēt īpašumā vieglo automašinu; tas pats sakāms par krāsu televizoru, kuru daudziem cilvēkiem arvien biežāk nomaina dators ar interneta pieslēgumu. Strïdīga izskatās arī komunālo maksājumu un kredītu iekḷaušana vienā kategorijā, jo nepieciešamība segt komunālos maksājumus ir krietni izplatītāka nekā kredītu maksājumu segšana, turklāt kredītsaistību apjoms un slogs var būtiski atškirties pēc aizdevuma summas, kā arī atmaksāšanas termina, grafika un citiem nosacỉjumiem. Šajā indeksā nav iekḷautas arī tādas pozīcijas kā jaunu apg̣ērbu un apavu iegāde, nolietoto mēbeḷu nomainīšana un remonta veikšana mājoklī - tie ir būtiski dzìves kvalitātes rādītāji.

Šajā rakstā tiek piedāvāta alternatīva pieeja nabadzības un sociālās atstumtības kvantitativai mērišanai. Šim nolūkam izmantots SUSTINNO 2015. gada «Pētījuma par nabadzības un sociālās atstumtības riskiem» instrumentārijs (aptaujas anketa) un aptaujas dati. Pētijums tika veltīts dažādu

4. tabula. Vidējie ienākumi dažādos deprivācijas līmeṇos

\begin{tabular}{llllllllllll}
\hline $\begin{array}{l}\text { Lietu skaits, ko mājsaimniecíba } \\
\text { var ațauties }\end{array}$ & & 0 & 1 & 2 & 3 & 4 & 5 & 6 & 7 & 8 \\
\hline $\begin{array}{l}\text { Grupai piederīgo } \\
\text { respondentu skaits }\end{array}$ & Kopā: & 1414 & 32 & 72 & 100 & 146 & 155 & 169 & 154 & 217 & 369 \\
\hline $\begin{array}{l}\text { Vidējie ienākumi uz 1 mājsaim- } \\
\text { niecibas locekli grupā, EUR* }\end{array}$ & $\begin{array}{l}\text { Vid.: } \\
329\end{array}$ & 193 & 182 & 211 & 263 & 279 & 318 & 360 & 373 & 415 \\
\hline
\end{tabular}

* Ērtibas labad noapaḷots lídz veseliem eiro. dzives apstāklu un dzives kvalitātes aspektu izzināšanai un aptvēra reprezentatīvu Latvijas iedzīvotāju izlasi $(n=2007)$.

Kā pārticības un nabadzības pamatrādītājs tiks aplūkotas respondentu atbildes uz virkni dihotomisko ( «ijā/nē» formāta) jautājumu par to, vai visa vinu mājsaimniecība (neatkarīgi no cilvēku skaita) var atlauties izdevumus noteiktās jomās, kas aptver atpūtu, uzturu, mājokli, mājokḷa iekārtu un stāvokli, apgèērbu, sociālos kontaktus un komunikācijas tehniskās iespējas:

1) katru gadu vienu nedēḷu doties brīvdienās ārpus mājām (neieskaitot palikšanu citā mājoklī (dārza mājā, vasarnīcā) vai pie draugiem/radiniekiem);

2) ēst galu, putnu galu vai zivis (vai lídzvērtīgu veğetāro ēdienu) katru otro dienu;

3) uzturēt mājokli pietiekami siltu;

4) nomainit nolietotās mēbeles;

5) veikt dzivokḷa remontu, kad tas ir nepieciešams;

6) iegādāties jaunas drēbes (ne no lietotu preču veikala);

7) reizi mēnesī uzaicināt radus vai draugus uz pusdienām;

8) izmantot interneta pieslēgumu.

Summējot katra indivīda atbildes uz šiem astoṇiem jautājumiem, ir veidojama summētā rangu skala (Spector, 1992), kuras rangi iekḷauj vērtỉbas no o (nevar atlauties neko no saraksta) lídz 8 (var atlauties visu no saraksta) Šie rangi parāda dažādus deprivācijas līmeṇus (jo zemāks ir rangs, jo deprivētāka, proti, trūcīgāka, ir mājsaimniecỉba). Tai pašā laikā jāatzīst, ka šì skala vēl nesniedz priekšstatu par deprivāciju lìmenu savstarpējām atškirībām cik daudz lietu no saraksta būtu jāspēj atḷauties mājsaimniecībai, lai (ne) uzskatītu to par deprivētu. Lai iezīmētu deprivācijas sliekšņus, jāatgriežas pie mājsaimniecības ienākumu līmena, kas iepriekš minētās augstās neatbildētības dēl netiks izmantots kā pārticības un nabadzības rādītājs, taču to var izmantot kā ilustratīvu kritēriju deprivācijas līmeṇu noteikšanai. Runa ir par mājsaimniecības ienākumu vidējo vērtỉbu salīdzināšanu un to atšķirību statistiskā nozīmīguma izvērtēšanu.

Izkliedes analīzes rezultāti sniedz priekšstatu par katram deprivācijas līmenim atbilstošās grupas vidējiem ienākumiem (sk. 4. tabulu). Jāṇem vērā, ka no 2007 aptaujas respondentiem saturiskās atbildes par savu ienākumu līmeni sniedza 1414 jeb 70\% respondentu. Kopumā atšķirības grupu starpā ir statistiski nozīmìgas $(F=32,77 ; p<0,05)$, taču tas vēl nerāda, vai atškirìibu nozìmỉgums ir spēkā katrai grupai salīdzinājumā ar visām pārējām. Lai to pārbaudìtu, nepieciešams veikt izkliedes analīzes pēcanalizzes testus (post-hoc tests; viens no biežāk lietotajiem ir Bonferoni pēcanalīzes tests). 5. tabula atspogulo, cik lielas atškiirības ienākumos (eiro) ir katrai mājsaimniecībai no visām pārējām, kā arī statistiskā nozīmīguma līmenus katrai atškirỉbai. Piemēram, 
5. tabula. Izkliedes analīze: Bonferoni pēcanalīzes testu rezultāti*

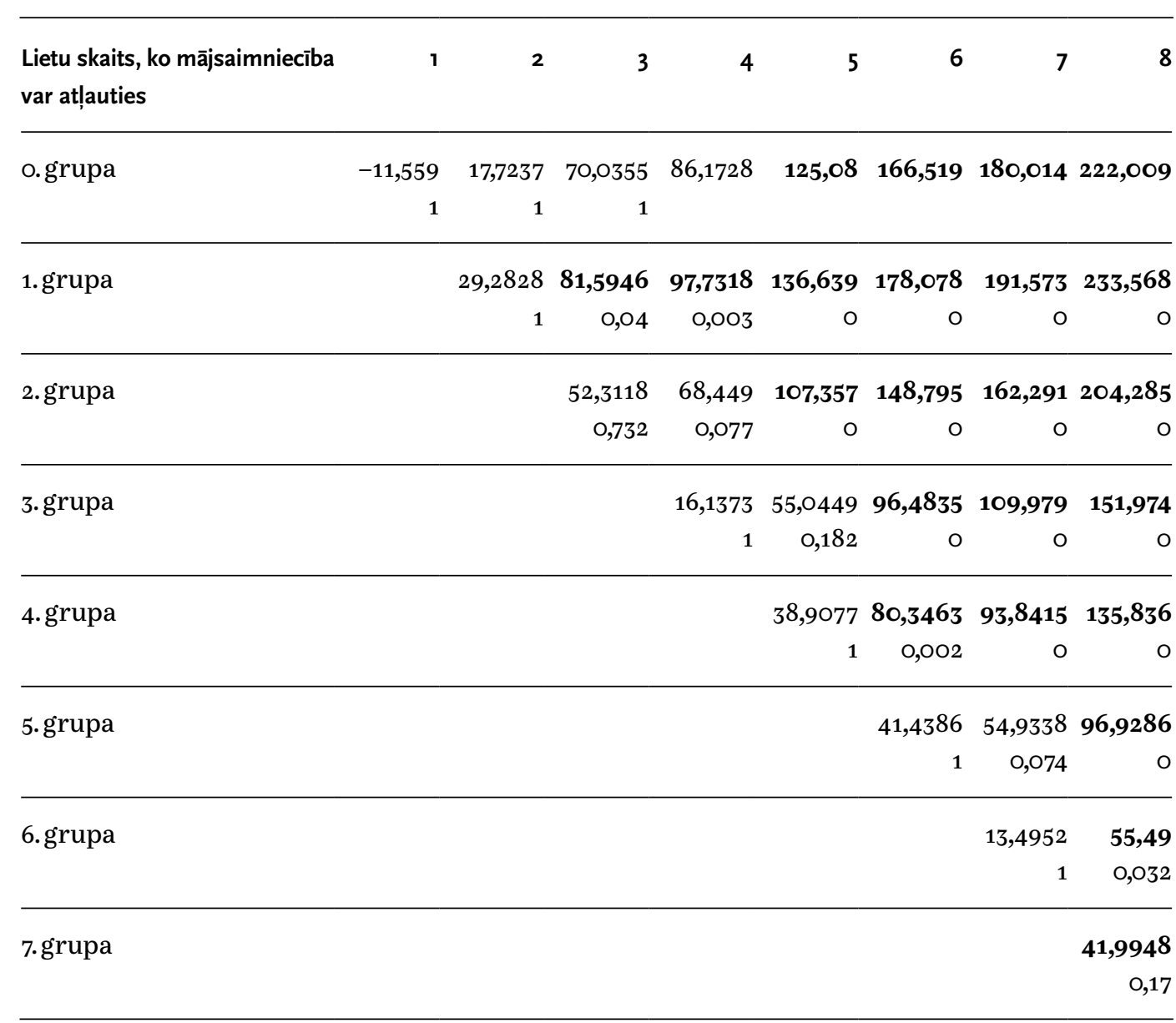

* Statistiski nozimīgi rezultāti izcelti treknrakstā.

iedzīvotāju grupa, kas nevar ațauties tēriṇus nevienā no jomām, vidēji saṇem par 11,56 eiro mazāk nekā grupa, kas var aț̣auties tēriṇus kādā vienā jomā, taču šis atškirïbas nav statistiski nozīmiggas. Tai pašā laikā 6. grupa ir par 80,34 eiro pārticìgāka nekā 4. grupa un šīs atšķiiības ir statistiski nozimīgas $(p=0,002)$.

No 5. tabulas ir secināms, ka ne visiem iespējamiem grupu pāriem ir statistiski nozimìgas atšķirības. Zìmīgi ir o., 1. un 2. grupas gadijumi (respektīvi, 193, 182 un 211 eiro apmērā, turklāt 1. grupas vidējie mājsaimniecības ienākumi uz vienu locekli ir nedaudz zemāki nekā visdeprivētākajai o. kategorijai). Šìs grupas ir loğiski apvienot vienā, uzskatot tās sociālekonomisko situāciju par nelabvēlīgāko.

6. tabula. Grupu apvienojums piecu deprivācijas līmeṇu kategorijās

\begin{tabular}{ll}
\hline Kategorijas & Grupas \\
\hline Pirmā (mājsaimniecība nevar aț̣auties 6-8 lietas no saraksta) & 0., 1., 2. \\
\hline Otrā (nevar atḷauties 4-5 lietas no saraksta) & $3 ., 4$. \\
\hline Trešā (nevar atḷauties 3 lietas no saraksta) & 5. \\
\hline Ceturtā (nevar aț̣auties 1-2 lietas no saraksta) & $6 ., 7$. \\
\hline Piektā (var aț̣auties visu no saraksta) & 8. \\
\hline
\end{tabular}

Nākamās iespējamās kandidātes uz apvienošanu ir 3. un 4.grupa ar vidējiem mēneša ienākumiem 263 un 279 eiro uz vienu mājsaimniecības locekli. To starpā nav statistiski nozīmīgu atšḳirību, tai pašā laikā 3. un 4. grupa nozimīgi atšķiras no 6., 7. un 8. grupas. Naudas izteiksmē tās atrodas tālu no 5. grupas, kuras vidējie ienākumi ir 318 eiro, tāpēc 3. un 4. grupa apvienojamas nākamajā līmenī, kas arī uzskatāms par nelabvēlīgu, lai gan mazākā mērā nekā o., 1. un 2. grupu aptverošais.

5. grupai ir statistiski nozīmīgas atškiriibas no 6., 7. un 8. grupas, kā arī ienākumu rādītājs (318 eiro) ir vistuvāk vidējai vērtỉbai (329 eiro). Tā apvieno mājsaimniecības, kas var aț̣auties tēriṇus piecās no astoṇām jomām, un tas ir vērtējams kā vidējs labklājības (vai arī deprivācijas) līmenis. 6. un 7.grupa atbilst mājsaimniecībām, kas nevar atlauties tērinus divās vai vienā no astoņām jomām, un ir apvienojamas vidēji augstā labklājības līmeṇa grupā. Visbeidzot, piekto un vislabāk situēto kategoriju veido 8.grupa, kurai piederīgie var atlauties tērinus visās astoṇās jomās. Kategoriju pärskats attēlots 6 .tabula.

Nabadzības un materiālās nenodrošinātības faktori: empīiskās liecības
Respondentu mājsaimniecību materiālās nenodrošinātības analīzē pirmā būtiskā atziṇa ir tā, ka deprivācijas rādītāji atšḳiras ne tikai respondentu grupu, bet arì dažādu jomu starpā. Piemēram, gandrīz visi respondenti norāda, ka var atlauties uzturēt mājokli pietiekami siltu, tai pašā laikā veikt remontu, kad tas ir nepieciešams, var atḷauties mazāk nekā puse respondentu. Runājot par izmaksām sociālo kontaktu uzturēšanai, $23 \%$ jeb nedaudz mazāk kā viena ceturtā dal mājsaimniecību nevar atlauties kaut reizi mēnesī uzaicināt radus vai draugus 
7. tabula. Mājsaimniecību îpatsvars, kas var aț̣uties segt izmaksas noteiktās jomās (sk. sarakstu 119.lpp)

\begin{tabular}{|c|c|c|c|}
\hline \multicolumn{2}{|c|}{ Indikatori } & \multicolumn{2}{|l|}{ Īpatsvars } \\
\hline 1. & $\begin{array}{l}\text { Katru gadu vienu nedēḷu doties brīvdienās } \\
\text { ārpus mājām }\end{array}$ & |||||||||||||||||||||||||||||||| $\mid$ & $46 \%$ \\
\hline 2. & $\begin{array}{l}\text { Ēst galu, putnu galu, zivis vai līdzvērtīgu } \\
\text { veğetāro ēdienu katru otro dienu }\end{array}$ & |||||||||||||||||||||||||||||||||||||||||||||||||||||||| & $82 \%$ \\
\hline 3. & Uzturēt mājokli pietiekami siltu & |||||||||||||||||||||||||||||||||||||||||||||||||||||||||||||||||||||| & $95 \%$ \\
\hline 4. & Nomainìt nolietotās mēbeles & ||||||||||||||||||||||||||||||| & $45 \%$ \\
\hline 5. & $\begin{array}{l}\text { Veikt dzivokla remontu, kad tas } \\
\text { ir nepieciešams }\end{array}$ & |||||||||||||||||||||||||||||| $\mid$ & \\
\hline 6. & Iegādāties jaunas drēbes & 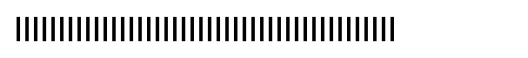 & $71 \%$ \\
\hline 7. & $\begin{array}{l}\text { Reizi mēnesī uzaicināt radus vai draugus } \\
\text { uz pusdienām }\end{array}$ & |||||||||||||||||||||||||||||||||||||||||||||||||||||| & \\
\hline 8. & Interneta pieslēgums & 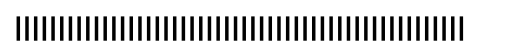 & $84 \%$ \\
\hline
\end{tabular}

uz pusdienām. Nolietoto mēbeḷ nomainīšana arī ir problemātiska vairāk nekā pusei mājsaimniecỉbu - to var aț̣auties vien $45 \%$ respondentu (7.tabula).

Kopumā materiālās nenodrošinātības un deprivācijas rādītājos iezīmējas būtiskas kvalitatīvas atškirības. Trīs jomas, kurās ir lielākais deprivācijas risks, ir saistitas ar mājas iekārtošanu un remontēšanu, kā arī došanos ārpus mājām, piemēram, atvaḷinājumā - šis lietas var aț̣auties mazāk nekā puse mājsaimniecību. Otrā jomu grupa, kur deprivācijas rādītāji ir krietni zemāki, apvieno jauna apgeērba iegādāšanos un sociālo kontaktu uzturēšanu - atrast resursus šo vajadzību apmierināšanai rada problēmas aptuveni $1 / 4$ mājsaimniecību. Samērā laba situācija ir ar uzturu un interneta pieslēgumu, kas mūsdienās acimredzot ir kḷuvis par pārliecinošu dzives pamata vajadzibu deprivēto skaits šajās jomās ir zem $20 \%$, lai arì tas nav maz. Visbeidzot, pārliecinošs vairākums mājsaimniecību (95\%) spēj uzturēt mājokli pietiekami siltu. Lïdz ar to nākamais jautājums, kas izriet no ḷti neviendabịgas vajadzību apmierinātspējas, ir tas, cik dažādu vajadzību apmierināšana korelē savā
8. tabula. Deprivācijas indikatoru korelācijas (sk. sarakstu 119.lpp)

\begin{tabular}{|c|c|c|c|c|c|c|c|c|c|}
\hline Indikatori & & 1. & 2. & 3. & 4. & 5. & 6. & 7. & 8. \\
\hline & 1. & 1 & & & & & & & \\
\hline & 2. & 0,3342 & 1 & & & & & & \\
\hline & 3. & 0,1688 & 0,3018 & 1 & & & & & \\
\hline & 4. & 0,4936 & 0,3385 & 0,1683 & 1 & & & & \\
\hline & 5. & 0,4354 & 0,3289 & o,1639 & 0,7017 & 1 & & & \\
\hline & 6. & 0,4018 & 0,4332 & 0,2043 & 0,4817 & 0,4163 & 1 & & \\
\hline & 7. & 0,3715 & 0,4073 & 0,2464 & 0,3919 & 0,3665 & 0,4741 & 1 & \\
\hline & 8. & 0,3057 & 0,3906 & 0,2341 & 0,287 & 0,2684 & 0,4216 & 0,3264 & 1 \\
\hline
\end{tabular}

Piezime: visi koeficienti ir statistiski nozīmiggi vismaz $p=0,05$ lïmenī. Stiprākās korelācijas izceltas treknrakstā.

starpā un vai tiešām var runāt par dažādu vajadzību «klasteriem» atkarībā no tā, cik liels vai mazs mājsaimniecibu ippatsvars var segt to apmierināšanas izmaksas. Dzị̣āku ieskatu šajā jautājumā spēj sniegt korelāciju analīze, kurai tiks izmantots neparametriskais Spïrmena korelācijas koeficients, nemot vērā indikatoru dihotomisko dabu (8. tabula).

No deprivācijas indikatoru korelācijas ir redzams, ka visciešāk savā starpā korelē 4. un 5.indikators, proti, nolietoto mēbeḷ nomainišana un mājokḷa remonta veikšana. Nākamie stiprākie koeficienti ir nolietoto mēbeḷ nomainišanai un brīvdienu pavadišanai ārpus mājām $(0,49)$, un jaunu drēbju iegādei (o,48). Visvājāk savā starpā korelē 3.indikators (uzturēt mājokli pietiekami siltu) ar 4. un 5.indikatoru -zimīgi, ka tie arī attiecas uz mājokla uzturēšanu. Acīmredzot regulāras iemaksas par siltuma uzturēšanu mājsaimniecībām grūtības nesagādā (to var atlauties 95\%), atškiirībā no neregulāriem, toties būtiskiem tēriniem atvalinājumam ārpus mājām un par mēbelu nomainu.

Nākamais solis ir aplūkot divdimensionālas sakarības deprivācijas līmenī, kurā iekḷaujas svarīgākie sociāldemogrāfiskie mainīgie-dzimums, nodarbinātība, bērnu skaits mājsaimniecībā, izglìtîbas līmenis un reğions, kurā atrodas respondenta mājsaimniecības dzivesvieta. Šo mainīgo klāstā 
9. tabula. Respondentu spējas segt izmaksas noteiktās jomās pēc izglïtības lìmeṇa

\begin{tabular}{|c|c|c|c|}
\hline Izglitīibas lìmenis & $\begin{array}{l}\text { Respondentu } \\
\text { ipatsvars*, \% }\end{array}$ & $\begin{array}{r}\text { Labumu skaits, } \\
\text { ko mājsaimniecība } \\
\text { var aț̣auties (vid.) }\end{array}$ & $\begin{array}{r}\text { Drošticamības } \\
\text { intervāls }\end{array}$ \\
\hline Pamata (8-9 klases) & 7,7 & 4,4 & $3,98-4,82$ \\
\hline Nepabeigta vidējā & 4,5 & 5,4 & $4,96-5,87$ \\
\hline $\begin{array}{l}\text { Arodizglītība (arodskola } \\
\text { bez vidējās izglīitibas) }\end{array}$ & 4,6 & 4,0 & $3,52-4,53$ \\
\hline $\begin{array}{l}\text { Vidējā vispārizglïtojošā } \\
\text { (11-12 klases) }\end{array}$ & 15,7 & 5,2 & $4,97-5,46$ \\
\hline Vidējā profesionālā/speciālā & 32,1 & 5,2 & $5,00-5,35$ \\
\hline Nepabeigta augstākā & 8,2 & 6,1 & $5,79-6,38$ \\
\hline Augstākā & 25,4 & 6,3 & $6,11-6,42$ \\
\hline Zinātniskais grāds & 1,7 & 6,9 & $6,43-7,46$ \\
\hline
\end{tabular}

* Noapaḷts līdz desmitdaḷām.

var iekḷaut arī ienākumus, taču analīzes rezultāti interpretējami piesardzīgi, ṇemot vērā augstu neatbildētību uz jautājumu par ienākumiem.

Deprivācijas lìmena atšḳirības abiem dzimumiem ir nozimingas statistiski $(p=0,02)$, bet ne saturiski. Piemēram, pie 1. (deprivētākās) kategorijas, kura nevar ațauties $6-8$ lietas, pieder $11,7 \%$ viriešu un $12,4 \%$ sieviešu, pie 3. kategorijas $-13,4 \%$ viriešu un $14,1 \%$ sieviešu, bet pie 4 . kategorijas $-26 \%$ vīriešu un $26 \%$ sieviešu. Dzimumu atškirības ir ievērojamākas 2. jeb otrajā nabadzīgākajā kategorijā, kurā ir sieviešu pārsvars (pie tās pieder 23,1\% sieviešu un $18,7 \%$ vīriešu) un 5 . jeb vislabāk situētajā kategorijā, kurā savukārt ir vīriešu pārsvars (30,3\% vïriešu un 24,3\% sieviešu). Jāsecina, ka dzimums nav starp galvenajiem nabadzibu veicinošiem faktoriem.

Nodarbinātības sakarība ar deprivācijas lïmeni ir gan saturiski, gan statistiski nozimiga $\left(\chi^{2}=137,4 ; p<0,001\right)$, un datos redzamā aina atbilst sagaidāmajai atzinai - strādājošie retāk ieslīgst nabadzībā nekā nestrādājošie.
Piemēram, pie deprivētākās kategorijas pieder 6,8\% strādājošo un 20,9\% nestrādājošo, pie otras nabadzīgākās kategorijas - 17,9\% un 26,6\%. Atlikušajās kategorijās, kas atbilst labvēlīgākai sociālekonomiskai situācijai, vērojams strādājošo respondentu pārsvars, lai arī ne tik izteikts kā nestrādājošo prevalence 1. kategorijā. Piemēram, to respondentu vidū, kas norāda, ka var aț̣auties tēriṇus visās astoṇās jomās, ir 32,2\% visu strādājošo respondentu un $18,2 \%$ visu nestrādājošo.

Izglìtības lïmenis tradicionāli tiek uzskatīts par tikpat svarīgu sociālekonomiskās nodrošinātības faktoru kā nodarbinātība, un abi šie faktori ir cieši saistīti viens ar otru. SUSTINNO pētijumā tiek izcelti astoṇi izglītibas līmeni. Jāatzīmē, ka respondentu sadalijjums pēc izglìīibas līmeniem ir loti nevienmērīgs - ar vidējās profesionālās/speciālās (32,1\%) un augstākās $(25,4 \%)$ izglìtības līmeṇu pārsvaru un nelielu respondentu īpatsvaru zemāko izglītỉbas līmenu kategorijās. Spirmena rangu korelācijas koeficienta vērtība izglìtības limena un deprivācijas līmena sakarỉbai ir o,25 ar statistisko nozīmīgumu $p<0,005$. Kopumā tas liecina par sociālekonomiskās situācijas uzlabošanos, pieaugot izglìtības līmenim. Lai uzskatāmāk attēlotu izglìtỉbas limena un deprivācijas lìmena sakarību, atgriezisimies pie astonu labumu saraksta un salīdzināsim, vidēji cik daudz dažādu labumu var atḷauties respondenti atkarībā no izglìtỉbas līmeṇa (9. tabula).

No tabulas redzams, ka pirmo triju izglìtỉbas līmenu pārstāvji vidēji var atlauties 4-5 labumus no saraksta, respondenti ar vidējo vispārējo vai vidējo profesionālo/speciālo izglìtību -5 labumus, savukārt personas ar nepabeigtu un pabeigtu augstāko izglītỉbu - vidēji 6-7 labumus. Nemot vērā drošticamības intervālu pārklāšanos (pamatizolìtība, nepabeigta vidējā izglìtība un arodizglīiiba), redzams, ko šo triju grupu starpā nav statistiski nozīmīgu atškiirību. Zìmīgi, ka nepabeigtās vidējās izglìtỉbas grupas pārstāvjiem vidējā labumu skaita drošticamības intervāls pārklājas ar diviem salïdzinoši augstākiem līmeniem - vidējo vispārizglìtojošo un vidējo profesionālo/speciālo izglìitibu. Tai pašā laikā jāpievērš uzmanība tam, ka nepabeigtās vidējās izglìtības grupas pārstāvju ir ḷoti maz (91 respondents jeb $4,5 \%$ no izlases), tās stāvoklis nav izplatîts vai tipisks (pārtrauktās izglìtības dēḷ), un šo iemeslu dēl to nevar uztvert kā viendabīgu grupu ar labi paredzamām nodarbinātības un labklājības izredzēm. Iespējams, ka šīs grupas izpēte prasītu lielāku iedzilināšanos individuālajās dzīves gaitās ar kvalitatìvo pētniecības metožu palìdzỉbu.

Vēl viens faktors, kas potenciāli var ietekmēt mājsaimniecības spējas atlauties noteiktus labumus, ir nepilngadīgo bērnu skaits ğimenē. No pirmā skatiena būtu loğiski pieṇemt, ka nepieciešamỉba gādāt par nepilngadīgiem bērniem ir izaicinājums mājsaimniecību sociālekonomiskajai situācijai, lĩdz ar to var sagaidīt, ka mājsaimniecības bez nepilngadīgiem bērniem būs salīdzinoši labklājīgākas. Lai šo pienēmumu pārbaudītu, salīdzināsim, cik vidēji 
10. tabula. Respondentu spējas segt izmaksas noteiktās jomās pēc nepilngadīgo bērnu skaita mājsaimniecībā

\begin{tabular}{lrr}
$\begin{array}{l}\text { Nepilngadīgo bērnu skaits } \\
\text { mājsaimniecībā }\end{array}$ & $\begin{array}{r}\text { Labumu skaits, ko } \\
\text { mājsaimniecība } \\
\text { var ațlauties (vid.) }\end{array}$ & $\begin{array}{r}\text { Drošticamības } \\
\text { intervāls }\end{array}$ \\
\hline Neviens & 5,3 & $5,17-5,41$ \\
\hline 1 & 5,9 & $5,73-6,15$ \\
\hline 2 un vairāk & 5,8 & $5,50-6,04$ \\
\hline
\end{tabular}

11. tabula. Respondentu spējas segt izmaksas noteiktās jomās (pēc regiona)

\begin{tabular}{lcr} 
Regions & $\begin{array}{r}\text { Labumu skaits, ko } \\
\text { mājsaimnieciba } \\
\text { var ațauties (vid.) }\end{array}$ & $\begin{array}{r}\text { Drošticamības } \\
\text { intervāls }\end{array}$ \\
\hline Rigga & 5,9 & $5,75-6,04$ \\
\hline Vidzeme & 5,0 & $4,68-5,26$ \\
\hline Kurzeme & 5,1 & $4,78-5,33$ \\
\hline Zemgale & 5,5 & $5,18-5,79$ \\
\hline Latgale & 5,4 & $5,14-5,66$ \\
\hline Pierīga & 5,4 & $5,12-5,68$ \\
\hline
\end{tabular}

dažādu labumu var atḷauties respondenti atkarībā no nepilngadīgo bērnu skaita mājsaimniecībā (10. tabula). Dati tomēr rāda, ka sākotnējais pieṇēmums nav apstiprinājies. Pirmkārt, atšķirības pēc nepilngadīgo bērnu skaita nav saturiski nozīmīgas - tās svārstās \pm 1 labuma robežās. Otrkārt, mājsaimniecībām bez nepilngadīgiem bērniem vidējais pieejamo labumu skaits ir nedaudz mazāks nekā pārējām divām grupām (ar vienu un vairākiem
12. tabula. Respondentu materiālās nodrošinātības kategoriju îpatsvars (pēc regiona)

\begin{tabular}{|c|c|c|}
\hline Kategorijas & $\begin{array}{l}\text { T̄patsvars } \\
\text { Rīga } \bar{a}^{*}\end{array}$ & $\begin{array}{r}\text { T̄patsvars } \\
\text { pārējā Latvijāā }\end{array}$ \\
\hline $\begin{array}{l}\text { Pirmā (mājsaimniecība nevar } \\
\text { atḷauties 6-8 lietas no saraksta) }\end{array}$ & 4,3 & 15,7 \\
\hline $\begin{array}{l}\text { Otrā (nevar atlauties } \\
4-5 \text { lietas no saraksta) }\end{array}$ & 18,8 & 22,3 \\
\hline $\begin{array}{l}\text { Trešā (nevar atḷauties } \\
3 \text { lietas no saraksta) }\end{array}$ & 16,8 & 12,5 \\
\hline $\begin{array}{l}\text { Ceturtā (nevar atlauties } \\
\text { 1-2 lietas no saraksta) }\end{array}$ & 33,3 & 22,7 \\
\hline $\begin{array}{l}\text { Piektā (var atḷauties } \\
\text { visu no saraksta) }\end{array}$ & 26,8 & 27 \\
\hline
\end{tabular}

* Īpatsvars Rỉgai un pārējai Latvijai noapalots lïdz desmitdalạm.

bērniem). Treškārt, atškirības starp mājsaimniecībām ar vienu un vairākiem bērniem ir minimālas un statistiski nenozīmīgas.

Latvijas specifika ar pilsētu un novadu izteikti nevienmērīgu attīstības līmeni un dinamiku diktē nepieciešamību salīdzināt dzìves līmeni raksturojošos rādītājus arī reǵionālā griezumā. Reǵionu atšḳirības nešḳiet izteiktākas par izglìīibas līmeṇu atšḳirībām, taču ir vērā ṇemamas atziṇas. Pirmkārt, pretēji vispāratzìtajam pienēemumam, ka Latgale sociālekonomiskās situācijas zinā ir problemātiskākais Latvijas reǵions, vidējais labumu skaits, kuru var aț̣auties Latgali pārstāvošie respondenti, ir 5,4-tas ir vienā līmenī ar Pierīgu un augstāk nekā vidējie rādītāji Vidzemē $(5,0)$ un Kurzemē $(5,1)$. Otra svarịga atzina ir tāda, ka vienịgā statistiski nozīmīgā atškirība, izmantojot iepriekš izklāstìto astoṇu labumu skalu, ir starp Rỉgu un pārējiem pieciem reğioniem, ṇemot vērā drošticamības intervālus (turklāt Rỉgai tie margināli pārklājas ar Zemgali, kura, pēc izveidotās skalas loǵikas, materiālās un sociālās nodrošinātỉbas ziṇā ierindojas otrajā vietā aiz Rỉgas).

Izmantojot šādu vienkāršotu pieeju, salīdzināsim dažādos deprivācijas limmenos esošo mājsaimniecỉbu îpatsvaru Rỉgā un pārējās Latvijas reg̣ionos, lietojot krustojuma tabulas metodi. Kopumā atškirības ir statistiski 
nozimigigas $\left(\chi^{2}=72,77 ; p<0,001\right)$, taču no tabulas redzams, kuru deprivācijas līmeṇu ieguldījums atšḳirīibu tapšanā ir būtiskākais. Viskrasāk tās izpaužas, salīdzinot visnelabvēlīgāk situēto mājsaimniecību ìpatsvaru Rīgā $(4,3 \%)$ un pārējā Latvijā (15,7\%), kur tas sasniedz gandrīz vienu sesto daḷu mājsaimniecību. Otrajā vietā ierindojas atškirīibas 4., salīdzinoši pārtikušajā kategorijā, kas var atḷauties lielāko dạ̣u no astoṇiem labumiem - Rīgā tās īpatsvars ir viena trešã dala, un tas pusotru reizi pārsniedz ipatsvaru pārējā Latvijā, kur tas nedaudz pārsniedz vienu piekto dalu. Tai pašā laikā interesanti, ka vislabāk situētā kategorija ir vienlìdz pārstāvēta Rỉgā un pārējā Latvijā (26,8\% un 27\%).

Nabadzības un materiālās nenodrošinātības izpausmes: kuru vajadzību apmierināšana ir problemātiskāka?

Nabadzību un nenodrošinātību vērts aplūkot arī specifiskāk - pirmkārt, kā tā izpaužas samērā ìsā laika posmā, un, otrkārt, kā izpaužas, risinot konkrētākus jautājumus vai problēmas (piemēram, ārsta izrakstīto zālu iegāde, bērnu mācībām nepieciešamā inventāra pirkšana vai kino kā atpūtas pasākuma apmeklējums). Šim nolūkam SUSTINNo pētijumā tika uzdota sērija specifisku jautājumu par to, vai pēdējo 12 mēnešu laikā no aptaujas veikšanas brīža respondentu mājsaimniecībā (ğimenē) ir bijušas noteikta veida situācijas, kas saistītas ar nespēju segt izdevumus par noteiktām vajadzībām (piemēram, nevarēja samaksāt par mājokḷa īri). Jautājumi aptvēra pienācīgai dzīvei svarīgus pakalpojumus un aktivitātes, kas skar iztiku, mājokla uzturēšanu, veselības aprūpi, kontaktus ar radiem un draugiem, bērnu izglìīibas vajadzības, kā arī atpūtas un kultūras vajadzības. Jautājums paredzēja četrus atbilžu variantus, kas parāda, vai respondents vienmēr varēja segt šos izdevumus vai 1-2 reizes vai 3 un vairāk reizes nevarēja segt šos izdevumus, vai arī viņam nebija nepieciešamības risināt attiecīgo problēmu (piemēram, ja mājsaimniecībā nav bērnu, tad nebija arī vajadzības pirkt mācībām nepieciešamo inventāru). Analīzes vienkāršības labad 2. un 3.variants tika apvienoti, lai kopumā raksturotu tādus gadijjumus, kuros respondenta mājsaimniecība kaut reizi pārskata periodā nespēja segt izdevumus konkrētā situācijā. Respondentu atbilžu sadalījums attēlots 13.tabulā. Beidzamajā ailē attēlota attiecība starp to respondentu ipatsvaru, kuri kaut vienu reizi pēdējo 12 mēnešu laikā nespēja segt attiecīgos izdevumus, pret kopējo respondentu īpatsvaru, kuriem šāda vajadzỉba bija (aprēķinā neietverot respondentus, kuriem šādas vajadzibas nebija). Piemēram, pirmajā apakšjautājumā $18,5 \%$ respondentu, kuriem bija nepieciešamiba samaksāt par mājokḷa īri, vismaz vienu reizi pēdējo 12 mēnešu laikā nevarēja to atlauties, jo 13,9: $(13,9+61,1)=0,185$. Šajā aprēkinā netika nemti vērā tie respondenti, kuri norādīja, ka viniem nav bijusi šāda nepieciešamība $(25 \%)$.

13. tabula. Respondentu iespējas segt izmaksas dažādu vajadzību apmierināšanai

Situācija, kas prasija noteiktu izdevumu segšanu

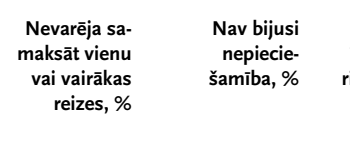

\begin{tabular}{|c|c|c|c|c|}
\hline Jāsamaksā par mājokḷa īri & 61,1 & 13,9 & 25 & 18,5 \\
\hline $\begin{array}{l}\text { Jāsamaksā par komunālajiem pakalpojumiem } \\
\text { (siltumu, ūdeni, elektrību) }\end{array}$ & 78,7 & 18,8 & 2,5 & 19,3 \\
\hline $\begin{array}{l}\text { Jāiegādājas mājsaimniecībā nepieciešamās } \\
\text { mēbeles (galds, gulta, krēsls u.tml.) }\end{array}$ & 49,4 & 23,9 & 26,7 & 32,6 \\
\hline $\begin{array}{l}\text { Jānomaksā parādi, lai tiktu atjaunota komunālo } \\
\text { pakalpojumu sniegšana (elektrỉbas, siltā ūdens } \\
\text { padeve) }\end{array}$ & 93,7 & 3,2 & 3,1 & 3,3 \\
\hline Jāiegādājas ārsta izrakstītās zāles & 70 & 16,5 & 13,5 & 19,1 \\
\hline $\begin{array}{l}\text { Jāsamaksā par ārsta noteiktajiem } \\
\text { izmeklējumiem (analīzēm, pārbaudēm) }\end{array}$ & 71,4 & 14,4 & 14,2 & 16,8 \\
\hline $\begin{array}{l}\text { Jāizmanto dārgi pakalpojumi-jāapmeklē } \\
\text { zobārsts vai zobu higiēnists }\end{array}$ & 57,8 & 27,4 & 14,8 & 32,2 \\
\hline $\begin{array}{l}\text { Jānopērk ikdienā nepieciešamie pārtikas } \\
\text { produkti }\end{array}$ & 87,8 & 10,5 & 1,7 & 10,7 \\
\hline $\begin{array}{l}\text { Jānopērk mājsaimniecībā nepieciešamās lietas } \\
\text { (mazgāšanas līdzekḷi, sīkais inventārs) }\end{array}$ & 85,9 & 12,3 & 1,8 & 12,5 \\
\hline Jāapmeklē frizieris & 77,2 & 15,9 & 6,9 & 17,1 \\
\hline $\begin{array}{l}\text { Jānopērk bērnam pedagogu prasītais inventārs } \\
\text { vai mācību līdzekḷi (bērnudārzā un/vai skolā) }\end{array}$ & 39,7 & 2,6 & 57,7 & 6,1 \\
\hline $\begin{array}{l}\text { Jāsamaksā par izglitīibas iestāžu } \\
\text { organizētajām ekskursijām, koncertu un } \\
\text { izrāžu apmeklējumiem }\end{array}$ & 40,0 & 4,1 & 55,9 & 9,3 \\
\hline
\end{tabular}




\begin{tabular}{|c|c|c|c|c|}
\hline Situācija, kas prasija noteiktu izdevumu segšanu & $\begin{array}{l}\text { Varēja samak- } \\
\text { săt vienmēr, \% }\end{array}$ & $\begin{array}{r}\text { Nevarejaj sa- } \\
\text { maksăt vienu } \\
\text { vai vairăkas } \\
\text { reizes, \% }\end{array}$ & $\begin{array}{c}\text { Nav bijusi } \\
\text { nepiecie- } \\
\text { samiba, \% }\end{array}$ & $\begin{array}{r}\text { Respondentu } \\
\text { ippatsvars, ku- } \\
\text { riem izmaksas } \\
\text { bija jāsedz, } \\
\text { bet ddazreiz to } \\
\text { nevarēja, \% }\end{array}$ \\
\hline $\begin{array}{l}\text { Jāapciemo radinieki citā pašvaldībā Latvijā un } \\
\text { jāsedz transporta pakalpojumi (biḷetes, degviela) }\end{array}$ & 61,3 & 24,3 & 14,4 & 28,4 \\
\hline $\begin{array}{l}\text { Jāapciemo tuvi draugi citā pašvaldībā Latvijā un } \\
\text { jāsedz transporta pakalpojumi (biletetes, degviela) }\end{array}$ & 60,7 & 24,8 & 14,5 & 29,0 \\
\hline $\begin{array}{l}\text { Jāsvin dzimšanas diena vai vārda diena sev vai } \\
\text { kādam ǵimenes loceklim }\end{array}$ & 74,5 & 20,0 & 5,5 & 2I,2 \\
\hline Jāapmeklē kino, teātra izrāde vai koncerts & 57,1 & 32,4 & 10,5 & 36,2 \\
\hline
\end{tabular}

izdevumu prioritātes, tam būtu nepieciešama padzilināta izpēte. Tomēr aptaujas rezultātu analīze liek domāt, ka cilvēki ḷoti rūpīgi apsver izdevumu prioritātes-komunālie maksājumi ir jāsedz, jo var atslēgt pakalpojumu, bet vecās mēbeles var ari nenomainit, jo no tā nekas slikts nenotiek; bērnu izglìtībā nepieciešamie izdevumi ir jāsedz, lai bērns ieklautos izglìitibas sistēmā un klases kolektivā, bet personiskās vajadzỉbas, kā tālāk dzivojošu radu un draugu apciemošana, var arī atlikt; pie friziera ir jāiet, jo uz darbu jādodas sakoptā izskatā, kamēr pie zobārsta vai zobu higiēnista var arī neaiziet, ja vien nav patiešām liela nepieciešamība utt. Kopumā jāsecina, ka nabadzībai un materiālai nenodrošinātībai piemìt multidimensionāla ietekme, kas pasliktina nevis kādu vienu vai divas jomas, bet gan cilvēku dzīves kvalitāti reizē vairākos veidos un virzienos.

Secinājumi: nabadzību veicinošo faktoru daudzdimensionālā ietekme
Šajā rakstā pamatota nepieciešamība apzināt alternatīvas pieejas nabadzības, sociālās atstumtības un materiālās nenodrošinātỉbas mērī̌šanai. Tradicionālās pieejas, kas raugās uz šo problemātiku caur ienākumu prizmu, neḷauj ṇemt vērā iedzīvotāju (mājsaimniecību) faktisko izdevumu struktūru un tās atbilstỉbu ienākumiem; turklāt cilvēki ne vienmēr precīzi norāda savus ienākumus apsekojumos un aptaujās, kā arī neatbildētỉbas rādītāji ir visai augsti, sasniedzot $25-30 \%$. Kā līdzvērtīgu un nepieciešamu papildinājumu pētnieki iesaka lietot indikatorus, kas raksturo izdevumu struktūru, piemēram, lūdzot respondentiem norādìt, vai vini var atlauties segt izmaksas noteiktās jomās (piemēram, pirkt un/vai uzturēt noteiktas lietas vai samaksāt par pakalpojumiem). Arī šai pieejai piemìt zināmi riski, jo neviens izmaksu saraksts nebūs pilnīgs un ideāls. Lìdz ar to izdevumu indikatori papildināmi ar jautājumiem, kas raksturo finansiālo vai materiālo grūtību iestāšanos specifiskākās jomās īstermiṇa vai vidējā termiṇa periodos - piemēram, pēdējo 12 mēnešu laikā. Tikai kombinējot vairākas pieejas materiālās (ne)nodrošinātības un sociālās ieklaušanās identificēšanai, ir iespējams adekvāti izvērtēt nabadzības un sociālās atstumtības izplatību un riskus.

SUSTINNO datu deskriptīvā analīze liecina, ka 47,1\% jeb gandrīz puse mājsaimniecību nevar atlauties trīs vai vairāk no astonām pozīcijām, kuras pētnieki izvēlējās kā pienācīgu mūsdienu dzives līmeni raksturojošas un kuras dạ̣ēji pārklājas ar materiālās nodrošinātības standarta rādītājiem. Savukārt to mājsaimniecību ipatsvars, kas nevar atlauties četras vai vairāk pozīciju no šĩ saraksta, ir 33,9\%. Balstoties uz šiem rādītājiem, aptuveni viena trešā dạıa Latvijas mājsaimniecību atzīstamas par nabadzīgām, un vēl 13,2\% atrodas riska zonā. No vienas puses, iekḷaujot spēju segt izdevumus par jaunu apgoērbu, nevis spēju veikt remontu, kad tas ir nepieciešams, situācija 
būtu škiietami labāka - jo gan SUSTINNO aptaujas, gan Centrāāās statistikas pārvaldes apsekojumu dati rāda, ka aptuveni 70\% iedzivotāju nav grūtību iegādāties jaunu apg̛̣ērbu. No otras puses, apgêeerbs ir pamata nepieciešamỉba, tāpat kā èdiens un mājoklis, kamēr iespējas savu mājokli labiekārtot un uzturēt estētiskā kārtỉbā jau liecina par dzives kvalitāti. Ja Latvija vēlas nostiprināt stabilu vidusšķiru, tad izvēlētie rādītāji labāk parāda mūsu attālumu no šì mērḳa nekā klasiskie materiālās nenodrošinātības rādìtāji.

Ir jāapzinās, ka nespējai segt noteiktas izmaksas ir komplekss un lavinnveidīgss efekts. Piemēram, nespējot samaksāt par ārstēšanu, medicīniskiem izmeklējumiem vai zālēm, cilvēkam pasliktinās veselība, kā rezultātā viņš var dalēji vai pilnīgi zaudēt darbspēju un piemērotību darba veikšanai, bet ilgtermin̄ā tas var nozīmēt darba zaudēšanu un vēl krasāku ienākumu samazināšanos un nespēju segt vairākas citas izmaksas. Citos iespējamos scenārijos riskus veselïbai rada arī nespēja vai ierobežotā spēja samaksāt par komunālajiem pakalpojumiem (siltumu, ūdeni, elektrību) vai iegādāties pārtiku, savukārt nespēja uzturēt sociālos kontaktus ar līdzcilvēkiem, kā arī apmeklēt sabiedriskas kultūras aktivitātes var sekmēt psiholoğisku problēmu rašanos, sociālo izolāciju un marginalizāciju.

Deprivācijas prognozēšanai jāaptver arī tās saistība ar svarīgākajiem sociāldemogrāfiskajiem faktoriem. Datu analīze parādijja, ka būtisku atšḳirību starp vïriešu un sieviešu materiālo nenodrošinātìbu nav, kā arī bērnu skaits g̛̣imenē nav nozīmīgs faktors. Šie secinājumi atšḳiras no datiem par nabadzības riskam pakḷauto iedzivotāju īpatsvaru dažādās sociāldemogrāfiskajās grupās un mājsaimniecībās, tāpēc saistība starp ienākumiem un mājsaimniecību vajadzībām un izdevumu struktūru prasītu papildu izpēti. Savukārt tādi faktori kā nodarbinātỉba un izglìtỉba rada nozīmìgas materiālā nodrošinājuma atšḳirības (šāda sakarỉba parādās arì citos pētijjumos, kā iedzivotāju ienākumu un dzīves apstāklu apsekojumos (Centrālā statistikas pārvalde, 2016; 2017b)). Piemēram, pie nabadzīgākās kategorijas pieder ap $7 \%$ strādājošo un viena piektā daḷa nestrādājošo, savukārt to respondentu vidū, kuru mājsaimniecība var ațauties tērinuus visās astonāa jomās, atrodami $32,2 \%$ visu strādājošo un mazāk nekā $20 \%$ visu nestrādājošo respondentu. Indivīdi ar salīdzinoši augstāku izglìtības līmeni ir labāk nodrošināti (Spīrmena $\rho=0,25 ; \boldsymbol{p}<0,01)$ - vidējie nodrošinātības rādìtāji personām ar augstāko izglitīibu ir visai labvēlīgi (var segt izmaksas 6 no 8 definētajām jomām), kamēr indivīdi ar pamatizglìīibu un arodizglitīibu ir visvairāk pakḷauti nabadzības riskam. Reğionālā griezumā pastāv acìmredzama plaisa starp Latvijas reğioniem, seviški starp galvaspilsētu Rīgu un pārējo Latviju. Piemēram, nabadzīgākajai kategorijai Rīgā ir piederīgi tikai 4,3\% mājsaimniecību, bet pārējos Latvijas reğionos - vairāk nekā $15 \%$. Nabadzību veicinošie faktori neiedarbojas izolēti, atrauti cits no cita, bet mēdz cits citu pastiprinātšỉ iemesla dēḷ, piemēram, cilvēki ar salīdzinoši zemu izglìtības lỉmeni, kas dzīvo samērā nabadzīgā reǵ̛ionā, saskaras ar lielāku nabadzības risku nekā tādi paši cilvēki Rīgā vai arī citu reǵionu iedzīvotāiji ar augstāko izglīitibu.

Kaut gan nabadzības rādītāji pēc sociālajiem transfertiem ir ievērojami zemāki nekā pirms tiem (piemēram, 2014. gadā pirms sociālajiem transfertiem nabadzības riska indekss bija 40,9\%, kā rāda Centrālās statistikas pārvaldes dati (2016)), SUSTINNO pētỉjumā konstatētie materiālās nenodrošinātības un dažādu vajadzību apmierināšanas rādītāji liecina, ka iedzīvotāji ar zemākajiem ienākumiem var nodrošināt tikai pamata vajadzības minimālā līmenī un materiālā deprivācija ir nevis dziḷa, bet katastrofāla. Tas nozīmē, ka patlaban san̨emtais sociālais atbalsts nav pietiekošs, lai nodrošinātu kaut vai minimālu pienācīgas dzīves līmeni. Minimālie sociālās palīdzības sliekšṇi ir zemi un ilgstoši nav tikuši pārskatīti, kā arī to apjoms nav zinātniski pamatots (Labklājibas ministrija, 2014a). Arī Pasaules Bankas eksperti ir norādījuši, ka Latvijā minimālā ienākuma atbalsts ir neadekvāti zems un turklāt ar pārāk zemu pārklājumu (The World Bank, 2013). Eiropas Parlaments ir aicinājis dalībvalstis ieviest minimālā ienākuma slieksni pat $60 \%$ no ienākumu mediānas valstī, lai panāktu, lai minimālais ienākums būtu pietiekama aizsardzības sistēma marginalizētām un mazaizsargātām personām (Eiropas Parlaments, 2010).

2017. gada vasarā pieṇemtā nodokḷu reforma varētu būt leǵendāra tieši ar to, ka pirmo reizi Latvijas neatkarības vēsturē kopš 1991. gada ir pieṇemti nopietni nodokḷu atvieglojumi cilvēkiem ar zemiem ienākumiem un progresīva iedzivotāju ienākumu nodokḷa likme. Tomēr jautājums par zinātniski pamatota minimālā ienākumu līmena noteikšanu un ar to saistìtās iespējas sanemt adekvātu sociālo palīdzỉbu joprojām paliek plānu un diskusiju līmenī. Garantētā minimālā ienākuma (GMI) apjoms 2005. gadā tika noteikts 29,88 eiro, 2010. gadā tas tika palielināts līdz 56,91 eiro, bet jau 2013. gadā samazināts lìdz 49,80 eiro mēnesī. Turklāt GMI pabalsta vidējais apmērs, ko saṇem persona mēnesī, 2005. gadā bija tikai 15,74 eiro un 2016. gadā tikai 38 eiro mēnesī (Celminina, 2017). Slieksnis trūcīgas personas ienākumu līmenim kopš 2005. gada gan ir dubultojies (2005. gadā tas bija 56 eiro, kopš 2009. gada tas ir noteikts 128,o6 eiro uz cilvēku mājsaimniecībā), tomēr joprojām tas nav saistīts ar aprēḳiniem par iztikas minimuma patērina groza vai pienācīgas dzìves līmeṇa nodrošinājumu, kā arī nav saistìts ar ienākumu mediānu valstī, kaut arī trūcīgas personas ienākumu līmenim atbilst 83000 personu jeb $5 \%$ iedzīvotāju. Labklājības ministrijas Sociālās iekḷaušanas politikas koordinācijas komitejas materiālos var atrast priekšlikumu noteikt minimālā ienākuma līmeni un trūcīgas personas ienākuma līmeni kā 40\% no rīcībā esošā ienākuma mediānas, kas atbilstoši 2016. gada vērtībai vienam ekvivalentajam patēētājam mājsaimniecībā bija 188,oo eiro. GMI limmeni plānots noteikt kā $1 / 2$ no trūcīgas personas ienākumu līmena jeb $20 \%$ no ienākumu mediānas, kas attiecīgi būtu 
94,00 eiro (Celmina, 2017). Kaut arī tas neatbilst Eiropas Savienības rekomendācijām par minimālo ienākumu līmeni sekmīgai nabadzības apkarošanai un sociālās kohēzijas veicināšanai, tas tomēr būtu būtisks progress. Pat šie pieticīgie soḷi atbilstoši Labklājibas ministrijas aprēḳiniem prasìtu virs 30 miljoniem papildu finansējuma ik gadu. Acīmredzot arī tādēl šie priekšlikumi tālāk valdībā netiek atbalstīit un koncepcija par minimālā ienākumu līmeṇa noteikšanu netiek istenota tajā laika grafikā, kas tika sākotnēji paredzēts un 2014. gadā Ministru kabinetā apstiprināts. Jāuzsver, ka sociālās aizsardzības izdevumi Latvijā ir vieni no zemākajiem Eiropas Savienībā-2015. gadā vidēji Eiropas Savienības valstis sociālajai aizsardzībai atvēlēja 19,2\%, kamēr Latvija tikai 11,5\% no IKP (Platais, 2017).

Kaut arì kopumā labklājības rādītāji valstī uzlabojas un gandrīz puse valsts iedzīvotāju var aț̣auties segt izdevumus, kas raksturo pienācīgas dzīves līmeni, apmēram trešā dala saskaras ar nopietniem ierobežojumiem, bet piektā dala - ar smagiem ierobežojumiem. Šì situācija prasa kompleksus risinājumus. Valsts sociālās un ekonomiskās politikas plānošanā lielāka nozìme būtu pievēršama nabadzības, materiālās nodrošinātỉbas un sociālās ieklaušanās novērtēšanai, nemot vērā ne tikai mājsaimniecību ienākumus un nodarbinātības intensitāti, bet arī izdevumu struktūru un spēju segt izmaksas par pakalpojumiem un aktivitātēm dažādās jomās (mājokḷa, izglītỉbas, veselības, kultūras u. c.). Šāda pieeja lautu nākotnē veidot un pielietot elastīgākus risinājumus, piemēram, pabalstu un atvieglojumu formā (tai skaitā nodokḷu atvieglojumu), ḷaujot aizvietot ienākumu līmeni kā tradicionāli formālu kritēriju ar rādītājiem, kas pilnīgāk un arī objektīvāk atspoguḷo mājsaimniecību un indivìdu sociālekonomiskās vajadzỉbas un iespējas tās apmierināt. N̦emot vērā nodarbinātības, izglììibas un arī reǵionālās dimensijas ietekmi uz nodrošinātỉbu, valstij būtu jāpilnveido un jāattīsta izglìitibas iegūšanas iespējas, kā arī iespējas pārkvalificēties tiem, kas ilgstoši nevar atrast iegūtajai izglìtibai, prasmēm un dotībām atbilstošu darbu. Nodrošinot šādas iespējas, īpaša uzmanība būtu pievēršama Latvijas reǵioniem, jo tikai tā var sekmēt Latvijas sabiedrỉbas un tautsaimniecỉbas lídzsvarotu un ilgtspējigu attīstỉbu. Visbeidzot, n̦emot vērā Latvijas demogrāfisko situāciju, būtu jāveido un jāisteno tāda politika (tai skaitā plaši lietojot nemonetāros līdzekḷus, piemēram, attīstot atbilstošu infrastruktūru), kas cilvēkiem lautu palikt Latvijā un veicinātu izvēlēties par savu dzivesvietu ne tikai Rìgu un Pierīgu, lautu dibināt ğimeni un aț̣auties bērnus, neuztraucoties par iespējām nodrošināt sev un bērniem visu pienācīgai dzīvei nepieciešamo.

\section{Izmantotie avoti}

ANO Vispārēèa cilvēktiesību deklarācija (1948). Pieṇemta un pasludināta ar Generālās Asamblejas 1948. gada 10. decembra 217. A (III) rezolūciju. Izgūts no http://www.tiesibsargs.lv/tiesibu-akti/ano-dokumenti/ano-visparejacilvektiesibu-deklaracija/

Buchanan, A. (2005). Equality and Human Rigths. Politics, Philosophy and Economics, 4(1), 69-9o. https://doi.org/10.1177/1470594X05049436

Celmiṇa, E. (2017). Plāns minimālo ienākumu sistēmas pilnveidošanai. Sociālās iekḷaušanas politikas koordinācijas komitejas materiāli 2017.gada 21.aprịla sēdē. Rīga: Labklājības ministrija. Izgūts no http://www.lps.lv/uploads/ docs_module/4_Pl $\% \mathrm{C}_{4} \% 81 \mathrm{~ns} \operatorname{minim} \% \mathrm{C} 4 \% 81$ lo ien $\% \mathrm{C}_{4} \% 81$ kumu atbalsta sist\%C4\%93mas pilnveido\%C5\%A1anai.pdf

Centrālā statistikas pārvalde (2015). Ekonomiskā spriedze. Terminu skaidrojums. Izgūts no http://www.csb.gov.lv/statistikas-temas/termini/ekonomiskaspriedze-36o7o.html

Centrālā statistikas pārvalde (2017a). Definìcijas. Monetārās nabadzïbas, ienākumu nevienlïdzïbas indikatori (EU-SILC apsekojums). Izgūts no http://www. csb.gov.lv/statistikas-temas/metodologija/nabadzibas-ienakumunevienlidziba-36833.html

Council of the European Union (2004). Joint report by the Commission and the Council on social inclusion, 7101/04 C.F.R. Brussels, 5 March 2004. Retrieved from http://ec.europa.eu/employment_social/soc-prot/soc-incl/final_joint inclusion_report_2003_en.pdf

Eiropas Parlaments (2010). Minimālà ienākuma nozìme nabadzìbas apkarošanā un integreējošas sabiedrības attīstības veicināšanā Eiropā. Rezolūcija apstiprināta ar Eiropas Parlamenta 2010. gada 20. oktobra lēmumu (2010/2039(INI)). Izgūts no http://eur-lex.europa.eu/legal-content/LV/ALL/?uri=CELEX:52010IPo375

Gordon, D., Levitas, R., Pantazis, C., Patzios, D., Payne, S., Townsend, P., ... Williams, J. (2000). Poverty and social exclusion in Great Britain. York: Josep Rowntree Foundation.

Hazans, M. (2012). Latvijas darba tirgus krizes laikā. No A. Oslunds, V. Dombrovskis, Kà Latvija pärvarēja finanšu krīzi (254.-264.lpp.). Rïga: Ekonomistu apvieniba 2010.

Helmane, I. (2017). Vai vidèjāa alga raksturo labklājību? Latvijas Vēstneša portāls, 07.09.2017. Izgūts no http://m.lvportals.lv/visi/viedokli/289543-vai-videjaalga-raksturo-labklajibu/

Labklājības ministrija (2014a). Koncepcija par minimālā ienākuma līmena noteikšanu. Ministru kabineta 2014. gada 30. oktobra rikojums Nr.619. Izgūts no http://www.lm.gov.lv/upload/sociala_ieklausana/koncepcija_fin.pdf

Labklajỉbas ministrija (2014b). Nacionālais sociālais zinojums. Izgūts no WwW. lm.gov.lv/upload/sociala_aizsardziba/.../nsr_2014_latvia fin2.pdf 
Labklājības ministrijas Sociālās iekḷaušanas un sociālā darba politikas departaments (2016). Valsts statistikas pārskatu kopsavilkums. Pārskati par sociālajiem pakalpojumiem un sociālo palīdzìbu novada/republikas pilsêtas pašvaldībā 2015. gadā. Izgūts no http://www.lm.gov.lv/text/3400

Lāce, T. (2012). Sociālā atstumtība Latvijā. Rīga: Zinātne.

Lehtinen, A. R., Varjonen, J., Raijas, A., \& Aalto, K. (2011) Reference budgetsfor the decent minimum standard of living. National Consumer Research Centre. Working papers 132. Retrieved from https://www.researchgate.net/ publication/259772177_What_Is_the_Cost_of_Living_Reference_Budgets for_a_Decent_Minimum_Standard_of_Living_in_Finland

Oslunds, A., \& Dombrovskis, V. (2012) Kã Latvija pārvarēja finanšu krīzi. Rīga: Ekonomistu apvieniba 2010.

Pārresoru koordinācijas centrs (2012). Latvijas Nacionālais attīstības plān 2014.-2020. gadam. Apstiprināts ar 2012. gada 20. decembra Latvijas Republikas Saeimas lēmumu. Izgūts no http://www.varam.gov.lv/lat/pol/ ppd/ilgtsp_att $/ ?$ doc $=13858$

Platais, J. (2017). Ilgtspēja un publiskais sektors. Ekspertu diskusija par publiskā sektora ilgtspēju. 2017. gada 6. jūnijs. Rỉga: Fiskālās disciplinnas padome. Izgūts no http://fdp.gov.lv/diskusija-par-publiska-sektora-ilgtspeju

RAIM (2017). Datu izğuves un analīzes rîki. Reğionālās attīstỉbas indikatoru modulis. Rỉga: Valsts reğionālās attisstibas ağentūra. Izgūts no http://raim gov.lv

Saeima (2010). Latvijas ilgstspējigas attīstības stratếgija līdz 2030. gadam. Apstiprināts ar 2010.gada 10.jūnija Latvijas Republikas Saeimas lēmumu. Izgūts no http://www.latvija203o.lv/upload/latvija203o_saeima.pdfLR Saeima Sen, A. (1999). Development as Freedom. New York: Anchor Books.

Spector, P.E. (1992). Summated rating scale construction: an introduction. Newbury Park: Sage Publications.

Suter, C., \& Iglesias, K. (2005). Relative Deprivation and Well-being: Switzerland in a Comparative Perspective. In H. Kriesi, P. Farago, M. Kohli \& M.Zarin-Nejadan (Eds.), Contemporary Switzerland (pp.9-37). London: Palgrave Macmillan. https://doi.org/10.1057/9780230523586_2

United Nations (1995). Report of the World Summit for Social Development. A/ CONF.166/9. Copenhagen, Denmark, 6 to 12 March 1995. Retrieved from http://www.un.org/documents/ga/conf166/aconf166-9.htm

United Nations (2015). Transforming our world: the 2030 Agenda for Sustainable Development. A/RES/70/1. Resolution adopted by the General Assembly on 25 September 2015. Retrieved from http://www.un.org/ sustainabledevelopment/sustainable-development-goals/

United Nations Conference on Environment \& Development (1992). AGENDA 21. Rio de Janerio, Brazil, 3 to 14 June 1992. Retrieved from https:// sustainabledevelopment.un.org/content/documents/Agenda21.pdf
Wilkinson, R., \& Pickett, K. (2010). The Spirit Level: Why Greater Equality Makes Societies Stronger. New York: Bloomsbury Publishing.

Walker, R. (2014). The Shame of Poverty. Oxford: Oxford University Press.

The World Bank (2013). Latvia: Who is Unemployed, Inactive or Needy? An Assessmen

of Post-Crisis Policy Options. Retrieved from http://www.lm.gov.lv/text/2562

\section{Datu avoti}

Centrālā statistikas pārvalde (2016). Ienākumi un dzives apstāklli Latvijā 2015. gaadā. Statistisko datu krājums. Rīga. Izgūts no http://www.csb.gov.lv/dati/epublikacijas/ienakumi-un-dzives-apstakli-latvija-2015-gada-44193.html

Centrālā statistikas pārvalde (2017b). Ienākumi un dzìves apstākḷi Latvijā 2016. gadā. Statistisko datu krājums. Rīga. Izgūts no http://www.csb.gov.lv/dati/epublikacijas/ienakumi-un-dzives-apstakli-latvija-2016-gada-45988.htm

Centrālā statistikas pārvalde (2017c). 2017. gada 1. ceturksnī bezdarba līmenis Latvija bija 9,4\%. Izgūts no http://www.csb.gov.lv/notikumi/2017-gada-1-ceturksnibezdarba-limenis-latvija-bija-94-46617.html

Centrālā statistikas pārvalde (2017d). Darba samaksa - mēneša vidējā bruto darba samaksa. 1. ceturksnis. Datubāze. Izgūts no http://data.csb.gov.lv/ pxweb/lv/Sociala/Sociala_ikgad_dsamaksa/DSoo40_euro.px/table/ tableViewLayout2/?rxid=cdcb978c-22bo-416a-aacc-aa65odzezceo

Centrālā statistikas pārvalde (2017e). DSGo7. Strādājošso mēneša vidējā darba samaksa republikas pilsētās un novados (bruto, EUR). Darba samaksa.

Datubāze. Izgūts no http://data.csb.gov.lv/pxweb/lv/Sociala/Sociala_ikgad_ dsamaksa/DSoo7o_euro.px/table/tableViewLayout2/?rxid=cdcb978c-22bo416a-aacc-aa65odzezceo

Centrālā statistikas pārvalde (2017f). SDGo5. Strādājošo mēneša vidējā darba samaksa Latvijas reğionos (bruto, EUR). Darba samaksa. Datubāze. Izgūts no http://data.csb.gov.lv/pxweb/lv/Sociala/Sociala_ikgad_dsamaksa/ DSoo5o_euro.px/table/tableViewLayout2/?rxid=cdcb978c-22bo-416a-aaccaa65odzezceo

Centrālā statistikas pārvalde (2017g). NIG15. Nabadzïbas riska indekss Latvijas reğionos pēc vecuma un dzimuma (\%). Monetārās nabadzības un ienākumu nevienlīdzības indikatori. Datubāze. Izgūts no http://data.csb.gov.lv/pxweb/ lv/Sociala/Sociala_ikgad_monetara_nab/NIo15o,px/?rxid=cdcb978c-22bo416a-aacc-aa65odzezceo

Eurostat (2016). People at risk of poverty or social exclusion. Retrieved from http:/ ec.europa.eu/eurostat/statistics-explained/index.php/People_at_risk_of poverty_or_social_exclusion 


\section{Nabadzības strupceḷš: grūtību akumulācija un risinājumu meklējumi sieviešu pieredzes stāstos}

Latvijas attīstības stratēǵiskie mērki ietver vīziju par Latviju kā plaukstošu valsti, kurā aktīvi un atbildīgi pilsoṇi var îstenot savus mērķus un justies droši (Saeima, 2010). Ekonomika lēnām atkopjas pēc krīzes, un pēdējos divus gadus vērojams algu kāpums daudzos tautsaimniecības sektoros. Banku ekonomisti prognozē arì turpmāku mēnešalgu kāpumu (lsm.lv ziṇu redakcija, 2017). Tomēr ekonomiskā izaugsme neskar visas iedzivotāju grupas vienādā mērā un Latvijā joprojām vērojams augsts nabadzības riskam paklauto iedzīvotāju ipatsvars - 2015.gadā Latvijā nabadzības riskam bija pakḷauti 21,8\% iedzìvotāju (jeb 424 tūkstoši). Bet mājsaimniecībās, kurās bērnus audzina tikai viens no vecākiem, nabadzības riskam 2015. gadā bija paklauti pat 34,4\% iedzivotāju (Centrālā statistikas pārvalde, 2017). Jāatzīmē, ka viena vecāka ğimenēs un daudzbērnu g̛̣imenēs nabadzības un sociālās atstumtības rādìtāji ilgsstoši ir ievērojami augstāki nekā vidējie rāditāji Latvijā. Ko nozīmē dzīvot ar ierobežotiem lìdzekliem mūsdienu sabiedrībā, kas vērsta uz izaugsmi un patērinu? Kā trīs un vairāk bērnu vecāki un vecāki, kuri bērnus audzina vieni, sabalansē visas vajadzības? Šajā grāmatas nodạ̣ā tiks padziḷināti pievērsta uzmanība sievietēm, kurām ir zema izglitība un kuras audzina bērnus vienas vai kopāa ar problemātiskiem partneriem,- -viṇas var uzlūkot kā sevišḳi ievainojamu sociālu grupu. Mērḳis ir saprast ilgstošu grūtību situācijas veidošanos šo sieviešu dzīvē, analizēt ikdienas ierobežojumus, to pārvarēšanas stratēĝijas un iespējas, aplūkojot arī sieviešu pieredzi par sanemtās sociàlās palīdzības un pakalpojumu atbilstību vajadzībām.

Pievērsties tādu jaunu sieviešu pieredzes izpētei, kuras ir nonākuša ilğstošās grūtībās un kurām ir bērni, rosina ne tikai problēmas sociālā aktualitāte, bet arī sabiedrībā pastāvošie aizspriedumi. Valstīs, kurās sociālajā jomā tiek isstenota neoliberālā politika, kā Lielbritānijā, pastāv uzskats, ka nabadzigie ir slinki, alkohola vai narkotiku atkarïgi un savtīgi izmanto sociālo pabalstu sistēmu (Fahmi \& Pemberton, 2012). Kaut arī Latvijā vēl nesen vairums cilvēku uzskatijja, ka nabadzība pastāv tādēl, ka sabiedrība nav taisnigi izveidota, tomēr pēdējos gados parādās tendence pieaugtt to cilvēku îpatsvaram, kuri uzlūko nabadzību kā sekas cilvēku slinkumam un gribasspēka trūkumam,-no 20\% 2010. gadā līdz jau 27\% 2013. gadā. Sevišşi šādi uzskati dominēja sabiedrības augšējā slānī-jaunu, izglìtotu un turīgu vīriešu vidū (Rasnača \& Niklass, 2013). Latvijā vairākus gadus pat Labklājības ministrijas ierēdṇi pauda uzskatu, ka daudziem nabadzỉbā dzìvojošiem cilvēkiem ir izveidojusies atkarība no pabalstiem un viṇi negrib strādāt (Rizga, 2012). Šādā sabiedriskās domas kontekstā, kad lēmumus pieṇemošā sabiedrības dala ir tendēta vainot grūtībās nonākušos, ir grūti pieņemt efektīvus lēmumus nabadzības mazināšanai un pārvarēt plaisu starp politikā deklarētiem mērkiem un reālu rīcību, lai mazinātu nabadzību un sociālo atstumtību. Kaut arī neformālās sarunās un intervijās ar pašvaldību sociālajiem darbiniekiem 
apstiprinās, ka ikkatrā pašvaldībā ir atseviški cilvēki un pat ğimenes, kuras patiešām dod priekšroku bezdarbỉbai, to nevar attiecināt uz vairumu grūtībās nonākušo cilvēku. 2013. gadā Pasaules Bankas eksperti veica rūpīgu kvantitatīvu sociālās palīdzības analīzi un atklāja, ka vairums palīdzības sanēmēju to saṇem vienu reizi, isu laika posmu, palïdzïba nav pieejama visiem, kuriem tā nepieciešama, ir nepietiekošā apjomā. Tātad nav iespējams runāt par atkarību no pabalstiem un sociālās palīdzības kā par dominējošu tendenci (The World Bank, 2013). Padzilịnāta grūtībās nonākušu cilvēku pieredzes analīze var palīdzēt labāk saprast situācijas iemeslus un sekas un mazināt iepriekš minētos aizspriedumus.

Nepieciešamība pievērsties grūtību personiskās pieredzes analīzei ir saistīta arī ar apsvērumu, ka sociālās problēmas gan publiskā diskursā, gan sociālās politikas diskusijās un zinātniskos pētijumos pārsvarā tiek aplūkotas, balstoties uz kvantitatīvajiem rādītājiem. Par to var pārliecināties, caurskatot publikācijas zinātnisko žurnālu datubāzēs, sociālās politikas dokumentus un Latvijas Republikas Labklājības ministrijas pasūtītus pētījumus, kā arī virsrakstus Latvijas interneta ziṇu portālos (kā izṇēmums jāmin «Re:Baltica» veidotie pētnieciskās žurnālistikas materiāli). Līdzịgi kā citur (Fahmi \& Pemberton, 2012), Latvijā ir maz pievērsta uzmanība pašiem grūtībās nonākušajiem cilvēkiem, vinu skaidrojumam par sarežgìijumu iemesliem un pieredzei par dzīvi nabadzībā un sociālajā atstumtībā. Tomēr personiskās balss sadzirdēšana var palīdzēt labāk saprast, ka aiz statistikā minētajiem cipariem ir konkrētas dzīves, un var sniegt labāku izpratni par to, ko nozīmē dzīve ar ḷoti ierobežotiem lïdzeklịem uz izaugsmi un patēriṇu vērstā sabiedrībā.

Personiskās pieredzes padziḷināta analīze aktualizē arī svarīgu ētisku jautājumu. Vairāki autori (Fahmy \& Pemberton, 2012; Walker, 2014) norāda, ka jēdzieni «nabadzìba» un «sociālā atstumtība» paši par sevi ir aizvainojoši un ka cilvēki, kurus zinātnieki un dominējošā sabiedrības dalıa šãdi klasificē, nekad nelieto šādus apzīmējumus, kad runā par sevi. To parāda arī 1998. gadā Latvijā tapušais plašais pētijjums par nabadzỉbu (Dudwick et al., 1998). Kā norāda Roberts Volkers (Robert Walker), dzīve nabadzībā ir grūta, bet vēl grūtāk ir to zināt un atzìt. Tiek norādìts, ka dzīve ar ierobežotām iespējām bagātās sabiedrībās ir daudz grūtāka, vispārējās labklājības kontekstā ir daudz grūtāk saglabāt pašcienu savās acīs un sanemt cienpilnu attieksmi no citiem. Apzīmējumus «nabags» un «sociāli atstumts» îslaicīgās vai ilgstošās grūtỉbās nonākušie cilvēki uztver kā pazemojošus un stigmatizējošus (Walker, 2014).

Varam pienemt, ka, lietojot jēdzienus «nabadzība» un «sociālā atstumtība» savos tekstos, zinātnieki šādi turpina uzturēt stigmatizējošu diskursu. Nabadzības objektivizācijas valoda ir raksturīga visiem kvantitatīvajiem pētījumiem un arì daudziem kvalitatīvajiem pētijumiem, kuri pievēršas grūtībās nonākušo cilvēku pieredzes analīzei (Fahmy \& Pemberton, 2012; Walker et al.,
2008; Walker, 2014). Tikai daži autori (piemēram, Martilla et al., 2013) par šīm asajām sociālajām problēmām raksta, respektējot pētījuma dalībnieku pašcieṇu un dodot balsi šai mērḳgrupai. Tādēl centišos nelietot stigmatizējošu valodu diskusijā par to, kā tiek pieredzēta ilgsstoša grūtību akumulācija un dzive ar ierobežotiem lìdzekliem.

Savā ikdienas dzivē mēs pamatā saskaramies ar cilvēkiem, kuriem ir līdzīgi sociālie un ekonomiskie apstākḷi. Kaut arī Latvijā gandrīz trešdala iedzìvotāju ir paklauti nabadzības vai sociālās atstumtības riskam, vairumam sabiedrỉbas šādas pieredzes nav, un veidojas tendence uzskatīt, ka nabadzības cēloṇi meklējami cilvēku slinkumā, nevis sabiedrības un ekonomiskās sistēmas uzbūvē. Tomēr Nobela prēmijas laureāts ekonomikā Jozefs Stiglics (Joseph Stiglitz), kurš padziḷināti analizējis nevienlīdzības un ekonomiskās izaugssmes saistību, parāda tieši sistēmas lomu un uzskata, ka kopš apmēram 1980. gada ekonomiskā izaugssme vairs nenozīmē nevienlïdzības mazināšanos, un tas liek domāt, ka iedzìvotāju ienākumu līmenis ir drīzāk saistīts ar viṇu vietu konkrētajā sistēmā, nevis kādām personiskām īpašỉbām. Viṇš arī pamato, ka mūsdienās nevienlīdzība ir nevis kapitālisma ekonomikas sekas, bet gan pienemto politiku rezultāts, jo kapitālisma ekonomika darbojas līdzīgi visur, tomēr ASV tā rada augstāku ienākumu nevienlīdzību nekā Eiropas valstīs (Stiglitz, 2015). Atsaucoties uz kolēǵu Džona Hilsa (John Hills) un Leina Kenvērtija (Lane Kenworthy) veiktiem pētijumiem, Pols Koplands (Paul Copeland) un Marija Dalī (Mary Daly) uzsver, ka neoliberālās ekonomikās ar salïdzinoši lielu zemu prasmju un slikti atalgotu pakalpojumu sektoru (kả Lielbritānijā) dalība darba tirgū automātiski nemazina nabadzību (Copeland \& Daly, 2012). Arī Latvijā situācija ir līdzīga - nabadzības un materiālās deprivācijas rādītāji ir augstāki par vidējiem Es, kamēr mājsaimniecību ipatsvars ar zemu nodarbinātības intensitāti ir zem ES vidējā (Eurostat, 2016). Arī, savstarpēji salīdzinot Eiropas valstis, Skandināvijā nabadzības un sociālās atstumtības riskam pakḷauto iedzīvotāju īpatsvara rādītāji ir zemāki nekā ES vidējie (pat zem $20 \%$ ), savukārt no bijušās PSRS ietekmes zonas valstīm šie rādītāji ir zemi tikai Slovākijai, Slovēnijai un Čehijai (arī zem 20\%) (Eurostat, 2016). Tas liek domāt par labklājibas valsts modela efektivitāti ienākumu pārdalē un nabadzības mazināšanā.

Atgriežoties pie Latvijas situācijas, dažas grupas ir vairāk ievainojamas (vulnerable) nekā citas, un salīdzinājumā ar 2007. gadā veiktu plašu pētījumu par bezdarba un sociāāās atstumtības iemesliem un ilgumu (Rungule et al., 2007) tādas tās ir jau gadiem - kā seniori (sevišķi tie, kuri dzìvo vieni), bezdarbnieki, cilvēki ar zemu izglìīibu, viena vecāka ğimenes un daudzbērnu ǵimenes. Piemēram, 2014. gadā nabadzības riskam bija pakḷuuti $37 \%$ viena vecāka mājsaimniecību, 34,5\% mājsaimniecību, kurās divi pieaugušie audzina trīs un vairāk bērnus, 55\% bezdarbnieku (Centrālā statistikas pārvalde, 2016). Kā jau minēju, šajā nodalāā padzilināti pievērsīšos tikai vienas specifiskas 
ievainojamo cilvēku grupas pieredzei - jaunām sievietēm ar bērniem, kuras pieder pie viena vecāka ğimenēm vai daudzbērnu ğimenēm, turklāt kombinācijā ar zemu izglìtỉbu, bezdarbu vai nodarbinātību tā saucamajos strupceḷa darbos. Viens no nodalas uzdevumiem ir parādìt, ka nabadzības un sociālās atstumtības augstie rādītāji gan l̦auj identificēt problēmu izplatību, tomēr tikai personīgās balss uzklausiššna palīdz saprast problēmu veidošanos un trūkuma negatīvo seku dziḷumu tā skarto cilvēku dzīvēs, kā arī dziḷāk izprast stigmatizācijas negatīvos efektus un smagos apstākḷos nonākušo cilvēku centienus normalizēt savu dzīvi, vismaz stāstijumā.

Vispirms aplūkošu izpratni par nabadzỉbu un sociālo atstumtību pētījumos, pēc tam iepazisstināšu ar konkrētā pētījuma metodoloǵiju un tālāk pievērsišos sieviešu pieredzes stāstu analizzei.

Nabadzības un sociālās atstumtības objektivizācijas diskurss un personiskās pieredzes balss būtiskums
Izpratne par nabadzìbu un sociālo atstumtību ir laika gaitā mainīga, un pat mūsdienu sociālajās zinātnēs trūkst vienprātîbas par to definēšanu, tāpat kā nav vienprātības par nabadzỉbas cēloṇiem - vai nabadzību pamatā rada strukturāli faktori sabiedrības uzbūvē vai personiskas neveiksmes dzives gaitā (Lāce, 2012; Walker, 2014). Divas galvenās jomas, kas definē šos jēdzienus, ir zinātne un politika. Turklāt tam, kā šos jēdzienus definē politikā, ir ḷoti konkrētas sekas attiecībā uz to, ko valstu valdības dara, lai problēmu risinātu.

Aplūkojot politisko dimensiju, Eiropas attīstības plānošanas dokumentā «Eiropa 2020. Stratēǵija gudrai, ilgtspējiggai un integrējošai izaugsmei» pirmo reizi sociālie mērḳi uzskatīti par tikpat svarīgiem kā ekonomiskie un ierādīta būtiska loma nabadzības mazināšanai (Eiropas Komisija, 2010). Kopš 2010. gada pirmo reizi ES vēsturē attīstības plānošanā nabadzības un sociālās atstumtības mazināšana ir kḷuvusi par nozīmīgu kvantitatīvu sociālu mērki - lïdz 2020. gadam plānots par 20 miljoniem samazināt to cilvēku skaitu, kuriem draud nabadzība. Ne tikai Latvijā, bet arī Eiropas Savienībā ilgstoši ticis uzskatìts, ka «ekonomiskā izaugsme un jaunas darbavietas automātiski radīs lielāku sociālo kohēziju» (Copeland \& Daly, 2012, p. 274), tādēḷ atbalsts sociālas Eiropas idejai ir liels sasniegums.

Sociāāās politikas kontekstā izmērāmi nabadzỉbas un sociālās atstumtības rādītāji ir izšḳiroši svarīgi, jo ḷauj uzskatāmi sekot līdzi situācijai. N̦emot vērā nabadzỉbas jautājuma nozīmīgo lomu politikā, valstis atbalsta regulāru statistikas datu vākšanu, un arī sociālajās zinātnēs vairums pētỉjumu ir balstīti tieši uz kvantitatīvo datu analīzi, pievēršoties nabadzības un sociālās atstumtības riska līmena, dinamikas un sociālā sadalījuma novērtējumam (Fahmy \& Pemberton, 2012). Dažkārt pētījumu loma ir rosināt diskusiju par atbilstošākiem kritērijiem nabadzības mērīšanā un interpretācijā un gandrīz vienmēr - sniegt rekomendācijas politikas veidotājiem. Diemžēe šāds skatijjums nedod dziḷāku izpratni par dzìves trajektorijām, kuru rezultātā cilvēki nonāk grūtībās, ne arī palīdz saprast, ko nozīmē dzìve ar ierobežotiem līdzekliem un ierobežotām iespējām ieklauties sabiedrībā.

Nabadzības jēdziens vēsturiski ticis saistìts ar ienākumu nepietiekamību, kā arī ar finanšu un materiālo resursu trūkumu (Lāce, 2012). Ienākumu nepietiekamība kā nabadzības novērtējuma kritērijs tiek uzskatìts par pārāk viendimensionālu, kas nespēj parādīt daudzveidīgās problēmas, to savstarpējo saikni un ierobežojumus, ar ko saskaras cilvēki, kuriem ir nepietiekoši ienākumi. Diskusijās par nabadzības mērīšanu pētnieki Kristofers Vīlans (Christopher T. Whelan) un Bertrāns Metrs (Bertrand Maître) uzdod interesantu jautājumu saistībā ar pieeju mērìt nabadzību kā ienākumu nepietiekamību - ko īsti parāda tradicionālais relatīvās nabadzības mērijums, lietojot kā nabadzības kritēriju 60\% no ienākumu mediānas valstī? Piemēram, tūkstošgades sākumā nabadzības rādītāii Latvijā bija daudz augstāki nekā Dānijā, kur savukārt bija vieni no zemākajiem nabadzības rādītājiem Eiropā. Ja šos pašus rādītājus pārrēkinātu atbilstoši kā pirktspējas paritāti (purchasing power standarts - PPS), tad parādītos ievērojami lielākas atškirīibas, jo Latvijas rādītājs ir 2300 PPS, kamēr Dānijai-10 200 PPS. Autori apgalvo: kaut arī nabadzības riska slieksnis ir vērtīgs rādītājs un kaut ko liecina par relatīvās nabadzìbas izplatību katrā atseviškā valstī, tas neko daudz neatklāj par ekonomiskajām atšķirīibām starp valstīm un tiem ierobežojumiem, ar ko nabadzỉbai pakḷautie iedzīvotāji saskaras konkrētajā valstī (Whelan \& Maître, 2005b). Starp citu, Eiropas dzìves kvalitātes pētijumā tika secināts, ka Latvijā kvintile (20\%) iedzīvotāju ar augstākajiem ienākumiem saskaras ar lielākām materiālām grūtībām nekā Dānijā kvintile iedzivotāju ar zemākajiem ienākumiem (Eurofound, 2012). Tas nozīmē, ka svarīgs ir gan ienākumu apjoms mājsaimniecībā, gan tas, ko par šo naudu iespējams iegādāties. Bet vissvarīgākais ir vispārējais labklājības līmenis valstī - turīgākās valstīs arī trūcīgāko iedzivotāju ienākumi ir pietiekoši, lai nodrošinātu dzīves pamatvajadzības un noteiktu dzīves kvalitāti, kamēr mazāk labklājigāās valstīs pat turīgākie iedzìvotāji var sastapties ar grūtībām nodrošināt pamatvajadzības un noteiktu dzives kvalitāti.

Tālāk pievērsī̌̌os nabadzības un sociālās atstumtības jēdziena aplūkojumam un to daudzdimensionālā rakstura izpētei, kas ir būtisks jautājums gan nabadzības kvantitatīvā mērī̌sanā, gan kompleksu grūtību pieredzes kvalitatīvā analīzē. Nabadzības un sociālās atstumtības jēdzienu robežas ir neskaidras un lielā mērā pārklājas, tomēr sociālā atstumtỉba tiek uzlūkota kã plašāks jēdziens, kurā uzsvērta nabadzības sociālā dimensija un sociālo attiecību kvalitāte (Lāce, 2012). Nabadzības un sociālās atstumtības daudzdimensionālā izpratne ir balstìta uz skatijumu, ka nabadzība un sociālā atstumtība ir dažādu resursu deprivācija, kas nelauj dzīvot tādu dzivi, kādu sabiedrības 
vairākums pienem par normālu. Kompleksa pieeja nabadzības dimensiju izpētē ietver ienākumu nepietiekamību, materiālo deprivāciju un psiholoğisko labbūtỉbu (Walker, 2014, p. 21). Daudzdimensionālajā pieejā tiek ṇemta vērā arì veselïba un pieeja pakalpojumiem (Whelan \& Maitre, 2012, citēts pēc Walker, 2014), pieeja tiesībām, iespējām un resursiem (Todman et al., 2009, citēts pēc Walker, 2014), kā arī mājokḷa un apkaimes apstākḷi (nabadzīgāki cilvēki parasti dzīvo degradētās un nedrošās apkaimēs) (Walker, 2014). Visi šie ierobežojumi ir savstarpēji saistīti un pastiprina cits citu, kavējot pilnvērtīgi iekḷauties sabiedrības dzìvē (piemēram, saṇemt atbalstu, informāciju vai izmantot kontaktus, kas palīdzētu atrast darbu). Jāṇem vērā arì nabadzības psiholoğiskā dimensija - kā sabalansēt visas vajadzỉbas (savas, ğimenes locekḷu, draugu, darba devēja), ja ir nepietiekoši resursi. Uz deprivāciju balstita nabadzības izpratne pievēršas arī rīcībspējas trūkumam un dažādu kapitāla formu trūkumam (Ansari et al., 2012; Hick, 2014). Gan nabadzība, gan sociālā atstumtỉba ir saistitas ar zemu dzives standartu (resursu, tiesību, labumu un pakalpojumu nepietiekamību), kas nopietni ierobežo cilvēka iespējas darboties ekonomikas, sociālajā, kultūras un politikas laukā (Levitas, 2007, citēts pēc Bak \& Larsen, 2015). Šãda kompleksa pieeja ir izmantota pētijjumā, kurā veikti plaši aprēḳini par ekonomisko ievainojamību un tās saistību ar sociālo kohēziju, izmantojot Eiropas dzìves kvalitātes pētijuma datus (Whelan \& Maître, 2005b). Pētnieki secinājuši: kaut arī ekonomiski ievainojamu personu ir vairāk ekonomiski nabadzīgos iedzivotāju klasteros, tomēr asākas atstumtības problēmas izjūt iedzīvotāji ekonomiski turīgākos klasteros. Tas lielā mērā apstiprina tēzi, ka būt trūcīgam starp bagātiem ir grūtāk.

Kopsavelkot materiālā nenodrošinātība un sociālā atstumtỉba tiek operacionalizētas izmērāmos rādītājos, lai izmērītu to izplatību sabiedrībā un izstrādātu sociālās politikas instrumentus, kas to mazinātu un ḷautu noteikt kritērijus, kuros gadījumos kādi sociālās aizsardzības pasākumi būtu piemērojami. Kvantitatīvajiem skatījumiem tomēr ir viens būtisks trūkums - tie savā veidā nostiprina nabadzības stigmatizāciju, neņem vērā grūtỉbās nonākušo cilvēku pašcieṇu, kā arî šādā pieejā trūkst individuālo dzives situāciju dziḷas izpratnes un grūtībās nonākušo cilvēku pašu redzējuma.

Nabadzības materiālās, sociālās, psiholoğiskās sekas ikdienas pieredzē un to, kāda ir trūkuma subjektīvā nozīme,_-šos retāk pētîtos jautājumus var izprast tikai ar kvalitatīvām pētijumu metodēm (Fahmy \& Pemberton, 2012). Arī R.Volkers uzskata, ka nabadzības izpētē vairāk jāṇem vērā nabadzības psiholoğiskā dimensija, sevišḳi nabadzības un kauna saistība. Autors uzskata, ka tieši kauna dziḷāka izpratne varētu palīdzēt izskaidrot nabadzības noturīgumu un tās novēršanas politiku zemo efektivitāti. Tiek uzskatîts, ka sabiedrība ierosina kaunu un indivìds to akceptē un pieredz kā spēcīgu negativvu emociju, kas rada bezspēcības un sociālās atsvešināšanās sajūtu, kas kopumā atnem rīcibspēju (Walker, 2014). Ar nabadzỉbu saistītais kauns ir seviški intensīvs individuālistiskās un uz tirgu orientētās sabiedrībās, kurās cilvēka ekonomiskā veiksme nosaka personisko identitāti un sociālo statusu. Kaut arī nabadzības materiālās izpausmes ir loti atšḳirīgas valstīs ar dažādu labklājības līmeni, nabadzības subjektīvā uztvere ir lïdzịga - cilvēki nevar dzīvot atbilstoši savām un citu gaidām un priekšstatiem par normālu dzìvi. Nabadzības pieredzei raksturīga sajūta ir nespēja būt labiem partneriem, vecākiem, draugiem, pilsoṇiem (Walker, 2014; Fahmy \& Pemberton, 2012). Noteikti varu piekrist R.Volkeram (2014), ka nabadzìbas raksturs un pieredze ir sociāli konstruēti un pamatā visur tos nosaka morāles spriedums, kas materiālo resursu esamību saista ar sociālajām gaidām.

Personiskās pieredzes un balss nozīme kḹst svarīga arī skatījumā uz nabadzību kā cilvēktiesību jautājumu, kur pašcienai un varas attiecībām ir ierādīta svarīga loma. Pašcieṇas (dignity) svarïgums ir saistits ne tikai ar nabadzības riska sliekšna un sociālās aizsardzības minimuma noteikšanu, bet arī ar tādu pieeju pakalpojumu un palïdzìbas sniegšanā, kas nepazemo palīdzības saṇēmējus. Šis jaunais ietvars uzsver spēju stiprināšanu (empowerment) un līdzdalību, nediskriminēšanu un vienlīdzību (Walker, 2014). Šāds skatijums sasaucas ar ebreju filozofa Avišai Margalita (Avishai Margalit) skatījumu par cienijjamu sabiedrību (decent society) - cienijjama sabiedrība ir tāda, kuras institūcijas nepazemo to pakḷautībā esošos cilvēkus un kuras pilsoṇi nepazemo cits citu. Cienijamā sabiedrībā ir iespējams dzīvot bez pazemojumiem un ar cienu (Margalit, 1996, citēts pēc Rasnača \& Niklass, 2013).

Tomēr salīdzinoši maz ir pētijumu, kuru autori aplūko personisko pieredzi par dzivi ar ierobežotiem lỉdzekḷiem un izturas jūtigi pret pētijuma dalībnieku pašcienu. Eldins Fāmī (Eldin Fahmy) un Saimons Pembertons (Simon Pemberton) pētījumā par nabadzību un sociālo atstumtību Lielbritānijas laukos parāda grūtỉbas, ar kurām ikdienā saskaras intervētie cilvēki, un nabadzības stigmatizējošās sekas. Piemēram, publiskās administrācijas pazemojošo sistēmu, kas palīdzības sniegšanu pasniedz drīzāk kā labdarības dāvanu vai disciplinējošu varu nekā cilvēka pamattiesības uz sociālo aizsardzību. Pētnieki arī parāda spēcīgo subjektīvo vainas, kauna un bezvērtības apzinu, kas sasaucas ar citu pētnieku novēroto (Fahmy \& Pemberton, 2012; Martilla et al., 2013). Tajā pašā laikā pētnieki turpina lietot zinātniskajā literatūrā plaši pieņemtos nabadzības un sociālās atstumtības jēdzienus, kaut arī atzīst tos par stiơmatizējošiem. Savukārt Zviedrijas zinātnieku komanda Anneli Martilas (Anneli Marttila) vadībā ir pētijusi ilgsstošos sociālās palīdzības saṇēmējus Stokholmā un viṇu dzives gājumu. Pētnieki secina, ka gandrìz visiem ir viena vai divas pamatproblēmas (problēmas vecāku ğimenē, mācišanās problēmas, mentālās veselības problēmas u.c.), kuras nav tikušas pienācīgi risinātas, sekmējot lejupejošas spirāles veidošanos un grūtību aku mulāciju dzives gaitā (Marttila et al., 2013). Analizējot personiskās stratēĝ́ijas un pretestỉbu grūtību akumulācijai, pētnieki secina, ka intervētie cilvēki 
mēĝina risināt savas problēmas un saglabāt kontroli pār savu dzìvi, kā arī ir saṇēmuši individuālus pakalpojumus un palīdzību. Diemžēl tā ir bijusi pārāk îslaicīga un fragmentāra, lai būtu efektīva. Pētnieku ieskatā palīdzībai un atbalstam būtu jābūt ilgsstošam, personalizètam un vispusīgam, vienlaicīgi gan uzlabojot labklājību un pašvērtējumu, gan sniedzot iespēju iegūt tālāku izglìīibu un veicināt nodarbinātību. Šo pētijumu raksturo arì ḷoti jūtỉga attieksme pret pētijuma dalïbnieku pašcieṇu un subjektīvo pieredzi, nabadzības un sociālās atstumtības jēdzieni praktiski netiek lietoti, tādā veidā neturpinot pētījuma dalībnieku stigmatizāciju (Marttila et al., 2013).

Šajā rakstā lietošu Karstena Kronborga Baka (Carsten Kronborg Bak) un Jergena Elma Larsena (Jorgen Elm Larsen) skatijumu uz nabadzību kā sociālās škiras (strukturālu nosacỉjumu) un individuālās biogrāfijas kombināciju (Bak \& Larsen, 2015). N̦emot vērā A. Martilas un kolēğu pieeju, pievērsīšu uzmanību pētijuma dalībnieču pamatproblēmām un grūtību akumulācijai dzīves gaitā. Ievērošu daudzdimensionālu skatijiumu uz nabadzību un sociālo atstumtību, pievēršot uzmanību ienākumiem, materiālajiem apstākḷiem, mājokḷa apstākḷiem, sociālajai iekḷautỉbai, pieejai pakalpojumiem un resursiem, rīcībspējai un psiholoğiskajai labbūtībai. Pievērsišu uzmanību arī cieņas un pašcienas jautājumiem.

\section{Grūtību personiskās pieredzes izpētes metodologija}

Pētijums veikts valsts pētijumu programmas «SUSTINNO 2014-2017» ietvaros. Pētījuma laikā 2015. gadā tika veikta reprezentatīva Latvijas iedzīvotāju aptauja ( $n=2007)$ un ierakstītas 25 dzīvesstāsta intervijas ar cilvēkiem, kuri pārstāv dažādas ievainojamas sociālas grupas un kuriem ir atšķiirīgas grūtību pieredzes (pensijas un pirmspensijas vecuma cilvēki, invalīdi, bezdarbnieki, strādājošo nabadzībai pakḷauti cilvēki, viena vecāka ǵimenes, daudzbērnu ǵimenes, jaunieši ar zemu izglìtības līmeni). Biogrāfiskā metode ḷauj padzilịnāti aplūkot grūtībās nonākušo cilvēku ikdienas dzives pieredzi, personiskās izvēles dzives gaitā, ğimenes un plašāku sociālo kontekstu, l̦auj analizēt ciešo un vājo sociālo saišu lomu, resursu pieejamību un rīcībspēju to izmantojumā, kā arī lauj izprast sociālās palīdzības sanēmēja skatpunktu un sanemtā atbalsta pietiekamību ievainojamības pārvarēšanai. Jāatzīmē, ka atseviška pētījuma vērts ir jautājums par tiem cilvēkiem, kuri atrodas tuvu nabadzības riska līnijai vai nekvalificējas sociālās palīdzības un pakalpojumu sanemšanai, bet kuriem atbalsts grūtỉbu pārvarēšanai būtu nepieciešams un lautu situāciju normalizēt ar mazākiem ieguldijumiem no valsts puses, nekā tas būtu tajā brīdī, kad krīze jau ir smaga un ilgsstoša.

Lai padzilināti izpētītu personīgo pieredzi, pētijumā tika iesaistìti arī studenti, veidojot ciešāku sasaisti starp zinātni un augstāko izglìtību.
Dzivesstāsta intervijas ierakstijuši projekta pētniece Anžela Jurāne-Brēmane, sociolog̛ijas maǵistra studiju un kultūras un sociālās antropoloǵijas bakalaura un maǵistra studiju studenti 2015. gadā, kā arī dažas intervijas student veikuši 2016. gadā. Intervēto cilvēku izvēlē kritērijs bija sastapšanās ar grūtiem materiāliem apstākḷiem un iespēja tikt paklautiem nabadzības un sociālās atstumtības riskam. Kopumā ierakstītas un mācību procesā analizētas vairāk nekā 40 dzivvesstāsta intervijas, bet projekta datubāzē iekḷautas tikai tās intervijas, kuru dalībnieki ir piekrituši savu stāstu izmantot arī pētỉjuma vajadzībām.

Šajā pētijumā padziḷinātai analīzei izvēlēti četru sieviešu dzìvesstāsti, kuru stāstîtājām ir nepabeigta pamatizglìtība vai nepabeigta vidējā izglìtîba, divi vai vairāk bērnu un komplicētu partnerattiecību pieredze (partnera alkohola atkarība vai vardarbība ğimenē). Lai nodrošinātu pētỉjuma dalībnieču anonimitāti, analīzes aprakstā ir minēts tikai dalībnieču vecums, ǵimenes stāvoklis, bērnu skaits un vecumgrupa, pētījuma dalībniecēm pieškirti pseidonīmi, nav minēti citu personu vārdi, kā arī netiek norādītas citas identificējošas pazīmes. Piemēram, minēts tikai dzīvesvietas tips, nodarbošanās sektors u.tml. Atseviški dzives apstāklu un grūtību raksturojumi tiek sniegti, taču tie visumā raksturo tipiskās iezīmes līdzīgās situācijās nokḷuvušu sieviešu pieredzē.

Vispirms sniegšu vispārīgu pētijuma dalībnieču situāciju raksturojumu. Divas pētijjuma dalībnieces (turpmāk saukšu vinas par Annu un Mariju) dzivo ar partneriem, vienai ir trīs skolas vecuma bērni, un otrai ir četri pirmsskolas vecuma bērni, abas nestrādā algotu darbu. Divas pētijuma dalībnieces (turpmāk saukšu vinas par Ritu un Lindu) bērnus audzina vienas, vienai ir divi, un otrai ir pieci bērni, abām bērni ir pirmsskolas un pamatskolas vecumā. Abas strādā par apkopējām, jo šo darbu var savienot ar rūpēm par bērniem, kaut ari tas ir maz atalgots un nelauj pakāpties virs nabadzības riska sliekšña. Ciematos dzīvojošajām pētijjuma dalībniecēm (Annai un Lindai) piemājas saimniecỉba ir būtisks atspaids, kā arī abas sievietes izmanto iespējas veikt dažādus gadỉjuma darbus, lai uzlabotu g̣imenes materiālo situāciju. Tikai vienai sievietei no četrām ir bijusi laimīga bērnība un pašas izveidotā ǵimene balstās uz stabilām, ilgsstošām partnerattiecībām. Šì ǵimene ir tipisks krīzes un kredītu ietekmētas dzives piemērs. Pārējo trīs sieviešu dzīves gājums parāda sakarību, kas konstatēta arī citos Eiropā veiktos pētijumos, - vecākiem ar zemu izglìtỉbu arī bērni atkārto to pašu trajektoriju (Peruzzi, 2015), kā arī vecāku disfunkcionāla g̊imene negatīvi ietekmē bērnu dzives tālāko trajektoriju (Marttila et al., 2013). Biogrāfiskā pieeja lauj saskatìt izcelsmes ǵimenes sarežğîito attiecību un komplekso problēmu graujošo iespaidu uz sieviešu tālāko dzìvi. Sievietes bērnībā vai agrā jaunībā pieredzējušas rūpju un atbalsta trūkumu, nolaidīgu attieksmi un vienā gadījumā arì ilgsstošu vardarbību pret sevi kā bērnu. Rezultātā sekojusi pāragri uzsākta 
patstāvīga dzive, ko raksturo zemi izglitiibas sasniegumi, destruktivvas partnerattiecības un agras grūtniecības, kā arī vienā gadỉjumā ir pamats domāt par zemām dzīves prasmēm kopumā.

\section{Nabadzibas}

personiskā pieredze

\section{GRŪTİBU AKUMULĀCIJA UN EKONOMISKĀ KRĪZE. ANNAS STĀSTS}

Annai ir 43 gadi, viņai un virram ir trīs bērni pamatskolas un vidusskolas vecumā. Vini dzīvo ciematā, kas atrodas tālu no Rỉgas, bet tuvu republikas nozīmes pilsētai. Trīsistabu dzivoklis iegādāts uz kredìta, nav remontēts un ir pārāk šaurs piecu cilvēku ğimenei. Dārzā Anna izaudzē aug̣̣us, ogas un dārzenuus, tādēl vasarās veikalā jāpērk tikai piena produkti, maize un gạla. Annai ir vidusskolas izglìtỉba, kaut arī noslēguma eksāmeni nav nokārtoti. Vina ir strādājusi vienkāršus darbus, ilgstoši bijusi sekretāre vīra uzṇēmumā. Pašlaik ir bez oficiāla darba, jo vīra biznesam kopš krīzes iet arvien sliktāk. Dažas stundas nedēlā piestrādā par aukliti, lai ğimenei būtu kādi papildu ienākumi. Vīrs iebilst, ja viṇa ārpus mājas strādātu ilgākas darba stundas, jo viṇš nevēlas uzṇemties mājas pienākumus un rūpes par bērnu ikdienas gaitām. «Treknajos gados» likās, ka dzive strauji iet uz augšu, pēc otrā bērninaa piedzimšanas ğ̣imene panēma kredītu un iegādājās dzìvokli. Tomēr drīz viens pēc otra sekoja divi kritiski notikumi, kas radija ğimenes dzivē lejupejošu spirāli. Viens no bērniem smagi saslima, viṇa ārstēšanai ǵimene iztērēja visu summu, kas bija atlikta dzīvokla remontam. Bērninš nomira. Virs sāka dzert, jo citādi neprata tikt galā ar bēdām. Drīz sekojošā ekonomiskā krīze negativi ietekmēja jomu, kurā vinšš strādāja, viṇa uzṇēmuma apgrozijums strauji saruka. Viniem tika pieškirts trūcīgas ğimenes statuss. Vỉram ir grūti pārdzīvot to, ka viṇš nespēj pietiekoši apgādāt savu g̛̣imeni. Reizēm Anna ir optimistiski noskaṇota par nākotni, bet dažkārt neredz nekādas iespējas atrisināt esošās problēmas, kamēr vïrs turpina dzert, savukārt viṇa nevar savienot rūpes par bērniem ar kvalifikācijas iegūšanu, kas nepieciešama pietiekoši labi atalgota darba iegūšanai.

Annas stāsts reizē ir un nav tipisks daudzām krīzes skartām ğimenēm, kuras ekonomikas sabrukuma dēḷ nespēj savilkt galus un kurām mājokḷa kredīts situāciju padara patiešām smagu. Situāciju pasliktina iepriekš piedzìvotais bērna zaudējums, kuram vīrs emocionāli netiek pāri, nomaḷā dzīvesvieta un abu vecāku kvalifikācijas trūkums (vìram kā jau daudziem nelikās būtiski pabeigt bakalaura studijas, jo, būdams labs speciālists savā jomā, naudu varēja nopelnīt tâpat; savukārt Anna savulaik nenokārtoja vidusskolas eksāmenus veselïbas problēmu dēḷ, tāpēc nevarēja
1 Lïdzịgā situācijā, piepasliktināššnos, nonāe liels skaits ğimenu, tādè Labklājibas ministrija uzsāka attiecịgu grozijum sagatavošanu. Tomër Sociălo pakalpojumu un sociàlās palidzzibas sanemšana likuma 5. panta grozijumi par to, ka klienta materiālo resursu novērtēšanā valsts ğimenes pabalsts netiek uzskatits par ienākumiem, tika pienememti tika gadu vēlāk-2017.gada 12.janvärī-un stājās spēka 2017. gada 9. februârî (Labklājibas ministrija, 2017). tikt uzṇemta augstskolā un profesiju neieguva). Dzīvesvieta ciematā izvēlēta kā mierīga, zaḷa un droša vide, kur augt bērniem. Tomēr ekonomisku grūtibu brīiñ ǵimene kḷuvus par apstākḷu kịlnieci-attālums līdz tuvākajai pilsētai un galvaspilsētai škir no pieejas plašākām iespējām un pakalpojumiem (izglītībā, nodarbinātībā, veselības aprūpē). Anna nav izmantojusi Nodarbinātības valsts ağentūras sniegtās apmācības, jo lietvedības pamatus vina zina, grāmatveža palīga kvalifikācija viṇu neinteresē, bet interesēm un dotībām atbilstošas apmācību iespējas dzivesvietas tuvumā netiek piedāvātas. Annai attālums ir kluvis par nopietnu škērsli, lai iegūtu profesionālu kvalifikāciju sev interesējošā jomā (nav, kas pieskatîtu bērnus, un nav arì naudas, lai iegūtu kvalifikāciju tālu no dzìvesvietas, pat ja to piedāvātu bez maksas segt cela un dzivošanas izdevumus ǵimene nevar atḷauties) Savukārt bez kvalifikācijas viṇa var atrast tikai zemu atalgotu darbu, kur ieguvumi ir mazāki nekā ar darbu saistītās izmaksas (tai skaitā nemonetārās - mazāk laika darbam dārzā, mazāk laika pilnvērtīga un garšiga èdiena gatavošanai pieciem cilvēkiem, mazāk laika mājas un bērnu aprūpes pienākumiem). Jāatzīmē, ka 2016. gada sākumā līdz ar ğimenes valsts pabalsta apmēra pieaugumu ğimenes ienākumi izrādijjās par dažiem eiro lielāki nekā trūcīgas ğimenes statusa iegūšanai noteiktie ienākumi uz cilvēku mājsaimniecībā. G̦imene zaudēja trūcīgas ğimenes statusu un līdz ar to mājokḷ pabalstu, kas ziemas mēnešos bija izškirošs apkures izmaksu segšanai, kā arì bērniem brīvpusdienas skolā, kas bija loti nozimīgs atvieglojums, lai ğimene savilktu galus ikmēneša tēriṇiem ${ }^{1}$. Annas ǵimene un līdziggā situācijā nokḷuvušas ǵimenes tālāk sastapās ar nevienlīdzīgām iespējām valsts atbalsta sanemšanai. Maznodrošinātā statusa sanemšanas kritērijus katra pašvaldība nosaka pēc saviem ieskatiem, un dažādās pašvaldībās ienākumu slieksnis maznodrošinātā statusa saṇemšanai ievērojami atškiras - tie var būt 143 eiro mēnesì kā Neretā un Nìcā, bet var būt arī 36o eiro mēnesī kā Mālpilī un Salaspilī (Labklājỉbas ministrijas, 2016). Lìdz ar to ğimenēm ar līdzịgu materiālo situāciju un problēmām ir loti atškiirīgas iespējas sanemt sociālo atbalstu. Iespējas ir pilnībā atkarīgas no dzīvesvietas, nevis no vajadzībām. Annas ớimenei nepaveicās, jo vinu pašvaldībā maznodrošinātā statusa iegūšanai ienākumu slieksnis ir tikai nedaudz augstāks kā ienākumu slieksnis trūcīgā statusa iegūšanai. Tā nu ğimenei bija jārisina grūtības pašu spēkiem.

Annas pieredze palīdz labāk saprast grūtību veidošanās komplekso raksturu un sarežğîijumus to risināšanā. G̣imenei, saskaroties ar vairākām smagām problēmām ìsā periodā - vispirms zaudējot bērnu un pēc tam ekonomiskās krīzes rezultātā piedzìvojot arī būtisku ienākumu kritumu -, ir 
nepieciešami papildu resursi grūtību pārvarēšanai, un ğime- $\quad 2$ Analizējot lìdzekḷu sadalīnes kā sistē nes kā sistēmas darbỉba tiek izjaukta. Iepriekš vairāk uzsvēru ienākumu līmeṇa vai pašvaldības rocības saistību ar sociālā atbalsta sanemšanas iespējām, tomēr pirmām kārtām izški roša loma ir citiem personas rīiibā esošiem resursiem, kā spējai psiholoğiski pārvarēt dzives triecienus, ğimenes atbalstam un plašākam atbalsta tỉklam, galu galā arī spējai pienemt atbalstu un palīdzību. Ne mazāk svarīga loma ir kultūrā saknotiem priekšstatiem, piemēram, par dzimumu lomām. Annas vīrs, kā l̦oti daudzi vīrieši Latvijā, nespēj pieṇemt profesionāla psihologa palīdzibu zaudējuma traumas dziedināšanai, lỉdz ar to viň̌ atsakās no loti būtiska resursa grūtỉbu pārvarēšanā. Tradicionālais priekšstats par vīrieti kā stipro dzimumu un ğimenes apgādnieku nelauj vinamam atzìt savu ievainojamïbu un pienemt jumu pašvaldibu sociālajiem pabalstiem 2015. gadā jāuzsver, ka lauku pašvaldìbās atbalsta iespējas jebkurà gadijumā ir mazākas nekā pilsētās, jo sociālajai palìdzībai un pakalpojumiem atvēlêtie līdzekḷi ir mazāki uz lielāku skaitu cilvēku (turklāt palidzibu sanememošo bērnu skaits laukos 2015. gadā bija divreiz lielāks nekā pilsētās (Bela, 2017; Labklājibas ministrijas, 2016).

palīdzību, kā arī rada papildu psiholoğisko slodzi situācijā, kad nav iespējams pildìt ğimenes apgādnieka lomu atbilstoši savām un sabiedrības gaidām. Situāciju vēl pasliktina alkohola īpašā nozīme postpadomju telpā, kurā tradicionālajos priekšstatos par «īstu virieti» ietilpst arī spēja lietot stipro alkoholu lielos daudzumos. Pētnieki ir novērojuši, ka pārmērīgs alkohola patēriņš vīišķỉbas apliecināšanai sevišḳi tiek izmantots situācijās, kad nauda un vara kā tradicionālie vīriškīibas atribūti nav pilnībā sasniegti (Hinote \& Webber, 2012, citēts pēc Gātere, 2017). Iespējams, šajā kultūrā ietilpst arī priekšstats, ka issti vīri, kad viniem ir grūti, dzer, nevis apmeklē psihologu. Rezultātā problēmas tikai padzilinās un ğimene vairs nefunkcionē kā sistēma, kḷūst disfunkcionāla. Vienlaicīgi Annai, tāpat kā loti daudzām sievietēm līdzịgā situācijā, laulibas šḳiršana nav pieņemams risinājums. Svarīga ir arī laulibas emocionālā dimensija - mīlestība un piekeršanās, kā arī morālā dimensija - solījums būt kopā priekos un bēdās, bagātībā un nabadzỉbā, veselībā un slimībā. Arī tradicionālie priekšstati sievietei piešķir ğimenes pavarda sargātājas lomu, un atkāpe no šis lomas iedarbina kauna un vainas izjūtas. Lìdz ar to sieviete centīsies atbilst ğimenes pavarda sargātājas lomai un nodrošināt bērniem pēc iespējas normālu ikdienu pilnā ğimenē tik ilgi, cik tas būs iespējams.

Jāatzìmē pieejama valsts atbalsta trūkums, lai ğimene varētu atkal kḷūt funkcionāla, pirms vēl ir iestājusies ḷoti smaga krīze. Lielākoties pašvaldību sociālo pakalpojumu grozs ir tik plāns, ka sociālo darbu ar ǵimeni var atḷauties tikai ḷoti kritiskos gadijjumos, kad vecāki nespēj pildìt savas funkcijas un draud bērnu izṇemšana no ǵ̛imenes². Savukārt valsts finansētus psihologa pakalpojumus var sanemt tikai vardarbībā cietušas sievietes ar bērniem. Kultūras priekšstatos un cilvēka psiholoğijā rodamus šķērš̌lus, kas ierobežo vai kavē izmantot pieejamos resursus grūtību pārvarēšanai, varbūt ir pat grūtāk mainīt nekā sociālās palīdzības un pakalpojumu grozu un budžetu. Darbs ar psihologu, mainot uzskatus un attieksmes, šeit būtu ne mazāk svarīgs kā materiālā palīdzība, lai sasniegtu cerēto rezultātu un ǵimenei izdotos pārvarēt grūtības.

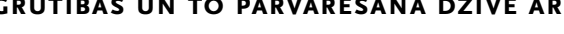

IEROBEŽOTIEM IENĀKUMIEM. RITAS STĀĀSTS

Ritai ir 31 gads, un vina viena audzina divus sākumskolas un pirmsskolas vecuma bērnus. Abas attiecības, kurās bērni dzimuši, ilgušas vien dažus gadus. No otrā bērna tēva Rita aizgājusi pēc tam, kad vinš̌ dzērumā kḷuvis vardarbīgs. Kritiskais notikums Ritas dzivē ir tēva nāve, kad meitenei bija tikai 16 gadi, tam sekoja skolas pamešana un patstāvigas dzives sākšana. Pirms gada Ritas dzive atkal apmeta kūleni-Ritas draugs vinu pameta, atstājot vienu ar bērniem, bez darba, bez iztikas lìdzekḷiem, mazpilsētā, kur viṇa nevienu nepazìst. Rita izmisumā vērsās pēc palīdzỉbas sociālajā dienestā, kur vinai atteica, pat neuzklausijjuši, jo vina neizskatoties nabadzīga. Krīzi palīdzēja pārvarēt relig̣iska organizācija, sniedzot materiālu un psiholoğisku palīdzỉbu, kā arī praktisku atbalstu sociālās palīdzỉbas nokārtošanai. Patlaban Rita strādā par apkopēju un oficiāli îrē dzīvokli no bijušā drauga, kurš devies pelnnā uz ārzemēm. Kaut arī apkopējas alga ir maza, tie tomēr ir pašas gūti ienākumi un šo darbu var savienot ar abu mazo bērnu aprūpi, kas pilnỉbā gulstas uz Ritas pleciem. Pārtikas pakas un zupas virtuve ir pagātne, tomēr drēbes joprojām ir tikai no lietoto preču veikala, kur Rita tās iegūst apmainā pret palìdzību. Rita vēlètos pabeigt vidusskolu un apgūt kādu profesiju, lai varētu strādāt labāk atalgotu darbu. Mazpilsēta ir laba vieta dzīvošanai, tomēr ne tālākai izglitīibai. Kamēr bērni ir tik mazi un naudas tik tikko pietiek, lai savilktu galus, un kamēr Ritai nav neviena, kas varētu palīdzēt pieskatìt bērnus vai atbalstìt materiāli (mamma dzìvo tālu, kā arī ir azartspẹlu atkarīga un viņai pašai vajadzìga palïdzỉba), vinai nav iespējas savienot darbu un rūpes par bērniem ar tālāku izglìtošanos. Pagaidām ir tikai sapni, ko Rita darīs, kad bērni paaugsies.

Ritas stāsts labi parāda agrīnu kritisku notikumu izšķirošo lomu un atbalstošu pieaugušo nozīmi pusaudža vecumā, kā arī grūtỉbu akumulāciju dzives gaitā un sociālā atbalsta tīkla svarīgumu. Palikusi ar māti, kura acīmredzot nespēja pārdzīvot dzìvesdrauga zaudējumu un uzṇemties rūpes par sevi un meitu, 16 gadu vecumā Rita ir spiesta uznemties atbildību par savu dzīvi pati. Izglītỉbas iegūšana nešķiet svarīga, un lỉdzās nav neviena pieaugušā, kurš pārliecinātu par profesijas nozimigumu un sniegtu atbalstu tās iegūšanā. Tagad Ritai ne tikai ir jātiek galā ar sevi, bet arī jāspēj rūpēties par diviem maziem bērniem. Stāsts parāda arī apnēemìbu risināt grūtības un efektīvu saṇemtās palīdzības izmantošanu, lai tās pārvarētu. Vajadzības gadījumā vina meklē palīdzību, ko arī sanem, un cīnās, lai uzlabotu savus dzives apstāklus. 
Ritai un arī citām intervētajām sievietēm ir dažādas izdzìvošanas stratẹǵijas, kas ierobežotu resursu apstākḷlos prasa rūpigu aprēḳinu un izdomu. Rita un Marija visgrūtākajos dzīves mēnešos ir saṇēmušas pārtikas pakas un iespēju ǵimenei ēst bezmaksas zupas virtuvē. Ēdiena gatavošana, ja iespējas ir pieticiggas, ir nogurdinošs uzdevums visām, jo ir grūti izdomāt veselīgu un garšìgu ēdienu, kas katru dienu neatkārtojas. Annai un Lindai dzive laukos sniedz dažas priekšrocības - daudz ko var izaudzēt dārzā, un Linda, ar kuru iepazīstināšu vēlāk, pat tur mājputnus un kazas, lai veikalā nebūtu jāpērk gaḷa un piens. Ritai un otrai pilsētniecei Marijai dārza sniegtu iespēju nav. Visas intervētās sievietes stāsta, ka drēbes un mēbeles pamatā iegādājas lietotas. Gimenē, kur bērni jau ir skolēni un pusaudži, saspiestība ir nopietna problēma - katram gribas arī privātu dzives telpu, bet tādas nav pat vecākiem. Piemēram, Annas ǵimenē abiem dēliem jādala mācībām viens galds, jo otram galdam vienkārši nav vietas. Visām sievietēm ir loti pieticīgs radu un draugu atbalsts bērnu aprūpē un grūtību pārvarēšanā (vai kā Lindai - nav radu un draugu, kas varētu atbalstīt). Vienlaicīgi visām ir tā saukto vājo sociālo saišu loks, kur dažreiz iespējams saṇemt kādu praktisku palīdzību un atbalstu, kā arì aiznemties 5-15 eiro lïdz pabalstu sanemšanas dienai. Anna ir vienigā, kura var aizṇemties no tuviem radiniekiem. Marija aiznnemas no g̛imenes asistentes, kaut gan arī vecāki reizēm sniedz palīdzịu roku, nopērkot drēbes vai apavus bērniem. Linda un Rita nepieciešamïbas gadijumā aizṇemas no kaimiṇiem un paziṇām, kuri viṇas saprot, jo paši dzivo pieticīgi, un «tā mēs palīdzam viens otram, kā nu varam» (Linda). Viṇām nav radinieku sniegtas materiālas palīdzỉbas. Ritu reizēm praktiski atbalsta tuva radinieka sieva, kas dzivo citā novadā,-vinas ciemojas viena pie otras, dodas nelielās kopigāas ekskursijās, kas ḷauj izrauties no mājas, un par saviem līdzekḷiem Rita to nevarētu.

Ritai un Marijai piederība reliǵiskai kopienai ir nozīmīgs atbalsta resurss. Pirmkārt, praktisks - pieeja pārtikai, lietotām drēbēm, lietotām mēbelēm un sadzives tehnikai. Marija pat dzivvokli ir atradusi ar draudzes palīdzību, jo neviens nevēlas izīrēt dzīvokli bezdarbnieku ğimenei ar četriem pirmsskolas vecuma bērniem, baidoties, ka viṇi nemaksās ìri un bērni var sabojāt dzīvokli. Par samaksu, ko Marija varēja aṭ̣auties, piedāvājumā bija tikai dzīvokḷi bez labierīcībām (malkas apkure, aukstais ūdens). Otrkārt, bet ne mazāk svarīgs - draudzes sniegtais morālais un emocionālais atbalsts. Tas ir ḷoti nozīmīgs, lai mazinātu sociālo izolāciju, kādā sievietes dzīvo, jo vināam nav ne laika, ne naudas sociālai dzīvei, kontakti ar radiniekiem ir pārtrūkuši vai ierobežoti. Piemēram, māminnu tikšanās draudzē ḷauj izrunāties savā starpā, un «paliek vieglāk» (Marija). Rita ar draudzes palīdzību ir izveidojusi kontaktus jaunajā dzīvesvietā, kur viṇa nevienu iepriekš nepazina un jutās ḷoti izolēta un nomākta, kad partneris vinu pameta. Ritas gadijjumā tieši draudzes locekḷi sniedza palīdzību krīzes brīiī, un tagad Rita palīdz sestdienas skolinas nodarbībās un dažādos citos darbinos, kas savukārt lauj justies kā devējai, nevis tikai nēmējai. Arī Linda ir saṇēmusi palīdzỉbu no reliǵiskas organizācijas, un tieši nenosodošā attieksme un beznosacijjumu palīdzība ir cēlusi vinas pašapziṇu un motivējusi meklēt iespējas sakārtot dzivi.

Medicīnas pakalpojumi un zāles ir nopietnākā problēma visām sievietēm. Kamēr statistika operē ar skaitḷiem par augstajiem pacientu līdzmaksājumiem Latvijā un grūtībām sanemt medicinas pakalpojumus, kad tie ir nepieciešami, šo sieviešu stāsti parāda dramatiskās izvēles, ar kādām sastopas cilvēki ar ierobežotiem ienākumiem tajā brīdī, kad ir veselības problēmas. Gan pašas, gan bērni mēdz slimot. Dažkārt ir jāizškiras, kurš apmeklēs ārstu, kuram taisīs analīzes un kuram pirks zāles. Parasti priekšplānā ir rūpes par bērniem, un par sevi sievietes rūpējas tikai smagos akūtos gadijumos. Kaut arī bērni var saṇemt bezmaksas medicinas pakalpojumus, izdevumi par zālēm tik un tā ir jāsedz no savas kabatas. Laukos speciālisti nav pieejami, un daži nav pieejami arī tuvākajā republikas nozìmes pilsētā. Sabiedriskais transports ir dārgs (turklāt ceḷ̌ panem visu dienu, kas strādājošām sievietēm savukārt nozīmē arī kavēt darbu), tāpēc galvaspilsētā Rīgā pieejamos speciālistus apmeklē tikai ḷoti nopietnas vajadzības gadỉjumā. Kaut arì teorētiski ir iespējams saṇemt kompensāciju par ceḷa izdevumiem, praktiski ši iespēja netiek izmantota.

Kaut arī dāvanas parasti literatūrā netiek minētas pie dzīves pamatvajadzībām, tomēr ikdienā tām ir svarīga loma sociālo saišu uzturēšanā - vārda dienās, dzimšanas dienās, Ziemassvētkos ir pienemts pasniegt dāvanas tuvākajiem śimenes locekliem un draugiem. Intervijās par svētku svinēšanu speciāli jautāts netiek, Marija ar Lindu ciemošanos un dāvanas nepiemin. Bet Anna un Rita stāsta par to, kā vinas ǵ̛imenei un draugiem dāvanas izgatavo pašas. Tas lauj uzturēt attiecības un justies piederīgām. Rita pat prāto, vai savu radošo talantu nepārvērst biznesa idejā.

Jāatzīmē, ka tikai raksta vajadzībām priekšplānā izvirzîts apkopojošs skatỉjums uz galvenajām grūtībām, ar kurām sastopas intervētās sievietes. Stāstos priekšplānā izvirziti galvenie ikdienas uzdevumi un sieviešu radošā pieeja situāciju risināšanā.

\section{BAŽAS PAR BĒRNU NĀKOTNI UN IZGLīTĪBAS}

\section{TRŪKUMA STRUPCEL,Š. MARIJAS STĀSTS}

Marijai ir 26 gadi, nepabeigta pamatskolas izglititiba un četri pirmsskolas vecuma bērni. Viṇas vecākā bērna tēvs patlaban atrodas cietumā. Arī pašreizējais partneris un jaunākā bērna tēvs ir bijis ieslodzijumā. Intervijas brīdī Marija un vinas partneris ir bez algota darba. Var nojaust, ka partnerim ir problēmas ar alkohola pārmērïgu lietošanu, bet Marija nedzer un nesen atmetusi 
arī smēḳēšanu. Gimene ïrē nelielu dzīvoklïti Rīgā. Viniem ir trūcīgas ğimenes statuss, un Marija sanem ğimenes asistenta pakalpojumu. Marija ḷoti cenšas normalizēt dzivii, jo baidās, ka viṇai varētu atṇemt bērnus. Viṇa grib būt laba mamma. No pieticīgā ǵimenes budžeta Marija sedz maksu vecākajam bērnam par vingrošanas (8 eiro mēnesī) un ang̣̣u valodas (12 eiro mēnesī) nodarbībām bērnudārzā. Viṇa baidās, ka viṇas rūpes par bērniem aprobežosies ar tîrišanu un ēst gatavošanu, ka vina nespēs atbalstìt bērnu talantu attistîbu un segtt izdevumus par ārpusskolas nodarbỉbām, kad bērni paaugsies. Vina arī nevar samaksāt par kopigu muzeja, Zooloğiskā dārza vai citu kultūras iestāžu apmeklēšanu, kas ir tik loti būtiski bērnu vispusigai attistỉbai. Marija ir bēdīga, ka valsts sedz tikai izdzivošanas vajadzibas, bet neinvestē bērnu attīstībā. Tomēr dzìvei galvaspilsētā ir savas priekšrocības-Marijai sabiedriskais transports ir bez maksas, un vina cenšas ar bērniem apmeklēt tos kultūras pasākumus, kuri ir par brivu. Marija gribētu pabeigt pamatskolu, bet vinai ir kauns mācities kopāa ar pusaudžiem.

Arī šajā pētijjumā iegūtie dati rāda, ka dzive ar ierobežotiem līdzekliem ierobežo noteiktu sociālu lomu izpildi atbilstoši sabiedrības gaidām un pieṇēmumiem (Fahmi \& Pemberton, 2012; Walker, 2014). Visas sievietes ir norūpējušās par to, vai ir pietiekoši labas mātes, un pārdzivo, ka nevar sniegt bērniem visu nepieciešamo. Varbūt Linda, kura vienīgā ir piedzivojusi patiešām traumējošu bērnību un par kuras attīstību nekad neviens nav rūpējies, mazāk uzsver bažas par savu bērnu nākotni un nespēju būt labai mammai, kas atbalsta bērnu izglītỉbu. Marija uztraucas, ka bērni var nesaskatìt jēgu mācīties, tāpēc ka mammai arì nav izglìtỉbas un viṇa tāpat izdzīvo. Vina arī uztraucas, ka nevarēs samaksāt par privātskolotāju, ja gadỉjumā bērniem skolā būs grūtības apgūt vielu tikpat ātri kā citiem. Marija nezina, ka skolēniem ir pieejami pulciṇi, par kuriem pašvaldību finansētās iestādēs Latvijā nav dārgi jāmaksā, turklāt trūcīgu un maznodrošinātu vecāku bērni no lïdzmaksājuma ir atbrīvoti. Ritas meita iet mūzikas skolā, un Annas meita dejo pašdarbības kolektīvā. Tomēr sievietēm un vinu ğimenēm lauku reǵiionos un mazpilsētās iespējas ir daudz ierobežotākas nekā galvaspilsētā vai lielākās pilsētās. Anna ḷoti pārdzīvo, ka var segt vienīgi izdevumus par tiem kultūras pasākumiem, ko bērni apmeklē kopā ar klasi (un pat tad bieži ir jāaizṇemas no radiem, jo neparedzētiem izdevumiem naudas nav). No sava lauku ciemata vini nevar doties uz tuvāko pilsētu, par galvaspilsētu pat nerunājot, lai visi kopā apmeklētu kino vai teātri. Kopš ǵimenei nav mašinas, viṇi arī nevar nekur aizbraukt ekskursijā. Vienīgi Rita stāsta, ka ceḷo kopā ar bērniem samērā regulāri, jo viṇas draugi no iepriekšējām dzīvesvietām vai radiniece atbrauc pakal, un tad visi kopīgi dodas kādā ekskursijā. Faktiski neviena no ǵ̛imenēm nevar pavadìt laiku kopā tādā veidā, kā to var vairums ğimenu, dodoties kopīgos braucienos, apmeklējot kultūras pasākumus, - tas viss ir tikai sapnis. Kopiga ēšana ārpus mājas intervijās nemaz netiek pieminēta, par tik ekskluzivu lietu sievietes pat nesapņo. Pamatotas ir bažas par atbalstu bērnu talantu attistìbai un izglìiibas sasniegumiem - ar ierobežotiem līdzekḷiem, sevišḳi laukos, iespēju ir daudz mazāk. Savukārt Marijas stāsts liek domāt par nezināšanu un informācijas trūkumu - gan par viṇas pašas izglìtības iespējām, gan bērnu ārpusskolas izglìtības iespējām.

Nepietiekams atbalsts un sliktāka situācija ǵimenēm ar bērniem lauku pašvaldībās atzìmēta arī citos pētỉjumos. Piemēram, pētijumos par bērnu nabadzību un sociālā riska ğimenēm Signe Dobelniece (2015) ar kolēǵiem ir konstatējusi, ka laukos dzīvojošās ǵ̛imenes ar bērniem atrodas dzilākā nabadzībā. Savukārt Labklājỉbas ministrijas pasūtitā apsekojumā par trūcigām daudzbērnu g̛imenēm cita starpā apkopota arī statistika par saṇemto palīdzību un pakalpojumiem, kas apliecina, ka tie pamatā ir vērsti uz izdzivošanas pamatvajadzību apmierināšanu un mazāk uz izaugssmi un attīstību (GfK, 2013).

\section{DZĪVES NORMALIZĀCIJA STĀSTİJUMĀ UN}

PRETESTīBa STIGMATIZĀCIJAI. LINDAS STĀSTS

Lindai ir 31 gads, nepabeigta pamatskolas izglitỉba un pieci bērni (dzivo kopă ar četriem, par vienu maksā uzturnaudu). Trim bērniem katram ir cits tēvs, jaunākajiem bērniem - viens. Divas reizes precējusies. Nevienas partnerattiecỉbas nav bijušas ilgstošas, Lindas vỉriešiem bijušas problēmas ar alkoholu un vardarbīgu rīcibu. Atzīst, ka arī pati ir bijusi vardarbīga. Tagad oficiāli škịirusies, jo vīrs meitas nav uzturējis, naudu tērējis par alkoholu un azartspēlēm, bet oficiāâās laulïbas dẹl Linda nav varējusi pretendēt uz sociālo palīdzỉbu, jo vīra alga formāli bija pietiekoša. Dzivo tajā pašā ciematā, kur dzimusi un augusi. Pašlaik strādā par apkopēju uz pusslodzi. Lai piepelnītos, audzē mazos dzīvniekus zosis, vistas, kazas, trušus, pīles - un piestrādā dažās zemnieku saimniecỉās. Par savu bērnibu stāsta, ka ir bijusi lieks bērns. Mātei nav bijusi vajadziga, jo, kad māte satikusi citu vīrieti, meita atdota vecvecākiem. Sista, ja nav izdarijusi, kas likts. Aiz bailēm no vecāsmātes vardarbỉbas 12 gadu vecumā neturpināja mācības skolā, kad pedagogi piedāvāja pāriet uz speciālo internātpamatskolu. Kopš 12 gadu vecuma strādā fermā, vecāsmātes vietā kopjot un slaucot 48 govis. Kopš 13 gadu vecuma fermā arī dzìvo. 17 gadu vecumā Lindai piedzimst vecākais dēls. Pēc tam seko virkne destruktīvu partnerattiecỉbu, kurās dzimst bērni, veikusi arì divus abortus. Pirmo reizi dzīvē Lindai ir drosme būt vienai, un vina atzisst, ka bez viriešiem dzive ir labāka. Tomēr Linda ir ḷoti vientuḷa, vinai nav draugu, nav arī laika un naudas, lai kaut kur aizietu. Vina atzīst, ka reizēm jūtas ḷoti nomākta. Vienlaicīgi viṇa ir apṇēmības pilna sakārtot savu dzīvi un izvirza sev mērḳus - šogad tā bija škirišanās un uzturnaudas nokārtošana, parādu atdošana. Nākošgad mērkịis ir nokārtot autovadītāja tiesỉbas, 
kāds pazina ir gatavs atdot Lindai savu veco mašinu. Dzīvojot laukos, mašina ḷoti atvieglotu sadzīvi un paplašinātu piepelnī̌sanās iespējas.

Faktiski Lindas stāsts ir vienīgais, ko nav iespējams izstāstīt, izvirzot priekšplānā mierīgu ikdienas dzīvi un grūtības pēc iespējas atvirzot otrā plānā. Stāsts ir pretrunu pilns, un viena atkāpe seko otrai, lēkājot no viena dzives posma uz otru, no viena notikuma uz citu. Attiecỉbu samezglojumi un sāpīgi konflikti kā īleni izspraucas cauri stāstam par pūlēm sakārtot dzīvi. Samezglojumi kā noklusējumi ir jūtami arī Marijas stāstā, viṇa koncentrējas uz tagadējiem centieniem veidot sev un bērniem normālu ikdienu, apejot pagātnes kritiskos notikumus, kuru akumulācija ir novedusi pie pašreizējiem sarežğijiumiem (piemēram, kādas ir attiecības ar vecākiem, kas notika pēc trešā mēǵininājuma pabeigt 9.klasi, kas ir pirmo trīs bērnu tēvi u.c.). Annai un Ritai dzives pieredze ir mazliet gludāka, vinas savus stāstus veido, aprakstot ikdienu un savu radošo pieeju pieticīgo resursu izmantošanā. Visas sievietes cenšas uzsvērt risinājumus, nevis grūtības.

Nabadzības vārds netiek lietots nevienā stāstā. Atstumtība gan tiek minēta trīs stāstos: kad Linda apraksta savu bērnïbu; kad Marija apraksta paziņu pieredzi, kuri nelūdz pabalstus, lai netiktu atstumti; kad Anna apraksta savas pūles nodrošināt bērniem visu skolai nepieciešamo, lai viniem būtu viss kā citiem un vini skolā netiktu atstumti. Priekšplānā tiek virzìts pozitīvais - gan ğimenes ikdienas dzīvē, gan savā darbībā, gan sadarbỉbā ar sociālo dienestu. Tikai stāstijuma vidū vai noslēgumā kādā teikumā starp citiem atklājas arī dzīves smagākā puse-esošo vai bijušo partneru alkoholisms, trim sievietēm bijusi arī vardarbỉbas pieredze (Lindas gadijumā ilgstoša un bieži abpusēja emocionāla un fiziska vardarbība).

Ar pazemojošu vai stigmatizējošu attieksmi no sociālā dienesta puses vismaz vienu reizi ir saskārušās visas, iznemot Annu. Subjektīvi izjustā attieksme ir līdzīga, kādu savā pētỉjumā identificē arī E. Fāmī un S. Pembertons (2012) Lielbritānijā - pabalsts tiek piešḳirts ar tādu attieksmi, it kā tā būtu labdarības dāvana no ierēdṇa personiskās kabatas, nevis cilvēka tiesības saṇemt palīdzību dzìves krìzes situācijās; palīdzības saṇēmēji tiek turēti aizdomās par ienākumu slēpšanu u.tml. Lindai vairākas reizes ir atteikta sociālā palīdzība. Vienreiz tādēl, ka viṇa bijusi pierakstìta vienā platībā ar vecomāti, kurai bija pietiekoši liela alga. «Tad bija tā no sociālajiem loti lieli pārmetumi. Tu tikai bērnus taisīt, valsts naudu saṇemt, strādāt nemaz negribi. [Pauze.] To es dzirdēju ne vienu vien reizi. Jo, jo, jo... [Pauze, nevar parunāt.]» (Linda) Tāpēc nākošajā lielajā dzīves krìzes brīdì vina ir sevišḳi pārsteigta par Pestī̌sanas armijas sniegto palīdzību: «Man tagad arī asaras acīs, kad es tagad atstāstu. Nevis atbrauca satrauktos bērnus paṇemt projām, bet vienkārši saveda visu, kas bija nepieciešams, tā. Es, man... vai patiešām tā man var vienkārši palīdzēt? Tāa atbraukt, kastes pilnas ar pilnịgi visu, ko vajadzēja, lai varētu mēnesi dzīvot, ne bēdu nezināt. I nezināju, kā pateikties vispār, loti tā kā neērti bija [caur asarām]. Bet pēc tam sāku domāt, kāpēc man ir jākaunas no tā?» (Linda) Viṇai ir grūti atrast vārdus, jo viṇa kopš bērnības ir jutusies mazāk vērtīga nekā citi un arī iepriekšējie lūgumi palīdzēt tikuši noraidīti. Lindas pieredzē beznosacỉjumu palïdzības saṇemšana ir kaut kas jauns, un pieredzētā epizode pamazām maina viņas dzivi. Izšķiroša loma ir sastaptai atbalstošai sociālajai darbiniecei, kura palīdz pārtraukt destruktīvas partnerattiecības, sakārtot formalitātes (tas aiznem aptuveni gadu), normalizēt ikdienu un būvēt jaunus nākotnes plānus. Kḷūt par palīdzības saṇēmēju ir grūti ne tikai Lindai. Sabiedrībā par normu tiek uzlūkots, ka pieaudzis cilvēks spēj pats parūpēties par sevi un saviem bērniem. Kultūrā pienemta vērtība ir būt devējam, nevis būt atkarīgam no citu palīdzības (Walker, 2014). Piemēram, Anna ilgi nav zinājusi, ka ar ğimenes ienākumu lïmeni var pretendēt uz sociālo palīdzību, un, tikai draugu mudināta, ir sākusi interesēties par atbalsta iespējām. Annas vīram sociālās palīdzības un sociālo pakalpojumu sanemšana ir smags psiholoğisks trieciens, jo skaidri norāda, ka viņš nepilda tradicionālo ğimenes apgādnieka lomu. Kā to raksturo Anna: «Nu, vīrs ir pavisam skeptisks, un vinš ir nikns uz visu pasauli. Vinš ir lepns, ka vinam ir trīs bērni, bet tai pašā laikā viņš jūtas gandrīz tā kā noziedznieks - a kam tad tev vajadzēja tos trīs bērnus, ka tu tagad pats netiec galā, un tas tāds .. jā.»

Kaut gan sievietēm góimenes apgādnieka lomas nepildīšana rada mazāku spriedzi, arī sievietes dalās pārdomās par to, vai ir atbalsta cienīgas un vai ir morāli tiesīgas kritizēt valsti par atbalsta nepietiekamību: «[..] lai tas dzīves līmenis mazliet, mazliet būtu augstāks, lai gan ko es varu prasìt, ja man pašai nav izglitīibas .. Tik daudz atkal, varbūt, ka, nu, es neesmu nodzērusies, un es neesmu slinka, man ir dārzs, un es viṇā strādāju, lai pabarotu ğimeni, un meklēju visu, visādas iespējas, lai mēs...» (Anna). Toties sievietes sāpīgāk uztver atbilstỉbu savām un sabiedrỉbas gaidām par mātes lomu. Visām sievietēm ir svarīgi stāstījumā parādīt savas pūles un centienus sakārtot savu dzīvi, lai nodrošinātu bērniem normālu ikdienu. Arī Linda uzsver, cik ḷoti ir mainījusies, kā cenšas un cik loti vinai sāp, ka kaimini vai citi cilvēki reizēm mēdz atgādināt par viṇas nopietnajām kḷūdām pagātnē. Savos stāstos sievietes lïdzsvaro objektivo grūtību aprakstu ar pozitivu paštēlu un savas rīcībspējas uzsvēršanu. Grūtỉbu aplūkojums iedarbina sabiedrības uzturētās kauna jūtas par dzīvi ar trūcīgiem lídzekliem un liek skali atzìt savu nespēju dzivot atbilstoši vairākuma pieṇemtajam dzìves standartam. Tāpēc savas rīcībspējas uzsvēršana, meklējot izeju un risinājumu svarīgāko dzives vajadzibu apmierināšanai, un pozitiva paštēla veidošana (parādot sevi kā strādīgas sievietes, kuras cinās ar savu slinkumu un meklē dažādas iespējas uzlabot ğimenes materiālo situāciju, nelieto atkarību izraisošas vielas un cenšas būt labas mātes) ir tik loti svarīga, lai varētu izstāstìt savu stāstu ar pašcieṇu, kuru uzturēt ir tik būtiski katram cilvēkam. 
Noslēgums: starp cerībām un bezcerību

Analīze rāda, ka strukturālie nosacijumi (kā ekonomiskā krīze, zems minimālās algas limenis valstì, izglitîbas un nodarslānim joprojām ienem ārkārtīgi svarīgu lomu (apšaubot nabadzỉbas individualizācijas teoriju). Sievietēm, kuras bērnībā bija dzivojušas funkcionālās ǵimenēs, kuru talanti tikuši attīstìti dažādās ārpusskolas aktivitātēs, ir arī vairāk iekšējo resursu tikt galā ar grūtībām, labākas dzives prasmes, augstākas prasības pret sevi kā mātēm un to, ko viṇas vēlas dot saviem bērniem. Sievietēm, kuras pieredzējušas vecāku nolaidỉgu attieksmi vai pat aprūpētāju vardarbỉbu, ir daudz grūtāk pārvarēt citus kritiskus dzives notikumus, veidot funkcionālas partnerattiecỉbas. Kaut arī stāstījumi skaidri parāda kritiskā notikuma lomu, tāāāk sekojošo negatīvo notikumu un grūtību akumulāciju, tie parāda arī sievietes kā radošas būtnes, kuras maksimāli izmanto pieejamos ierobežotos resursus un veido normālu dzivi.

Satraucošāks ir jautājums par morālo pašcieṇu un cerībām dzīvot cieṇpilnu dzivi. Stāstos mijas cerības un bezcerība, uzṇēmība un nomāktỉba, cīna par ikdienas izdzīvošanu un sapni par labāku nākotni. Ja ne sev, tad bērniem. Sievietes visvairāk pārdzīvo par savu nespēju (reālu vai iespējamu) dot bērniem visu nepieciešamo, lai bērnu dzive būtu normāla tagad un labāka nākotnē. Valsts atbalsts tiek interpretēts kā nepietiekošs un uz izdzìvošanu, nevis attīstību vērsts. Iespējas ievērojami uzlabot ğimenes finansiālo stāvokli pašu spēkiem ir vērtējamas kā niecīgas. Sieviešu nodarbinātỉbas iespējas ir ierobežotas gan viṇu zemās izglìīibas dēl, gan viṇu dzīvesvietu ierobežoto iespēju dēl-pašlaik vinas var strādāt tikai maz atalgotus, vienkāršus darbus, turklāt mazo bērnu mammām ir jāspēj līdzsvarot darba un bērnu aprūpes pienākumus. Stāsti tieši un netieši atsedz mazo jēgu strādāt maz atalgotu darbu (pieaugoša slodze, lai atalgotu darbu savienotu ar darbu piemājas saimniecībā, kas nodrošina dạı pārtikas; pieaugošas transporta un bērnu pieskatišanas izmaksas, kuru dēḷ strādāt zemu atalgotu darbu faktiski neatmaksājas). Iespējas pabeigt pamatskolu vai vidusskolu, kā arì iegūt profesionālu kvalifikāciju visām sievietēm ir ierobežotas dažādu iemeslu dēḷ. Tikai galvaspilsētā un lielākajās pilsētās ir pietiekami plašas pamata, vidējās izglìtỉbas un tālākizglìtības iespējas. Lauku apvidos šādu iespēju nav, savukārt ar zglìtỉbas un kvalifikācijas iegūšanu saistîtās izmaksas un nepieciešamība uz izglìitibas iegūšanas laiku pilnībā vai daḷēji deleg̛ēêt kādam citam bērnu aprūpi un to vēl savienot ar darbu padara izglitības un profesijas iegūšanu par gandrīz neiespējamu. Toties tālmācỉbas iespējas prasa labas datorprasmes un pietiekošu piekḷuvi datoram ar interneta pieslēgumu, un ne visām sievietēm šādi resursi ir. Partnerattiecībās esošajām sievietēm vēl jāsadzīvo ar dzivesbiedra alkohola atkarību, kas ikdienai pievieno dažus riska faktorus. Partnera esamība gan rada pilnas ğimenes ilūziju, tomēr savas atkarỉbas dēl vini katrā brīdi var klūt par vēl vienu problēmu. Izveidojas noslēgts apburtais logs - nav kvalifikācijas, nav cerību uz pietiekoši atalgotu darbu; ja nav naudas un atbalsta bērnu aprūpē, kvalifikāciju iegūt ir neiespējami. Grūtību plašais spektrs šis sievietes padara seviški ievainojamas.

Individuālo situāciju padzilināta analīze liecina: lai sanemtu sociālo palīdzìbu un pakalpojumus, izškikiroša loma ir iejūtīgam un uzmanīgam sociālajam darbiniekam, kurš iedziḷinās individuālajos gadỉjumos un palīdz meklēt risinājumus (kas ir seviški svarīgi situācijās, kad formālie kritēriji liedz saṇemt palīdzỉbu, bet pēc būtības tā ir ḷoti nepieciešama). Tāpat analìze rosina domāt par sociālās palīdzības un pakalpojumu saṇemšanai izvirzìtajiem kritērijiem un to elastības trūkumu. Noteikti ir jādomā par elastīgāku pieeju viena vecāka un daudzbērnu ǵimeṇu gadijumā, kā arī par kritēriju vienādošanu maznodrošinātā statusa iegūšanai. Nav pieḷaujama situācija, kad cilvēki ar līdzīgām problēmām un vajadzībām, sevišḳi bērni, nevar saṇemt palīdzibu un pakalpojumus uz vienādu nosacijumu pamata. Tāpat izgaismojas atsevišķu loti būtisku pakalpojumu neesamība (piemēram, valsts finansētas psihologa konsultācijas depresijas, lïdzatkarības, smagu traumatisku notikumu pārvarēšanai) un esošo pakalpojumu nepieejamība (formāli pakalpojums ir, bet reāli pašvaldības ierobežotās rocības dēḷ nav pieejams). Tāpat sociālās politikas veidotāji ir sevišḳi sarežğìita uzdevuma priekšā, lai izstrādātu tādus atbalsta mehānismus, kas būtu atbilstoši konkrētās mērkgrupas vajadzībām un spētu efektīvi palīdzēt jauno sieviešu komplekso problēmu risināšanā ilgtermiṇā (galvenokārt atbalstot bērnu aprūpi reizē ar izglìtības un profesionālas kvalifikācijas iegūšanu, kas lautu sievietēm atrast darbu par atalgojumu virs minimālā un pārraut nabadzības strupcelu). Te jādomā par sociālā budžeta palielināšanas iespējām, kas ḷautu nodrošināt plašāku pakalpojumu klāstu un uzlabotu jau esošo pakalpojumu pieejamỉbu - sevišḳi attiecỉbā uz pakalpojumiem, kuri stiprina cilvēka pašapzinu un rīcībspēju. Jārisina arì jautājums par pietiekošu atbalstu bērnu izglìtībai un talantu attīstībai, lai viniiem nebūtu jāatkārto savu vecāku dzīves modelis. Tomēr atšḳirīibā no pieaugušajām sievietēm, kurām precizi mērkèta palìdzība un pakalpojumi var efektīvi palīdzēt situāciju risināšanā, mērkēta palīdzība bērniem var pastiprināt viṇu stigmatizāciju. Bērnus nevajadzētu saistìt ar vecāku uzvedību un problēmām. Attiecībā uz bērniem noderīgāki būtu universāli atbalsta mehānismi, kas bērnam nepiekar birkas jau mazā vecumā un neliek justies negatīvā nozīmē citādiem kā pārējie.

Tomēr pastāv arī iespējas, kas ir ārpus valsts sociālās palīdzības un pakalpojumu ietvara un ārpus sieviešu individuālajiem resursiem,-iespējas, kas sakṇojas privātajā un nevalstiskajā sektorā. Kā loti efektivss instrument analīzē parādijāas reliğisko organizāciju sniegtā palīdzība, kuras pamatā i vajadzỉbu un līdzjūtỉbas princips, nevis cilvēka materiālās situācijas formāls novērtējums. Sanemtā palīdzība ir ne tikai tūlītēja (nav jāgaida vairākas 
nedēlas, kamēr izskata iesniegumu (vai pat mēneši un gadi, 3 Sk. http://old.brigade.lv/ kā tas ir nesakārtotu juridisko formalitāšu gadijjumos)), bet atbalstitie/mammu arī pašcieņu neaizskaroša un, varētu pat teikt, dvēseli dziedinoša (cilvēkam krīzes situācijā ir būtiski, ka vinu nekritizē un

nevērtē moralizējoši, bet lïdzcilvēki vinu pienem un atbalsta tādu, kāds vinšs ir). Starp citu, universālā pamatienākuma idejas aizstāvji ir pārliecināti, ka beznosacījumu pamatienākums spēs efektīvāk mazināt pastāvošo nabadzību un nevienlïdzību (Thornhill \& Atkins, 2016), arī beznosacijumu atbalsts darbojas kā daudz efektīvāks pašcieṇu un rīcībspēju stiprinošs instruments nekā uz lỉdzekḷu izvērtēšanu balstīts atbalsts (Lacey, 2017). Iespējams, ka ir jāpielauj iespēja vienu reizi dzivē sanemt beznosacijumu sociālo palïdzìbu krìzes situācijāa arī pašvaldības sociālajā dienestā. Kā līdz šim seviški maz izmantots resurss, kas arī neparādās nevienā no pētijumā aplūkotajām individuālajām situācijām, jāmin sociālās uznēmējdarbības attīstiššna, kas varētu nodrošināt precīzi mērkētas apmācỉbas un darba iespējas šādām sievietēm, kuras vienas audzina bērnus vai kurām ir iespēja strādāt tikai no mājām. Labās prakses piemērs Latvijā ir sociālais modes zìmols «MAMMU» ${ }^{3}$, ko attīsta Laikmetīgās mākslas centrs, radot darbvietas māmiṇām, kurām jāapvieno iztikas pelnīšana ar bērna audzināšanu. Mērḳtiecīgs atbalsts sociālajai uzṇēmējdarbỉbai un plašāks tādu alternatīvo sociālo pakalpojumu klāsts, kuri vērsti uz noteiktu grupu apmācību un ieklaušanu darba tirgū, varētu loti veiksmīgi un efektivi palīdzēt problēmas risināšanā.

\section{Izmantotie avoti}

Almqist, Y. (2016). Childhood origins and adult destinations: The impact of childhood living conditions on coexisting disadvantages in adulthood. International Journal of Social Welfare, 25(2), pp. 176-186. doi:10.1111/ijsw.12178

Ansari, S., Munir, K., \& Gregg, T. (2012). Impact at the 'Bottom of the Pyramid' The Role of Social Capital in Capability Development and Community Empowerment. Journal of Management Studies, 49(4), pp. 813-842. doi:10.1111/j.1467-6486.2012.01042.x

Bak, C. K., \& Larsen, J.L. (2015). Social exclusion or poverty individualisation? An empirical test of two recent and competing poverty theories. Europea Journal of Social Work, 18(1), pp.17-35. doi:10.1080/13691457.2013.878316

Bela, B. (2017). Tricky circle of adversity: problems of social support for vulnerable groups in rural areas. Proceedings of the 2016 International Conference «Economic science for rural development», 46, pp. 23-30.

Bezdarba un sociālās atstumtības iemesli un ilğums (2007). Pētỉjuma ziṇojums, pētnieku grupas vadìtāja Ritma Rungule. Latvijas Universitātes ağentūra «LU Filozofijas un socioloğijas institūts», biedrỉba «Baltic International
Centre for Economic Policy Studies», SIA «Socioloğisko pētijumu institūts». Rỉga: Latvijas Universitātes aǵentūra «LU Filozofijas un socioloğijas institūts». Centrālā statistikas pārvalde (2016). Ienākumi un dzives apstākḷi Latvijā 2015. gadā. Statistisko datu krājums. Rigga: Centrālā statistikas pārvalde.

Centrālā statistikas pārvalde (2017). Nabadzības riskam Latvijā paklauti 424 tūkstoši jeb 21,8\% iedzivotāju. 2017. gada 2. februāris. Izgūts no http:// www.csb.gov.lv/notikumi/nabadzibas-riskam-latvija-paklauti-424-tukstosijeb-218-iedzivotaju-45823.html

Copeland, P., \& Daly, M. (2012). Varieties of poverty reduction: Inserting the poverty and social exclusion target into Europe 2020. Journal of European Socia Policy, 22(3), pp. 273-287. doi:10.1177/0958928712440203

Dobelniece, S., Millere, J., \& Salmane-Kulikovska, I. (2015). Situation analysis of social risk families with children in Latvia. Economic Science For Rural Development. Marketing and Sustainable Consumption. New Dimensions in the Development of Society, 40, pp. 141-15o.

Dudwick, N., Trapenciere, I., Rungule, R., Pranka, M., \& Lāce, T. (1998). Nabadzīgo cilvēku viedokli : nabadzïbas sociālais vērtējums Latvijā. Atskaite par pētijumu. Rỉga: Filozofijas un socioloğijas institūts. Izgūts no http://petijumi. mk.gov.lv/

Eiropas Komisija (2010). Eiropa 2020 Stratêgijija gudrai, ilgtspējigai un integrējoša izauğsmei. Brisele. Publicēts 10.10.2010. Izgūts no http://ec.europa.eu/ eu2020/pdf/1_LV_ACT_part1_v1.pdf

Eurofound (2012). Third European Quality of Life Survey - Quality of life in Europe: Impacts of the crisis, Luxembourg: Publications Office of the European Union. Retrieved from www.eurofound.europa.eu/pubdocs/2012/64/en/1/ EF1264EN.pdf

Eurostat (2016). Material deprivation and low work intensity statistics. Retrieved from http://ec.europa.eu/eurostat/statistics-explained/index.php/Material deprivation_and_low_work_intensity_statistics\#At_risk_of_poverty_or_ social_exclusion

Fahmy, E., \& Pemberton, S. (2012). A Video Testimony on Rural Poverty and Socia Exclusion. Sociological Research Online, 17(1)2. Retrieved from http://www. socresonline.org.uk/17/1/2.htm

Gātere, D. (2017). Alternatìvās vīrietības prakses (mağistra darbs). Rīga: Latvijas Universitātes Sociālo zinātnu fakultātes Socioloớijas nodala.

GfK Custom Research Baltics (2013). Sākotnējs izvērtējums «Trūcīgo mājsaimniecìb ar bērniem raksturojums». Izgūts no http://www.lm.gov.lv/upload/ petijumi/ izvertejums_trucigas.pdf

Hick, R. (2014). Poverty as Capability Deprivation: Conceptualising and Measuring Poverty in Contemporary Europe. European Journal of Sociology/Archives Européennes de Sociologie, 55(3), pp. 295-323. https://doi.org/10.1017/ Sooo3975614000150 
Jackson, S., \& Cameron, C. (2012) Leaving Care: Looking ahead and aiming higher. Children and youth services review, 34(6), pp.1107-1114.

Labklājības ministrija (2017). Informācija par Sociālo pakalpojumu un sociālās palīdzìbas likuma piemērošanu sociālā darba un sociālās palīdzības jomāa atbilstoši 2017. gada 12. janvāra grozījumiem likumā. Stājās spēkā 2017.gada 9. februārī. Izgūts no http://www.lm.gov.lv/upload/aktuali/informacijai_ spsplgroz_2017f.pdf

Labklājīibas ministrijas Sociālās iekḷaušanas un sociālā darba politikas departaments (2016). Valsts statistikas pārskatu kopsavilkums. Pārskati par sociālajiem pakalpojumiem un sociālo palìdzìbu novada/republikas pilsētas pašvaldībā 2015. gadā. Izgūts 02.01.2017. no http://www.lm.gov.lv/text/3400

Lāce, T. (2012). Sociālā atstumtība Latvijāa. Rīga: Zinātne.

Lacey, A. (2017). Universal basic income as development solution? Global Social Policy, 17(1), pp.93-97. doi:10.1177/1468018116684269

lsm.lv ziṇu redakcija (2017). Straujš atalgojuma kāpums vērojams visā Baltijā lielākās algas joprojām ir Igaunijā. Riga: Latvijas sabiedriskie mediji. 30.08.2017. Izgūts no http://www.lsm.lv/raksts/zinas/ekonomika/straujsatalgojuma-kapums-verojams-visa-baltija-lielakas-algas-joprojam-irigaunija.a248435/

Marttila, A., Johansson, E., Whitehead, M., \& Burström, B. (2013). Keep going in adversity - using a resilience perspective to understand the narratives of long-term social assistance recipients in Sweden. International Journal for Equity in Health, 12:8, pp.1-11. Retrieved from http://www.equityhealthj. com/content $/ 12 / 1 / 8$

Mood, C. (2015). The not-very-rich and the very poor: Poverty persistence and poverty concentration in Sweden. Journal of European Social Policy, 25:3, pp. 316-330.

Peruzzi, A. (2015). From Childhood Deprivation to Adult Social Exclusion: Evidence from the 1970 British Cohort Study. Social Indicators Research, 120:1, pp. 117-135.

Rasnača, L., \& Niklass, M. (2013). Sociālā ilgtspēja: vai nevienlīdzīgas sabiedrības ir ilgtspējigas? No B. Bela (red.), Latvija. Pārskats par tautas attīstību 2012/2013. Ilgstspējiğa nācija (13.-33.lpp.). Rỉga: LU Sociālo un politisko pētijumu institūts.

Rizga, K. (2012). Latvijas «veiksmes stāsta» slēptā puse. Slēptā nabadzība Latvijāa.

dzìve ar «Dieva žêlastību un cilvēku labestību». Rỉga: Re:Baltica. Izgūts no https://rebaltica.lv/2012/10/slepta-nabadziba-latvija-dzive-ar-dievazelastibu-un-cilveku-labestibu/

Saeima (2010). Latvijas ilgtspējiğas attīstības stratếgija lìdz 2030. gadam. Apstiprināts ar 2010.gada 10. jūnija Latvijas Republikas Saeimas lēmumu. Izgūts no http://www.latvija203o.lv/upload/latvija2030_saeima.pdfLR Saeima Stiglitz, E.J. (2015). The Origins of Inequality, and Policies to Contain It. Nationa Tax Journal, 68(2), pp.425-448. doi:dx.doi.org/10.17310/ntt.2015.2.09 Retrieved from http://www.ntanet.org/NTJ/68/2/ntj-v68no2p425-448-originsinequality-policies-contain.html

Thornhill, J., \& Atkins, R. (2016). Universal basic income: Money for nothing. Finacial Times, May 26, 2016. Retrieved from https://www.ft.com/ content/7c7ba87e-229f-11e6-9d4d-c11776a5124d

Walker, J., Crawford, K., \& Taylor, F. (2008). Listening to children: gaining a perspective of the experiences of poverty and social exclusion from children and young people of single-parent families. Health and Social Care in the Community, 16(4), pp.429-436. doi:10.1111/j.1365-2524.2008.00781.X

Walker, R. (2014). The Shame of Poverty. Oxford: Oxford University Press.

Whelan, C.T., \& Maître, B. (2005a). Vulnerability and multiple deprivation perspectives on economic exclusion in Europe: A latent class analysis. European Societies, 7(3), pp.423-45o. doi:10.1080/14616690500194050

Whelan, C. T., \& Maître, B. (2005b). Economic Vulnerability, Multidimensiona Deprivation and Social Cohesion in an Enlarged European Community. International Journal of Comparative Sociology, 46(3), pp. 215-239. doi:10.1177/0020715205058942

The World Bank (2013). Latvia: Who is Unemployed, Inactive or Needy? An Assessmen of Post-Crisis Policy Options. Retrieved from http://www.lm.gov.lv/text/2562 


\title{
Sociālās inovācijas
}

\author{
labākai dzīvei
}

3 


\section{Sociālās inovācijas: valsts loma to \\ sekmēšanā pasaulē un Latvijā}


Bourgon) akcentē, ka biznesa motivācija inovācijās ir peḷna, bet sabiedrības motivācija sociālajās inovācijās ir sociālie labumi, kurus tā rezultātā gūst (Bourgon, 2011). Šajā apstāklī ir saredzams būtiskākais pamatojums valstij iejaukties un motivēt sociālo inovāciju norisi, ja vien pastāv nosacijums, ka sociālās inovācijas sasniedz rezultātu, proti, sociālās problēmas tiek risinātas efektīvāk nekā līdz tam. Kā rīcībpolitikas pamatojums sociālo inovāciju kontekstā literatūrā tiek minēti lielie sociālie izaicinājumi, piemēram, sabiedrības novecošanās, klimata pārmainas un citi. Tā kā šiem izaicinājumiem nepieciešami vispusīgi risinājumi un būtiska sabiedrïbas iesaiste, tad pastāv pamatojums īstenot rīcībpolitiku, kas vērsta uz sociālām inovācijām (Benneworth et al., 2014).

OECD (Organization for Economic Development and Cooperation) sociālās inovācijas definē šādi: «Sociālās inovācijas ietver konceptuālas, procesa vai produkta pārmainas, organizacionālas pārmainas un pārmainas finansēšanā, un tās var būt saistìtas ar jaunām attiecībām ar iesaistìtajām pusēm un teritorijām. Sociālās inovācijas meklē atbildes uz sociālām problēmām, identificējot un piedāvājot jaunus pakalpojumus, kas uzlabo individu un sabiedrības dzives kvalitāti.» (OECD, 2010, p. 196). Šajā definīcijā būtisks ir akcents uz to, ka sociālās inovācijas ietver arī konceptuālas pārmaiṇas, kas ir plašākas nekā tikai jauni pakalpojumi vai produkti. Līdz ar to sociālās inovācijas tiek apskatîtas ne vien kā produkti vai pakalpojumi, bet arī kā process (Wehn \& Evers, 2015).

Cita sociālo inovāciju definīcija nosauc piecas iezīmes, kuras nepieciešamas, lai varētu runāt par sociālo inovāciju. Pirmkārt, sociālajai inovācijai ir jāparedz kaut kas jauns. Otrkārt, tai ir jārisina sabiedrībai aktuāla problēma vai vajadzība. Šì saraksta autori norāda, ka sociālā inovācija var būt ne vien problēmas risinājums, bet tās aktualizācija, kas sakrīt ar iepriekš minēto, ka sociālā inovācija var būt arī process. Treškārt, tai ir jābūt istenotai praksē, pretējā gadījumā to precīzāk būtu dēvēt par sociālo izgudrojumu, kas ir tikai ideja, kura nav īstenota praksē. Ceturtkārt, tai ir jāiesaista mērḳgrupas, kuras tā skar, lai nodrošinātu tās leg̣itimizāciju. Visbeidzot, tai jāspēj mainìt sociālo uzvedību un jārada pārmainas (Ross \& Godard, 2015).

Sociālajām inovācijām tiek nošḳirtas trīs dimensijas. Pirmā ietver cilvēku neapmierināto vajadzību apmierināšanu. Otrā attiecināma uz procesiem un pārmainām un līdzdalības palielināšanu, īpaši līdz tam izslēgtām grupām. Trešā dimensija paredz, ka sociālās inovācijas var palielināt iesaistìto iespējas, uzlabojot prasmes un pieeju resursiem (Mouleart et al., 2005).

Lielā mērā sociālās inovācijas definīciju nosaka zinātnes nozare, kas to aplūko. No tās atkarīgs arī pētỉjumu fokuss. Piemēram, socioloğijā sociālo inovāciju jēdziens ir interesants, jo sociālā inovācija tiek apskatīta kā sociālu pārmaiṇu avots. Citā kontekstā sociālās inovācijas tiek analizētas kā radošuma avots - tiek analizēts, kādi faktori ietekmē jaunu radošu ideju rašanos
(Majumdar et al., 2015). Organizāciju studijās sociāāā inovācijas tiek apskatìtas kā iespēja organizācijām labāk piemēroties mainīgiem ārējiem apstākliem (Grimm et al., 2013). Vides zinātnēs sociālo inovāciju jēdziens izmantots, lai akcentētu globālo, plašo un sociālo raksturu problēmām, kas saistìtas ar vides jautājumiem, kuru risināšanai sociālās inovācijas ir viena no cerībām. Vides zinātnieki norāda, ka nepietiks vien ar tehnoloğiskām inovācijām, lai risinātu vides problēmas (Grimm et al., 2013).

Sociālās inovācijas ir interesantas arī no biznesa menedžmenta studiju viedokḷa, koncentrējoties uz sociālo uzṇēmējdarbību un analizējot Jozefa Šumpētera (Joseph Schumpeter) idejas. Psiholog̣ijā sociālās inovācijas ir piesaistījušas pētnieku uzmanību, jo tām kā kolektīvai rīcībai ir kolektīva ietekme, kas ir interesanta no kopienu psiholoğijas perspektīvas. Ir pētījumi, kas pievēršas sociālām inovācijām no teritoriālās attīstības perspektīvas, akcentējot to nozīmību tādu sociālu problēmu risināšanai, kas ir aktuālas specifiskās teritorijās. Visbeidzot, tiek izškirti arī pētijumi un zinojumi, kas ir balstīti uz praksi, nevis uz teoriju. Šì literatūra galvenokārt koncentrēta uz dažādu praktisku padomu sniegšanu sociālo inovāciju stratêǵiju attîstībai, atsevišku gadijjumu un piemēru aprakstu un rekomendācijām politikas veidotājiem (Majumdar et al., 2015). Kā redzams, sociālās inovācijas ir interesantas dažādām sociālo zinātṇu apakšnozarēm, kas tās pēta no samērā dažādām perspektivām, ar ko var izskaidrot plašo jēdziena definiciju klāstu un to atškiirības. Neizbēgami sociālo inovāciju izpēte ir starpdisciplinārs pētijumu virziens.

Literatūrā, kas apskata dažādus faktorus, kuri ietekmē sociālās inovācijas, cita starpā minēta arī vieta jeb teritorija kā faktors, kas var ietekmēt to, cik liela ir iespējamība, ka tajā notiks sociālo inovāciju procesi. Proti, norādìts, ka pilsētās un plašāk apdzìvotās vietās ir lielāka iespējamība sociālo inovāciju procesiem, jo šādās vietās ir lielāka dažādu tehnoloğiju pieejamība, cilvēkresursi, finansējums un citi resursi (Abad, 2014). Tā kā pastāv dažādas specifiskas problēmas, ar kurām var saskarties lauku teritorijas, politika veidotājiem būtu jānnem vērā, ka sociālām inovācijām var būt ierobežota izplatība un ietekme. Arī tādu problēmu risinājumi, kuras ir aktuālas neatkarīgi no teritorijas, var ietekmēt ne tikai urbānās teritorijas.

Runājot par sociālām inovācijām un valsts lomu, jānorāda, ka sociālas inovācijas notiek reti. To īstenošanai var trūkt materiālas motivācijas, un cilvēkiem, kas varētu tās īstenot, var nebūt finansiālo, laika un citu resursu savu ideju realizācijai. Līdz ar to ir piẹ̦aujams, ka valsts ar tās ìstenoto politiku iejaucas, risinot pastāvošo tirgus klūdu un motivējot cilvēkus tomēr istenot sociālas inovācijas, jo tās ir sabiedriski vēlamas (Pol \& Ville, 2009). Tajā pašā laikā ir jāṇem vērā, ka jebkuriem valsts instrumentiem, lai risinātu tā saucamo tirgus klūdu (nepietiekams sociālo inovāciju apjoms un nepietiekami stimuli radīt sociālās inovācijas), ir jābūt pārdomātiem. Ir rūpigi jāizvērtē, 
kas ir sociālo inovāciju procesus kavējošie faktori, kā tos efektivvāk novērst, kādi ir nepieciešamie resursi un sagaidāmie rezultāti.

Par valsti un sociālām inovācijām var runāt divos kontekstos. Vienā no tiem, kas ir centrālais arī šajā rakstā, var redzēt valsts kā sociālo inovāciju atbalstītājas lomu. Taču pastāv arī skatijums, ka valsts pati var istenot sociālās inovācijas. Piemēram, pārmaiṇas, kas skāra publisko pārvaldi un tās darbības organizēěanu pēc Otrā pasaules kara un tiek saistìtas ar jaunās publiskās pārvaldes jēdzienu, arī varētu dēvēt par sociālām inovācijām, kaut gan tas nav praktizēts (Levesque, 2013). Lìdzīgi valsts var radìt inovācijas, piedāvājot sociālos pakalpojumus, un citos veidos. Taču, kā atzīst pētnieki, parasti jauni un efektīvi rīcibpolitikas risinājumi tiek dēvēti par labu rīcỉbpolitiku, nevis par sociālo inovāciju (Minks, 2011).

Lai labāk izprastu valsts lomu sociālo inovāciju sekmēšanā, ir jāapskata plašāki apstākḷi, kas nosaka to norisi. Diemžēl salīdzinoši nesenā un fragmentārā sociālo inovāciju izpēte nesniedz viennozimīgas atbildes uz šo jautājumu. Lìdz ar to rekomendācijas politikas veidošanai nav viegli izstrādājamas. Sociālo zinātṇu pètỉjumus par sociālo inovāciju procesiem var iedalìt divās grupās. Viena no šīm grupām ir ağentu pieeja, kas pienem, ka sociālās inovācijas ir indivìdu un to personīgās motivācijas virzìtas. Lìdz ar to šajā pieejā izpēte koncentrējas uz individuālo aǵentu motivāciju. Otra izmantotā pieeja ir strukturālā, kas paredz, ka sociālās inovācijas ietekmē strukturālais konteksts, tajā skaitā valsts radītā vide un stimuli (Caijaba-Santana, 2014). Pilnvērtīgai izpratnei par sociālo inovāciju procesiem būtu jākombinē abas pieejas, pētot gan individuālas motivācijas, gan ārējos faktorus, kas ietekmē sociālās inovācijas.

No līdzšinējās izpētes ir secināms, ka sociālo inovāciju stimuli ir kompleksi un nevar runāt par kādiem atsevišşiem faktoriem (Franz, Hochgerner, \& Howaldt, 2012). Tas nozīmē, ka arī politikas veidotāju atbilde nevar būt vienveidīga. Jāṇem vērā arī tas, ka sociālās inovācijas ir atkarīgas no konteksta (Osburg \& Schmitdpeter, 2013), tāpēc tām nevar visās valstīs vai reğiionos piemērot vienādotus risinājumus, lai gan tas nereti ir politikas veidotāju kārdinājums.

Lìdzīgi kā citās sabiedrības dzīves sfērās, arī sociālo inovāciju norisē būtisku lomu ienem internets, sociālie tīkli un iespējas, kādas tie paredz cilvēkiem. Internets ir būtisks sociālo inovāciju norises stimuls. Lai raksturotu inovācijas, kuras ir balstītas uz informācijas un komunikāciju tehnoloğijām vai ir attīstìtas, pateicoties tām, tiek lietots jēdziens «digitālās sociālās inovācijas». Jēdziena definīcija ir šāda: «Digitālās sociālās inovācijas ir sadarbībā istenotas inovācijas veids, kas paredz, ka inovatori, inovāciju lietotāji un sabiedrība sadarbojas, izmantojot digitālās tehnolog̣ijas, lai radītu zināšanas un risinājumus plašam sabiedrisku vajadzỉbu lokam tādā mērā, kādā tas nebija iespējams pirms interneta izmantošanas pieauguma.» (Digital Social
Innovation, 2014) Eiropas Komisijas pasūtītā pētỉjumā par digitālām sociālajām inovācijām tika apzināts vairāk nekā 6ooo dažādu digitālo sociālo inovāciju projektu. Tematiski lielākā daḷa no tiem koncentrējās uz izglìtības un prasmju attīstī̌anas jautājumiem, nākamā lielākā tematiskā kategorija ir jauni līdzdalības modeli, bet salīdzinoši mazāk tika identificēti zinātnes un tehnoloğiju projekti un finanšu risinājumi (European Commission, 2015).

Minētajā pētỉjumā izstrādātas arì vairākas rekomendācijas politikas veidotājiem. Piemēram, norādīts uz nepieciešamību atvieglot piekluvi finansējumam digitālo sociālo inovāciju projektiem, kas var risināt sabiedrības problēmas, izmantot publisko iepirkumu digitālo sociālo inovāciju pakalpojumu izmantošanai. Interesanti, ka zinojumā norādīts - digitālo sociālo inovāciju tỉklos nepieciešams vairāk iesaistìt Austrumeiropas inovatorus un arī politikas veidotājus (European Commission, 2015).

Arī sociālie mediji var būt būtiski sociālo inovāciju îstenošanas un iedzivināšsanas avoti, jo spēj uzrunāt plašas cilvēku masas, kā arī jaunākas paaudzes cilvēkus (Passani et al., 2015). Protams, tam ir arī ierobežojumi, jo ne visām sabiedrības grupām ir pieejami digitālie mediji un piemìt prasmes tos izmantot. Kā piemēri digitālām sociālām inovācijām tiek minēti interneta enciklopēdija Wikipedia, change.org, kas ir platforma sabiedrisku kampanu organizēšanai, Kickstarter, kas ir platforma pūḷa finansējuma savākšanai, un citi (Passani et al., 2015).

Nemot vērā minētos apsvērumus, ir pētnieki, kas lieto arī tādu jēdzienu kā «sociālo inovāciju rīcibpolitika» (Bourgon, 2011; Berzin, Pitt-Catsouphes, \& Peterson, 2014). Taču galvenokārt visas sociālo inovāciju atbalsta iniciatīvas no valsts puses ir salïdzinoši nelielas un drīzāk uzskatāmas par daḷu no kādas citas rīcībpolitikas jomas. Piemēram, ASV, kur federālā lìmenī sociālās inovācijas ir aktuāls rīcībpolitikas jautājums, štatu loma ir neskaidra. Pētijumi par to darbỉbām ir nepietiekami (Berzin et al., 2014), taču, nemo vērā sociālo inovāciju specifiku, tieši štatiem, kas ir tuvāk sabiedrībai, varētu būt lielāka ietekme nekā federālām iniciatīvām. Iespējams, precīzāk būtu runāt par sociālo inovāciju stimulēšanu citu jomu rìcībpolitikās, nevis izcelt tās kā atsevišku rīcībpolitiku.

Ieskats tajā, kādus instrumentus valstis praktiski izmanto, sniegts nākamajā apakšnodalā. Savukārt tabulā ir raksturota iespējamā valsts loma dažādos sociālās inovācijas attīstības posmos. Katrā posmā sociālo inovatoru vajadzības ir atšķirīgas, tāpēc arī rīcībpolitikas atbildes ir jāpiemēro konkrētam posmam. Tā, piemēram, pirms sociālā inovācija vēl ir radusies vai kad tã ir ḷoti agrinā fāzê, valsts loma var būt motivēt domāt par jauniem un efektīiviem risinājumiem sociālu problēmu risināšanā. Tas ir būtiski, ṇemot vērā iepriekš minēto par materiālo stimulu trūkumu, kas atškirir sociālās inovācijas no uzṇēmējdarbības inovācijām, kur tās, lai arī ir riskantas, tomēr var nest būtisku pelnu. 
Tabula. Valsts loma dažādās sociālās inovācijas attīstības pakāpēs

\begin{tabular}{lll}
\hline Sociālās inovācijas attistības pakāpe & Valsts loma \\
\hline 1. & Ideju radīšana & Motivēšana, ekosistēma \\
\hline 2. & Testēšana & Starta finansējums \\
\hline 3. & Paplašināšana un uzturēšana & $\begin{array}{l}\text { Finansējums paplašināšanai, } \\
\text { publiskais iepirkums }\end{array}$ \\
\hline
\end{tabular}

(Mulgan, Tucker, Ali, \& Sanders, 2007)

Brīdī, kad sociālās inovācijas idejas ir radītas un noformulētas, bieži pastāv nepieciešamība tās testēt reālos apstākḷos, lai noskaidrotu to dzivotspēju. Arī šajā attīstības posmā valstij var būt nozìmīga loma, kas galvenokārt var izpausties starta finansējuma formā. Visbeidzot, ja ir izrādijies, ka ideja ir dzìvotspējigiga, tā spēj parādìt pozitīvu ietekmi uz sociālo problēmu, ir nepieciešams to uzturēt un paplašināt, lai tās pozitīvo ietekmi izjustu plašākās teritorijās vai mērkłgrupās. Šajā attīstības pakāpē valsts var palīdzēt ar finansējumu, lai nodrošinātu sociālās inovācijas paplašināšanu, kā arī var pasūtīt konkrēto sociālo inovāciju, izsludinot valsts iepirkumu un tādējādi nodrošinot tai pieprasījumu.

Valsts nav vienīgā ieinteresētā puse, kam var būt pozitīva ietekme uz sociālo inovāciju norisi. Būtiska loma var būt arī uzṇēmējdarbības sektoram, izmantojot savus ietekmes resursus, kas galvenokārt ir finansiāli. Šĩ ietekme var izpausties tiešā veidā, ieguldot privātos resursus konkrētos sociālo inovāciju projektos vai atbalsta iniciatīvās. Taču literatūrā ir apskatīit arī piemēri, kad uzṇēmēju ietekme ir izpaudusies netiešāk. Viens no piemēriem ir ASV kompānijas Levi Strauss rūpnīcas atvēršana Virdžīnijas štatā 2o.gadsimta 6o. gadu sākumā. Štata aktīvisti uzstāja, ka rūpnīcu var atvērt tikai tad, ja tajā strādās vienīgi baltādainie ASV pilsoṇi, bet kompānija tam nepiekrita un solija rūpnicu atvērt citur. Nemot vērā darbvietu nepieciešamïbu, štata pārstāvji piekāpās, un ASV dienvidos tika izveidota pirmā rūpnīca, kurā līdzās strādāja afroamerikāṇi un baltādainie ASV pilsoṇi, radot jaunu sociālo praksi (Saul, 2011). Šis piemērs ilustrē, ka lielām kompānijām un to sabiedriskajai nostājai var būt ietekme uz lokāliem sociāliem procesiem.

Sociālo inovāciju jēdziens ticis arī kritizēts. Viens no kritikas aspektiem ir cieši saistits ar valsts lomu šajos procesos. Proti, pastāv risks, ka var notikt pārāk liela palaušanās uz sociālām inovācijām sociālu problēmu risināšanā-neskaidras jaunas pieejas tiek izmantotas, strādājot ar nopietnām

problēmām (Bonifacio, 2014). Zināmā mērā šai kritikai var pievienoties, taču šādi riski ir novēršami. Kā minēts iepriekš, lai valsts iejauktos un istenotu instrumentus sociālo inovāciju atbalstam, ir nepieciešams ne vien tirgus pamatojums, bet arī valsts spēja šo iejaukšanos sekmigii istenot. Tas ietver arī sociālo inovāciju izvērtēšanu un testēšanu mazākos apmēros, pirms tās tiek piemērotas lielos apmēros.

Citi pētnieki norāda uz iespējamām negaidītām un nevēlamām sekām, kuras var radīt sociālās, kā arī citas inovācijas, bet kurām ir pievērsta loti maza pētnieciskā uzmanība (Segercrantz \& Seck, 2013). Gan riskus, gan nevēlamās sekas, kuras var radīt disruptīvas un arī inkrementālas sociālās inovācijas, var novērst vai vismaz mazināt, izmantojot regulējumu (Grimm et al., 2013), protams, ṇemot vērā to, ka regulējums var arī ierobežot inovācijas procesus. Sociālo inovāciju jēdziens tiek dēvēts arī par kvazikonceptu, jo tam ir akadēmisks pamatojums, tomēr tā nozīme var tikt ietekmēta, un tas rada ap to pastāvošo neskaidrību. Šādi kvazikoncepti var paralēli pastāvēt ar dažādām nozīmēm gan akadēmiskajā, gan rīcībpolitikas veidošanas vidē (Benneworth et al., 2014). Konkrēti iespējamie instrumenti sociālo inovāciju atbalstam apskatìti turpinājumā.

lespējamie instrumenti sociālo inovāciju atbalstam to klasifikācija sistēmas nodrošināšanu sociālo inovāciju procesiem, bet var būt arī daudz proaktīvāki. Pētijumā par ASV štatos izmantotajiem atbalsta instrumentiem sociālām inovācijām tika identificēti 29 dažādi rīcibpolitikas instrumenti (Berzin et al., 2014)

Labvēlīgas vides nodrošināšana ir visbiežāk minētais valsts uzdevums sociālo inovāciju atbalstam (Boelman et al., 2014). Ko sevī ietver sociālo inovāciju ekosistēma? Tā sastāv no tādām ieinteresētajām pusēm, kas virza sociālās inovācijas, un no tādām, kas virza pieprasỉjumu pēc sociālām inovācijām, kā arī no starpniekiem, kas galvenokārt sekmē abu minēto sasaist (sk. att.). Valsts lomu vislabāk var saskatìt tieši kā tādu, kas virza pieprasījumu pēc sociālām inovācijām (Hansson et al., 2014). Var apgalvot, ka sociālo inovāciju ekosistēma ietver arī praktiski visus turpmāk aprakstītos instrumentus, kurus valsts var izmantot sociālo inovāciju atbalstam. Pārdomātas un sistēmiskas pieejas sociālo inovāciju atbalstam ir balstìtas uz stratēgijām vai politikas plānošanas dokumentiem, kas veido ietvaru sasniedzamajiem mērḳiem, izmantojamiem instrumentiem, sagaidāmajiem rezultātiem un to izvērtēšanai. Tāpēc veiksmīgāks sociālo inovāciju atbalsts no valsts puses ir atkarīgs no ilgtermina plānošanas. 
Attēls. Sociālo inovāciju ekosistēmas spēlētāju klasifikācija

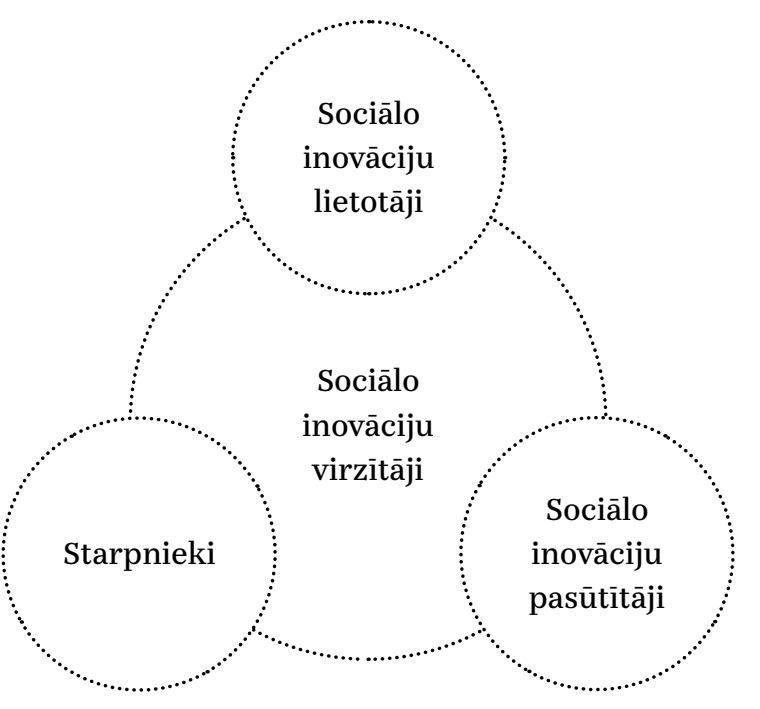

(Hansson, Bjork, Lundborg, \& Olofsson, 2014). Ar autores modifikācijām.

Bez labvēlīgas vides radī̌̌anas sociālās inovācijas var sekmēt ar dažādiem finansiāliem stimuliem, kā, piemēram, konkursu organizēšanu ar naudas balvām vai grantu pieškiršanu. Šādi stimuli var būt nozīmīgi iepriekš apskatītajā sociālo inovāciju ideju radīšanas fāzē, kad, piemēram, konkursi var stimulēt radīt sociālās inovācijas. Tie var būt organizēti bez tematiskām nostādnēm vai var būt koncentrēti uz kādas sociālās problēmas risināšanu, aicinot sabiedrību nākt klajā ar konkrētiem piedāvājumiem. Savukārt grantu finansējums var tikt izmantots testēšanas fāzē, lai pārliecinātos par sociālo inovāciju ideju dzīvotspēju.

Nepieškirot finansējumu tiešā veidā, sociālo inovāciju projektus var atbalstìt arī netieši, piemēram, izveidojot labvēlīgāku nodokḷu likmi vai piemērojot nodokḷu atlaides noteiktām darbībām.

Praksē valstis finansējumu sociālām inovācijām izmanto dažādos apmēros. Lielbritānija, Vācija, ASV minamas kā piemēri, kas ir salīdzinoši aktīvi sociālo inovāciju atbalstīšanā. Piemēram, Lielbritānija, koncentrējoties uz konkrētu nozari, ir investējusi veselības aprūpes inovāciju fondos, kas atbalsta sociālās inovācijas, kuras risina problēmas veselības aprūpē. Tāpat Lielbritānijā finansējums, lai finansētu inovācijas, tajā skaitā sociālās inovācijas, tiek izmantots arī no nacionālās loterijas līdzekḷiem (OECD, 2010). ASV savukārt ir izveidots speciāls birojs, kas strādā ar sociālo inovāciju jautājumiem, kas cita starpā organizē finansējumu inovācijām izglìtỉbas jomā
(Social Innovation Europe initiative, 2011). Par to nepieciešama turpmāka izpēte, bet, iespējams, šo valstu piekoptā prakse finansējumu koncentrēt konkrētās nozarēs, nevis horizontālos sociālo inovāciju pasākumos ir stratēǵiski pareizāka rīcība, ņemot vērā neskaidro valsts instrumentu ietekmi uz sociālo inovāciju iniciatīvām.

Pārnacionālā līmenī, piemēram, Eiropas Komisija un Eiropas Investī ciju fonds izstrādā arī finanšu instrumentus sociālo inovāciju finansēšanai. Eiropas Komisija ir uzdevusi Eiropas Investīciju fondam ieviest garantiju finanšu instrumentu, kas ir veltîts mikrofinansēšanai un sociālās uzṇēmējdarbības finansēšanai. Instrumenta mērḳis ir palielināt mikrofinansējuma pieejamību neaizsargātām sabiedrības grupām, kurām ir loti sarežğìti iegūt aizdevumus tradicionālā veidā, kā arī uzlabot finansējuma pieejamību sociāliem uzṇēmumiem (European Investment Fund, 2016), kas var būt arī sociālo inovāciju autori.

Minētais finanšu instruments darbojas plašākas Eiropas Komisijas programmas «Nodarbinātības un sociālās inovācijas programma» ietvaros, kuras kopējais finansējums pārsniedz 900 miljonus eiro. Bez finanšu instrumenta ši programma sevī apvieno arī 2007.-2013. gadā istenotās programmas «Progress» un «EURES», kas bija vērstas uz nodarbinātības problēmu risināšanu (Eiropas Komisija, 2013). Eiropas Komisija atbalsta arī sociālo inovāciju finansēšanu kohēzijas politikas ietvaros, veidojot struktūrfondu atbalsta programmas. Vai un kā tas izpaužas Latvijas gadijjumā, aplūkots Latvijas situācijas analīzei veltītajā apakšnodạ̣ā.

Eiropas Komisijā sociālo inovāciju jēdziens kluva aktuāls, pārskatot Lisabonas stratēǵijas progresu, kad tapa skaidrs, ka tās progress ir nepietiekams, un domājot par jauno stratēǵiju «Eiropa 2020» (Bonifacio, 2014). Eiropas Savienības kontekstā sociālo inovāciju jēdziens veidojas no ES kontekstā loti sasāpējušām sociālām problēmām, kurām tiek gaidìts risinājums, kā arī no Lisabonas stratēǵijas diskursa, kas koncentrējas uz inovāciju nozīmi un nepieciešamību Eiropas Savienībai uzlabot savu inovācijas sniegumu (Bonifacio, 2014). Vienlaikus pētnieks akcentē to, ka veids, kā Eiropas Komisija ir definējusi sociālās inovācijas, proti, norādot, ka ierobežota budžeta laikā ir nepieciešams sabiedrības un indivīdu radošums, lai risinātu sabiedrības problēmas ar sociālo inovāciju palīdzību, - liecina, ka cilvēkiem ir jārisina problēmas, kuras valstis vairs nevar atlauties risināt (Bonifacio, 2014) No vienas puses, var teikt, ka šĩ ir tikai viena autora skeptiska sociālo inovāciju jēdziena definicijas interpretācija, bet, no otras puses, tomēr zināmā mērā pastāv risks, ka politikas veidotāji var izmantot sociālo inovāciju jēdzienu, la aicinātu sabiedrību nākt klajā ar saviem risinājumiem un tādējādi nemeklēt līdzekḷus sociālo problēmu risināšanai.

Starptautisko organizāciju līmenì lielu uzmanību sociālajām inovācijām pievērsis Pasaules Ekonomikas forums, kas ir izstrādājis vadlīnijas 
valdībām sociālo inovāciju atbalstam un apkopojis dažādu gadijumu analīzes (World Economic Forum, 2013). Ziṇojumā norādīts, ka valstij ir būtiska loma tādu biznesa modeḷu atbalstī̌sanā, kuri paredz sociālus labumus. Tajā piedāvāti seši būtiski valstu rīcības virzieni, proti, atbalsts sociālo inovāciju tỉkliem un galvenajām ieinteresētajām pusēm, valsts spēju attīstǐšana sociālo inovāciju atbalstam, infrastruktūras attīstīšana un sociālo inovāciju starpnieku atbalsts, atbalsts uzṇēmumu izaugsmei, privātā kapitāla papildināšana un rīcībpolitikas izvērtēšana un uzlabošana (World Economic Forum, 2013). Atšḳirỉbā no citiem avotiem, būtiski, ka šajā akcentēta nepieciešamība attīstìt arī pašas valsts spējas un izvērtēt rīcībpolitikas nepieciešamību, jo šì ir jauna joma, kurā tiek sagaidīta valsts iejaukšanās, tāpēc publiskās pārvaldes kapacitātes izvērtēšana ir ḷoti svarīga. Viens no aspektiem, ar ko var sākt šo izvērtēšanu, ir saprast, vai jaunās funkcijas var veikt jau pastāvošās struktūras vai arī nepieciešamas jaunas institūcijas (World Economic Forum, 2013).

Ierobežotu budžeta līdzekḷu kontekstā, kad finansējums ir nepietiekams arī tehnoloğisko inovāciju atbalstam, kas tiek uzskatìts par priekšnosacijumu ekonomikas konkurētspējai, var būt politiski sarežğîti aizstāvēt nepieciešamību investēt sociālo inovāciju atbalsta pasākumos. Gan tehnoloǵisko, gan sociālo inovāciju procesi ir saistīti ar risku, jo tie var arī neizdoties, un tas vēl vairāk var radīt ierobežojumus investīijām sociālajās inovācijās. Pastāv risks, ka finansējums tiek izlietots nepiemēroti, kā arī risks, ka piedāvātās iniciatīvas neizrādās efektīvas. Tie ir faktori, kas politikas veidotājiem ir jāṇem vērā, plānojot finansējumu inovācijām, un tie nedrīkst ierobežot šādas iniciatīvas. Riskus var mazināt, finansējumu pieškirot pakāpeniski un nelielos apjomos, lai pārliecinātos par sociālo inovāciju dzīvotspēju (Social Innovation Europe initiative, 2011). Taču gan tehnoloğiskās, gan sociālās inovācijas ir dārgas. Lai arī sociālās inovācijas nesaistās ar dārgiem zinātniskiem eksperimentiem, tomēr to iedzivināšana plašākā sabiedrỉbā var būt resursu ietilpịga.

Tāpat ir jāṇem vērā fakts, ka sociālo inovāciju atbalsts rezultēsies nevis konkrētos finansiālos ieṇēmumos, bet gan problēmu risinājumos, kas var paredzēt tā finansējuma ietaupijumu, kas ticis plānots problēmu risināšanai (Social Innovation Europe initiative, 2011). Piemēram, var izrādīties lētāk finansiāli atbalstīt sociālās inovācijas projektu, kas ierobežo narkotiku lietošanu jauniešu vidū, nekā maksāt par ārstēšanos un rehabilitāciju jeb sekām, kuras rada šì problēma. Minētajā piemērā sociālās inovācijas projekts neradīs peḷnu, bet radīs kopēju pozitīvu ietekmi uz budžetu un nākotnes ietaupijumus.

Nemot vērā valsts finanšu resursu ierobežojumus, ir jāapsver iespējas veidot kopīgas finansēšanas shēmas ar privāto sektoru, kas arī var būt būtiska ieinteresētā puse sociālo inovāciju atbalstam. Izveidojot sociālo inovāciju atbalsta iniciatīvu ASv, prezidents Baraks Obama (Barack Obama) norādīja, ka šim fondam ir jākombinē publiskie un privātie resursi, lai palìdzētu izaugtt daudzsološām iniciatīiām, kas spēj radīt labus rezultātus (Office of Social Innovation, n. d.)

Viena no iespējām atbalstīt sociālās inovācijas no valsts puses ir publiskais iepirkums. Valsts ir loti nozīmīgs dažādu preču un pakalpojumu pasūtìtājs, it īpaši tad, ja tie ir sociālie pakalpojumi. Lìdz ar to publiskajos iepirkumos var dot priekšroku sociālo inovāciju projektiem vai jau iepirkuma noteikumos noteikt, ka piegādātajam pakalpojumam ir jābūt inovatîvam.

Valsts sociālās inovācijas var atbalstīt arī citos veidos, ne tikai ar tiešu finansiālu palīdzību. Var lietot citus resursus, piemēram, neizmantotus nekustamos īpašumus, kas ir valsts rīcībā un var būt noderīgi sociālo inovāciju virzītājiem. Lielbritānijā tiek praktizēts neizmantotas telpas izīrēt par zemāku cenu sociālo inovāciju projektu autoriem (Boelman et al., 2014).

Visos sociālo inovāciju procesa posmos būtiski ir ne vien finanšu resursi, bet arì iespēja un vieta, kur mācīties no citiem, apmainīties ar idejām, meklēt nepieciešamos kontaktus un testēt sociālās inovācijas. Inovācijas procesos neatkarīgi no tā, vai tās ir tehnoloğiskās vai sociālās inovācijas, būtiska ir vide jeb sistēma, kurā tās notiek. Tāpēc valsts loma tiek saskatīta arī šādu apstāklu radīšanā. Lai atbalstìtu sociālo inovāciju procesus, valsts var organizēt sistemātiskus tīklošanās forumus vai kampaṇveidīgus pasākumus. Tāpat iespējams veidot arī sociālo inovāciju inkubatorus pēc analoğijas ar tehnoloğisko inovāciju inkubatoriem (OECD, 2010). Nereti šādas aktivitātes nodrošina nevalstiskās organizācijas, bet, ja tā nenotiek, tās var nodrošināt valsts. Piemēram, Masačūsetsas štatā katru gadu kampaṇveidīgi tiek izsludināts sociālo inovāciju mēnesis (Berzin et al., 2014).

Dažāda veida tīklošanās pasākumi ir būtiski. Lai sociālās inovācijas izdotos, ir nepieciešamas mazas un neatkarīgas ieinteresētās puses, kuras darbojas ar uzṇēmējdarbības garu, rada idejas un cenšas tās virzìt. Tāpa nepieciešamas arī lielas, stabilas, tradicionālas organizācijas kā valdỉbas, lielì uzñēmumi vai starptautiskas organizācijas, kas idejas var finansēt, testēt un iedzivināt (OECD, 2010). Tīklošanās forumi ir nepieciešami, lai apmainìtos a pieredzi darbā ar lielām organizācijām, kā arī lai iegūtu kontaktus tajās.

Sociālo inovāciju lomas izpratnei un jaunu ideju radīšanai OECD savās rīcibbpolitikas rekomendācijās norāda, ka šos jautājumus būtu nepieciešams ietvert arī skolu un augsstskolu mācību programmās, lỉdzịgi kā tiek praktizēts ar tehnolog̣isko inovāciju nozīmes apmācībām (OECD, 2010).

Lai atvieglotu sociālo uzṇēmumu darbỉbu, vairākās valstīs ir izveidotas speciālas šãdu uzṇēmumu reg̣istrācijas formas papildus tradicionālām uznēmējdarbības reğistrācijas formām. Kā piemēru no ASv var minēt mazienesiggas SIA (low protif limited liability companies) vai pabalsta korporācijas (benefit corporations). Šāda veida reg̣istrācijas formas visumā ir līdzigas tradicionālām reǵiistrācijas formām, bet atškiras ar to, ka, izmantojot šādu formu, galvenais uznēmuma uzdevums ir sociāls, bet peḷna ir sekundāra. Šìs formas 
uznēmumiem ir iespēja pretendēt uz speciālu grantu finansējumu, bet tajā pašā laikā tie nav atbrivoti no nodokḷu maksāšanas (Berzin at al., 2014). N̦emot vērā, ka sociālo inovāciju virzîtāji var būt cilvēki bez uzṇēmējdarbības pieredzes vai motivācijas, šādas atvieglotas juridiskās formas var papildus motivēt attīstīt sociālo inovāciju idejas.

Salīdzinoši nelielajā akadēmiskajā un cita veida literatūrā par valsts lomu sociālo inovāciju atbalstišanā bez apakšnodalıas sākumā minētās nepieciešamības veidot sociālām inovācijām labvēlīgu vidi vai ekosistēmu pastāv vienprātība par vēl vienu nepieciešamību. Proti, politikas veidotājiem ir jāturpina pētìt sociālo inovāciju fenomenu, lai radītu lielāku skaidrību par tā definīciju, par faktoriem, kas to ietekmē un sekmē, un par to, kāda var būt valsts loma šajos procesos.

Tāpat ir nepieciešams izvērtēt sociālo inovāciju procesu rezultātus, kā arī lỉdz šim ìstenotās valstu aktivitātes sociālo inovāciju atbalstam. Tieši šādu izvērtējumu rezultāti varēs parādīt, kāda ir valsts izmantoto instrumentu ietekme un vai un kas tajos būtu uzlabojams. Nepieciešams arī veidot starptautiskus salīdzinājumus, lai salīdzinātu dažādu instrumentu darbỉbu un sekmētu rīîibpolitikas mācišanos (OECD, 2010), jo pašlaik trūkst sistemātiski apkopotu datu par sociālo inovāciju procesiem dažādās valstīs un valsts lomu šajos procesos.

\section{Latvijas situācija}

Latvijā inovāciju jēdziens galvenokārt tiek izprasts tikai šaurajā tehnoloğisko inovāciju nozīmē. Tādi jēdzieni kā organizācijas pakalpojumu inovācijas, dizaina, mārketinga un arī sociālās inovācijas tiek lietoti, bet ne vienmēr izpratne par tiem ir pietiekama. Arī akadēmiskajā vidē sociālo inovāciju jēdziens Latvijāi ir jauns un publikācijas par šo tēmu ir retas. Savukārt šajā rakstā apskatītā problemātika, proti, valsts loma sociālo inovāciju atbalstam, ir cita starpā aplūkota tikai vienā publikācijā - Lāsmas Dobeles rakstā par faktoriem, kas ietekmē sociālās inovācijas Latvijā (Dobele, 2015).

Dobeles secinājumi par sociālo inovāciju situāciju Latvijā lielā mērā sakrīt ar nodaḷas autores vērojumiem. Proti, būtiskākais ierobežojums ir tas, ka nav apkopota informācija par situāciju Latvijā un trūkst sistemātisku datu. Minētajā rakstā viens no secinājumiem ir par to, ka Latvijā trūkst tiesiskā regulējuma sociālām inovācijām. Nodạ̣ā iepriekš jau minēti vairāku valstu piemēri tam, ka tiek izveidotas speciālas uzṇēmējdarbības reğistrācijas formas sociālajai uzneēmējdarbỉbai. Pēdējos gados Latvijā ir notikusi aktīva darbība šajā jomā, un 2017. gada oktobrī Saeima pieṇēma Sociālās uzṇēmējdarbības likumu (Latvijas Republikas Saeima, 2017).

Dobele arī norāda, ka sociālo inovāciju jomā Latvijā ir vāja koordinācija - gan rīcībpolitikas ziṇā, gan starp sociālās inovācijas ieinteresētajām pusēm (Dobele, 2015). Šajā kontekstā jānem vērā, ka koordināciju starp šīm pusēm var nodrošināt arī valsts institūcijas, organizējot tìklošanās forumus vai veidojot vietas, kur sociālajās inovācijās ieinteresētie dalībnieki var satikties. Tiesa, tas darāms, vispirms izvērtējot nevalstiskā sektora iespējas šādu koordināciju nodrošināt.

Valsts atbalsts sociālām inovācijām Latvijā nav sistemātiski analizēts. No vienas puses, var apgalvot, ka nekādi būtiski instrumenti sociālo inovāciju atbalstam Latvijā nepastāv. Latvijā nav specializētu sociālo inovāciju inkubatoru vai centru, nevar saṇemt finansējumu sociālo inovāciju projektiem, netiek organizēti konkursi vai stimulēta sabiedrības interese par šo jautājumu, kā redzams citu valstu piemēros. Taču, kā jau minēts iepriekš, sociālajām inovācijām būtiska ir vide, kurā tās notiek, un ne vienmēr no valsts puses ir nepieciešami kādi pasākumi, var pietikt arī ar to, ka valsts vienkārši netraucē sociālo inovāciju procesiem. Tāpēc bez padzilinātas analīzes nevar apgalvot, ka specifisku atbalsta instrumentu trūkums Latvijā nozimēe to, ka valsts nav draudzīga sociālām inovācijām.

Atsevišķi apskatot inovācijas jēdziena izpratni no normatīvā regulējuma viedokla, var secināt, ka tās sociālais aspekts vismaz formāli ir atzīts. Inovācijas jēdziens Latvijā ir definēts Zinātniskās darbības likumā: «inovācija-jaunu zinātniskās, tehniskās, sociālās, kultūras vai citas jomas ideju, izstrādṇu un tehnoloğiju îstenošana produktā vai pakalpojumā» (Saeima, 2005). Taču praksē, îpaši domājot par finansējuma avotiem sociālām inovācijām, šĩ definīcijā iekḷautā izpratne nav ìsti materializējusies.

Sabiedriskās inovācijas jēdziens ir lietots ilgtermina plānošanas dokumentā «Latvijas ilgtspējịgas attīstības stratēǵija līdz 2030. gadam» (Latvijas Republikas Saeima, 2010). Lai arī nosaukums «sabiedriskās inovācijas» atšḳiras, tomēr tā jēdzieniskā izpratne minētajā dokumentā sakrīt ar šeit apskatīto nozīmi. Stratēĝijā piedāvātas konkrētas un atbilstošas idejas praktiskai rīcībai, piemēram, portāls sabiedrības ideju apkopošanai, kā arī finansējums labu ideju attīstīšanai. Tāpat stratēǵijā piedāvāts izmantot nodạāa iepriekš apskatìto mehānismu, proti, ikgadējus apbalvojumus sociālo inovāciju autoriem. Vēl vairāk - piedāvāts arī izveidot institūciju, kas šis dažādās darbības koordinētu (Latvijas Republikas Saeima, 2010). Tiesa, trūkst analīzes par to, vai tas nebūtu iespējams bez jaunu institūciju izveides. Tāpat stratēogijā atzìta arì šajā rakstā apskatîto digitālo sociālo inovāciju loma.

Savukārt nacionālā līmeṇa vidējā termiṇa plānošanas dokumentā «Nacionālais attīstības plāns 2014.-2020. gadam» sociālai uzṇēmējdarbībai vai sociālām inovācijām nav veltìta nekāda uzmanība. Atškirībā no Zinātniskās darbības likuma, Nacionālās attīstības plānā inovāciju jēdziens lietots tikai šaurā tehnolog̣iskā izpratnē. Arī citos plāna rīcības virzienos nav aprakstīta iespēja problēmu risināšanā iesaistìt sabiedrïbu, kas varētu nākt klajā a jaunām idejām un panēmieniem. Piemēram, plāna rīcības virzienā «Vesels 
un darbspējīgs cilvēks» aprakstîtās problēmas saskanāà ar starptautisko literatūru ir pateicīgas, lai tās risinātu ar sociālo inovāciju palīdzību. Protams, jāṇem vērā, ka Nacionālās attīstỉbas plāns ir kodolīgs dokuments, kurā nav iespējams detalizēti aprakstìt visus iespējamos mehānismus, kas izmantojami sociālu problēmu risināšanai, varbūt tāpēc sociālo inovāciju jēdziens plānā neparādās. Turklāt, iespējams, plāna izstrādes gaitā tas nebija guvis atpazīstamību politikas veidotāju vidū. Tas, ka sociālo inovāciju jēdziens parādās tikai ilgtermina plānošanas dokumentā, nevis konkrētākajā Nacionālās attīstības plānā, varētu norādīt uz to, ka politikas veidotāij Latvijā pagaidām nav gatavi konkrētiem risinājumiem sociālo inovāciju atbalstam.

Iepazīstoties ar Eiropas Savienības struktūrfondu plānošanas dokumentiem Latvijā 2014.-2020. gada fondu periodam, var konstatēt, ka tie ietver sociālo inovāciju jēdzienu. Piemēram, «Partnerības līgums Eiropas Savienības investīciju fondu 2014.-2020. gada plānošanas periodam» paredz, ka atseviškas fondu investīcijas Latvijā tiks papildinātas ar Eiropas līmena iniciatīvu «Nodarbinātības un sociālās inovācijas programma» (Finanšu ministrija, 2014). Savukārt dokumentā, kas jau konkrētāk raksturo Latvijā plānotās ES fondu investīcijas, proti, darbỉbas programmā «Izaugsme un nodarbinātība», sociālām inovācijām ir veltita neliela atsevišḳa sadaḷa (Finanšu ministrija, 2014). Minētajā sadą̣ā norādīts, ka vairāku specifisko atbalsta mērḳu īstenošanā tiks ṇemtas vērā rekomendācijas no projektiem par aktīvu sabiedrības novecošanos un par bērniem ar funkcionāliem traucējumiem.

Cits tematisks virziens, kas apskatits darbibas programmas «Izaugsme un nodarbinātība» sociālo inovāciju sadạ̣ā, ir Latvijas viedās specializācijas stratēôija, kurai ir jābūt pamatā visām ES struktūrfondu investīcijām pētniecībā, attīstībā un inovācijās. Programmā sniegta norāde: «Viens no tās mērkiiem ir inovāciju komercializācijas veicināšana (tostarp eko un sociālo inovāciju).» (Finanšu ministrija, 2014) Šis gan ir savdabīgs formulējums, jo parasti jēdzienu «komercializācija» attiecina uz tehnoloğiskām, nevis sociālām inovācijām. Visbeidzot, šajā ES fondu plānošanas dokumentā norādīts: «Atbilstoši RIS3 3. prioritārā virziena «Mazo un vidējo komersantu konkurētspēja» SAM «Palielināt radošo industriju uzṇēmumu konkurētspēju» ietvaros plānots sniegt atbalstu arī inovatīvu sociālu pakalpojumu izstrādei un attīstỉbai, tādējādi veicinot sociālās izmaiṇas un sociālo problēmu risināšanu.» (Finanšu ministrija, 2014)

Balstoties uz minētajos dokumentos aprakstitajiem plāniem, Labklājības ministrija strādā, lai izveidotu sociālās uznēēmējdarbības atbalsta sistēmu. Tã ir sagatavojusi Ministru kabineta noteikumus, kas regulē ES struktūrfondu atbalsta piešķiršanu sociālajai uzṇēmējdarbībai Latvijā, un no 2016. lídz 202O. gadam isstenos pilotprojektu. Tā laikā tiks veidota un testēta sociālās uznēmējdarbỉbas atbalsta sistēma (Labklājības ministrija, 2017). Šāda pilotprojekta istenošana vērtējama pozitivi, un īpaši apsveicama ir plānotā atbalsta instrumentu ietekmes novērtēšana, taču plašāku vērtējumu šìm darbībām ir pāragri sniegt, ṇemot vērā, ka tās ir izstrādes procesā.

SOCIĀLO INOVĀCIJU PIEMĒRI LATVIJĀ Skaidrojot sociālus procesus, ir noderīgi izmantot piemērus, kas tos ilustrē. Autorei nav zināms sistemātisks un pilnvērtīgs apkopojums par Latvijā sastopamām sociālām inovācijām. Taču, izmantojot šì raksta sākumā dotās sociālo inovāciju definīcijas, var identificēt vairākus piemērus. Varētu gan strīdēties, vai turpmāk minētie piemēri ir vai nav sociālās inovācijas, jo, kā jau minēts iepriekš, sociālo inovāciju definīcijas ir dažādas. Latvijā identificējamie sociālo inovāciju piemēri aptver dažādas jomas - jauniešu aktivitātes, vides aizsardzibu, politisko lïdzdalību, invalīdu problēmas un citas.

Vides jomā viens no piemēriem, kas ir kampaņveidīgs, tomēr ar potenciālu ietekmi uz ilgtermina attieksmi pret apkārtējo vidi, ir ikgadējā Lielā talka. Talkas organizatori norāda: «Pasākuma ideja ir balstīta uz brīvprātīgu līdzdalību vides sakopšanā, radot saliedētību, pozitivismu un labi padarìta darba sajūtu. Lielās talkas idejas autore ir rakstniece Anna Žìgure, bet pati ideja aizgūta no igauniem, kas vides sakopšanu visas valsts mērogā pirmoreiz rīkoja 2008. gada 3. maijā.» (Lielās talkas portāls, 2017)

Lielās talkas piemērs rāda, ka sociālās inovācijas var pārṇemt no citām valstīm un sabiedrībām. Lai arī pasākums ir kampanveidīgs, tam ir potenciāls veidot ilgstošu sociālo praksi-kolektīvi atgādināt, ka apkārtējo vidi nevajag piesārṇot un ka ikkatrs var sniegt savu ieguldījumu tās tīrības nodrošināšanā. Šis piemērs parāda, ka sociālās inovācijas var radīt sociālas pārmainas. Minētais piemērs atbilst sociālo inovāciju definīcijās ietvertajam nosacijumam, ka tām ir jābūt vērstām uz sociālo labumu nodrošināšanu.

Sociālā inovācija, kas vērsta uz sabiedrības līdzdalības palielināšanu, ir lïdzdalības platforma/portāls manabalss.lv, kas dod iespēju vākt parakstus, lai Saeimai nodotu sabiedrības rosinātas likumdošanas iniciatīvas. Cita elektroniski bāzēta sociālā inovācija ir portāls ziedot.lv, kas palīdz organizēt lïdzekḷus no cilvēkiem, kuri ir gatavi palïdzēt citiem, kas nonākuši grūtībās. Portāla mājaslapā norādīts: «Ziedot.lv darbojas tajās jomās, kur valsts vai pašvaldỉbas finansējuma nav, vai tas ir nepietiekams, bet līdzcilvēkiem tik loti nepieciešams. Mūsu mērkịis ir radīt pozitīvas sociālās pārmainas un iesaistìt sabiedrību pašpalīdzībā. Katram iedzīvotājam ir jājūtas droši un grūtā brīdī jāsaṇem palīdzība, bet pārticības un labklājības brīdī jāspēj dalīties un palīdzēt savai tautai un valstij.» (Par ziedot.lv, 2015)

Manabalss.lv un ziedot.lv ir laba ilustrācija raksta sākumā paustajām norādēm par interneta lomu un digitālām sociālām inovācijām, kas, pateicoties internetam, ir aizvien iespējamākas. Abi piemēri noteikti ir raksturojami kā digitālas sociālās inovācijas. Tiesa, arī šajos gadījumos ir jānem vērā ierobežojumi, kas saistās ar digitālām sociālām inovācijām, proti, to izplatības 
ierobežojumi, jo informācijas tehnoloğijas nav vienlïdzīgi pieejamas visiem iedzīvotājiem, kā arī atšķiras to lietošanas prasmes.

Latvijā ne vien ir sastopamas sociālās inovācijas pakalpojumu jomā, bet arī tiek radīti produkti. Viens no piemēriem ir velosipēdi cilvēkiem ar īpašām vajadzībām Hopp, kas tiek pārdoti par pašizmaksu, un šis sociālais uzṇēmums arī ir piegādājis velosipēdus bērniem bez maksas labdarības kampaṇu laikā. Atbalstu šo velosipēdu radišanai ir sniegusi starptautiskā kompānija Narvesen (Narvesen atbalsta biedrïbu, 2012).

Minētie piemēri ir tikai atsevišķi gadijjumi, kas bijuši raksta autores redzeslokā un šeit izmantoti, lai ilustrētu sociālās inovācijas reālajā dzivēē Latvijā. Noteikti ir iespējams diskutēt par to, vai šie piemēri pilnībā atbilst sociālo inovāciju definīcijām, kā arì iespējams atrast daudzus citus piemērus šim fenomenam Latvijā. Tas ir turpmāku pētijumu uzdevums. Tāpat nav analizēts tas, vai un kāda ir bijusi valsts vai pašvaldību loma šo iniciativvu attīstībā, kas arī ir turpmākas pētniecības jautājums.

\section{Secinājumi}

Būtiskākais secinājums par sociālo inovāciju jēdzienu: tam ir samērā plaša definīija, un izpratne par to atškiriras atkarībā no zinātnes nozares, kas to pēta, un no plašāka konteksta, kurā par to runā. Jēdziens ir atvērts, un, iespējams, viena skaidra definīcija nav iespējama, īpaši ṇemot vērā to, ka vismaz atsevišķi pētnieki, kas minēti šì raksta pirmajā sadạ̦ā, uzskata, ka arī valsti var uzskatīt par vienu no iespējamiem sociāliem inovatoriem. Kaut gan pastāv dažādas definīcijas, ir pāris iezīmes, kuras ir kopīgas gandrīz visām sociālo inovāciju definīcijām. Būtiskākās no tām ir sociāla, nevis peḷnas motivācija, sociālo problēmu risināšana un jaunas pieejas sabiedrības problēmu risināšanā.

Paredzams, ka neskaidrais un izplūdušais sociālo inovāciju definējums vēl vismaz tuvākajā nākotnē apgrūtinās praktiķu, politikas veidotāju un pētnieku darbu. Viens no piedāvātajiem risinājumiem šai definīciju neskaidrībai ir koncentrēties uz jau zināmo par inovācijas procesiem un mēǵināt to piemērot sociālo inovāciju specifikai (Benneworth et al., 2014). Praktiski tas nozīmētu vairāk uzmanības pievērst tieši inovācijas daḷai sociālo inovāciju jēdzienā, lai labāk saprastu, kas ietekmē inovācijas procesus, un analizētu sistēmas, kurās inovācijas norisinās (Benneworth et al., 2014). Citi autori akcentē metodoloğijas problēmas sociālo inovāciju izpētei. Ja izpēte koncentrējas uz tirgus faktoriem, regulējumu un rīcibpolitiku, iespējams izmantot kvantitatìvas pieejas, bet, ja tā koncentrējas uz indivìdu motivācijām, uzvedību, tad ir iespējami rỉcības pētỉjumi un gadỉjumu analīze (Grimm et al., 2013).

Valsts loma sociālajās inovācijās galvenokārt izriet no tā, ka sociālajām inovācijām trūkst peḷnas motivācijas, bet tajā pašā laikā tās ir sabiedriski vēlamas, un tas rada motivāciju valstij stimulēt sociālo inovāciju procesus. Taču skaidrs ir tas, ka valsts darbības, kas vērstas uz sociālo inovāciju atbalstu, visticamāk, neveidos atsevišķu rīcībpolitikas jomu, bet gan papildinās citas rīcíbpolitikas vai būs neliela dạ̣a no tām. Arī institucionāli šis jautājums var tikt risināts dažādu nozaru ministrijās, un tas var radīt koordinācijas izaicinājumus, līdzīgi kā ir ar tehnoloğiskām inovācijām, kas arī nav saistāmas tikai ar vienas nozares atbildỉbu.

Šì jēdzieniskā neskaidrība traucē domāt par valsts lomu sociālo inovāciju atbalstam, un ir nepieciešami pētijumi par to, kāda veida atbalsts ir nepieciešams un kāda ir tā ietekme, lai veidotu pārdomātu rīcībpolitiku. Kaut arī šādas izpratnes trūkst, daudzviet pasaulē politikas veidotāji ir izpratuši sociālo inovāciju nozīmi un tiek ìstenotas dažādas aktivitātes to atbalstam.

Līdzīgi kā citur pasaulē, arī Latvijā sociālās inovācijas sabiedrībai, politikas veidotājiem un akadēmiskajai videi ir salīdzinoši nesens un jauns jēdziens ar visām no tā izrietošajām sekām. Tāpēc ir nepieciešams visām pusēm kopīgi veidot izpratni par šo fenomenu, jo netrūkst problēmu, kuru risināšanai varētu palīdzēt sabiedrïbas virzitas jaunas un inovatìvas pieejas. Sadarbojoties ar sociālo zinātṇu pētniekiem, politikas veidotājiem pastāy plašas iespējas izvērtēt to, kādi būtu labākie veidi, lai stimulētu sociālo inovāciju attīstību Latvijā. Kā rāda šajā nodaḷā apkopotā starptautiskā prakse, valsts iespējas stimulēt sociālās inovācijas ir ḷti plašas, un tam nebūt vienmēr nav nepieciešami loti lieli budžeta lïdzekli.

Lai gan pastāv vairākas problēmas un neskaidrības, kas saistītas ar ambiciozo sociālo inovāciju jēdzienu gan plašākā akadēmiskā un pētnieciskā kontekstā, gan rīcībpolitikas veidošanā, gan analizējot Latvijas situāciju, kopumā ir pamats likt lielas cerības uz to, ko aktīvāka sociālo inovāciju procesu norise potenciāli var sniegt mūsu sabiedrïbai.

\section{Izmantotie avoti}

Abad, A. G. (2014). Societies of Social Innovation. Voices and Arguments. Sussex Academic Press.

Benneworth, P., Amanatidou, E., Schachter, M.E., \& Gulbrandsen, M. (2014). Social innovation futures: beyond policy panacea and conceptual ambiguity. Position paper for the EU-SPRIforum. Retrieved from http://www.transitsocial innovation.eu/content/original/Book covers/Local PDFs/158 Paper Social innovation future beyond policy panacea and conceptual ambiguity 2014.pdf Berzin, S. C., Pitt-Catsouphes, M., \& Peterson, C. (2014). Role of State-Level

Governments in Fostering Social Innovation. Journal of Policy Practice, p. 13.

Boelman, V., Kwan, A., Lauritzen, J. R. K., Millard, J., \& Schon, R. (2014). Growing Social Innovation: A Guide for Policy Makers. A deliverable of the project: «The 
theoretical, empirical and policy foundations for building social innovation in Europe» (TEPSIE), European Commission-7th Framework Programme. Brussels: European Commission, DG Research.

Bonifacio, M. (2014). Social Innovation: a Novel Policy Stream or a Policy Compromise? An EU Perspective. European Review, 22, pp.145-169.

Bourgon, J.A. (2011). New Synthesis of Public Administration. Serving in the 21st Century. McGill-Queen's University Press, p. 77.

Caijaba-Santana, G. (2014). Social innovation: Moving the field forward. A conceptual framework. Technological Forecasting \& Social Change, p. 82.

Digital Social Innovation (2014). About Digital Social Innovation. Retrieved from http://content.digitalsocial.eu/about/

Dobele, L. (2015). Factors which influence the development of social innovation in Latvia. Proceedings of the 2015 International Conference «Economic science for rural development» No. 40. Jelgava, LLU ESAF, 23-24 April, pp. 226-238.

Eiropas Komisija (2013). Jauna ES nodarbinātības un sociālās politikas vispärīgā programma. Nodarbinātības, sociālo lietu un iekḷautības ǵenerāldirektorāts. Izgūts no http://www.lm.gov.lv/upload/aktualitates2/buklets_nsip.pdf

European Commission (2015). Growing Digital Social Innovation Ecosystem for Europe. A study prepared for the European Commission DG Communications Networks, Content and Technologies. Retrieved from http://www.nesta.org. uk/sites/default/files/dsireport.pdf

European Investment Fund (2016). EaSI Guarantee Financial Instrument. Retrieved from http://www.eif.org/what_we_do/microfinance/easi/index.htm

Finanšu ministrija (2014). Darbības programma «Izaugssme un nodarbinātība». Rīga. Izgūts no http://esfondi.lv/upload/Planosana/FMProg_270115_DP_2.pdf

Franz, H. W., Hochgerner, J., \& Howaldt, J. (2012). Challange Social Innovation. Potentials for Business, Social Entrepreneurship, Welfare and Civil Society. Springer, p. 4

Grimm, R., Fox, C., Baines, S., \& Albertson, K. (2013). Social innovation, an answer to contemporary societal challanges? Locating the concept in theory and practice. The European Journal of Social Science Research, 26, p. 4.

Hansson, J., Bjork, F., Lundborg, D., \& Olofsson, L.E. (2014). An Ecosystem for Socia Innovation in Sweden. A strategic research and innovation agenda. Lund University.

Labklājības ministrija (2017). Sociālā uznēmējdarbība. Izgūts no http://www.lm.gov. lv/text/3091

Latvijas Republikas Saeima (2010). Latvijas ilgtspējiğas attīstības stratêgíija līdz 2030. gadam. Izgūts no http://www.pkc.gov.lv/images/LV2030/Latvija_2030.pd

Latvijas Republikas Saeima (2017). Saeima galīgajā lasījumā lems par sociālās uzñèmējdarbïbas likuma projektu. Izgūts no http://www.saeima.lv/lv/ aktualitates/saeimas-zinas/2623o-saeima-galigaja-lasijuma-lems-parsocialas-uznemejdarbibas-likuma-projektu
Levesque, B. (2013). Social innovation in governance and public management systems: toward a new paradigm? In F. Moulaert, D. MacCallum, A. Mehmood, H. Hamdouch, The International Handbook on Social Innovation. Collective Action, Social Learning and Transdisciplinary Research. Edward Elgar Publishing.

Lielās talkas portāls (2017). Talkas ideja. Izgūts no http://talkas.lv/liela-talka/ Majumdar, S., Guha, S., \& Marakkath, N. (2015). Technology and innovation for Social Change. Springer India.

Minks, M. (2011). Social Innovation: New Solutions to Social Problems. A Thesis submitted to the Faculty of The School of Continuuing Studies and of The Graduate School of Arts and Sciences in partial fulfillment of the requirements for the degree of Master of Arts in Liberal Studies.

Moulaert, F., Martinelli, F., Swyngedouw, E., \& Gonzalez, S. (2005). Towards alternative model(s) of local innovation. Urban Studies (Routledge), p. 42.

Mulgan, G., Tucker, S., Ali, R., \& Sanders, B. (2007). Social Innovation: What is it, why it matters, and how it can be accelerated? London, UK: The Young Foundation.

Narvesen atbalsta biedrïbu «Latvijas bērniem ar kustïbu traucējumiem» (2012). Publicēts 19.07.2012. Izgüts no https://www.narvesen.lv/par-narvesen/ jaunumu-arhivs/4355/

OECD (2010). Social Entrepreneurship and Social Innovation. OECD. SMEs, Entrepreneurship and Innovation. OECD Publishing.

Office of Social Innovation and Civic Participation (n. d.). About SICP - The Community Solutions Agenda. Retrieved from https://www.whitehouse.gov/ administration/eop/sicp/about

Osburg, T., \& Schmidpeter, R. (2013). Social Innovation. Solutions for Sustainable Future. Springer, p. 174 .

Par ziedot.lv (2005). Izgūts no https://www.ziedot.lv/par-ziedot-lv

Partneribas lïgums Eiropas Savienibas investiciju fondu 2014.-2020. gada plānošanas periodam, 152.lpp. Izgūts no http://esfondi.lv/upload/Planosana/ FMPlans_230714_Partn_lig_ar_grozijumiem_17.12.2014.pdf

Passani, A., Spagnoli, F., Prampolini, A., \& Kilpi, K. (2015). Assesing the Social Impact of EU Funded Projects in the Digital Social Innovation Domain. Retrieved from http://5emesconf.exordo.com/files/papers/139/final_draft/paper EMES_Conference_Kilpi.pdf

Pol, E., \& Ville, S. (2009). Social Innovation: Buzz Word or Enduring Term? The Journal of Socio-Economics, $38(6)$, pp. 878-885.

Ross, F.J., \& Goddard, C. (2015). Unequal nation. The case for social innovation to work for a gender equal future. The Young Foundation.

Saeima (2005, 5. maijs). Zinātniskās darbibas likums. Pienemts 14.04.2005. Latvijas Vēstnesis, 70. Izgūts no http://likumi.lv/doc.php?id=107337

Saul, J. (2011). Social innovation, INC. 5 strategies for driving business growth through social change. Jossey-Bass. 
Segercrantz, B., \& Seeck, H. (2013). The construction of social innovation and undesirable consequences of innovation - a critical reading of the European Union's social innovation policy. Proceedings of the 2013 EU-SPRI Forum Conference, Madrid 10-12 April.

Social Innovation Europe initiative (2011). Financing Social Impact. Funding Social Innovation in Europe - mapping the way forward, p. 7. Published 23.11.2011. Retrieved from http://ec.europa.eu/growth/tools-databases/newsroom/ cf/itemdetail.cfm?item id=5582\&lang=en\&title=Financing-Social-Impact.Funding-social-innovation-in-Europe---mapping-the-way-forward

Wehn, U. \& Evers, J. (2015). The social innovation potential of ICT-enabled citizen observatories to increase eParticipation in local flood risk management. Technology in Society, p. 42

World Economic Forum (2013). Breaking the Binary: Policy Guide to Scaling Socia Innovation. Retrieved from http://www.weforum.org/pdf/schwabfound/ PolicyGuide to ScalingSocial Innovation.pdf

W.T.F. is Ghetto? Izgūts no http://www.ghettofamily.com/family/par_mums/ wtfisghetto/ 


\section{Pavirzišanas* iespējas veicināt dalību vēža savlaicīgas atklāšanas programmā}

* Nudging (angḷ val.)
Onkoloğiskās slimības ir otrs biežākais mirstības cēlonis Latvijā. 2014. gadā 57,03\% gadījumu mirstības cēlonis bija asinsrites sistēmas slimības un $21,57 \%$ gadijumu - audzēji (Slimïbu profilakses un kontroles centrs, 2015a). Saskañā ar Slimỉbu profilakses un kontroles centra datiem 2014. gada beigās Latvijā bija 77822 onkoloğisko slimību pacienti. Salīdzinājumam - 200o. gadā Latvijā bija 49269 onkoloğisko slimību pacienti. 2014. gadā no jauna tika reǵistrēti 11412 saslimšanas gadỉjumi (Slimïbu profilakses un kontroles centrs, 2015b).

Agrīnas diagnostikas gadijumā un pateicoties medicīnas attīstībai, arvien vairāk uzlabojas onkoloğisko slimību ārstēšanas iespējas. Pēdējos gados onkoloğiskās slimỉbas drīzāk tiek uzskatìtas par hronisku, ne akūtu stāvokli, tāpēc ir būtiski tās pēc iespējas ātrāk atklāt.

Eiropas Komisijas rekomendācijas paredz ieviest organizētas skrīninga programmas, un daudzās valstīs tās jau funkcionē (Camilloni et al., 2013). Skrīninga programmas ir efektivvas, lai agrīni, vēl pirms simptomu parādīšanās, diagnosticētu onkoloğiskās slimības un samazinātu iedzivotāju mirstību no ḷaundabīgiem audzējiem (Wardle et al., 2015). Tās ir efektīvas bieži sastopamiem laundabīgiem audzējiem, kuriem ir pieejami skrīninga testi iedzīvotāju grupām ar augstāku saslimšanas risku (Ministru kabinets, 2014).

No 2009. gada Latvijas iedzīvotājiem ir pieejama valsts finansēta vēža savlaicīgas atklāšanas programma. Programma ietver valsts finansētas krūts vēža, dzemdes kakla vēža un zarnu vēža profilaktiskās pārbaudes (Nacionālais veselības dienests, 2015). Programma paredz, pirmkārt, mamogrāfijas izmeklējuma veikšanu ik pēc diviem gadiem $50-68$ gadus vecām sievietēm,

t. i., 50, 52, 54, 56, 58, 60, 62, 64, 66, 68 gadu vecumā; otrkārt, dzemdes kakla pārbaudi reizi trijos gados $25-67$ gadus vecām sievietēm un, treškārt, zarnu vēža profilaktisko pārbaudi sievietēm un vïriešiem vecumā no 50 līdz 74 gadiem. Lai veiktu krūts vēža un dzemdes kakla vēža profilaktiskās pārbaudes, Nacionālais veselïbas dienests nosūta uzaicinājuma vēstuli attiecīgā vecuma sievietēm, savukārt, lai veiktu zarnu vēža profilaktisko pārbaudi, jāvēršas pie ğimenes ārsta.

Nopietna problēma ir iedzivvotāju zemā atsaucība dalībai valsts finansētajā programmā. Tabulā apkopoti dati par pēdējo piecu gadu rezultātiem. Atsaucība uz krūts vēža un dzemdes kakla vēža skrinningu svārstās 30-35\% intervālā, savukārt zarnu vēža skrīninga atsaucības augstākais rādītājs ir tikai ap 10\%. Lai programma būtu efektivva, nepieciešams, lai profilaktisko pārbaudi veiktu vismaz 75\% iedzīvotāju, kas saṇēmuši uzaicinājumu (Ministru kabinets, 2014).

Tā kā krūts vēža, dzemdes kakla vēža un zarnu vēža skrinninga gadijjumā ir atšḳirīgi iespējamie zemās atsaucības iemesli, piemēram, dzimums, vecums, informētība, veselības pakalpojuma pieejamība u.c., tālāk rakstā izmantoti dati tikai par dzemdes kakla vēža skrīningu. Nacionālā veselības 
Tabula. Atsaucība uz aicinājumu veikt vēža skrīningu (\%)

\begin{tabular}{lcccccc}
\hline & 2011 & 2012 & 2013 & 2014 & 2015 & 2016 \\
\hline Krūts vēža skrīnings & 33,8 & 32,7 & 34,2 & 35,9 & 34,9 & 27,4 \\
\hline Dzemdes kakla vēža skrīnings & 34,5 & 26,7 & 27,4 & 27,8 & 25,0 & 25,2 \\
\hline Zarnu vēža skrinings & 7,09 & 7,63 & 9,64 & 10,59 & 10,9 & 11,8 \\
\hline
\end{tabular}

(Nacionālais veselibas dienests, 2016)

dienesta Ambulatoro pakalpojumu nodaḷas vadītāja Lỉga Gaigala (Gaigala, intervija, 12.10.2015.) skaidro - lai arī vienā gadā uzaicināto aptvērums dzemdes kakla vēža skrīninga gadỉjumā ir ap 30\%, tomēr trīs gadu laikā tiek sasniegts $74 \%$ populācijas aptvērums, kas nozīmē, ka trīs gadu laikā $74 \%$ sieviešu vismaz vienu reizi ir veikts onkocitoloğiskais izmeklējums. Tomēr šo nevar uzskatît par apmierinošu rezultātu, jo sievietes ārstu biežāk apmeklē problēmu gadijjumā, ne profilaktiski.

Pēdējos gados arvien vairāk palielinās rīcībpolitikas veidotāju, darba devēju, apdrošinātāju un veselības aprūpes sniedzēju interese par uzvedības ekonomistu un psihologu pētîto spriedumu un lēmumu pieņemšanas principu lietošanu praksē, lai mainītu un uzlabotu cilvēku dzīves stilu, paradumus un veselības uzvedỉbu. Viens no panēmieniem, kam veselïbas uzvedības veicināšanā arvien vairāk pievērš uzmanību, ir pavirzī̌sana. Gan pētnieki, gan dažādu valstu veselības politikas veidotāji to izmanto kā inovatīvu politikas instrumentu. Nodalas mērkis ir izpētìt, kādas ir iespējas izmantot pavirzī̌sanu, lai veicinātu iedzīvotāju dalību vēža savlaicīgas atklāšanas programmā. Tika izanalizēta situācija, lai izstrādātu tādus pamudinājumus, kas veicinātu uzaicināto personu ierašanos uz veselïbas pārbaudi.

\section{Pavirzišana, tās definēšana}

un veidi rezultātā iespējami būtiskāk palielināsies viṇa ieguvums. Tomēr cilvēki ne vienmēr rīkojas racionāli un ne vienmēr cenšas palielināt savu ieguvumu un labumu. Tieši otrādi-cilvēki bieži pieṇem lēmumus, kas nav viṇu interesēs, un tas notiek vājas paškontroles vai prokrastinācijas, vai arī pārāk sarežğìitas informācijas dēl u.c. (Mont, Lehner, \& Heiskanen, 2014). Uzvedības ekonomikā tiek ṇemts vērā, ka realitātēe individu spriedumi, lēmumi un no tiem izrietoša rīcība prognozējamā veidā ir kḷūdaina vai neobjektīva (Blumenthal-Barby \& Burroughs, 2012).

Cilvēki nav perfekti lēmumu pieṇēmēji, un bieži vien aptverošas izmaksu un ieguvumu analizzes vietā lieto mentālos îsceḷus, kas rada kḷūdas un neobjektivitātes. Tendence sevi kognitīvi nepiepūlēt ir saistìta ar to, ka lielākā daḷa ikdienas rutīnas lēmumu tiek pieņemti, izmantojot domāšanas 1. sistēmu (ātra, automātiska, intuitīva), savukārt, pieņemot komplicētus un nozīmīgus lēmumus, parasti tiek izmantota domāšanas 2. sistēma (lēna, apzināta, sistemātiska), kas no indivìda prasa lielāku kognitīvo piepūli (Kahneman, 2003; Kahneman, 2011).

Nemot vērā šos spriedumu un lēmumu pienemšanas trūkumus, indivīdu uzvedību ir iespējams ne tikai labāk izprast, bet arī izmantot, lai to mainītu un palīdzētu veikt labākas izvēles. To sauc par pavirzišanu. Pavirzišana ir izvēḷ arhitektūras aspekts, kas maina cilvēku uzvedību prognozējamā veidā, neaizliedzot citas izvēles iespējas (Thaler \& Sunstein, 2008). Tie ir netieši ieteikumi, lai mēǵinātu bez piespiešanas ietekmēt grupu un indivìdu motīvus, stimulus un lēmumu pieṇemšanu un palīdzētu veikt labākas izvēles, lai vinu dzīve būtu veselīgāka, labklājiḡāka un laimīgāka. Piemēram, auglu nolikšana acu līmenī, lai piesaistītu uzmanību un palielinātu aug̣̣u izvēles iespēju, ir pavirzišana, savukārt neveselīgas pārtikas aizliegšana-nav.

Šo definiciju zinātnieki ir plaši apsprieduši, un viens no uzskatiem ir, ka tā ir pārāk plaša un neprecīza (Mont et al., 2014). Viena no alternatīvām definīcijām ir šāda: «pavirzišana ir jebkurš mēǵinājums prognozējamā veidā ietekmēt cilvēku spriedumus, izvēles vai uzvedỉbu, ko iespējamu padara domāšanas neobjektivitātes un klūdas, kas rada barjeras lēmumu pienemšanā un traucē cilvēkiem rīkoties racionāli vinu pašu interesēs» (Hansen, 2014, p. 2). Savukārt cita plašāka definīcija aptver ne tikai ekonomiskos, bet arī citus stimulus: «pavirzišana ir izvēles ietekmēšana, neierobežojot izvēlu komplektu vai nepadarot izvēḷu alternatīvas ievērojami neizdevīgākas laika, grūtības, piepūles u.c. ziṇā» (Hausmann \& Welch, 2010).

Pēdējo desmit gadu laikā arvien vairāk pieaug interese par uzvedības ekonomikas un psiholoğijas pētijumu rezultātiem un to lomu cilvēku uzvedības, dzīves stila un paradumu izprašanā. Padzị̣ināta izpratne par šiem jautājumiem var palīdzēt rīcībpolitikas veidotājiem, lai viṇu piedāvātie risinājumi būtu reālistiskāki un efektīvāki.

Dažu valstu valdības ir izveidojušas pētnieku un speciālistu grupas, kas izmanto jaunāko zinātnisko pētỉjumu rezultātus, lai viṇu veidotās rīcībpolitikas būtu sekmigākas. Lielbritānijas valdība ir izveidojusi Uzvedības izpratnes grupu (The Behavioural Insights Team), kuras mērḳis ir uzlabot rīcībpolitiku rezultātus, ṇemot vērā reālistiskākus cilvēku uzvedības modeḷus, un, kur vien iespējams, veicināt, lai cilvēki izdarìtu labākas izvēles par sevi un savu dzivvi. Amerikas Savienoto Valstu valdỉba 2015. gadā ir izveidojusi Sociālo 
un uzvedïbas zinātnu grupu (Social and Behavioral Sciences Team), kuras galvenais izdevums ir izskaidrot sociālo un uzvedỉbas zinātṇu secinājumus un metodes rīcibpolitiku un programmu uzlabošanai.

Pavirzišsana daudzviet tiek izmantota kā inovatīvs politikas instruments, un arī Latvijā ir iespēja pavirzišanu izmantot rīcībpolitiku veidošanā, t. sk. veselības politikā. Uzvedības ekonomika piedāvā instrumentus, kas var palielināt cilvēku dalību vēža savlaicīgas atklāšanas programmā.

Ar veselību saistìtus lēmumus var iedalīt divās dạ̣ās - rīcībpolitikas lēmumi, kas ietekmē plašākas cilvēku grupas, piemēram, kā sadalīt ierobežotus finanšu resursus (Li \& Chapman, 2013), un individa personiskie lēmumi, piemēram, vakcinēties pret ērču encefalītu, lietot uzturā dārzenus u.c. Bet ar rīcībpolitikām ir iespējams ietekmēt arī individuālo lēmumu pieņemšanu.

Tālāk aplūkoti biežāk zināmie un izmantotie pavirzīšanas veidi, kuri var ietekmēt individa lēmumu pien̦emšanu un kurus var izmantot, lai mainìtu cilvēku uzvedību un palìdzētu izdarìt labākas izvēles.

vēstNesıs Cilvēki piešķir dažādu nozīmi informācijai atkarībā no tā, kurš to sniedz, un seko dažādas reakcijas (Dolan et al., 2010). Piemēram, tas, vai informāciju sniedz formāla vai neformāla autoritāte, vienaudži vai draugi, - var radīt atšķirìgus rezultātus. Dažkārt cilvēkus ietekmē tas, kādas izjūtas viṇiem ir pret informācijas sniedzēju, un mēdz iracionāli ignorēt informāciju, kuru sniedz kāds, kas tiem nepatìk. Piemēram, jāizvērtē, vai vienmēr informācija jāsniedz oficiālām valsts iestādēm, jo dažkārt ir labāk, ja informēšanas kampaṇu veic kāda trešā puse. Saistībā ar veselības jautājumiem noderīgi/efektīvi var būt citu iedzìvotāju personiskie stāsti vai piemēri.

SOCIĀLĀS NORMAS Sociālās normas ietekmē cilvēku uzvedỉbu, piemēram, tas, kā rīkojas citi, vai cilvēka paša uzskati par to, ko citi no viṇa sagaida (Purnell et al., 2015). Ja sociālā norma ir vēlama, tad cilvēki drīzāk par to ir jāinformē, savukārt jābūt piesardzīgiem ar nevēlamām vai kaitīgām sociālām normām, jo to pieminēšana var radīt apgrieztu rezultātu (Dolan et al., 2010). Piemēram, sniedzot iedzivotājiem informāciju par vidējo ūdens patēriṇu ēkā, tie, kuri tērē mazāk, ieraugot, ka vidējais patēriṇš ir lielāks, nereti sāk tērēt vairāk. Tipiski sociālo normu izmantošanas piemēri ir «lielākā daḷa iedzīvotāju nodokḷus samaksā laikā» vai «deviṇi no desmit viesnīcas viesiem dvielus lieto atkārtoti» (Sunstein, 2014). Cilvēki tiek informēti par citu cilvēku uzvedību noteiktās situācijās. Vēl viens piemērs ir informācijas sniegšana par veselības risku ne absolūtos, bet ar cilvēku saistitos rādītājos. Piemēram, formulējums «Jums ir 30\% krūts vēža risks, un lielākajai dalai cilvēku tas ir $10 \%$ » būs iedarbīgāks vēstijjums nekā «Jums ir 30\% krūts vēža risks» (Lipkus et al., 2005).

SAISTİBU UZNEMŠANĀS UN SOLĪJUMI Individi bieži vien prokrastinē, pat ja tas nav vinuu ilgtermina interesēs. Dažkārt ir vieglāk sasniegt
Šajā gadijumā ar diskontēšanu jāsaprot tendenco izvēlēties mazāku, bet tūlitēju ieguvumu lielāka ieguvuma vietā nākotnē. mērki, piemēram, pārtraukt smēkēt, ja par to tiek noslēgta vienošanās vai paziṇots publiski. Ja cilvēki uzṇemas saistības, viṇi drīzāk rīkosies saskaṇā ar savu mērḳi. Vēl labāk, ja tiek nosprausts precīzs mirklis, kad darbibba tiks sākta (Sunstein, 2014). Publiski solījumi padara cilvēku rīcību iespējamāku, jo individam ir svarīgi būt konsekventam un ievērot solīto.

EMOCıjAs Emocionālām reakcijām var būt nozìmìga ietekme uz lēmuma pienemšanu, un tās var ietekmēt cilvēku rīcību (Slovic et al., 2002). Piemēram, bailes no vēža var veicināt izvairīšanos no vēža skrīninga vai veselības pārbaudēm. Lai arī iebiedēšana dažkārt tiek uzskatīta par ḷoti iedarbỉgu lïdzekli, tomēr uzvedības maina var nenotikt -indivīdi turpinās uzvesties tāpat, bet būs daudz trauksmaināki vai bailīgāki (Purnell et al., 2015). Tāpēc iedarbigga pieeja var būt formulēt vēstījumus tā, lai veicinātu pozitìvas emocijas par skrīningu vai novērstu negativas emocijas. Piemēram, aprakstì atvieglojuma izjūtas, kādas būs, zinot par savu veselības stāvokli, vai lepnumu, ka cilvēks rūpējas par savu veselïbu.

EGO Cilvēkiem ir raksturigi rìkoties tā, lai gūtu pozitivu priekšstatu par sevi. Tipiski, ka sekmīgās situācijās cilvēki panākumus piedēvē sev, savukārt neveiksmēs vaino citus cilvēkus vai apstākḷus. To sauc arī par pamata atribūcijas kḷūdu, kas nozīmē tendenci pārvērtēt uzvedības dispozicionālus skaidrojumus un nenovērtēt situatīvus skaidrojumus. Ego ir nozīmīga loma daudzos pavirzišanas gadījumos, piemēram, viens no ieteikumiem ir novietot spoguḷus pie neveselīga ēdiena.

NĀKOTNES IEGUVUMU DISKONTĒŠANA ${ }^{1}$ Cilvēki parasti dod priekšroku mazākam tūlītējam labumam, nevis lielākam labumam vēlāk (Frederick \& Loewenstein, 2002). Cilvēku uzvedībai raksturīga hiperboliskā diskontēšana, nevis eksponenciālā diskontēšana, un tas nozimēe, ka diskonta likme nav vienmērīga. Izvēlē starp ieguvumu tagad un vēlāk ir augsta diskonta likme, kas nozīmē priekšroku mazākam tūlītējam labumam, savukārt izvēèē starp vēlāk un vēl vēlāk diskonta likmes ir daudz zemākas un indivìdi parast izvēlas lielāku un vēlāku ieguvumu. Tā kā individs drīzāk izvēlēsies tūlìtēju, nevis ilgtermiṇa ieguvumu, tad saistībā ar skrīningu ir noderīgi runāt par tūlìtējiem ieguvumiem, piemēram, mierīgs prāts par savu veselību vai iespèja novērst vēzi (Purnell et al., 2015).

NoKLUsējums Indivìdi biežāk izrāda mazāku pretestību gadijumos, kad nekas nav jādara, kad var saglabāt esošo situāciju un prokrastinēt. Izvēle pēc noklusējuma ir tendence pieñemt esošo stāvokli, kad kāda izvēles iespēja tiek piedāvāta kā standarta. Vēlamã uzvedỉba tiek piedāvāta automātisk pēc noklusējuma, un, lai izvēelētos citu iespēju, ir nepieciešama aktīva darbība (Purnell et al., 2015). Tāpēc ir iespējams iepriekš noteikt izvēles, kas veicina veselību un labklājību, piemēram, ārsti var mudināt savus pacientus regulāri veikt vēža skrīningu, nosakot pieraksta datumu un laiku pēc noklusējuma. 
Lai atteiktos, pacientam ir jāzvana un jāatcel vizìte. Svarīgi ir atzīmēt, ka indivĩdam ir iespēja atteikties no noklusējuma izvēles. Biežāk minētais noklusējuma piemērs ir orgānu donoru programma. Valstīs, kurās pēc noklusējuma indivīds ir iesaistīts orgānu donoru programmā, ir daudz augstāki dalības rādītāji nekā valstīs, kurās personai jāizdara aktīva izvēle, lai piedalìtos programmā (Johnson \& Goldstein, 2003; Mont et al., 2014).

KADRÉĚANA Vienu un to pašu informāciju var dažādi pasniegt (Purnell et al., 2015). Tas nozimēe informācijas pasniegšanu, aktivizējot noteiktas individa vērtības un attieksmes (Mont et al., 2014). Zināmā mērā kadrēšana nozīmē atsevišķu aspektu izvēli un to akcentēšanu. Piemēram, atkarībā no konteksta cilvēks nereti izvēlas dominējošo iespēju vai arī, ja nekas nedominē, tad vidējo starp divām galējām iespējām (Purnell et al., 2015).

PRAIMINGS JEB IEPRIEKšĒeja SAGATAVošana Cilvēku rīcību ietekmē tas, kā vini tiek sagatavoti pirms rīcỉbas (Dolan et al., 2010). Cilvēku rīcību ietekmē dažādi norādijiumi un mājieni, un šos mājienus var izmantot, lai viṇus sagatavotu veselības uzvedībai. Piemēram, aug̣̣u un dārzeṇu patēriṇš skolu êdnīcās pieaug, ja tos novieto redzamās un viegli pieejamās vietās. Cilvēki biežāk izmantos kāpnes, ja tās ēkā būs iepretim durvīm un lifts būs pieejams tālāk nekā kāpnes (Blumenthal-Barby \& Burroughs, 2012). Pat vienkārši jautājumi par veselības paradumiem var palielināt vai samazināt konkrētajai uzvedībai raksturīgo darbību skaitu, piemēram, ja cilvēkiem uzdod jautājumu, vai viṇi plāno nākamajā nedēḷā lietot treknu pārtiku, viṇi šādu pārtiku lietos mazāk (Thaler \& Sunstein, 2008). Cilvēki daudz vairāk iesaistās aktivitātēs, ja kāds pajautā par vinu nodomiem, piemēram, «vai jūs plānojat vakcinēt savu bērnu?». Tāpat var uzsvērt iepriekšējo rīcību, piemēram, «kā rāda jūsu iepriekšējā rīcība, jūs esat vēlētājs» (Sunstein, 2014).

NePATIKA PRET ZaUdējumiem Saskaṇā ar izredžu teoriju cilvēki cenšas izvairîties no zaudējumiem, kā arī daudz spēcīgāk reaǵē uz zaudējumiem nekā uz tāda paša apjoma ieguvumiem (Kahneman, 2011). Piemēram, emocionāli nepatīkamāka būs 20 eiro zaudēšana nekā tādas pašas summas iegūšana. Tādēl stimuli ir daudz efektivāki, ja tie tiek formulēti zaudējuma terminos. Tomēr saistībā ar skrīningu ne visi pētỉjumi liecina par lielām atškiriībām - kadrējot krūts vēža skrīninga vēstijumu zaudējuma terminos, var būt minimāla priekšrocỉba salīdzinājumā ar ieguvuma terminos kadrētu vēstijumu (O’Keefe \& Jensen, 2009).

CILVĒKI PĀRVĒrté nelielas varbūtības Cilvēki neuztver varbūtību izmaiņas lineārā veidā un saskaṇā ar ekonomikas teoriju. Piemēram, piecu procentu pieaugums starp 5\% un 10\% nav tāds pats kā starp 50\% un 55\%. Tas nozimēe, ka loterija var motivēt veselïbas uzvedībai, jo cilvēki pārvērtē laimēšanas iespējas (Dolan et al., 2010).

RELJEFUMS (SALIENCE) Cilvēku uzmanība ir vērsta uz jauno un svarīgo. Pieṇemot lēmumus par veselību, cilvēkus bieži vien ietekmē jauni,

personiski svarīgi vai spilgti piemēri un skaidrojumi. Piemēram, ja ēdienkartē tiek norādītas kalorijas, tad cilvēki vairāk iegādājas ēdienu, kas satur mazāk kaloriju, līdz ar to restorāniem ir izdevigi samazināt kaloriju daudzumu ēdienā (Blumenthal-Barby \& Burroughs, 2012).

INFORMĀCIJAS VIENKĀRŠOŠANA Nereti pasniedzamā informācija ir sarežğita, un tas savukārt ietekmē cilvēku pieṇemtos lēmumus. Informācijas vienkāršošana var mainīt lēmumus, jo tā tiek pasniegta saprotamākā veidā, kas labāk atbilst indivīda uztveres spējām un lēmumu pienemšanas procesam (Mont et al., 2014). Vienkāršošanas iespējamo ietekmi nereti nepietiekami novērtē (Sunstein, 2014). Lìdzīgi vēlamo rīcību var veicināt, ja to padara viegli pieejamu un tiek samazinātas barjeras, piemēram, laika patērinš, ko tā prasa. Ja vēl vieglākā un ērtākā izvēle ir jautra vai patìkama, cilvēki to labprāt izvēlas (Sunstein, 2014).

BRĪDINĀJUMI UN ZİMES Dažkārt pavirzišana var izpausties arī kā personisks vai publisks brīdinājums, piemēram, lieli burti un spilgtas krāsas var noderēt, lai pievērstu cilvēku uzmanību. Lai arī cilvēkiem ir tendence ignorēt brīdinājumus («ar mani viss būs labì), tomēr pētijumi rāda, ka, pievienojot brīdinājumam konkrētas rīcības aprakstu, kā var samazināt risku, brīdinājumi tiek ignorēti retāk, piemēram, «Jūs varat darìt X un Y, lai samazinātu risku Z» (Sunstein, 2014). Cits piemērs ir norādes populārās tūristu vietās Londonā - «skaties pa labi» (gan brīdinājums, gan sagatavošana) - un tās ir samazinājušas negadijumu skaitu (Thaler \& Sunstein, 2008).

ATGĀDINĀJUmı Piemēram, e-pasta vēstule vai ìsziņa par kavētiem maksājumiem, gaidāmiem pienākumiem vai tikšanos. Tas palīdz inerces, prokrastinācijas, konkurējošu pienākumu un aizmāršỉbas gadỉjumos. Svarīgs ir atgādinājuma laiks, lai gaidāmā uzvedība atkal netiktu atlikta un indivìds rïkotos tūlīt (Sunstein, 2014). Vēža skrīninga gadijjumā iedarbīga varētu būt atgriezeniskā saite pēc veikta skrininga vai automātisks atgādinājums, ka pārbaude nav veikta (Purnell et al., 2015).

Pavirzišanas kritika un ētiskie apsvērumi sen, 2013). No vienas puses, juridiskās zinātnes un politikas zinātnes pētnieki pavirzī̌anu kritizē, savukārt citu jomu pētnieki, t. sk. uzvedības pētnieki, psihologi un veselības jomas pētnieki, tomēr saredz iespēju izmantot pavirzišanu cilvēku labumam, ja vien tiek ṇemti vērā ètiskie apsvērumi. Pavirzìšana tiek kritizēta par to, ka tā ir bīstama demokrātiskam procesam, un daži pētnieki to sauc par manipulāciju, kas apdraud indivĩda autonomiju (Mont et al., 2014). Daudzās publikācijās pavirzišana tiek aplūkota kā libertārais paternālisms, jo tā vada cilvēku noteiktā virzienā, kas veicina vinu labklājību, 
tomēr cilvēkiem ir brīviba atteikties un pašiem izvēlēties sev vēlamo (Sunstein, 2014), lai arì izvẹḷu arhitektūra ir veidota tā, lai veicinātu vēlamo uzvedỉbu (Mont et al., 2014).

Pētnieku atbilde pavirzišanas kritikiem visbiežāk ir, ka cilvēkiem joprojām ir iespēja izvēlēties un viṇiem šì iespēja netiek liegta, lai arī viṇi tiek pavirzìti veselīgākas izvēles virzienā. Viṇi joprojām var izvēlēties nevakcinēties, neveikt vēža skrīningu, ēst neveselīgu pārtiku u. c. Pavirzišanas atbalstītāji labi apzinās, ka tiek izmantota cilvēku nespēja vienmēr būt racionāliem, tomēr tā tiek izmantota cilvēku labā. Netiek mainìta izvēles iespēja, bet tiek mainìta lēmuma vide, un indivìds tiek pavirzìts, lai būtu vieglāk izvēlēties optimālo iespēju (Li \& Chapman, 2013). Ir situācijas, kurās pavirzišana dod lielāku labumu nekā kritikas respektēšana (Mont et al., 2014).

Iedzīvotājiem no pavirzišanas ir divu veidu labums: pirmkārt, vadlīnijas sarežğitu lēmumu piennemšanā un, otrkārt, iespēja noraidìt izvēles, kad tās ir pretējas individa labumam (Mont et al., 2014). Vēl viens ieguvums ir nelielās izmaksas. Veselïbas uzvedības izglìtibas programmas prasa pietiekami lielas izmaksas un ilgāku laiku, lai sasniegtu efektu, taču pavirzišana nerada papildu izmaksas un kopumā ir iespējams ietaupìt (Li \& Chapman, 2013).

Tālāk aplūkoti ētiskie apsvērumi, kas jāṇem vērā, izmantojot pavirzìšanu. Tai jābūt caurskatāmai, atklātai, un tā nedrikst būt piespiedu kārtā. Ikvienam individam jābūt iespējai izvairìties no pavirzīšanas (Sunstein, 2014) vai rìkoties pretēji pavirzišanas virzienam (Blumenthal-Barby \& Burroughs, 2012). Piemēram, noklusējuma gadỉjumā jābūt vienkāršai iespējai atteikties no automātiskās izvēles.

Pavirzī̌̌anai nekad nevajadzētu klūt par manipulāciju vai blēdīšanos (Sunstein, 2014). Nav piemēroti izmantot neprecīzus vai aplamus datus, piemēram, teikt, ka deviṇi no desmit cilvēkiem ir veikuši vēža skrīninga pārbaudi, lai gan tā nav patiesība. Pat ja tas kādu motivētu skrīningam, meli nav ētiski piel̦aujami. Nepietiek tikai ar labiem nodomiem. Jebkurai pavirzišanai jābūt balstītai uz pierādijjumiem (Blumenthal-Barby \& Burroughs, 2012).

Pavirzišanai vienmēr jābūt cilvēka labā, bet tas ne vienmēr ir iespējams. Piemēram, var uzskatìt, ka ir labi, ja cilvēks zina visu informāciju par savu veselības stāvokli, tomēr tam var būt arī psiholoğisks kaitējums, uzzinot par vēža diagnozi - gan viltus pozitìvas, gan viltus negatīvas atbildes gadijjumā. Tāpēc jābūt sagatavotiem sniegt nepieciešamo atbalstu šādās situācijās.

Pavirzīšana kā panēèmiens dalības veicināšanai vēža savlaicīgas atklāšanas programmā
Lai varētu sniegt priekšlikumu par piemērotākajām pavirzišanas metodēm vēža skrīninga apmeklējuma uzlabošanai, vispirms nepieciešams aplūkot zemas atsaucības iespējamos nozīmīgākos iemeslus. Lai to izdarìtu, tika izmantoti 1) pētījumi par citu valstu pieredzi; 2) Nacionālā veselības dienesta un Slimību profilakses un kontroles centra publiski pieejamie statistikas dati; 3) 2012. gadā veiktais pētijums par dzemdes kakla vēža savlaicigas atklāšanas programmas apmeklētỉbu ietekmējošiem faktoriem Vidzemes reǵionā, kur tika aptaujātas 548 sievietes (Stupele, 2012); 4) intervija ar Nacionālā veselības dienesta Ambulatoro pakalpojumu nodaḷas vadītāju; 5) 2015. gadā veiktās 10 intervijas ar sievietēm par vinu pieredzi saistỉbā ar vēža savlaicīgas atklāšanas programmas izmantošanu.

Ietekmējošos faktorus var iedalīt iekšējos un ārējos faktoros. Analīzē uzmanība pievērsta iekšejjiem faktoriem, detalizētāk aplūkojot tos, kuri saistìti ar lēmumu pienemšanu un uzvedību. Iekšējie faktori ir vairāki sociāldemogrāfiskie un ekonomiskie rādītāji (Stupele, 2012): vecums, izglìtība, ienākumu līmenis, dzīvesvieta, valoda. Tāpat pie iekšējiem faktoriem pieskaitāmi emocionālie un uzvedības aspekti, piemēram, bailes un laika plānošana (laika trūkums). Ārējie faktori ir saistīti ar veselïbas aprūpes sistēmu, organizatoriskiem skrīninga jautājumiem u.c., piemēram, rindas, veselības aprūpes pakalpojumu pieejamība, ǵimenes ārsta loma u.c. (Stupele, 2012). Analīzē aplūkoti tie faktori, kurus būtu iespējams ietekmēt un lỉdz ar to mainìt sieviešu uzvedību (saistībā ar izglìtošanas un informēšanas kampaṇām, veselības aprūpes sistēmu), bet nav aplūkoti pārējie faktori, kuri arī ir svarīgi, tomēr ne šajā pētijumā (indivìdu uzvedība).

Vidzemē veiktajā pētījumā tika konstatēta saistība starp skrīninga veikšanu un šādiem faktoriem: ienākumu līmenis (sievietes ar zemākiem ienākumiem biežāk izmanto valsts apmaksāto skrinninga izmeklējumu), zināšanu un izpratnes limmenis par dzemdes kakla vēža skrīningu (sievietes ar labāku izpratnes līmeni biežāk veic dzemdes kakla vēža skrīningu) (Stupele, 2012). Pārējie sociāldemogrāfiskie un ekonomiskie rādītāji neparāda statistiski nozīmīgas saistỉbas, kas lautu spriest par to lomu vēža skrīninga veikšanā.

Viens no bieži minētiem ietekmējošiem faktoriem ir bailes - gan no diskomforta izmeklējuma laikā, gan no iespējamā negativā rezultāta uzzināšanas (Wall et al., 2010; Oscarsson, Benzein, \& Wijma, 2008). Vidzemē veiktajā pētijumā konstatēts, ka bailes no izmeklējuma ir saistìtas ar ārsta apmeklējumu - sievietes, kurām nav bail no izmeklējuma, biežāk veic dzemdes kakla vēža skrīningu (Stupele, 2012). Intervijās sievietes stāsta, ka viṇām ir bail no iespējas atklāt vēzi, lai gan viṇas saprot, ka agrīna diagnostika var palīdzēt. Tāpat nepatīkams esot pats ārsta apmeklējums un izmeklējums. Vēl viens būtisks faktors ir laika trūkums (Park et al., 2011). Arì pašas sievietes to min kā skaidrojumu, piemēram, intervijās bieži attaisnojas, ka aizṇemtības dēḷ neizmanto uzaicinājumu veikt skrīningu. Vidzemē veiktajā pētijumā sievietes, kuras uzskata, ka vinām trūkst laika, retāk veikušas skrīningu. Gan pētījumos (piemēram, Park et al., 2011), gan intervijās 
minēts, ka brīvdienas pieškiršana darbavietā varētu veicināt ārsta apmeklējumu. Tomēr ne vienmēr šo faktoru vajadzētu uztvert kā reālu laika trūkumu. Profilaktiskās pārbaudes atlikšana var būt saistīta arī ar prokrastināciju, neprasm plānot laiku, nākotnes ieguvumu diskontēšanu u. c. skaidrojumiem, kas saistīti ar individa uzvedỉbu. Intervijās sievietes stāsta, ka nereti uzreiz neizmanto iespēju veikt profilaktisku skrīninga izmeklējumu, noliek uzaicinājuma vēstuli malā un vēlāk par to aizmirst.

Analizējot sieviešu viedokli par vēstules tekstu un tā uztveramỉbu, kā arì izmantojot iepriekš veikto pētijumu atzinas, iezīmējas vairāki apsvērumi, ko vajadzētu nemt vērā atbildīgajām institūcijām. Aptaujā 76,4\% sieviešu norādijjušas, ka uzaicinājuma vēstule bijusi pilnībā saprotama. Intervijās bija iespēja vairāk uzzināt par to, kā sievietes uztvērušas vēstuli un tās tekstu. Lai arī teksts ir saprotams, tomēr sievietes norādijja, ka tas ir formāls. Vēstules garums ir piemērots ${ }^{2}$, lai arī dažas sievietes uzsvērušas, ka tas ir pārāk garš. Pētijjumos norādīts, ka tam nevajadzētu pārsniegt vienu lappusi (Nathoo, 1988). Intervijās arī tika minēts, ka vairāk vajadzētu izcelt to, ka šis izmeklējums ir valsts finansēts ${ }^{3}$. Sievietes pozitivi vērtē to, ka vēstulē minētas tuvākās veselïbas aprūpes pakalpojuma vietas. Vidzemes aptaujā $66,4 \%$ sieviešu atzina, ka tad, ja vēstulē tiktu norādīts konkrēts laiks un vieta, kur un kad jāierodas, tas veicinātu viņas doties uz dzemdes kakla vēža skrīninga izmeklējumu (Stupele, 2012). Tas saskan ar vienu no iespējamiem pavirzī̌sanas risinājumiem - noklusējumu.

Valstīs, kurās ir plaši pārstāvēta kāda nacionālā minoritāte, uzaicinājuma vēstulēm vajadzētu būt divās valodās (Kivistik et al., 2011). Uz šo aspektu norādīja arī dažas intervētās sievietes, proti, dala sieviešu, iespējams, neizmanto skrīninga iespēju, jo nesaprot vēstules tekstu. Nacionālās veselības dienesta vēstulē ir saite uz vēstules tekstu krievu valodā, kā arì dienesta mājaslapā krievu valodā ir pieejama informācija par vēža savlaicīgas atklāšanas programmu.

\section{Risinājum}

Izvērtējot iepriekš sniegto informāciju un pavirzišanas teorētiskos aspektus, ir iespējami vairāki risinājumi, ko tālāk vajadzētu pārbaudīt eksperimentāli. Pirmkārt, atkārtoti un papildu atgóădinājumi. Tie kā risinājumi minēti gan intervijās, gan pētījumos (Camilloni et al., 2013). Tas varētu būt gan atkārtots atgādinājums pa pastu, gan atgādinājums pa telefonu, gan arì atgādinājums klātienē, ğimenes ārsta vizìtes laikā. Iespējami arì mūsdienīgāki risinājumi, piemēram, lietotnes izveide, kas palīdz ǵimenes ārstiem atgādināt saviem pacientiem par profilaktiskām pārbaudēm (ğimenes ārstam ir pieejama informācija par to, vai viṇa pacienti ir izmantojuši skrīninga iespēju).

Otrkārt, sociālās normas. Šo pieeju iespējams ìstenot divējādi. Pirmkārt, medijos vairāk stāstīt par citu sieviešu pieredzi. To kā būtisku risinājumu skrīninga veikšanai uzsvēra arī sievietes, intervijās stāstot, ka pievērš uzmanību šādiem stāstiem gan par pozitīvo, gan negatīvo pieredzi, piemēram, sieviete nav izmantojusi skrīningu un vēzis diagnosticēts novēloti, vai arī vēzis diagnosticēts agrīni un sieviete ir sekmīgi izārstēta. Otrkārt, sociālās normas iespējams iekḷaut vēstules tekstā, rakstot par skrīninga veikšanas statistiku, piemēram, «ceturtā dạa sieviešu ir izmantojušas vēža savlaicigas atklāšanas programmu» u.tml., tomēr šis risinājums pagaidām nav piemērots zemā apmeklējuma līmeṇa dēl

Treškārt, noklusējums. Tas nozīmē, ka vēstulē varētu iekḷaut konkrētu vietu un apmeklējuma laiku, kad sieviete var ierasties uz pārbaudi. Ar aptaujātās sievietes uzskata, ka šāda pieeja varētu veicināt ārsta apmeklēšanu. Protams, šādā gadijjumā jāparedz viegla un vienkārša iespēja atteikties no apmeklējuma, zvanot vai rakstot un atceḷot izmeklējumu. Šì pieeja varētu būt piemērota krūts vēža skrīningam - mamogrāfijas izmeklējuma veikšanai.

Ceturtkārt, ǵimenes ārsts kā autoritāte un persona, kas sniedz informāciju par vēža skrīningu. Ģimenes ārsta loma gan pētijumos, gan intervijās ir ippaši uzsvērta, piemēram, vēstules skaidrošanā un pamudināšanā to izmantot. Jau tagad normativie un veselïbas politikas dokumenti (Ministru kabinets, 2014) paredz palielināt ǵimenes ārsta atbildìbu attiecībā uz veiktajiem skrīninga pasākumiem praksē reǵistrētiem pacientiem. Viens no pavirzišanas veidiem ir arī ekonomiski stimuli - «lai veicinātu savlaicīgu laundabīgo audzēju diagnostiku un mazinātu mirstības gadijumu skaitu, no 2013. gada par katru savlaicīgi atklātu vēzi 1. vai 2. stadijā ǵimenes ārsts saṇem papildu maksājumu 71,14 euro apmērā» (Ministru kabinets, 2013). Tomēr no ètisko apsvērumu puses ir jāapzinās, ka stimuli var kaitēt ārsta un pacienta attiecībām, pat ja tie tiek lietoti godīgi. Tāpēc ieteikts naudas vietā labāk izmanto citus stimulus (Schmidt, Voigt, \& Wikler, 2010). Ārstam nevajadzētu sanemt papildu ekonomisko stimulu, ja pacients par savu veselỉbu, tās uzlabošanu un profilaksi rūpējas pats. Dažos gadījumos pacienti naudas stimulu ārstam varētu uztvert kā netaisnīgu, ja ārsts nav izrādījis interesi par pacientu, nav organizējis profilaktiskas vizites un izmeklējumus un ja pacients pats ir vērsies pie ārsta ar sūdzībām.

Piektkārt, emocijas (bailes). Lai mazinātu bailes no vēža un skrīninga izmeklējuma, būtu jāuzsver un jāveicina citas izjūtas, piemēram, lepnums, ka cilvēks rūpējas par sevi. Tāpat daudz vairāk būtu jāinformē par to, ka agrīni diagnosticēts vēzis lielā daḷā gadījumu ir ārstējams un nenozìmē tūlītēju nāvi.

Sestkārt, nākotnes ieguvumu diskontēšana. Tā kā sievietes bieži aizbildinās ar laika trūkumu un atliek pieteikšanos izmeklējumam, varētu 
izmantot gan jau iepriekš minēto noklusējumu, vēstulē ieklaujot konkrētu izmeklējuma laiku, gan akcentēt tūlìtējos ieguvumus, ja viņas izmantos iespēju veikt izmeklējumu, piemēram, jutîsies mierīgāk par savu veselību vai arì agrīni atklāto vēzi būs iespējams novērst.

Minētajos priekšlikumos netika iekḷauti risinājumi, kas attiecas, pirmkārt, uz sabiedrības informēšanu un izglìtošanu, otrkārt, ar veselības aprūpes pakalpojumu pieejamību saistīti risinājumi, piemēram, pakalpojuma pieejamība sievietēm laukos, treškārt, sociālo problēmu risinājumi. Uzmanības fokusā ir tie aspekti, kurus iespējams risināt ar pavirzī̌sanas palīdzību, jo bieži vien skrīninga neizmantošanas iemesli ir dziḷāki, piemēram, grūtības saplānot laiku.

Rakstā veiktajai analīzei ir vairāki ierobežojumi. Pirmkārt, analīze tika sašaurināta un veikta tikai par dzemdes kakla vēža skrīningu; otrkārt, sieviešu viedokla analizzei par ietekmējošiem faktoriem izmantots tikai vienā Latvijas reğionā veikts pētỉjums $(n=548)$; visbeidzot, jānem vērā pavirzišanas kritika. Tomēr var secināt, ka ir vairāki risinājumi, kas varētu veicināt un palielināt sieviešu dalību vēža savlaicīgas atklāšanas programmā (dzemdes kakla vēža skrinningā). Šos risinājumus plānots eksperimentāli pārbaudìt pētijumā, pavirzišanas paṇēmienu izvēlē un izveidē respektējot ētiskos apsvērumus. Pavirzišana var būt piemērots situācijas risinājuma veids, un par to liecina veiktā analīze un piedāvātie risinājumi.

\section{Izmantotie avoti}

The Behavioural Insights Team. Retrieved from http://www.behaviouralinsights.co.uk Blumenthal-Barby, J.S., \& Burroughs, H. (2012). Seeking better health care outcomes: The ethics of using the «nudge». The American Journal of Bioethics, 12(2), pp.1-10.

Camilloni, L., Ferroni, E., Cendales, B.J., Pezzarossi, A., Furnari, G., Borgia, P., Guasticchi, G., \& Rossi, P. G. (2013). Methods to increase participation in organised screening programs: a systematic review. BMC Public Health, 13: 464, pp.1-16.

Dolan, P., Hallsworth, M., Halpern, D., King, D., \& Vlaev, I. (2010). Mindspace: Influencing behavior through public policy. UK Cabinet Office \& Institute for Government.

European Council (2003). Council Recommendation 2 December 2003 on cancer screening. Official Journal of the European Union, 2003/878/EC

Frederick, S., \& Loewenstein, G. (2002). Time discounting and time preference: A critical review. Journal of Economic Literature, 40(2), pp. 351-401.

Hansen, P. G. (2014). Nudge and libertarian paternalism:Does the hand fit the glove? Copenhagen, Roskilde University, p. 23.
Hansen, P. G., \& Jespersen, A. M. (2013). Nudge and the manipulation of choice. A framework for the responsible use of the nudge approach to behaviour change in public policy. European Journal of Risk Regulation, 1, pp. 3-28.

Hausmann, D. M., \& Welch, B. (2010). Debate: To nudge or not to nudge. The Journal of Political Philosophy, 18(1), pp.123-136.

Johnson, E.J., \& Goldstein D. (2003). Do defaults save lives? Science, 302, pp.1338-1339.

Kahneman, D. (2003). Maps of bounded rationality: Psychology for behavioral economics. The American Economic Review, 93(5), pp. 1449-1475.

Kahneman, D. (2011). Thinking, Fast and Slow. Farrar, Straus and Giroux.

Kivistik, A., Lang, K., Baili, P., Anttila, A., \& Veerus, P. (2011). Women's knowledge about cervical cancer risk factors, screening, and reasons for nonparticipation in cervical cancer screening programme in Estonia. $B M C$ Woman's Health, 11, pp. 1-6.

Ministru kabinets (2013, 30. dec.). MK noteikumi Nr.1529 «Veselïbas aprūpes organizēšanas un finansēšanas kārtiba». Pieṇemts 17.12.2013. Latvijas Vēstnesis, 253.

Ministru kabinets (2014, 17. okt.). MK rikojums Nr. 589 «Par Sabiedrïbas veselïbas pamatnostādnēm 2014.-2020. gadam». Pienememts 14.10.2014. Latvijas Vêstnesis, 206.

Li, M., \& Chapman, G. B. (2013). Nudge to health: Harnessing decision research to promote health behavior. Social and Personality Psychology Compass, 7(3), pp. 187-198.

Lipkus, I., Klein, W., Skinner, C. S., \& Rimer, B. (2005). Breast cancer risk perception and breast cancer worry: What predicts what? Journal of Risk Research, 8(5), pp. 439-452.

Mont, O., Lehner, M., \& Heiskanen, E. (2014). Nudging. A tool for sustainable behaviour? Report 6643. The Swedish Environmental Protection Agency.

Nacionālais veselības dienests (2016). Věža savlaicīgas atklāšanas programmas rezultāti. Izgūts no http://www.vmnvd.gov.lv/lv/veselibas-aprupespakalpojumi/veza-savlaicigas-atklasanas-programma/programmas-rezultat

Nathoo, Y. (1988). Investigation of non-responders at a cervical cancer screening clinic in Manchester. British Medical Journal, 296, pp.1041-1042.

O’Keefe, D.J., \& Jensen, J.D. (2009). The relative persuasiveness of gain-framed and loss-framed messages for encouraging disease detection behaviors: A metaanalytic review. Journal of Communication, 59(2), pp. 296-316.

Oscarsson, M., Benzein, E., \& Wijma, B. (2008). Reasons for non-attendance at cervical screening as reported by non-attendees in Sweden. Journal of Psychosomatic Obstetrics \& Gynecology, 29, pp. 23-31.

Park, M.J., Park, E., Choi, K., Jun, K.J., \& Lee, H. (2011). Sociodemographic gradients in breast and cervical cancer screening in Korea: the Korean National Cancer Screening Survey (KNCSS) 2005-2009. BMC Cancer, 11, pp.1-8. 
Purnell, J.Q., Thompson, T., Kreuter, M.W., \& McBride, T.D. (2015). Behavioral Economics: «Nudging» undeserved populations to be screened for cancer. Preventing Chronic Disease, 12(1), pp.1-9.

Schmidt, H., Voigt, K., \& Wikler, D. (2010). Carrots, sticks, and health care reform Problems with wellness incentives. New England Journal of Medicine, 362:e3.

Slimïbu kontroles un profilakses centrs (2015a). Statistikas dati par iedzivotāju mirstibu. Izgūts no http://www.spkc.gov.lv/veselibas-aprupes-statistika/

Slimïbu kontroles un profilakses centrs (2015b). Onkoloǵija. Statistikas dati par pacientu skaitu sadalijumā pa reǵioniem, lokalizācijas veidiem, dzimuma un vecuma grupām no 2010. gada lïdz 2014. gadam. Izgūts no http://www.spkc. gov.lv/veselibas-aprupes-statistika/

Slovic, P., Finucane, M., Peters, E., \& MacGregor, D. (2002). The affect heuristic. In T. Gilovich, D. Griffin, \& D. Kahneman (Eds.), Heuristics and biases: the psychology of intuitive thought (pp.397-420). New York: Cambridge University Press.

Social and Behavioral Sciences Team. Retrieved from https://sbst.gov/ Stupele, L. (2012). Dzemdes kakla vēža savlaicīgas atkläšanas programmas (skrīninga) apmeklētìbas ietekmējošie faktori Vidzemes reğionā (bakalaura darbs). Vidzemes Augstskola.

Sunstein, C. R. (2014). Nudging: A very short guide. Journal of Consumer Policy, 37(4), pp. 583-588.

Thaler, R.H., \& Sunstein, C.R. (2008). Nudge: Improving decisions about health, wealth and happiness. Yale University Press.

Wall, K., Rocha, G., Salinas-Martınez, A., Baraniuk, S., \& Day, S. (2010). Modifiable Barriers to Cervical Cancer Screening Adherence among Working Women in Mexico. Journal of Women's Health, 19, pp. 1263-1270.

Wardle, J., Robb, K., Vernon, S., \& Waller, J. (2015). Screening for prevention and early diagnosis of cancer. American Psychologist, 70(2), pp.119-133. 


\section{Bibliotekāra kā mediatora loma

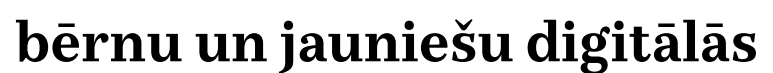 \\ pratības veicināšanā}

Attīstoties informācijas un komunikācijas tehnoloğijām, rodas jaunas iespējas un arī riski informācijas pārraidē un informācijas izmantošanā. Bērni un jaunieši ir minami starp aktīvākajām sabiedrības grupām tehnoloǵiju un interneta lietošanā. Saskaṇā ar informāciju statistisko datu krājumā «Bērni Latvijā» (Centrālā Statistikas pārvalde, 2016) jau 2015. gadā internets Latvijā bija pieejams 94\% mājsaimniecību, kurās ir bērni, $92 \%$ jauniešu 15 gadu vecumā lietoja sociālos tìklus, bet $83 \%$ lietoja internetu telefonā. Kā redzams - jaunā paaudze loti bieži un intensivi uzturas digitālajā vidē, izmantojot atšḳirīgas interneta platformas dažādās vietās. Tajā pašā laikā EU Kids Online pētỉjuma rezultāti liecina: kaut arī bērni un jaunieši prot brīvi lietot dažādas ierīces (datorus, planšetdatorus, viedtālrunus u.c.), vinu prasmes novērtēt informācijas resursu kvalitāti nereti nav augstas, kā arī bieži vien bērni neapzinās, kādi riski pastāv viṇu darbībai interneta vietnēs un kādas var būt šīs darbïbas sekas (Brikse \& Spurava, 2014). Tikmēr paši bērni Latvijā ir salīdzinoši augstās domās par savām prasmēm rīkoties digitālajā vidē un bieži attīsta savas stratēǵijas, kā apgūt jaunas digitālās prasmes un arī kā rast risinājumus potenciālām problēmām. Rodas jautājums, vai šìs pašradìtās stratēǵijas vienmēr ir bērniem atbilstošākās (Brikse, Freibergss, \& Spurava, 2014).

Šādā situācijā viens no sabiedrības uzdevumiem būtu informācijpratības, un īpaši digitālās pratības, pilnveidošana bērnu un jauniešu vecumgrupā, pirmkārt, izmantojot tradicionālo sociālo mediatoru - vecāku un pedagogu - palīdzību. Diemžēl vecāku gatavìba un interese veicināt bērnu digitālo pratību ir salīdzinoši zema. Ne vecāki, ne pedagogi Latvijā bērniem un jauniešiem nav autoritātes digitālās pratības jomā, bērni ir neatkarīgi savās attieksmēs pret digitālo vidi, un paḷaušanās uz vecāku vai pedagogu padomiem ir minimāla (Brikse et al., 2014).

EU Kids Online pētījuma dati liecina arī par to, ka Latvijā ievērojam vairāk nekā citviet Eiropā bērni un pusaudži lieto internetu bibliotēkāsLatvijā $46 \%$ bērnu vecumā no 9 līdz 16 gadiem atzinuši, ka lieto internetu bibliotēkās un citās publiskās vietās, kamēr vidēji Eiropā par šādu lietojumu ir norādījuši tikai $12 \%$. Pētijumā jautāti, vai vini ir sanēmuši padomus saistībā ar interneta lietojumu no bibliotekāriem, Latvijā vairāk nekā piektdala bērnu (21\%) atbildējuši apstiprinoši. Tas ir loti augsts rādītājs salïdzinājumā ar vidējo Eiropā, kur tikai $6 \%$ atbildējuši apstiprinoši uz šo jautājumu (Brikse \& Spurava, 2014)

Viens no galvenajiem iemesliem, kāpēc Latvijas publiskās bibliotēkas ir vieta, kurās bērni un jaunieši aktīvi izmanto internetu, ir tas, ka, pateicoties projekta «Trešais tēva dēls» istenošanai Latvijā, tajās ir nodrošināta piekḷuve internetam un atbilstoša datortehnika (Valsts ağentūra, 2008). Lab attīstītā publisko bibliotēku infrastruktūra Latvijā, līdzšinējais ieguldījums to nodrošinājumā ar informācijas tehnoloớijām, ilggadēja pieredze bibliotekāru 
apmācības organizēšanā rada bibliotēkās potenciāli labvēlīgu vidi, lai tās klūtu par lokāliem centriem digitālās pratības veicināšanai. N̦emot vērā bērnu un jauniešu aktīvo interneta lietošanu bibliotēkās, kā arỉ digitālās pratības mediācijas deficìtu no vecāku un pedagogu puses, būtiski ir noskaidrot, vai publisko bibliotēku bibliotekāri ir potenciāli gatavi pildìt sociālās lomas attiecībā uz bērnu un jauniešu digitālās pratības pilnveidošanu.

Tradicionāli viena no būtiskākajām bibliotekāru sociālajām lomām ir saistìta ar informācijpratības apguves nodrošināšanu. Šī raksta izklāsta pamatā ir pētỉjums, kura mērḳis ir iegūt informāciju, kas palīdzētu noskaidrot, vai bibliotekārs ir gatavs jaunai lomai, proti, būt par mediatoru bērnu un jauniešu digitālās pratības pilnveidošanai. Pētijumā izmantotas kvalitatīvās datu ieguves metodes: padziḷinātās, daḷeji strukturētās intervijas ar publisko bibliotēku bibliotekāriem un bibliotēkas nozares pārstāvju grupu diskusijas, kas veiktas laika posmā no 2015. gada oktobra lïdz 2017. gada jūnijam. Kā sekundārie dati analizēta 2013. gadā veikta bibliotekāru aptauja.

Raksta struktūru veido šādas tematiskās sadaḷas: 1) bibliotekāra jaunās lomas kā sociāla inovācija, 2) bibliotekārs kā digitālās pratîbas mediators, 3) pētỉjuma empīriskā materiāla analīze, 4) secinājumi.

\section{Bibliotekāra jaunās lomas}

kā sociālās inovācijas

Informācijas un komunikāciju tehnoloğiju (IKT) attīstības rezultātā jau ilgāku laiku sabiedrībā kopumā, kā arī profesionālajā vidē parādās diskusijas un pētnieciski raksti par bibliotekāra profesijas un bibliotēku atbilstību mūsdienu informācijas sabiedrības vajadzībām, par to nākotnes perspektīvām. Viedokḷus var iedalìt divās lielās grupās: 1) pesimisti, kas nākotni profesijai nesaredz vai arì to redz loti îsu; 2) optimisti, kas redz jaunas iespējas gan bibliotēku darbībai kopumā, gan bibliotekāra profesijas jaunajām iespējām: profesionālajām lomām un atbildībām.

2015. gadā grieķu zinātnieku veiktajā pētỉjumā, kura rezultāti apkopoti publikācijā (Vassilakaki \& Moniarou-Papaconstantinou, 2015), secināts, ka profesionāli, diskutējot par bibliotekāra uzdevumiem mūsdienu sabiedrībā, par galvenajām bibliotekāra lomām dažāda tipa bibliotēkās uzskata šãdas: bibliotekārs kā skolotājs; bibliotekārs kā tehnoloğiju speciālists; «iegultais (ieklautais) (embedded) bibliotekārs»; bibliotekārs kā informācijas konsultants; zināšanu menedžeris (pārvaldītājs); nozares bibliotekārs. Vienas no interesantākajām un tajā pašā laikā izaicinošākajām nākotnes bibliotekāra amatu prognozēm ir apskatītas rakstā «Bibliotekārs 2020» (The Librarian 2020) (Aldrich \& Keller, 2013). Raksta autori aplūko vairākas ar informāciju saistītas attīstibas tendences sabiedrībā: 1) informācija visur, 2) pieaugoša mobilo un iegulto (embeded) tehnoloǵiju lietošana, 3) sociālo zināšanu apjoma palielināšanās; 4) dzīves ilguma pagarināšanās un dzives stila dizaina izveide, 5) robotu

Tabula. Jaunie bibliotekāru amati un prasmes

$\begin{array}{lll}\text { Amats Atbildība Prasmes } & \end{array}$

«Iegultais

bibliotekārs»

Atbildīgs par visu priekšmetu kataloğizēšanu un pievienošanu globālajai smadzeņu bibliotēkai. Šis amats ir svarīgs, lai visi cilvēki varētu lietot iegultās tehnoloğijas, kas nodrošinātu piekḷuvi informācijai par visu visapkārt («lietu internets»).

noformēšanas

(satura

veidošanas

pakete)

bibliotekārs
Atbildīgs par dinamisku kontaktu uzturēšanu starp bibliotēku un kopienas informāciju tā, lai lietotāji var viegli atrast datus, kas atbilst noteiktam tematam un var novest pie citas nozìmīgas informācijas.

Strādāt atvērtā vidē, attālināti; strādāt virtuāli trīs dimensiju vidē, lietojot avatāru; efektīvi komunicēt, lai savāktu informāciju un attēlus; lietot jaunāko aparatūru un programmatūru, lai veidotu globālo smadzeṇu bibliotēku (Global Brain Library - GBL); ieviest jaunākos GBL kataloğizācijas un metadatu standartus; nodrošināt palīdzību tìkla un informācijas lie-

tošanai sabiedrībā; būt elastīgam un gatavam nepārtraukti mācīties.

Lietot visus analogās un digitālās informācijas formātus; efektīvi komunicèt ar visām iesaistìtajām/ieinteresētajām pusēm un iegūt atlauju izmantot informāciju; veidot dinamiskus kontaktus starp visa veida informāciju par konkrētu tematu; lietot jaunākos GBL kataloğizācijas un metadatu standartus; iegūt atgriezenisko saiti no lietotājiem, lai noteiktu, vai satura pakete ir pilniga; veidot un koordinēt satura noformēšanas brīvprātīgo darbinieku kopienu; būt elastiggam un gatavam nepārtraukti mācīties.

Robotu uzturēšanas

bibliotekārs
Atbildīgs, lai visi publiskās izmanto- Pārvaldīt pirmās paaudzes publiskās šanas un krājuma roboti atbilstoši darbotos. Publiskās izmantošanas robotiem ir jālieto jaunākā sintakse un 3-D hologrāfisko avatāru programmatūra, lai palīdzētu lietotājiem. Krājuma robotiem ir jābūt spējigiem atrast un izgūt materiālus, kas nepieciešami lietotājiem. izmantošanas un krājuma aparatūru un programmatūru; efektivi komunicēt ar darbiniekiem un lietotājiem; izstrādāt un novērtēt projektu plânus; pārvaldìt un apmācìt darbiniekus, kas strādā ar robotiem; būt elastīgam un gatavam nepārtraukt mācities. 


\begin{tabular}{|c|c|c|}
\hline Amats & Atbildība & Prasmes \\
\hline $\begin{array}{l}\text { Dzives stila } \\
\text { dizaina } \\
\text { bibliotekārs }\end{array}$ & $\begin{array}{l}\text { Atbildīgss par bibliotekāru koman- } \\
\text { das vadī̌nanu, vin̄i ir specializēju- } \\
\text { šies individuālā apkalpošanā, lai pa- } \\
\text { līdzētu mācǐšanās, karjeras mainas, } \\
\text { veselības u.c. specifiskās cilvēku } \\
\text { vajadzībās. Amats, kas nodrošina } \\
\text { cilvēcisku aspektu, lai palīdzētu } \\
\text { sasaistit cilvēku ar atbilstošu resur- } \\
\text { su, kurš nodrošinātu iespēju būt } \\
\text { veiksmīgam. }\end{array}$ & $\begin{array}{l}\text { Vadīt un iedvesmot dzīves stila dizai- } \\
\text { na personāla dinamisko komandu; } \\
\text { efektīvi komunicēt ar iesaistītajām } \\
\text { pusēm; radīt atbalstošu komunikā- } \\
\text { ciju ar lietotājiem; novērtēt pakalpo- } \\
\text { jumus un nodrošināt nepārtrauktu } \\
\text { pilnveidi; būt elastīgam un gatavam } \\
\text { nepārtraukti mācīties. }\end{array}$ \\
\hline $\begin{array}{l}\text { Globālo } \\
\text { smadzeņu } \\
\text { bibliotēkas } \\
\text { mākoṇ- } \\
\text { inženieris }\end{array}$ & $\begin{array}{l}\text { Atbildīgss par sistēmas prasībām } \\
\text { atbilstošu tīmekḷa pakalpojuma at- } \\
\text { tỉstỉbu, kas nodrošina globālo sma- } \\
\text { dzeṇu bibliotēkas saskarni ar citām } \\
\text { uz mākoṇiem bāzētām smadzeṇu } \\
\text { bibliotēkas krātuvēm pasaulē, pa- } \\
\text { lielinot sabiedrībai pieejamās infor- } \\
\text { mācijas kapacitāti un pieejamību. }\end{array}$ & $\begin{array}{l}\text { Izprast tīmekḷa pakalpojumus un } \\
\text { geokodēšanas standartus; demons- } \\
\text { trēt plašas zināšanas par GBL mākoṇ- } \\
\text { krājumiem; efektīvi komunicēt ar } \\
\text { visām iesaistitajām pusēm un iegūt } \\
\text { atbilstošas ațaujas informācijas iz- } \\
\text { mantošanai/lietošanai; lietot jaunā- } \\
\text { kos GBL kataloğizācijas un metadatu } \\
\text { standartus; būt elastīgam un gatavam } \\
\text { nepārtraukti mācīties. }\end{array}$ \\
\hline
\end{tabular}

(Aldrich \& Keller, 2013)

integrēšanās sabiedrībā. Atsaucoties uz šìm tendencēm, autori pamato jaunu darba amatu izveidošanos un attīstību bibliotēkās: «iegultais (iekḷautais) bibliotekārs» (embedded librarian), satura noformēšanas bibliotekārs (content packaging librarian), robotu uzturēšanas bibliotekārs (robotic maintenance engineer), dzīves stila dizaina bibliotekārs (lifestyle design librarian), globālo smadzeṇu bibliotēkas mākoṇinženieris (Global Brain Library cloud engineer). Šiem amatiem ir pievienots arī prasmju apraksts (sk. tabulu).

Kopumā var secināt, ka arī radikāli jaunajām bibliotekāra atbildībām jaunajos amatos ir nepieciešamas prasmes, par kurām profesionālajā sabiedrībā jau ilgāku laiku valda vienprātība: tās ir IKT lietošanas prasmes, resursu (informācijas un/vai personāla) pārvaldỉbas prasmes, kā ari efektīvas komunikācijas prasmes un nepārtrauktas mācīšanās prasmes. Tātad skatijums uz nākotnes bibliotekāru paredz, ka profesijas pārstāvji ir zinoši un prasmīgi jaunāko IKT lietotāji, resursu pārvaldītāji, kā arī dažādu informācijas lietotāju grupu apkalpotāiji.

Jaunos bibliotekāru amatus un lomas var uzskatīt par sociālām inovācijām, jo sociālās inovācijas attiecas uz jaunām sociālām praksēm, kas ietver jaunas idejas, jaunus modeḷus, jaunus noteikumus, jaunas sociālās attiecības, jaunus pakalpojumus un/vai jaunus produktus (Social Innovations, n. d.) Iepriekš aprakstìtie bibliotekāru amati ir jaunas prakses, kurās ietvertas jaunas idejas, noteikumi, modeḷi, sociālās attiecības un pakalpojumi, bet kuras veidojas, pamatojoties uz jau esošo resursu (piemēram, dạı zināšanu un prasmju) jaunu lietojumu. Savukārt jaunie amati un jaunās lomas bibliotekāriem radīs iespēju piedāvāt jaunus pakalpojumus. Atbilstoši jauninājumu vai izmaiṇu apjomam piedāvātajā pakalpojumā pakalpojums iespējams iedalīt trīs grupās: nedaudz uzlaboti iepriekšējie pakalpojumi, pārveidoti (evolucionārie) iepriekšējie pakalpojumi un pilnīgi jauni (revolucionāri) pakalpojumi, kuri pat spēj piesaistīt jaunas lietotāju grupas (IDEO, 2015).

\section{Bibliotekārs kā digitālās} pratības mediators

SOCIĀLĀ MEDIĀCIJA EU Kids Online pētỉjuma veicēji atzinuši (Livingstone, $n$. d.)

ka bērnu un jauniešu prasmju attīstīšanā vai neattīstīšanā nozīmịga vieta ir ierādāma mediatoriem. Mediatori ir sociālie ağenti (vecāki, skolotāji, brāli un māsas, klasesbiedri, draugi u.c.), kas spēj ietekmēt bērnu/jauniešu dzīvi vai, konkrētāk, rīcību un uzvedību.

Mediatoru loma galvenokārt tiek akcentēta saistībā ar pienākumu sniegt zināšanas par dažādiem riskiem internetā (piemēram, par agresīva, seksuāla rakstura informācijas ieguvi vai izplatišanu, par iebiedēšanu, par personisko datu izpaušanu un tā sekām, par neētisku informācijas avotu izmantošanu u.tml.) un prasmēm no šiem riskiem vai nu izvairīities, vai ar veiksmigi pārvarēt.

Teorētiskajā modelī par to, kā bērni un jaunieši izmanto internetu pētījumu veikšanai (Livingostone, n. d.), sociālās mediācijas aǵenti ir izcelti kā būtisks uzvedību ietekmējošs elements. Bērnu vecāki šajā modelī tiek uztverti kā nozīmigaākie pieaugušie sociālie mediatori. Vecāku mediācija digitālajā pratībā - gan no bērnu, gan vecāku perspektīvas, ir pētìta arī Latvijā. Analīze ir veikta, izmantojot $E U$ Kids Online pētijuma datus, un liecina, ka pastāv būtiska plaisa vecāku zināšanās par to, ar ko bērni nodarbojas digitālajā vidē, un to, kāda ir vinu bērnu patiesā dzìve internetā (Brikse et al., 2014).

N̦emot vērā, ka vecāku kapacitāte veicināt bērnu un pusaudžu digitālo pratību ir zema, citu pieaugušo - skolotāju un bibliotekāru - potenciālā loma digitālās pratības mediācijā kḷūst jo nozīmigaāka. Pētijumu, kuros tiktu aplūkoti skolotāji un bibliotekāri kā potenciālie digitālās pratības mediatori, ir salīdzinoši maz. Atsevišķas publikācijas par pedagogu lomu digitālās pratības mediācijā tapušas $E U$ Kids Online projektā (Kalmus, von Feilitzen, \& Siibak, 2012). Vienā no pētijjumiem aplūkots (Kalmus, 2013), ka sociālā 
mediācija bērnu interneta izmantošanā ir iedalāma divās kategorijās - sociālais atbalsts (t.i., palīdzība, vadīšana (guidance) un kopiga lietošana; kopiga interpretācija) un noteikumi un ierobežojumi (t.i., noteikumu un ierobežojumu apzināšanās un to nostādnes).

DIGITĀLĀ PRATīBA Lai bibliotekārs spētu būt par sociālo mediatoru, tam pašam nepieciešama laba digitālā pratība, tāpēc turpmāk sniegts iss digitālās pratības raksturojums kontekstā ar informācijpratỉbu un citām pratībām. Termins «pratība» (angl. literacy-rakstpratība) ir samērā jauns termins, kurš pirmo reizi lietots 19. gs. beigās, lai akcentētu dzivei nepieciešamās prasmes - cilvēka spējas uztvert un apstrādāt tekstu. Vēlāk tas papildinās ar rakstišanas prasmēm, pēc tam - ar prasmēm dažādās jomās, piemēram, matemātikā, datoru lietošanā u.tml. (Stordy, 2015).

Jebkura termina parādišanās ir cieši saistìta ar norisēm sabiedrībā un nepieciešamỉbu kādus jaunus jēdzienus fiksēt ar valodas zīmju sistēmas palīdzību, lai nodrošinātu gan izziṇas procesus, gan komunikāciju. Šefīldas Universitātes pētnieks Pīters Stordijs (Peter Stordy) (2015) rakstā «Pratību taksonomija» (Taxonomy of literacies) norāda, ka profesionālajā literatūrā sastopami vismaz 35 dažādi pratību apzīmējumi ar atšḳirīgu vispārinājuma pakāpi, kur katrs akcentē kādu īpašu prasmju aspektu (piemēram, transpratìba vai metapratība - kā loti apkopojoši prasmju apzīmētāji; datorpratība vai tīklpratība - kā konkrētu prasmju apzīmētāji).

Pamatojoties uz literatūras pētỉjumiem, visvairāk lietotās pratības tekstos ir informācijpratība un digitālā pratība (Stordy, 2015). Tās var tikt uzskatìtas gan par kognitīvām spējām, gan sociālo praksi. Informācijpratība kā termins ieviests 1974. gadā, un tā izcelsme ir saistīta ar informācijas atrašanu bibliotēkās; mūsdienās informācijpratība ir būtiski atkarīga no prasmēm arī lietot dažādus e-resursus (katalogus, datubāzes, e-grāmatas, interneta resursus u.c.), tādējādi to satuvinot ar digitālo pratību un tajā pašā laikā arī paplašinot informācijpratības jēdziena aptvērumu, to pakāpeniski papildinot arì ar tādu informācijas resursu prasmìgu lietošanu, kas atrodami ārpus bibliotēkām (piemēram, pieejami internetā no jebkuras vietas un jebkurā laikā). Dažādās informācijpratības izpratnes iespējams klasificēt trīs veidos: 1) informācijpratība kā informācijas laikmetam nepieciešamo prasmju apguve; 2) informācijpratība kā prāta ieradumu kultivēšana (kognitīvas prasmes); 3) informācijpratība kā iekḷaušanās nosacỉjums ar informāciju bagātās sociālās praksēs (Addison \& Meyers, 2013).

P.H. Stordijs (2015) arī atzīmē, ka bieži vien termini «informācijpratība» un «digitālā pratība» lietoti kā savstarpēji aizvietojoši, gan izceḷot, ka informācijpratība ir aptverošāks termins, kurš ietver digitālo pratību, gan arī pretēji-norādot, ka digitālā pratība ir plašāks jēdziens, kurš ietver arī informācijpratību (piemēram, JISC, 2014).
Pamatojoties uz UNESCO pienemto skaidrojumu, informācijpratība tiek definēta kā kompetenču kopums, kas «dod iespēju iedzīvotājiem piekḷūt, iegūt, saprast, novērtēt un izmantot, kā arī radīt un apmainīties ar informāciju un mediju saturu visos formātos, izmantojot dažādus instrumentus, kritiskā, ètiskā un efektīvā veidā, lai piedalītos un iesaistītos personiskajā, profesionālajā un sabiedriskajā darbībā» (UNESCO, 2013, p. 29). Informācijpratības kompetences tiek iedalītas trīs grupās: piekḷuve, novērtēšana un radīšana, un tās iekḷauj arī digitālo mediju lietošanu.

Pirmo reizi termins «digitālā pratība» lietots 1997. gadā, to ieviesis rakstnieks un skolotājs Pauls Gilsters (Paul Gilster) (1999). Viņš to skaidrojis samērā vispārīgi - kā spējas saprast un lietot informāciju no dažādiem digitāliem avotiem/resursiem, un digitālo pratîbu uzskatija par galveno pratību digitālajā laikmetā. Līdzīgi termini šim ir «multimedijpratība», «sociālo mediju pratība», «digitālo mediju pratība», «internetpratība». Šie termini akcentē mediju satura kritisku novērtēšanu un lietošanu, taču ir arī termini, kuros akcentētas prasmes lietot tehnoloǵijas (piemēram, «datorpratība», «IKT pratība»). Arī Eiropas Komisijas digitālās pratības skaidrojumā 2007. gadā (European Comission, 2007) bijusi uzsvērta IKT prasmigga (confident) un kritiska lietošana darbam, brīvajā laikā, mācībām un komunicēšanā. Starptautiskā Bibliotēku un informācijas asociāciju federācija (IF LA) savā vietnē ar norāda, ka digitālā pratība ir jēdziens, kurš ietver gan tehniskās prasmes, gan arī vairākas netehniskas prasmes (piemēram, saziṇas prasmes, ētikas un tiesību zināšanas, noteiktus uzvedības standartus), un ka tā ir cieši saistīta un pārklājas ar informācijpratību un medijpratību (IF LA Statement on Digital Literacy, 2017). Digitālās pratības operacionalizēšanai noderīgāki ir skaidrojumi, kuros redzamas konkrētas prasmes. Tā, piemēram, Apvienotajā Karalistē ir izstrādātas programmas, kuru mērķis ir palīdzēt iedzivotājiem attīstī pamata digitālās prasmes, tās uzskatot par tikpat būtiskām valsts iedzīvotāju prasmēm kā rakstpratība un skaitḷpratība (numeracy). Digitālā pratība tiek iedalīta piecās prasmju grupās: informācijas pārvaldỉba, komunicēšana, transakciju veikšana, radišana un problēmrisināšana (MORI, 2015).

NOZĪMİGĀKĀS DIGITĀLĀS PRASMES IR ŠĀDAS (MORI, 2015):

1) informācijas pārvaldības jom $\bar{a}$-meklēt (piemēram, lietot atbilstošu meklētājprogrammu informācijas atrašanai), pārvaldīt un saglabāt digitālo informāciju (piemēram, lietot grāmatzīmju iespēju resursu saglabāšanai, prasmes saglabāt datus atminnas ierīcēs un mākonnos). Tās ietver arī prasmes, kas saistitas ar drošību: novērtēt informācijas avota precizitāti, lietot drošus rīkus informācijas pārlūkošanai, regulāri lietot un atjaunot datorvìrusu programmatūru un kā vecākiem kontrolèt bērnu darbošanos internetā; 
2) komunicēšanas jomāa-pārraidīt, dalīties, sadarboties ar citiem (piemēram, lietot e-pastu, ziṇu apmaiṇas iespējas, video zvanus, sociālos medijus, publicēt ziņas forumos, sazināties ar organizācijām par vinu produktiem un pakalpojumiem). Attiecībā uz drošību: saprast, kā pārvaldīt savas identitātes, aizsargāt savus personas datus, aizsargāt sevi no krāpniecỉbas, lietot pareizos drošibas iestatījumus;

3) transakciju jomā-pirkt un pārdot preces un pakalpojumus, organizēt savas finanses un lietot digitālās e-pārvaldes iespējas (pakalpojumus) (piemēram, saprast, kur var iepirkties, pasūtît pirkumu, rezervēt ceḷojumu, pārvaldīt bankas kontu u.c.). Attiecībā uz drošību - lietot finanšu transakcijām drošas tīmekḷa vietnes, aizsargāt savus personiskos datus, respektēt citu privātumu;

4) problēmrisināšanas jomā - palielināt neatkarību un pārliecību, atrisinot problēmas un atrodot risinājumus ar digitālajiem rīkiem (piemēram, iemācīties veikt vienkāršus uzdevumus, izmantojot mācību materiālus/instrukcijas; iegūt atgriezenisko saiti no citiem interneta lietotājiem, lai risinātu kopīgās problēmas; piekḷūt atbalsta pakalpojumiem (dienestiem) un izmantot tos). Attiecībā uz drošību: lietot zināmus/drošus atbalsta avotus, izvairīties no krāpniecības, launprātīgām vietnēm, uznirstošiem logiem;

5) radī̌anas jomā-radīt jaunu digitālu saturu, lai iesaistitos digitālās kopienās un organizācijās (piemēram, radīt ziṇojumu sociālos medijos; radīt teksta dokumentu (piemēram, cv); radīt fotogrāifjas un dalīties ar tām; radìt atgriezenisko saiti par produktiem un pakalpojumiem un dalīties ar to). Attiecībā uz drošǐbu nepieciešamas zināšanas par autortiesībām, personisko datu aizsardzību, citu privātuma respektēšanu.

Arī resursos, kas aplūko vecāku lomu bērnu digitālo prasmju attīstī̌anai, ir uzskaitītas līdzịgas digitālās prasmes, kas sagrupētas nedaudz atšķirīgās prasmju grupās: 1) pamata digitālās prasmes (tās ietver privātuma, satura un tehnoloğiju pārvaldību), 2) komunikācijas prasmes (ietver komunikācijas mijiedarbības prasmes, sociālo un emocionālo regulāciju), 3) radošums (ietver radošuma un problēmrisināšanas prasmes, pašregulācijas prasmes), 4) mūžizglìtošanās prasmes (ietver informācijas meklēšanas, novērtēšanas prasmes, tehnoloğiju lietošanas prasmes) (Romero, 2014). Šo prasmju kopums veido arī digitālo inteliǵenci (Digital intelligence, n. d.), kuras attīstīšana bērnos ir pieaugušo pienākums (Park, 2016).
DIGITĀLĀS PRATĪBAS MEDIĀCIJA Visciešāk bibliotekāra kā mediatora loma digitālajā pratībā ir saistìta ar bibliotekāra kā skolotāja un bibliotekāra kā tehnoloğiju speciālista lomu. Lìdz šim bibliotekārs kā skolotājs galvenokārt ir darbojies informācijpratības apmācībā. Mediācija digitālās pratības jomā prasìtu galvenos akcentus vērst uz zināšanām un prasmēm par digitālo vidi, kas ir strauji mainiga un prasa jaunu prasmju nemitīgu apguvi. Pieredze rāda, ka bibliotekāri ir prasmīgi informācijas meklēšanas un informācijas resursu novērtēšanas jautājumos. Ne velti saistībā ar veselības informācijas ieguvi, kā arī ar bibliotēku attīstību ir pat ieviests termins «apomediators» (Kwanya, Stilwell, \& Underwood, 2012), kas norāda, ka bibliotekārs var būt par gidu celā uz drošiem, kvalitatīviem informācijas avotiem. Pieškirot arvien lielāku lomu digitālo prasmju attīstībai sabiedrībā, arī bibliotēkām tiek īpaš akcentēts uzdevums nodrošināt digitālās pratības apguvi un tās veicināšanu visu tipu bibliotēkās. Par šĩ uzdevuma svarīgumu liecina arī 2017.gada 18. augustā publicētais IFLA ziṇojums par digitālo pratību (IFLA Statement on Digital Literacy, 2017).

Bibliotekāram kā digitālās pratības mediatoram būtu jāveic divi uzdevumi: 1) jāsniedz konsultatīvā palīdzība (vai apmācība) visās iepriekš minētajās piecās digitālās pratības jomās bērnam/jaunietim; 2) apzinoties dažādus ierobežojumus interneta izmantošanā, jākontrolē un jāizstrādā noteikumi, lai mazinātu riskus, ar kuriem bērns/jaunietis var sastapties internetā.

\section{Bibilotekārs kā digitālās pratîbas mediators Latvijas bibliotēkās}

Latvijā padzilināta izpēte par bibliotekāru atbilstību digitālās pratîbas mediatoru lomai un gatavibu uznemties ar to saistītos pienākumus lỉdz šim nav veikta. In-

formācijas deficīts šajā jomā noteica pētijuma mērki-iegūt informāciju, kas palīdzētu noskaidrot, vai bibliotekārs var būt par digitālās pratības mediatoru publiskajā bibliotēkā. Lai sasniegtu mērḳi, pētijumā tika izvirzīti šādi pētnieciskie jautājumi: 1) kāda ir pašu bibliotekāru digitālā kompetence, vai zināšanas par digitālo vidi un tehnoloğiskās prasmes ir pietiekamas, lai pildìtu digitālās pratības mediatoru lomu; 2) kāds ir bibliotekāru pašvērtējums un nozares pārstāvju redzējums par bibliotekāru iespējām un gatavibu pildī digitālās pratības mediatoru lomu un kādas galvenās funkcijas šajā kontekstā tiek saskatîtas. Lai rastu atbildes uz izvirzìtajiem pētnieciskajiem jautājumiem, empīriskajā izpētē tika gan analizēti sekundāri dati, gan iegūti un analizēti primāri dati.

Sekundāro datu analīzē aplūkots uz kvantitatīvo metodoloğiju balstìts pētijums - valsts ağentūras «Kultūras informācijas sistēmas» uzdevumā pētijumu centra SKDS veikta Latvijas publisko bibliotēku bibliotekāru aptauja (Latvijas publiskās bibliotēkas, 2013). Aptauja veikta 2013. gadā, un tajā 
tika iegūti rezultāti par bibliotekāru (respondentu skaits - 1196) pašvērtējumu -zināšanām un prasmēm dažādās jomās, tai skaitā arī par informācijas tehnoloğiju izmantošanas prasmēm.

Primāro datu ieguve tika balstīta uz kvalitatīvo metodoloǵiju: laika posmā no 2015. gada oktobra līdz 2017. gada jūnijam tika veiktas padziḷnātās, daḷēji strukturētās intervijas ar publisko bibliotēku bibliotekāriem un bibliotēkas nozares pārstāvju fokusgrupu diskusijas. Kopumā pētijumā informāciju snieguši 36 informanti-bibliotekāri un ar bibliotēku nozari saistīti speciālisti. Šì raksta autores kvalitatīvajā izpētē pašas nodrošināja interviju veikšanu, diskusiju moderēšanu, sākotnējo datu apstrādi un analīzi. Iegūto kvalitatìvo datu analize tika veikta, balstoties uz respondentu izteikumu nozīmju analīzi. Izteikumi tika kodēti un kategorizēti atbilstoši pētijuma mērḳim, pētnieciskajiem jautājumiem, kā arī pētnieciskās problēmas konceptuālajai izpratnei.

Empīriskā materiāla izklāsts strukturēts divās dalāas atbilstoši definētajiem pētnieciskajiem jautājumiem: pirmkārt, analizēti sekundārie un primārie dati, kas ḷauj gūt priekšstatu par bibliotekāru digitālās kompetences atbilstību mediatora lomai; otrkārt, analizēti primārie dati-bibliotekāru un bibliotēku nozares pārstāvju viedokḷi par bibliotekāru iespējām un gatavību pildīt digitālās pratības mediatora lomu bērnu un jauniešu apmācībā.

BIBLIOTEKĀRU DIGITĀLĀS KOMPETENCES Lai novērtētu Latvijas bibliotekāru potenciālu būt par digitālās pratības mediatoriem, izmantoti iepriekš veiktu pētījumu dati. 2013. gadā notikušās bibliotekāru aptaujas rezultāti rāda, ka respondenti augistu vērtē savas prasmes kopumā lietot internetu (e-pasts, mājaslapu meklēšana, «sērfošana») (99\%) un datoru (ieslēgt, izslēgt, izdrukāt u.c.) (99\%) - atbildes «protu ḷti labi» un «drīzāk protu». Arī, detalizētāk raksturojot interneta lietošanas prasmes, augsts pašnovērtējums ir par interneta meklētāju ( $99 \%)$ izmantošanu, e-pasta vēstuḷu sūtišanu (99\%), vietējās pašvaldỉbas un valsts iestāžu informācijas atrašanu internetā ( $99 \%)$, tiešsaistes datubāzu izmantošanu (96\%). Bibliotekāri arī uzskatijjuši, ka prot novērst vispārīgās tehnoloğiskās problēmas (96\%) un ka var palīdzēt citiem apgūt pamatprasmes lietot datoru un internetu (91\%) un izmantot e-katalogu (98\%). Visbiežāk, vērtējot savas zināšanas un prasmes izmantot interneta resursus un rïkus, atbildi «manas zināšanas un prasmes ir pietiekamas, lai konsultētu un apmācītu citus cilvēkus» bibliotekāri atzīmēja uz jautājumu par izglìtības informāciju un pakalpojumiem (74\%), darba meklēšanu internetā $(74 \%)$ un ekonomiskajām aktivitātēm internetā (71\%). To, ka viṇu zināšanas ir pietiekamas, lai konsultētu un apmācìtu citus cilvēkus par kultūras un brīvā laika informācijas resursu izmantošanu, norādīja $54 \%$ bibliotekāru, $50 \%$ to norādỉja par elektronisko komunikāciju, $48 \%$ - par dažādu socializēšanās portālu izmantošanu, $44 \%$ - par e-pārvaldes pakalpojumiem, $44 \%$ - par e-veselības pakalpojumiem un ar veselību saistītas informācijas meklēšanu. Aptuveni $2 / 5$ atzīmēja, ka viṇu zināšanu pietiek, lai konsultētu citus lietotājus par digitālo kolekciju izmantošanu (40\%) un ar lauksaimniecību saistītas informācijas meklēšanu (37\%).

Vairāk nekā puse atzinīgi vērtējuši savas prasmes veikt telefonzvanus, izmantojot internetu (77\%), piedalīties interneta tērzētavās un diskusiju forumos (57\%), veidot un uzturēt bibliotēkas profilu bibliotēku portālā biblioteka.lv (53\%). Retāk respondenti atzina, ka prot izmantot datnu apmainas programmas (43\%). Savukārt viskritiskāk bibliotekāri vērtēja savas zināšanas mājaslapu/blogu veidošanā ( $27 \%$ to prot darìt, bet $57 \%$ neprot).

Dažās jomās bibliotekāri savas prasmes biežāk uzskatīja par nepietiekamām, piemēram, prasmes izmantot $w e b 2.0$ risinājumus (51\%). Visretāk bibliotekāri jutās pārliecināti par savām prasmēm izmantot video apmaiṇas programmas ( $20 \%$ spēj konsultēt šajā jautājumā; $29 \%$ zina, kas tas ir, bet nezina, kā to izmantot; $2 \%$ nezina, kas tas ir), veidot digitālās kolekcijas (10\% spēj konsultēt šajā jautājumā; $38 \%$ zina, kas tas ir, bet nezina, kā to izmantot; 3\% nezina, kas tas ir), izmantot attēlu apmaiņas programmas ( $8 \%$ spēj konsultēt šajā jautājumā; $42 \%$ zina, kas tas ir, bet nezina, kā to izmantot; $14 \%$ nezina, kas tas ir) un veidot blogus ( $7 \%$ spēj konsultēt šajā jautājumā; $47 \%$ zina, kas tas ir, bet nezina, kā to izmantot; $3 \%$ nezina, kas tas ir).

Novērtējot šì pētijuma rezultātus atbilstoši piecām digitālās pratības prasmju grupām -1) informācijas pārvaldība, 2) komunicēšana, 3) transakcijas, 4) problēmrisināšana, 5) radī̌ana-, redzama šāda situācija. Bibliotekāri augstāk vērtē savas informācijas pārvaldības prasmes, kas arī bijušas dominējošās bibliotekāru darba prasmes, tai skaitā informācijas avotu novērtēěanas prasmes. Tomēr arì informācijas pārvaldības prasmju grupā ir vājākas jomas, piemēram, video un attēlu apmaiṇas programmu lietošana. Salīdzinoši nedrošāki bibliotekāri jūtas komunicēšanas un radīšanas prasmēs, īpaši sociālo mediju, blogu (emuāru), mājaslapu radī̌nanas jomā. Tomēr jāatzīst, ka šī aptauja nesniedz pilnīgu priekšstatu par bibliotekāru digitālo pratību, piemēram, par tādiem jautājumiem kā personisko datu aizsardzība, autortiesību pārzināšana, prasmes veikt finanšu operācijas u. c. Tāpat arì digitālās vides straujās attīstības rezultātā nav aplūkoti dažādi sociālo mediju lietošanas aspekti.

Veicot uz kvalitatīvo metodoloǵiju balstītās intervijas ar bibliotekāriem un vadot diskusijas ar bibliotēku nozares pārstāvjiem, viens no uzdevumiem bija padziḷināti noskaidrot respondentu viedokḷus par pašu bibliotekāru digitālo kompetenci un tās atbilstỉbu potenciālai digitālā mediatora lomai. Analīzes rezultāti liecina, ka bibliotekāru pašvērtējums par digitālajām prasmēm ir atšķirīgs - augstāks pašvērtējums vērojams bibliotekāriem, kas strādā pilsētās, attiecīgi lauku reğionos bibliotekāri ar dažiem iznēmumiem ir kritiskāki. To apstiprina arī diskusijā dzirdētais: «Augsstāks līmenis ir novadu 
centru pilsētu bibliotēkās. Pagasta bibliotekāru Jūs ne tik loti bieži sastapsiet ar augstāku prasmju līmeni. Ir jau, protams, arī pagasta bibliotekāri gaismas nesēji, kas strādā ḷoti labā līmenī. Bet biežāk tādi ir reğionu centros.»

Lielākoties visi aptaujātie bibliotekāri un arī bibliotēku nozares pārstāvji atzīst, ka bērnu pieredze un prasmes attiecībā uz interneta un tehnolog̣iju lietojumu bieži ir pārākas par bibliotekāru prasmēm: «Bērni nāk jau ar zināšanām. Neatceros, ka viṇi man būtu ko jautājuši, bērni jau tagad ḷoti ātri saprot, ko darìt ar datoru. Bērni, kas nāk, jau lielākoties ir iemācījušies mājās. Kā smejies - tagad jau tie, kas sēž pamperos, saprot datoru labāk par mani»; «Diezgan lielā mērā ir mainijies uzsvars un lomas interneta, un jo īpaši tehnoloğiju, lietošanā, bērni bieži vien apmāca vecāko paaudzi.»

Viena no būtiskākajām problēmām attiecībā uz digitālās vides pārzināšanu un potenciāliem riskiem, domājot par bibliotekāriem kā bērnu digitālās pratības mediatoriem, ir saistīta ar bibliotekāru salīdzinoši vājajām zināšanām par datorspēlēm / spēlēm tiešsaistē un to darbības pamatprincipiem: «Nu jā-un spēles jau arī spēlē. Es viṇiem teicu, lai nemeklē pa visurieni. Šad tad jau es paskatos. Tās šaušanas spēles, ko vini tur spēlē, tās jau viṇi māk atrast. Es jau tik pārlieku labi to nesaprotu. Vini jau tajā spēlu zināa ir daudz gudrāki par mani.» Saskaṇā ar bibliotekāru teikto spēḷ spēlēšana, jo ipaši puišiem, ir visbiežāk veiktā aktivitāte internetā bibliotēkās, nereti tiek norādīts uz tendenci, ka bērni kḷust atkarīgi no spēlu spēlēšanas. Bibliotekāru atbildes liecina, ka bērnu un pusaudžu interese par šādām aktivitātēm ir augsta, bet tā disonē ar bibliotekāru salīdzinoši zemo izpratni par spēlēm tiešsaistē, kā arì bezpalīdzības sajūtu un mulsumu attiecỉbā uz savu potenciālo lomu uzraudzìt spēlēšanas aktivitātes: «Kādreiz vasarā atnāk puika un klapē to savu spēlīti trīs stundas, galvu nepacēlis. Es viṇam saku - beidz klapēt un ej mājās. Māte domā-puika bibliotēkā, viss kārtībā - ir pieskatīts. Bet, no otras puses - es domāju, ka vasarā cilvēks jau var iet ārā - saulìte spid, bet viņš sēž un klapē to spēlīti. Beigās es viṇam teicu - zini ko, tu te tagad tikai vienu stundu vari sēdēt. Es nezinu, vai tādas ir manas tiesības to teikt, bet es domāju, ka visu dienu jau nav šitā jāklapē. Tur jau var palikt par muļ̧̣i. Bet tur jau neko neizdarīs. Kam jau nu tās spēles interesēs, un dažs labs jau ir tāds pilnigi atkarīgs. Ko tur var izdarìt - es nezinu, tas jau tikai ies uz priekšu. Tagad ir tāds laikmets un tur jau neko nevarēs izdarìt... Tur jau nekas nemainīsies. Spēles jau te vini var raut valā, cik uziet. Tāds ir laikmets, tur neko nevar izdarìt. Mans viedoklis ir, ka tur jau nekas nemainīsies, ies tikai arvien un arvien.»

Runājot par digitālajām kompetencēm, bibliotekāru intervijās tiek uzsvērta tehnoloğisko prasmju celšanai paredzēto apmācību un kursu loma. Vienlaikus gan bibliotekāru intervijās, gan nozares pārstāvju diskusijā tiek norādìts, ka kursu un apmācību laikā apgūtās zināšanas tagad strauji noveco un, piemēram, «Trešā tēva dēla» projekta laikā apgūtās zināšanas vairs nav lietojamas, jo būtiski ir mainijjušãs gan tehnoloǵijas, gan datoru programmnodrošinājums. Diskusijā tika atzìts, ka pēcprojekta periodā nozīmīga loma bibliotekāru apmācỉbas nodrošināšanā ir bibliotēkas vadỉbai. «Publiskajām bibliotēkām bija loti daudzi kursi, visi gāja kursos, loti daudz kursos, un tad projekts («Trešā tēva dēla» projekts) beidzās, un tad iestājās tāda kā liela pauze. Tas varētu būt viens no diskomforta avotiem. Tagad jādomā bibliotekāram pašam vai arī tas ir atkarīgs no bibliotēkas vadỉbas - cik tā ir aktīva un cik loti lielā mērā tālākizglìtību nodrošina. Tur, kur nav tā bibliotēku vadība tik advancēta un spējigga piesaistīt lìdzekḷus, tur bibliotekārs paliek viens pats ar savu problēmu. Bibliotekāru apmācības tad arī beidzās, kad plašākā sabiedrībā parādijjās viedtālruni un planšetes.»

Lai spētu sniegt profesionālu atbalstu bērniem un jauniešiem digitālās pratības jomā, bibliotekāri joprojām ir gatavi mācīties, apgūt papildu zināšanas un to arī dara. Tomēr pirmām kārtām viniem ir nepieciešams saprast, kas ir tas, kas viniem jāzina: «Ja jau man kaut ko vajag - tad es iemācos. Mums jau ir daudzi kursi bijuši. Tad jau kaut ko iemācijja, bet tagad jau atkal ir aizmirsies. [..] Bet es jau saku, ka ir bērni, kas ir gudrāki par mani. Viniem ātrāk pielec. Bet man jau vajag zināt, ko man vajag. Jo tās interneta iespējas jau arī ir bezgalīgas. Es skatos, kā tur datorikịi ṇēmās, līdz tam jau man ir tālu. Es negribu par sevi teikt, ka es nesaprotu, man tīri labi pielec, bet man vajag zināt, ko man jāzina. Visu jau tu nekad nevarēsi zināt. Es tā negribu teikt, ka es visu zinu, ir jau, ko es nezinu. Bet to jau visu var noskaidrot. Uz katru jautājumu var atrast atbildi.»

Bibliotēku nozares pārstāvju diskusijā tika vairākkārt uzsvērts, ka savu pienākumu profesionālai pildīšanai bibliotekāram ir nepieciešams sekot līdzi jaunākajām tendencēm tehnolog̣iju attīstỉbā, norādot, ka bibliotekāram tas būtu jāuzliek par pienākumu: «Tāpat kā bibliotekāram ir jāpārzina grāmatas, lai varētu ieteikt, tas pats jau arī attiecas uz tehnoloğiju jomu.» Vienlaikus diskusijas dalībnieki tika atzinuši, ka nepārtraukta sekošana lỉdzi izmain̄ām tehnoloğiju attīstībā ir izaicinājums bibliotekāriem, kas prasa laiku un piepūli: «Bieži vien bibliotekāriem ir grūti sākumā piennemt tos jaunumus, ir tā pretestība. Un, kad bibliotekāriem pašiem beidzot tas «nosēžas» un tie pieṇem pārmaiņas, tad jaunieši tos zināšanās jau bieži vien ir apsteiguši. Tu komfortabli jūties tajā vecajā, ko tu esi apguvis, un, kad kaut kas jauns ir jāmācās un jāpiespiež sevi, tad tur ir papildus laiks un piepūle vajadzịga.»

BIBLIOTEKĀRU IESPĒjAs UN GATAVĪBA PILDĪT DIGITĀLĀs PRATİBAS MEDIATORU LOMU Nozares pārstāvju diskusijā tika atzīts, un to apstiprināja arī bibliotekāru intervijās iegūtā informācija, ka izpratne un gatavỉba uzṇemties digitālās pratības mediatora lomu nav vienlīdz izteikta visu bibliotēku pārstāvjiem: «Mēs jau gribētu domāt, ka katra mazā bibliotēkā ir kā maza 
gaismas pils, taču ne vienmēr tas tā nostrādā. Taču realitāte ne vienmēr tāda ir. Situācijas ir ḷoti atšḳirīgas.»

Vērtējot savu lomu attiecībā uz to, kā bērni lieto internetu, nereti bibliotekāri tika norādījuši, ka viniem nav zināms bērnu vecāku viedoklis šajā jautājumā: «Mana loma? To es nemaz tā nezinu. Ja kāds atnāk, kas neprot un nav redzējis un sāk no sākuma, tur jau varbūt kaut ko bibliotekārs varētu ko līdzēt. Bet te jau arī vajag zināt vecāku viedokli - vai vecāki grib.»

Izvērtējot savu potenciālo lomu bērnu digitālās kompetences kontekstā, bibliotekāri un arī nozares pārstāvji vienprātīgi atzīst, ka bibliotekāru būtiskākais uzdevums ir iemācìt strādāt ar informāciju: «Meklēt pareizi informāciju par tēmām, apgūt dažādus celvežus, meklēt îsākos celus. Informācijas izvērtēšana. Tas varētu būt tas pamatuzdevums. Jau nedaudz advancētākiem pusaudžiem - praktiskas prasmes - audioapstrāde, videoapstrāde. Dažādas radošãs izpausmes.» Vienlaikus pētijuma rezultāti liecina, ka bērnu un pusaudžu aktivitātes internetā visbiežāk ir saistìtas drizāăk ar izklaidi, parasti ar datorspēlēm un ar socializēšanos sociālajos tîklos, nevis ar informācijas meklēšanu mācību vai pašattīstības vajadzībām. Šādus novērojumus intervijās minējusi lielākā dala bibliotekāru: «Viniem jau tādas intereses nemaz nav. Es gribu teikt - ka uz to, lai kaut ko izzinātu un iemācītos internetā-tur viniiem ir švaki. Interese viṇiem nav. Un es jau nevaru vinuus ierobežot, ko tad es viniem teikšu - ka spēles lai nespēlē, tik ko citu? Uz šejieni jau vinini nāk pārsvarā izklaidēties.»

Gan bibliotekāru intervijās, gan diskusijā dominē viedoklis, ka bibliotekāram būtu jāprot bērniem iemācìt to, ka internetu ir iespējams izmantot ne tikai izklaidei, spēlēm un sazinai sociālajos tikklos: «Bibliotekāriem tomēr būtu jādomā par to, kā to jauno cilvēku ievilkt vairāk no tādām izklaides aktivitātēm uz tādām vairāk produktīvām. No informācijpratības viedokḷa vissvarīgāk bibliotekāram būtu atraisīt bērnam to vēlmi mācìties. Bibliotekāram būtu jāprot uzḳert tās bērnu intereses un parādìt, kā meklēt to, kas viṇam interesants un nepieciešams arī mācībām.»

Nozares pārstāvju diskusijās atkārtoti tika norādīts uz nepieciešamību bibliotēkām digitālās pratības jautājumos sadarboties ar skolām un skolotājiem, veicinot viṇu izpratni par jauno mediju un tehnoloợiju pielietojumu skolās mācību procesā: «Būtu jādomā par to, kā nodrošināt to sakabi starp bibliotēkām un skolām. Diemžēl skolās nereti tiek bremzēta pieeja attiecībā uz interneta resursu izmantošanu, nereti to pat aizliedzot, liekot izmantot tikai mācību grāmatas. Ir sākts praktizēt tādu nodarbību kā mācību stunda bibliotēkā. Skolotāju vietā jau mēs nenostāsimies, bet mēs varam ari parādīt skolotājam, kā viņ̌̌, izmantojot visus šos te kompleksos medijus, var stundu pārradīt savādāku un interesantāku.»

Bibliotekāri ne vienmēr ir pārliecināti par savu lomu un tiesībām attiecībā uz bèrnu sociālo mediju lietojumu bibliotēkās - rodas jautājums, vai vini drīkst kontrolēt šĩs aktivitātes, vai ir jāievēro neitralitāte: «Sarežğîits ir jautājums par sociālo tìklu lietojumu bibliotēkās un to, cik praktiski tur bibliotekārs var iesaistīties. Pornogrāfiju jau uzreiz bibliotekārs var noḳert, bet ar ko bērns sazinās sociālajos tìklos? Pēc idejas jau publisko bibliotēku pakalpojumiem ir jābūt anonīmiem. Principā pēc sava aicinājuma un pārliecības tādu sociālo tỉklu lietojumu jau bibliotekārs nemaz nedrīkst kontrolēt. Bet no otras puses - tie lietotāji taču ir tikai bērni un pusaudži, kuri ir jāuzrauga. Kur ir tas balanss?» Savukārt nozares pārstāvju diskusijās vairākkārt tika norādīts uz nepieciešamību bibliotekāriem apgūt padziḷinātas zināšanas par sociālo mediju darbības pamatprincipiem. Tāpat tika uzsvērts, ka svarīgi būtu bibliotekāriem apgūt prasmes, kas nepieciešamas, lai bibliotekāri paši kḷūtu par advancētākiem sociālo mediju lietotājiem. Pretējā gadijjumā mediācija šajā tik ḷoti nozīmīgajā jomā nav iespējama.

Bibliotekāru atbildes attiecībā uz bērnu interneta lietojuma uzraudzību un kontroli bibliotēkās variē un liecina par atškirīgām pieejām. To apstiprina arī nozares pārstāvju teiktais: «Bibliotekāri ir ḷoti dažādi savās izpratnēs un reakcijās. Reakcijas uz katru konkrēto risku situāciju būs ḷoti dažādas un atškirīgas. Pornogrāfija, vardarbība - tur jau visi aptuveni vienlīdz reaǵēs, bet loti sāpịga ir spēḷu lieta. Bet liela dala bibliotekāru to neuztver kā problēmu. Viṇi ir samierinājušies ar situāciju - nu spēlē tās spēles - ko tu tur padarīsi.» Bibliotekāru interviju rezultāti liecina, ka atškirīgās pieejas ir atkarīgas gan no bibliotekāra izpratnes par savu lomu attiecībā uz šiem procesiem, gan no paša bibliotekāra digitālajām prasmēm un iemañām lietot tehnoloğijas, gan no bibliotekāra laika resursiem. Dala bibliotekāru tikai dažreiz pievērš uzmanību tam, kādas aktivitātes bibliotēkās internetā veic bērni, un bieži bērnu aktivitātes internetā netiek uzraudzītas: «Es viṇiem tā pārlieku klāt nesēžu un neskatos, ko nu katrs te dara. Kādreiz es esmu redzējusi, ka atnāk vēl te kāds un vini tur kopā uzjautrojas, un tad es eju paskatìties, ko tad viṇi tur ir sameklējuši. Kaut ko jau es tur skatos, bet ne vienmēr.»

Nereti bibliotekāriem raksturīga formāla pieeja, atsaucoties uz bibliotēkās pieejamajiem noteikumiem, kas regulē interneta lietojumu bibliotēkās: «Katrai bibliotēkai jau ir savi interneta lietošanas noteikumi, kas arī ir loti svarīgi, kur arī ieraksta galvenos punktus, un tad bibliotekārs cenšas tos kontrolēt.»

Tomēr atsevišķos gadijjumos bibliotekāru atbildes liecina, ka vini intuitīvi veic mediatora pienākumus, skaidrojot interneta lietošanas noteikumus. «Uz sienas ir izlikti noteikumi. Cik nu viṇi ir tos lasijuši-es nezinu! Nedaudz jau es ar viniem piestrādāju, mutiski. Kurš tad ies tos noteikumus lasît! Mēs jau parunājamies nedaudz.»

Diskusijā ar bibliotēkas nozares pārstāvjiem tika norādīts, ka interneta lietojuma drošiba bieži tiek atstāta pašu bērnu un pusaudžu ziña: «Lielā mērā drošỉba tiek atstāta pašu apmeklētāju zinā. Netiek izmantotas 
tehniskas iespējas un filtri, lai kontrolētu un kaut kā ierobežotu. Nupat bija skandāls bibliotēkā, kur bērni bija skatijušises pornogrāfiju, bet bibliotekāra atbilde bija - ir taču noteikumi, un noteikumos tas nav atḷauts. Viss ir uz pašu bērnu sirdsapzinas.» Šì situācija kontrastē ar bērnu vecāku priekšstatu par bibliotēku kā respektablu un drošu vietu, kur bērniem uzturēties: «Vecāki domā, ka, laižot bērnus uz bibliotēku, viṇi laiž viṇus uz drošu saliṇu, un pēkšņi nokonstatē, ka vini tur skatās pornogrāfiju, jo datoriem nav filtru.»

Pētijuma rezultāti liecina, ka, pateicoties bibliotēkās nodrošinātajai Wi-Fi pieejamībai, arvien biežāk bērni bibliotēkās vai to tuvumā internetu izmanto ne vien bibliotēku stacionārajos datoros, bet arī savās vai draugu mobilajās ierīcēs. Saskanā ar bibliotēku nozares pārstāvju teikto: «Šobrīd vairs bērni neizmanto tik daudz internetu publiskajās bibliotēkās, tas ir retāk, kā tas bija agrāk. Viṇi nāk uz bibliotēkām ar saviem telefoniem un savām planšetēm. Daudzas bibliotēkas ir atbrīvojušas telpas no novecojušiem datoriem, izmanto interaktīvās sienas. Vairs netiek izmantoti novecojušie datori, bet joprojām tiek izmantota bibliotēkas infrastruktūra, kas piedāvā bezvadu internetu.» Šo procesu ietekme parasti ir ārpus bibliotekāru uzraudzības, un bibliotekāriem nav skaidra priekšstata par savu lomu to uzraudzībā, kā arī mulsumu šajā jomā rada fakts, ka jauno tehnoloğiju lietojuma prasmes un iemaṇas bieži bibliotekāriem ir ievērojami zemākas nekā bērniem un pusaudžiem. Kā liecina diskusijā dzirdētais - būtiskās izmainas tehnoloğiju lietojumā ir ienesušas nepieciešamību pēc pilnīgi jaunām pieejām bibliotekāru darbāa ar bērniem un jauniešiem.

\section{Secinājum}

Informācijas un komunikācijas tehnoloǵiju attīstỉbas rezultātā ikvienam rodas nepieciešamība pēc jaunu zināšanu un prasmju - digitālās pratības - apguves. Bibliotēkas kā demokrātiskas sabiedrỉbas institūcijas vienmēr centušās nodrošināt neformālās izglìtỉbas iespējas par sabiedrībā aktuāliem jautājumiem. Digitālās pratības apguves atbalsts bibliotēkās nozìmē, ka bibliotekāriem parādās jauni uzdevumi - gan pašiem apgūt jaunās prasmes, gan apmācīt citus, kas savukārt nozīmē gan inovācijas profesijā, gan iespēju piedāvāt jaunus pakalpojumus (no evolucionāriem lỉdz revolucionāriem jauninājumiem). Latvijas atškirīgā situācija attiecībā uz to, kā bērni un jaunieši publiskajās bibliotēkās izmanto internetu, bibliotekāriem vēl rada papildu lomu - būt par mediatoriem digitālajā pratībā tieši šai lietotāju grupai. Darbs ar bērniem un jauniešiem bibliotēku darba laukā ir sen attīstita joma, taču būt par digitālās pratības mediatoriem ir nopietns izaicinājums.

Pētỉjuma datu analīze rāda, ka bibliotekāriem ir zems pašvērtējums attiecībā uz vairākām digitālajām prasmēm, jo ỉpaši IKT lietojumu. Nozīmīgākie škēeššli, kas bibliotekāriem kavē veiksmīgi apgūt un ìstenot jauno - digitālās pratības mediatora-lomu, saistīti ar to, ka IKT lietošanas prasmès bèrni un jaunieši bieži vien ir kompetentāki kā pieauguušie, un tas nereti bibliotekāros rada kauna un neprofesionalitātes sajūtu. Kā jau minēts, lielākoties šāda pašvērtējuma iemesls ir pienēmums, ka bērni ir tehnoloğiski advancētāki nekā bibliotekāri, un to tikai veicina fakts, ka dažādas tehnologiju ierīces (viedtālruṇi, planšetdatori) jaunajai paaudzei kḷuvušas pašsaprotamas un bērnu un jauniešu dzīvē ieṇēmušas rotaḷlietu vietu un aizstājušas citas brīvā laika pavadī̌anas iespējas.

Pašvērtējuma atšḳirības vērojamas atkarībā no digitālās aktivitātes specifikas. Ja bibliotekāri jūtas kompetenti, augstu vērtē savas digitālās prasmes informācijas meklēšanā un ir gatavi pildīt digitālā mediatora lomu attiecībā uz šo funkciju, tad nelabvēlīgāka situācija ir saistībā ar potenciālo mediāciju sociālo tīklu lietojumā, bet, jo īpaši-datorspēlu lietojumā. Izaicinājums bibliotekāriem būt mediatoriem digitālajā pratībā tas ir arī tāpēc, ka digitālā vide ir strauji mainīga, ir nepieciešams regulāri sekot lïdzi jaunajām tehnoloğijām un to iespējām. Informācijas un komunikācijas tehnolog̣iju u.c. digitālo prasmju apguvei būtu jākḷūst par regulāru profesionālo kompetenču attīstības lauku, taču ne vienmēr, esot aiznemtiem ar ikdienas pamatpienākumu veikšanu, bibliotekāriem ir iespējams veltìt tam laiku.

Analīzes rezultāti liecina, ka bibliotekāru pašvērtējums par savām digitālajām prasmēm ir atškirīgs - augstāks pašvērtējums vērojams bibliotekāriem, kas strādā pilsētās, attiecīgi lauku reǵionos bibliotekāri ar dažiem izṇēmumiem ir kritiskāki. Tomēr kopumā pētijuma rezultāti liecina, ka bibliotekāri apzinās informācijas un komunikācijas ieriču lietošanas prasmju nepieciešamību, kā arī spēj novērtēt savu prasmju vājās vietas (piemēram, radišanas prasmes (tekstu, video ierakstu veidošanu un publicēšanu tīmeklī), vairāku tehnolog̣isko prasmju trūkumu, kā arī zināšanu nepilnības informācijas izmantošanas tiesību jautājumos. Tātad var secināt, ka bibliotekār ir gatavi uzṇemties jaunās lomas, bet arī apzinās, ka tām vēl nepieciešama sagatavošanās (mācīšanās).

\section{Izmantotie avo}

Addison, C., \& Meyers, E. (2013). Perspectives on information literacy: a framework for conceptual understanding. Information Research, 18(3). Retrieved from www.informationr.net/ir/18-3/colis/paperC27

Aldrich, S., \& Keller J. (2013). The Librarian in 2020. Reinventing Libraries. Retrieved from http://lj.libraryjournal.com/2013/10/future-of-libraries/the-librarianin-202O-reinventing-libraries/\#

Brikse, I., Freibergs, V., \& Spurava, G. (2014). Children's internet competence vs. self-confidence and self-comfort: case study of Latvia. In S. Kurbanogly, 
S. Špiranec, R. Catts, E. Grassian, D. Micrachi (Eds.), European Conference on Information Literacy (2nd). Springer.

Brikse, I., \& Spurava, G. (2014). Kids online - safety and risks: full findings from children survey of 9- to 16-year-olds in Latvia. Retrieved from http://eprints. lse.ac.uk/60574/

Centrālā statistikas pārvalde (2016). Bērni Latvijā. Izgūts no http://www.csb.gov.lv/ sites/default/files/nr_12_berni_latvija_2016_16_oo_lv_en.pdf

Digital intelligence (n.d.). Retrieved from https://www.dqinstitute.org/

European Commission (2007). Digital Literacy: Skills for the Information Society Retrieved from http://ec.europa.eu/information_society/tl/edutra/skills/ index_en.htm

Gilster, P. (1999). Digital Literacy. New York: John Wiley \& Sons.

IDEO (2015). Design thinking for libraries: A toolkit for patron-centered design. Retrieved from designthinkingforlibraries.com/

IFLA Statement on Digital Literacy (2017). Retrieved from https://www.ifla.org/ publications/node/11586

JISC (2014). Developing digital literacies: Provides ideas and resources to inspire the strategic development of digital literacies - those capabilities which support living, learning and working in a digital society. Retrieved from https://www. jisc.ac.uk/guides/developing-digital-literacies

Kalmus, V. (2013). Children's safety in the new media environment. In M. Heidmet (Ed.), Estonian Human Development Report 2012/2013: Estonia in the World (pp.92-94). Tallinn: Estonian Cooperation Assembly. Retrieved from http:// www.kogu.ee/wp-content/uploads/2013/05/EIA2013_eng.pdf

Kalmus, V., von Feilitzen, C., Siibak, A. (2012). Effectiveness of teachers' and peers' mediation in supporting opportunities and reducing risks online. In S. Livingstone, L. Haddon, \& A. Görzig (Eds.), Children, risk and safety on the internet: Research and policy challenges in comparative perspective (pp. 245256). Bristol: Policy Press.

Kwanya, T., Stilwell, C., \& Underwood, P. G. (2012). Intelligent libraries and apomediators: Distinguishing between Library 3.0 and Library 2.0. Journal of Librarianhip and Information Science, 45(3), pp.187-197. https://doi. org/10.1177/0961000611435256

Latvijas publiskās bibliotēkas un internets: tehnoloğijas, pakalpojumi un ietekme (2013). Bibliotekāru aptauja / Pētījumu centrs SKDS. Izoūts no http://www.kis. gov.lv/agentura/petijumi/

Livingstone, S. (n. d.). EU Kids Online: Findings, methods, recommendations. Retrieved from https://lsedesignunit.com/EUKidsOnline/html5/index. html?page $=1$ \&noflash

MORI (2015). Basic digital skills: UK Report 2015. Retrieved from https://goon-uk-prod.sz-eu-west-1.amazonaws.com/uploads/ Basic\%20Digital\%20Skills_UK\%2OReport\%2O2015_131015_FINAL. pdf?utm source=about heatmap page\&utm medium=bds_research\&utm campaign=bds_research_about_heatmap_page

Park, Y. (2016). 8 digital skills we must teach our children. Retrieved from https:// www.weforum.org/agenda/2016/o6/8-digital-skills-we-must-teach-ourchildren/

Romero, M. (2014). Digital literacy for parents of 21 st century children. Retrieved from https://www.openeducationeuropa.eu/sites/default/files/legacy_files/ asset/Digital Literacies and eCompetence In depth 38 3 3 1.pdf

Social Innovations (n. d.). Retrieved from http://www.transitsocialinnovation.eu/ theme/social-innovation

Stordy, P. H. (2015). Taxonomy of literacies. Journal of Documentation, 71, 3, pp. 456-476. http://dx.doi.org/10.1108/JD-10-2013-0128

UNESCO (2013). Global Media and Information Literacy Assessment Framework: Country Readiness and Competencies. Retrieved from http://www.unesco. org/new/en/communicationand-information/resources/publicationsandcommunication-materials/publications/fulllist/global-media-andinformation-literacyassessment-framework

Valsts ağentūra «Kultūras informācijas sistēmas» (2008). Publisko bibliotēku attīstības projekts. Izgūts no http://www.3td.lv/index.php/lv/par/apraksts/

Vassilakaki, E., \& Moniarou-Papaconstantinou, V. (2015). A systematic literature review informing library and information professionals' emerging roles. New Library World, 116, 1/2, pp. 37-66. http://dx.doi.org/10.1108/NLW-o5-20140060 


\section{BAIBA BELA, DR. SC. SOC.}

Latvijas Universitātes Sociālo zinātṇu fakultātes Sociolog̣ijas nodalas asociētā profesore, Sociālo un politisko pētỉjumu institūta vadošā pētniece. Pētnieciskās intereses: ilgtspējiga attīstỉba, sociālā politika, nabadzība un sociālā atstumtība, migrācija, identitāte.

\section{BAIBA HOLMA, DR. PHILOL.}

Latvijas Universitātes Sociālo zinātnu fakultātes Informācijas un bibliotēku studiju nodaḷas asociētā profesore, Sociālo un politisko pētijumu institūta vadošā pētniece. Pētnieciskās intereses: informācijpratība, medijpratība, digitālā pratība.

\section{ANITA KOVALLEVSKA, MG. IUR.}

Latvijas Universitātes Juridiskās fakultātes Valststiesību zinātṇu katedras lektore, tiesnese. Pētnieciskās intereses: sociāli atbildīgas valsts princips, tiesības uz sociālo nodrošinājumu.

\section{MAREKS NIKLASS, DR. SC. SOC.}

Latvijas Universitātes Sociālo zinātṇu fakultātes Socioloğijas nodaḷas docents, Sociālo un politisko pētỉjumu institūta pētnieks. Pētnieciskās intereses: nodarbinātības politika, darba tirgus apsteidzošie pārkārtojumi, sociālā nevienlīdzība, strādājošo nabadziba.

\section{JURIJS NIKIŠINS, DR.SC.SOC.}

Latvijas Universitātes Sociālo zinātṇu fakultātes Socioloğijas nodalas docents, Sociālo un politisko pētijumu institūta pētnieks. Pētnieciskās intereses: ilstspējịga attīstība, nabadzỉba un sociālā atstumtība, politiskās vērtības un attieksmes, pilsoniskā lỉdzdalība.

\section{JĀNIS PLEPS, DR. IUR.}

Latvijas Universitātes Juridiskās fakultātes docents, Tiesību teorijas un vēstures katedras vadītājs, Valsts prezidenta konstitucionālo tiesību padomnieks. Pētnieciskās intereses: tiesību teorija un vēsture, konstitucionālās tiesības.

\section{LITGA RASNAČA, DR. SC. SOC.}

Latvijas Universitātes Sociālo zinātnu fakultātes Socioloğijas nodalas asociètā profesore, Sociālo un politisko pētỉjumu institūta vadošā pētniece. Pētnieciskās intereses: sociālā politika, sociālā atstumtība, mājokḷu politika, sociālā darba organizācija.

\section{IVETA REINHOLDE, DR.SC. POL.}

Latvijas Universitātes Sociālo zinātṇu fakultātes Politikas zinātnes nodaḷas asociētā profesore, Sociālo un politisko pētijumu institūta vadošā pētniece. Pētnieciskās intereses: pārvaldība, administratīvās reformas, pārvaldes līmenu attiecības.

VINETA SILKĀNE, MG. PSYCH., MG. MATH.

Latvijas Universitātes Sociālo zinātnu fakultātes Sociālo un politisko pētỉjumu institūta zinātniskā asistente, Vidzemes Augstskolas lektore. Pētnieciskās intereses: sociālā izziṇa, ekonomikas psiholoğija, veselības uzvedỉba.

\section{GUNA SPURAVA, MG.SC.SOC.}

Latvijas Universitātes Sociālo zinātnu fakultātes Sociālo un politisko pētỉjumu institūta zinātniskā asistente, Latvijas Universitātes Sociālo zinātṇu fakultātes Komunikācijas studiju nodąlas lektore. Pētnieciskās intereses: jaunās paaudzes mediju lietojums, medijpratība, mediju industrijas un mediju ekonomika.

\section{MARTA TRIPĀNE, DR. SC. POL.}

Pētnieka p.i. Latvijas Universitātes Sociālo zinātnu fakultātes Sociālo un politisko pētijumu institūtā. Pētnieciskās intereses: publiskā pārvalde, laba un vieda pārvaldība, uz evidencēm balstīta rīibpolitika, veselïbas rīcibpolitika.

\section{ANETE VINGRE, DR. SC. POL.}

Zinātniskā asistente Latvijas Universitātes Sociālo zinātṇu fakultātes Sociālo un politisko pētījumu institūtā. Pētnieciskās intereses: zinātnes, tehnolog̣iju un inovācijas rīcībpolitika, sociālās inovācijas, rīcībpolitikas izvērtēšana. 


\section{Sustainable development, reduction of poverty and inequality, and a decent life}

Latvia has been an independent country for more than 25 years, during which we have seen establishment and strengthening of fundamental freedoms like freedom of speech, freedom of assembly, freedom of movement and other important developments. Our daily material well-being substantially differs from that of the early 1990s. Soviet-era commodity shortage now exists only in stories, reminiscing on queuing for butter, sugar or vouchers for purchasing spirits. The younger generation has grown up in Latvia, where a special permission is no longer needed to visit Cape Kolka, no visa required to travel to France, and they have not seen the empty store shelves. At the same time, there still is a tendency to focus on things not achieved, instead of concentrating on accomplishments, psychologically continuing to think along the lines of "catching up with the West". Statistical data show that, on the scale of the European Union (hereinafterthe EU), wages and pensions in Latvia are lower, income inequality is higher, the social budget and the health budget (percentage points of GDP) are lagging behind the EU average. The store shelves are full, however, not everyone can afford to buy even the essentials. The consumer society's industrial art works in luxury stores sharply remind of the purchasing power shortage characteristic to most of the consumers. Looking at the standard of daily living in Denmark, Germany or Ireland, there is a clear sense that in terms of living standards we still fall behind the aspired level of prosperity.

The book is dedicated to economic and social development processes in Latvia from the perspective of sustainable development. The approach advocates every person's right to decent life, ensured by economic development which is in balance with ecosystem of our planet. Already in 1995, at the United Nations World Summit for Social Development, it was emphasized that humanity and prosperity should be at the centre of development for all (United Nations, 1995). The research team of National Research Programme "Innovation and sustainable development: Latvia's post-crisis experience in a global context" (SUSTINNO) project "Social dimension of sustainability and social innovation" explored the social issues of sustainable development, while the economic and environmental dimension was researched by the colleagues in other SUSTINNO projects. Taking into account the depth of the 2008-2009 economic crisis and the recognition that the social consequences of the crisis are more pronounced than in economic matters (Brigsa et al., 2014), the aim posed by the team of researchers was even more focussed-exploring the post-crisis development trajectories. The collective monograph concluding the project introduces the main results of this research. First and foremost, the summary describes the ideas pertaining to sustainable development, which form the conceptual basis of the study, followed by a summary of the chapters. The structure of the book revolves around three major research questions: what is the legal framework and the 
effectiveness of governance for ensuring sustainable development in Latvia, the progress in eliminating the main obstacles in the path of sustainable social development - poverty and inequality, and the possibilities of social innovation in solving new development challenges and social problems.

We are living in an increasingly complex world, wherein both local and national development is increasingly tied on the global scale. The global context of the study is formed by the tension between environmental and societal needs, as well as the disagreement between science and politics in understanding development, the nature of sustainability and the framework for a decent life for all. At present, the world's leading researchers in sustainable development advance two very important questions - how to balance people's desire to live better with the boundaries of the planet's ecosystem and how to create a fairer society that is less unequal, and where each individual has an opportunity to pursue the goals important to himself or herself without seriously compromising the future generations' opportunities to implement their goals (United Nations Development Programme, 2011). It is also a question of our responsibility to the next generations - whether our great-grandchildren will also have a decent life and what it will be like, both in terms of natural resources and the environment, as well as the structure of society and interrelationships of people, which we leave to the future generations. The United Nations and the affiliated researchers are currently the most powerful lobbyists advocating for the idea that "Human development is the expansion of people's freedoms to live long, healthy and creative lives; to advance other goals they have reason to value; and to engage actively in shaping development equitably and sustainably on a shared planet" (United Nations Development Programme, 2010, p. 2). In this perspective, poverty and inequality are the key factors that prevent people from being free from hunger, illiteracy, avoidable ailments. Most importantly, poverty and inequality restrict the positive freedom to live with dignity and to set and achieve the personally important goals.

The right to decent life to be ensured by sustainable development is an essential topic continued throughout the book. The wording of the United Nations Environment and Development Conference's Report "Our Common Future" is more generally known both internationally and in Latvia: Sustainable development is development that meets the needs of the present without compromising the ability of future generations to meet their own needs (WCED, 1987). The present study was guided by the latest approach that puts the ideas of prosperity and freedom in the forefront. Amartya Sen, the prominent economist, proposes to look at development as strengthening people's capabilities and freedoms rather than just satisfying needs (Sen, 2001; 2013). He believes that humans should not be seen only in the dimension of our needs (because our needs are similar to those of all the other living beings), but also in our freedom to decide what we want (including the decision what needs to satisfy), and our freedom to live the way we want (regardless of whether the chosen lifestyle is viewed as a need).

The backbone of the SUSTINNO study is formed by the assumption that people have the right to live a long, healthy and creative life, during which they can fulfil the goals important to themselves and that the realization of these goals should not restrict the ability of future generations to set and fulfil their goals. Analyzing the current processes in Latvian society, the book is developed as a platform for further public discussion of the values that support the development of the country and its progress towards the set development goals. The following issues have been raised in the study: what are the post-crisis social problems in Latvia and their impact on sustainable social and regional development, the possibilities of surmounting the social problems, and what are the obligations stipulated by the legal framework for ensuring sustainable development, and the ability of the governance system to resolve the social problems (SUSTINNO, 2014).

The first part of the collective monograph, "Legal and Governance Aspects of Sustainable Development" addresses the responsibilities defined in the legal framework for ensuring sustainable development and the ability of the governance system to address social problems effectively. JĀNIS PLEPS in his article "Constitutional Dimension of Sustainable DevelopMENT" investigates whether the Republic of Latvia Constitution Satversme contains a sufficient regulation of sustainable development issues and what type of action in this area is envisaged by the Satversme. The author analyzes the development of the principle of sustainable development in the constitutional system of Latvia, as well as examines the norms of the Satversme containing certain elements pertaining to the principle of sustainable development. Given that the principles of human dignity, justice, equality and solidarity play a decisive role in the social dimension of sustainable development, attention is also drawn to the question of social responsibility of the state. ANita Kovalievska in her article "Principle of a Socially ResPONSIBLE STATE AS A PRINCIPLE CHARACTERISTIC TO THE REPUbliC OF LATVia STATE SySTEM" introduces the historical development of the idea of a socially responsible state in the world and Latvia, analyzes the conten of the principle of a socially responsible state (the state's duty to ensure the minimum preconditions for the dignified existence of a person; the duty of the state to ensure protection in the case of social risk; the state's duty to foster social justice and human affiliation with society), as well as explains the obligations and rights of the Republic of Latvia arising from this principle. IVETA REINHOLDE in her article "Governance of Social Policy: CHALLENGES AND LESSONS LEARNED" analyzes the social policy planning documents currently in force in Latvia - the guidelines, to identify the vision of 
social sphere and services management exposed therein. In her turn, MARTA Tripāne in her article "Health Inequality and Health Policy in LATVIA" views the inequalities identified in the self-assessment of health condition and the factors affecting thereof, as well as compares the priorities defined by the population with the priorities in health policy.

The second part of the monograph "Towards A Decent Life" contains the analysis of poverty and social exclusion as prominent social problems in Latvia, highlighting their negative impact on sustainable social and regional development. BAIBA BELA and JURIJS N̦iKišIns in the article "SOCIAL Dimension of Sustainability: Are We Moving Towards Prosperity AND DECENT LIFE?" examine the evolvement of post-crisis development trajectories in accordance with the state's long-term development priority-reducing income inequality and poverty risks, and promoting social inclusion and formation of a middle class. The authors discuss the issues of poverty and social exclusion in the regional dimension of Latvia, the methodology for measuring these social problems. Through an in-depth analysis of material deprivation of households, the authors build a discussion of the residents' ability to achieve a decent standard of living as an important factor of social sustainability. BAIBA BELA in her article "DEAD END OF POVERty: ACcumulation of Difficulties and Pursuit of Solutions in WOMEN's STORIES" focuses on analyzing the experience of a social group that is particularly vulnerable and subject to poverty - women with low-education level who bring up children alone or with difficult partners. The author explores the meaning of life in the circumstances of limited resources in consumer society. In both articles, the authors also touch upon the differences between cities and rural areas in terms of living standards, opportunities and accessible services, and also discuss problem-solving opportunities. It should be noted that the social problems of in-work poverty and housing accessibility will be addressed by project researchers Mareks Niklass and Liga Rasnača in a separate edition.

The third part of the monograph, "Social Innovations for a Better Life", looks at the role of the state in promoting innovation, and more profoundly explores two very different examples of social innovation, each in its own way relating to human securitability and quality of life. ANETE VINGRE in the article "Social InNovations: Role of State in Their Promotion GLOBALLY AND IN LATVIA" introduces the discussion about the role of the state in promoting social innovations, analyzes the international experience in relation to the policy instruments used by the countries to promote social innovations, as well as provides an insight into the situation in Latvia. VINETA Silkāne in her article "Application of Nudging to Promote PaRTiCiPATION IN CANCER EARLY DETECTION PRogramme” addresses a range of social innovations related to health behaviour. The author investigates what kind of inducements would promote the health check attendance by the invitees. The issue is relevant to the people's health securitability - given the high mortality rates caused by oncologic diseases (and the fact that toda oncologic diseases can be successfully treated), on the one hand, and the low response of citizens to participation in the nationally funded cancer screening programme on the other. Baiba Holma and Guna SPURAVA in their article "Role of LibraRian as a MEdiator in Promoting DigiTAL Literacy of CHILDREN AND Young PEOPLE" explore the opportunities for improving information literacy and particularly the digital literacy in children and young people by focusing on librarians, since children and teenagers in Latvia use the Internet in libraries much more frequently than elsewhere in Europe. Taking into account the lack of digital literacy mediation by parents and educators, the authors investigate, whether librarians in public libraries are potentially capable of fulfilling new social roles regarding the development of children's and youth digital literacy.

\section{Acknowledgements}

In acknowledgment of all those who have supported us throughout the research process and the book during the creation process, we would like to express our particular gratitude to the Ministry of Education and Science for funding the state research programme, enabling us to conduct the research, to the administration of the University of Latvia Faculty of Social Sciences for it extensive support in solving all the practical and financial issues, to Market and Social Research Centre "Latvijas Fakti", which in 2015 carried out a quantitative study "Sociological Survey on the Risks of Poverty and Social Exclusion". We would like to thank the students of the Sociology Master's programme and the students of the Culture and Social Anthropology Bachelor's programme, who in 2015 and 2016 conducted the life story interviews with people who experienced difficult living conditions, and entrusted the SUS TINNO study with 25 interviews. We also express our appreciation of the meticulous work carried out by publishing house "University of Latvia Press", bringing the book to its readers.

\section{Sources}

Brigsa, S., Broka, A., Rajevska, F., Ročāns, K., Romanovska, L. \& Ziverte, L. (2014) Krīze: izaicinājumi un iespējas sociālajai cilvēkdrošǐbai Latvijā [Crisis: Challenges and Opportunities for Social Securitability]. In: J. Rozenvalds, \& A. Zobena (Eds.), Daudzveidīgàs un mainīgàs Latvijas identitātes [Varied and Changing Identities of Latvia]. Rīga: LU Akadēmiskais apgāds, pp.149-172. 
Sen, A. (2013). The Ends and Means of Sustainability. Journal of Human Development and Capabilities: A Multi-DisciplinaryJournal for People-Centered

Development, 14(1), pp.6-20. doi:10.1080/19452829.2012.747492

United Nations (1995). Gateway to Social Policy and Development. Report of the

World Summit for Social Development. A/CONF.166/9, Reprot adapted by UN

Department of Economic and Social Affairs on 6-12 March 1995. Retrieved

from http://www.un.org/esa/socdev/wssd/text-version/agreements/

poach $2 . h$ tm

United Nations Development Programme (2010). The Real Wealth of Nations:

Pathways to Human Development. Human Development Report. New York:

United Nations Development Programme. Retrieved from http://hdr.undp. org/en/reports/global/hdr2010/chapters/

United Nations Development Programme (2011). Sustainability and Equity: A Better Future for All. Human Development Report. New York: United Nations

Development Programme. Retrieved from http://hdr.undp.org/en/reports/ global/hdr2011/download/

WCED (1987). Report of the World Commission on Environment and Development: Our Common Future. Oxford, UK: Oxford University Press. Retrieved from www. un-documents.net/our-common-future.pdf 


\section{BAIBA BELA, DR. SC.SOC.}

Associate professor at the Department of Sociology, Senior researcher at the Advanced Social and Political Research Institute (ASPRI), Faculty of Social Sciences, University of Latvia. Research interests: sustainable development, social policy, poverty and social exclusion, migration, identity.

\section{BAIBA HOLMA, DR. PHILOI.}

Associate professor at the Department of Information and Library Studies, Senior researcher at the Advanced Social and Political Research Institute (ASPRI), Faculty of Social Sciences, University of Latvia. Research interests: information literacy, media literacy, digital literacy.

\section{ANITA KOVALEVSKA, MSC IN LAW}

University of Latvia. Lecturer at the Department of Constitutional and Administrative Law, Faculty of Law, University of Latvia, judge. Research interests: welfare state as a principle of law, right to social security.

\section{MAREKS NIKLASS, DR. SC. SOC.}

Docent at the Faculty of Social Sciences, University of Latvia, Researcher at the Advanced Social and Political Research Institute. Research interests: employment policies, labour market anticipation measures, social inequality, in-work poverty.

\section{JURIJS N̦IKIŠINS, DR. SC. SOC.}

Assistant professor at the Department of Sociology, Researcher at the Advanced Social and Political Research Institute (ASPRI), Faculty of Social Sciences, University of Latvia. Research interests: sustainable development, poverty and social exclusion, political values and attitudes, civic participation.

\section{JĀNIS PLEPS, DR. IUR.}

Assistant Professor at the Faculty of Law of the University of Latvia, Head of the Department of Legal Theory and History, Adviser for Constitutional Affairs to the President. Research interests: legal theory and history, constitutional law.

\section{LİGA RASNAČA, DR. SC. SOC.}

Associate professor at the Department of Sociology, Senior

researcher at the Advanced Social and Political Research Institute
(ASPRI), Faculty of Social Sciences, University of Latvia. Research interests: social policy, social work organization, social welfare, social justice and regional inequality.

IVETA REINHOLDE, DR.SC. POL.

Associate professor at the Department of Political Science, Senior researcher at the Advanced Social and Political Research Institute (ASPRI), Faculty of Social Sciences, University of Latvia. Research interests: governance, administrative reforms, relations between governance levels.

VINETA SILKĀNE, MPSYCH, MMATH, PHD CANDIDATE

Scientific assistant at the Advanced Social and Political Research Institute, Faculty of Social Sciences, University of Latvia, lecturer at the Vidzeme University of Applied Sciences. Research interests: social judgment, behavioral economics, health behavior.

\section{GUNA SPURAVA, MG.SC. SOC., PHD CANDIDATE}

Scientific assistant at the Advanced Social and Political Research Institute, Faculty of Social Sciences, University of Latvia, Lecturer at the Department of Communication Sciences, Faculty of Social Sciences, University of Latvia. Research interests: media use of young generation, media literacy, media industries and media economy.

\section{MARTA TRIPĀNE, DR. SC. POL.}

Researcher at the Advanced Social and Political Research Institute (ASPRI), Faculty of Social Sciences, University of Latvia. Research interests: public administration, good and smart governance, evidence based policy, health policy.

\section{ANETE VINGRE, DR. SC. POL.}

Research assistant at the Advanced Social and Political Research Institute (ASPRI), Faculty of Social Sciences, University of Latvia Research interests: science, technology and innovation policy, social innovation, policy evaluation. 
Grāmatas dizainu un maketu izveidojis Aleksejs

Muraško. Teksta salikumā izmantoti burtveidol

FF Casus Pro (Jevgeniijs Jukečevs, Berline) un

FF Scala Sans Pro (Martins Majors, Arnema).

Grāmata iespiesta un iesieta Jelgavas tipograāfijā. Papirs iekšlapām: Munken Print Cream $1590 \mathrm{~g} / \mathrm{m}^{2}$

(Arctic Paper, Zviedrija); papirs vãkam: Materica

Acqua $250 \mathrm{~g} / \mathrm{m}^{2}$ (Fedrigoni, Itālija).
Ilgtspējiga attīstỉba un sociālās inovācijas

LU Akadēmiskais apgād

Aspazijas bulvāris 5-132, Rīga, LV-105○

apgads@lu.lv·Mājaslapa: www.lu.lv/apgads/

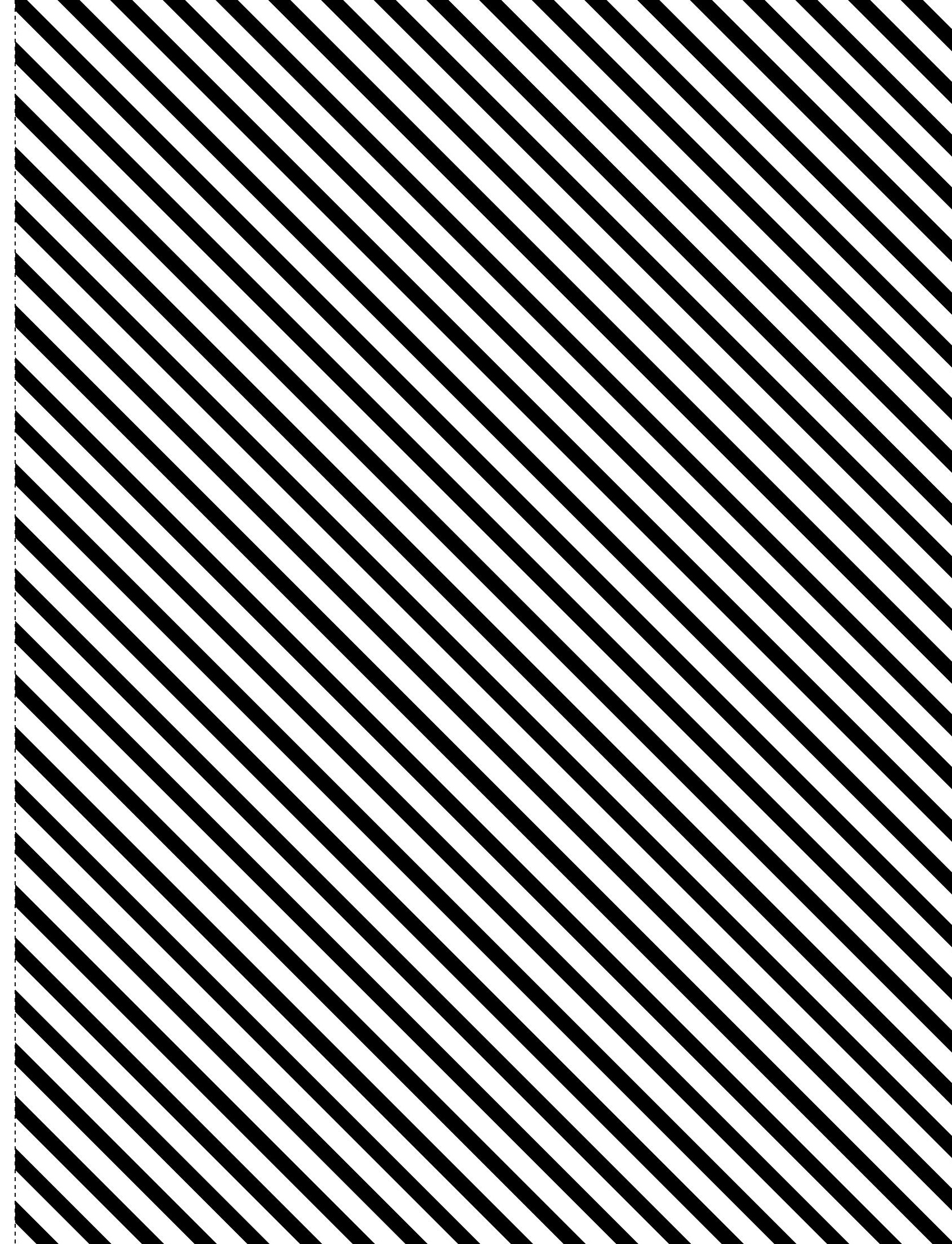


Kolektīvā monogrāfija «Ilghtspējiga attīstība un sociālās inovācijas» apkopo Valsts pētijumu programmas «Inovācija un ilgtspējiga attīstība: Latvijas pēckrīzes procesi globālā kontekstā» (SUSTINNO) ietvaros realizētā pētijumu projekta «Ilgtspējiggas attīstības sociālā dimensija un sociālās inovācijas» galvenās atziņas. Šis projekts tika isstenots Latvijas Universitātes Sociālo zinātnu fakultātes Sociālo un politisko pētijumu institūtā laikā no 2014. līdz 2017. gadam.

Ilgtspējigu attistību virza vizija par labāku pasauli tagad un arī nākamajām paaudzēm. Ilgtspējigas attīstỉbas sociālā dimensija ir cieši saistīta ar nabadzības samazināšanu un vienlïdzịgu iespēju nodrošināšanu visiem iedzivotājiem, lai ḷautu katram īstenot savu potenciālu un piedalīties kopējās labklājības celšanā.

Dažādu sociālo zinātṇu nozaru pētnieku kopdarbs veidots ap trim lielajiem pētijuma jautājumiem: kāds ir juridiskais ietvars un pārvaldes efektivitāte, lai nodrošinātu ilgtspējigu attīstỉbu; kā veicas ar nabadzỉbas un nevienlīdzïbas mazināšanu, kas ir ilgtspējigas sociālās attīstības galvenie kavētāji; kādas ir sociālo inovāciju iespējas jaunu attīstības izaicinājumu un sociālo problēmu risināšanā.

ISBN 978-9934-18-306-5

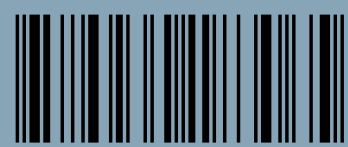

